\title{
Anglo-German Press Attitudes in the Field of European Integration: 1989-2005
}

\author{
by
}

\section{Daniel Armstrong}

A thesis submitted to the Faculty of Graduate and Postdoctoral Affairs in partial fulfillment of the requirements for the degree of

\section{Master of Arts}

in

European, Russian, and Eurasian Studies

Carleton University

Ottawa, Ontario

(C) 2010, Daniel Armstrong 
Library and Archives

Canada

Published Heritage

Branch

395 Wellington Street

Ottawa ON K1A ON4

Canada
Bibliothèque et

Archives Canada

Direction du

Patrimoine de l'édition

395 , rue Wellington

Ottawa ON K1A ON4

Canada
Your file Votre référence

ISBN: 978-0-494-79572-9

Our file Notre référence

ISBN: 978-0-494-79572-9
NOTICE:

The author has granted a nonexclusive license allowing Library and Archives Canada to reproduce, publish, archive, preserve, conserve, communicate to the public by telecommunication or on the Internet, loan, distribute and sell theses worldwide, for commercial or noncommercial purposes, in microform, paper, electronic and/or any other formats.

The author retains copyright ownership and moral rights in this thesis. Neither the thesis nor substantial extracts from it may be printed or otherwise reproduced without the author's permission.
AVIS:

L'auteur a accordé une licence non exclusive permettant à la Bibliothèque et Archives Canada de reproduire, publier, archiver, sauvegarder, conserver, transmettre au public par télécommunication ou par l'Internet, prêter, distribuer et vendre des thèses partout dans le monde, à des fins commerciales ou autres, sur support microforme, papier, électronique et/ou autres formats.

L'auteur conserve la propriété du droit d'auteur et des droits moraux qui protège cette thèse. $\mathrm{Ni}$ la thèse ni des extraits substantiels de celle-ci ne doivent être imprimés ou autrement reproduits sans son autorisation.
In compliance with the Canadian Privacy Act some supporting forms may have been removed from this thesis.

While these forms may be included in the document page count, their removal does not represent any loss of content from the thesis.
Conformément à la loi canadienne sur la protection de la vie privée, quelques formulaires secondaires ont été enlevés de cette thèse.

Bien que ces formulaires aient inclus dans la pagination, il n'y aura aucun contenu manquant. 


\begin{abstract}
British press attitudes regarding Germany are well documented in the early twentieth century and a number of assumptions generally exist about their nature. However, little has been written about attitudes in the postwar era, or about press attitudes in Germany in general. Beyond testing existing assumptions and providing new data, examining press attitudes also provides insight into a nation's psyche and how it constructs images of other nations. This thesis focuses specifically on British and German press attitudes regarding each other in the European integration process, through an examination of five national newspapers from each country. It concludes that existing assumptions about British press attitudes are generally correct, and finds that similar negative undercurrents exist in the German press. The press in each country is further shown to be engaged in constructing and maintaining negative images of the other, which provides broader insight into national attitude formation and identity construction.
\end{abstract}




\section{Acknowledgements}

I wish to thank all faculty members and support staff in the Department of European, Russian, and Eurasian Studies who provided their assistance while I was writing this thesis, and also my student colleagues in EURUS who provided helpful insight and support. Special thanks go to Professor James Casteel, who acted as my advisor, and to Professor Y. Aleksandra Bennett, for her patience and willingness to accommodate me in her busy schedule. 


\section{Table of Contents}

\section{Introduction:}

The British and the Germans

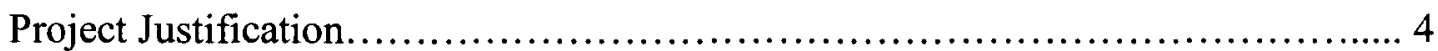

Background Information.................................................... 8

Project Goal and Scope........................................................ 10

Sources and Methodology......................................................

Project Layout..................................................................

Chapter 1:

Press Attitudes Outside the Field of European Integration 22

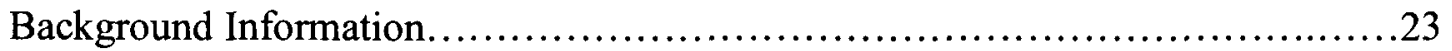

British Press Coverage......................................................25

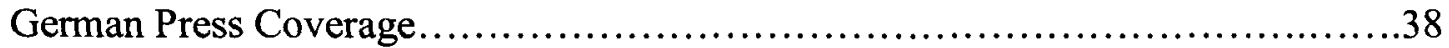

Chapter 2:

Anglo-German Press Attitudes during the Amsterdam and Nice Summits

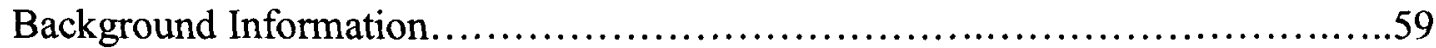

British Press Coverage....................................................67

German Press Coverage................................................. 95

Chapter 3:

Anglo-German Press Attitudes and the

Treaty Establishing a Constitution for Europe

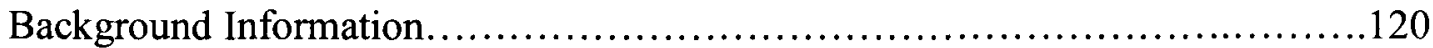

British Press Coverage................................................... 124

German Press Coverage................................................. 154

Conclusion......................................................... 181

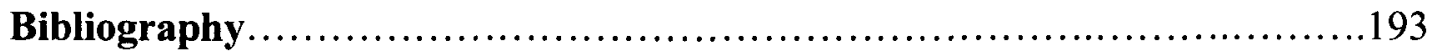




\section{$\underline{\text { List of Figures }}$}

\section{Chapter 1}

Press Attitudes Outside the Field of European Integration

\section{British Press Coverage}

Figure 1.1: Article Coverage, All Newspapers................................25

Figure 1.2a-b: Breakdown by Newspaper.......................................26

Figure 1.3a-b: Average Trend for the Daily Mail................................29

Figure 1.4a-b: Average Trend for the Times.......................................30

Figure 1.5a-b: Average Trend for the Independent ..............................33

Figure 1.6a-b: Average Trend for the Guardian ................................35

Figure 1.7a-b: Average Trend for the Economist...............................37

German Press Coverage

Figure 1.8: Article Coverage, All Newspapers.......................................41

Figure 1.9a-b: Breakdown by Newspaper......................................41

Figure 1.10a-b: Average Trend for Der Spiegel ................................44

Figure 1.11a-b: Average Trend for FOCUS ........................................47

Figure 1.12a-b: Average Trend for the Tageszeitung...............................49

Figure 1.13a-c: Average Trend for the Süddeutsche Zeitung........................51

Figure 1.14a-c: Average Trend for the Berliner Zeitung........................51-52

\section{Chapter 2}

Anglo-German Press Attitudes during the Amsterdam and Nice Summits

\section{British Press Coverage}

Figure 2.1a-b: Article Coverage, All Newspapers..................................67

Figure 2.2a-b: Breakdown by Newspaper (by Frequency)...........................69

Figure 2.3a-b: Breakdown by Newspaper (by Percentage)............................69

Figure 2.4: Average Trend for the Daily Mail.....................................74

Figure 2.5: Germany and Related Themes in the Daily Mail.........................75

Figure 2.6: Treatment of Germany by the Times..................................76

Figure 2.7a-b: Average Trend for the Times (Amsterdam).........................77

Figure 2.8a-b: Average Trend for the Times (Nice)...............................77

Figure 2.9a-b: Germany and Related Themes for the Times.........................78

Figure 2.10: Treatment of Germany by the Independent .........................82

Figure 2.11 a-b: Average Trend for the Independent (Amsterdam)..................83

Figure 2.12: Average Trend for the Independent (Nice)...........................83

Figure 2.13a-b: Germany and Related Themes for the Independent ..................84

Figure 2.14: Treatment of Germany by the Guardian ...............................87

Figure 2.15a-b: Average Trend for the Guardian (Amsterdam).....................87 


\section{List of Figures (cont'd)}

Figure 2.16a-b: Average Trend for the Guardian (Nice)..........................88

Figure 2.17a-b: Germany and Related Themes for the Guardian....................88

Figure 2.18: Treatment of Germany by the Economist..........................92

Figure 2.19a-b: Average Trend for the Economist .............................92

Figure 2.20a-b: Germany and Related Themes for the Economist.................92

\section{German Press Coverage}

Figure 2.21a-b: Article Coverage, All Newspapers................................96

Figure 2.22a-b: Breakdown by Newspaper.......................................98

Figure 2.23: Treatment of Britain by Der Spiegel ...................................101

Figure 2.24a-b: Britain and Related Themes for Der Spiegel......................103

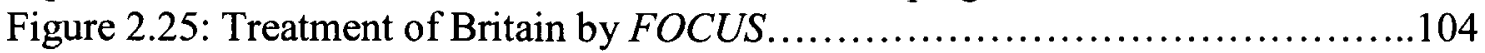

Figure 2.26: Average Trend for FOCUS ...................................... 104

Figure 2.27a-b: Britain and Related Themes for FOCUS ........................ 104

Figure 2.28: Treatment of Britain by the Tageszeitung............................106

Figure 2.29: Average Trend for the Tageszeitung (Amsterdam).......................107

Figure 2.30a-b: Average Trend for the Tageszeitung (Nice)..........................107

Figure 2.31a-b: Britain and Related Themes for the Tageszeitung ...................107

Figure 2.32: Treatment of Britain by the Berliner Zeitung.......................... 110

Figure 2.33a-b: Average Trend for the Berliner Zeitung.............................110

Figure 2.34: Britain and Related Themes for the Berliner Zeitung...................111

Figure 2.35: Treatment of Britain by the Süddeutsche Zeitung......................112

Figure 2.36a-b: Average Trend for the Süddeutsche Zeitung (Amsterdam).............113

Figure 2.37a-b: Average Trend for the Süddeutsche Zeitung (Nice)..................113

Figure 2.38a-b: Britain and Related Themes for the Süddeutsche Zeitung..............114

\section{Chapter 3}

Anglo-German Press Attitudes and the Treaty Establishing a Constitution for Europe

\section{British Press Coverage}

Figure 3.1: Article Coverage, All Newspapers..............................124

Figure 3.2: Breakdown by Newspaper (by Frequency) ............................127

Figure 3.3: Breakdown by Newspaper (by Percentage)........................... 127

Figure 3.4: Treatment of Germany by the Daily Mail .............................130

Figure 3.5a-c: Average Trend for the Daily Mail.................................131

Figure 3.6: Germany and Related Themes for the Daily Mail........................132

Figure 3.7: Treatment of Germany by the Times..................................135

Figure 3.8a-c: Average Trend for the Times....................................136

Figure 3.9: Germany and Related Themes for the Times.............................136

Figure 3.10: Treatment of Germany by the Independent ........................... 140

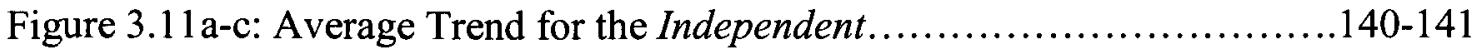




\section{$\underline{\text { List of Figures (cont'd) }}$}

Figure 3.12: Germany and Related Themes for the Independent ....................141

Figure 3.13: Treatment of Germany by the Guardian ..............................144

Figure 3.14a-c: Average Trend for the Guardian ................................145

Figure 3.15: Germany and Related Themes for the Guardian ........................145

Figure 3.16: Treatment of Germany by the Economist ...........................148

Figure 3.17a-c: Average Trend for the Economist..................................149

Figure 3.18: Germany and Related Themes for the Economist.......................149

German Press Coverage

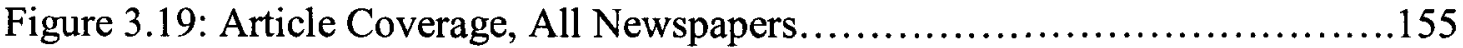

Figure 3.20: Breakdown by Newspaper (by Frequency) ........................157

Figure 3.21: Breakdown by Newspaper (by Percentage)...........................157

Figure 3.22: Treatment of Britain by Der Spiegel ....................................160

Figure 3.23: Treatment of Britain by FOCUS .................................. 160

Figure 3.24a-b: Average Trend for Der Spiegel ...................................161

Figure 3.25: Average Trend for FOCUS ......................................162

Figure 3.26: Britain and Related Themes in Der Spiegel............................162

Figure 3.27: Britain and Related Themes in FOCUS..............................162

Figure 3.28: Treatment of Britain by the Tageszeitung.............................165

Figure 3.29a-c: Average Trend for the Tageszeitung............................166

Figure 3.30: Britain and Related Themes in the Tageszeitung........................167

Figure 3.31: Treatment of Britain by the Berliner Zeitung..........................170

Figure 3.32a-c: Average Trend for the Berliner Zeitung.............................171

Figure 3.33: Britain and Related Themes in the Berliner Zeitung...................172

Figure 3.34: Treatment of Britain by the Süddeutsche Zeitung......................174

Figure 3.35a-c: Average Trend for the Süddeutsche Zeitung.......................175

Figure 3.36: Britain and Related Themes in the Süddeutsche Zeitung................176 


\section{Introduction: The British and the Germans}

In a shop in downtown London, there is a vendor who sells T-shirts. Standing out among slogans such as "Guns don't kill people, people with moustaches kill people," one's eye is drawn to a white T-shirt displaying a map of Europe alongside a giant Adolf Hitler, sporting the brown Nazi party uniform, and giving the salute named after him. Designed to parody a shirt that one might find at a rock concert, it proudly displays the title "Hitler: European Tour 1939-1945," and listed in the style of concert locations and dates are the various European countries that fell to the German war machine in the given year. Such countries are colored on brown on the map of Europe, while standing out in red are Britain and Russia, with the words "Cancelled" appearing alongside the given performance date. Germany proper is coloured in black and sports the Totenkopf, the death's head logo worn by the SS. Surprised as I was to discover that such a shirt was prominently displayed (and indeed existed at all), what drove the point home was that, if one could not find the appropriate sized t-shirt in that particular store, all one had to do was go down the street to another store which stocked the same product.

The presence of such shirts is useful for illustrating the degree to which World War II, and specifically the image of Nazi Germany, is still engrained in the British consciousness. It is widely accepted these days that a mistrust of Germans generally exists among the British public, even though Anglo-German political relations tend to remain friendly. Even those individuals who recognize this, and try to speak more kindly of the Germans, often fall back on stereotypes. For example, in a newspaper article appearing in the Guardian in the year 2001, columnist Julie Burchill describes her negative impressions of the Germans, gained during her childhood, as apparently being 
lessened after her unknowing stay at a hotel that happened to be a German-owned chain. "Having encountered a great many Germans here myself," she declares in a somewhat self-congratulatory manner "I don't think the Germans are so bad at all, and here's why". Unfortunately, the list that follows is full of traditional stereotypes that involve the Germans being humourless, impolite, and speakers of that awful German language, to name but a few. The effect of her concluding sentence, "The Germans, bless them, have changed just enough and no more- and for this they have my affection and respect" ${ }^{2}$ is somewhat lessened by such points as:

I've gotta go there just one more time- that language! Is it eating Spam for breakfast that makes them sound as though they're trying to clear a huge wad of phlegm from their throats, or is it the immortal tongue of Goethe and Nietzche? ${ }^{3}$

Some scholars have attempted to look at this (fairly called) obsession that Britons seem to have with the Germans. In his book, Don't Mention the War: The British and the Germans since 1890 (2006), the British historian John Ramsden argues that since 1945 Britons have consistently been treated to a plethora of media sources that either deal directly with the Second World War or cast Germany as a potential enemy. In the realm of pseudo-historical works, he references the so-called "alternative histories" that were widely produced in Britain and America in the postwar era. These alternative histories deal with "what-if" scenarios, and many try to consider the consequences that might have emerged if World War II had ended differently. In Britain specifically, Ramsden notes that four-fifths of alternative histories written in Britain suppose a victory for Nazi Germany and the successful invasion of the British Isles, which can be linked to the

\footnotetext{
${ }^{1}$ Julie Burchill, "Thinking the wurst," Guardian, Spetember 22, 2001.

${ }^{2}$ Ibid.

${ }^{3}$ Ibid.
} 
tradition of British "invasion literature" which existed in earlier times of Anglo-German tension. ${ }^{4}$ In terms of pure fiction, he chronicles the works of novelists such as Len Deighton, Victor Canning (1960s), Jack Higgins (1970s), Robert Harris (1990s), all of whom were (and are) widely read, and whose works are often based around nightmare scenarios involving Germany. ${ }^{5}$ Finally, on the topic of British television, he notes that free channels tend to carry at least one programme per day about the war, while cable networks average three to four. This leads him to remark that "a dedicated viewer with a VCR could spend his spare time watching the Second World War daily. Some probably do., 6

Britons' uneasiness about the process of European integration has sometimes manifested itself in this spirit. In July of 2002, during the ongoing British debate regarding entry into the single currency zone, from which the United Kingdom had initially secured an opt-out, a comedic advertisement featuring Rik Mayall gained media attention and was criticized by certain groups, including British Jews and supporters of the pro-Euro campaign. In the advertisement Mayall, dressed as Adolf Hitler, proclaimed "Ein Volk, ein Reich, ein Euro!" playing on the Nazi slogan of "Ein Volk, ein Reich, ein Führer." Fears of German military domination before and during the two World Wars had thus found expression in new fears of German economic domination via the European integration project. Even such respected individuals as the historian A. J. P. Taylor had previously felt it necessary to denounce the European Economic Community

\footnotetext{
${ }^{4}$ John Ramsden, Don't Mention the War: The British and the Germans since 1890 (Great Britain: Little, Brown, 2006), 377.

${ }^{5}$ Ramsden, 371.

${ }^{6}$ Ramsden, 382.

7 "Row over spoof Hitler euro advert," BBC News: World Edition, July 3, 2002.
} 
(EEC) in May of 1959 as "working out in practice as a device for bringing all Continental Europe under German control.",

Of course, it is not possible to build a comprehensive picture regarding British attitudes towards Germany and European integration using only these two examples, nor by looking only at the evidence that we have seen so far is it possible to classify British attitudes towards Germany in this field as predominantly negative. However, having examined briefly the obsession that Britons seem to have concerning Germany and its past, it is fair to ask what kind of attitudes exist in the public sphere, whether they are negative or positive, and to what extent themes occur that are in line with those examples given above. It is also necessary for a sense of balance to examine the flip side of the coin, in order to determine what kind of attitudes and themes exist in Germany regarding the British in the European integration project.

\section{Project Justification}

The basic question that this thesis is built upon is "how have the British and German press each portrayed the role of the other country in the European integration project?" However, before additional information is provided and the body of the thesis begins, it is fair to ask why consideration of this question is important. To begin, one purpose of this project is to test the accuracy of a number of pre-existing assumptions about British attitudes towards Germany. One of these is the idea that the British press is generally negatively disposed to Germany, as evidenced in the work of scholars such as

Sabine Lee, who has stated that "the British press has never been favourably disposed

\footnotetext{
${ }^{8}$ Ramsden, 276.
} 
towards the German Republic."9 This project will be able to confirm or refute the existence and degree of this negativity within newspaper reporting, namely as it relates to European integration. Within this topic, it will also be possible to assess the degree to which Nazi imagery pervades the British consciousness, and further shed light on D.C. Watt's assertion made in 1965 (which has more recently been supported by Jonathan Grix and Chantal Lacroix), that "British opinion has remained fixed in the stereotypes established in two world wars."10

Beyond simply seeking to confirm or refute existing assumptions, an examination of the press also serves to illuminate attitudes towards European integration in the public sphere, which may differ from those in the political sphere. In general, the majority of writings that currently exists on Britain and Germany in the European integration project are diplomatic histories, which favour national politics over the press. Take, for example, two relatively recent works, Sabine Lee's Victory in Europe: Britain and Germany since 1945 (2001) and Christian Schweiger's Britain, Germany, and the Future of European Union (2007), which are both are based heavily on government relations between the two countries. Lee occasionally refers to the press in order to clarify a specific point, but this is simply a method of strengthening her argument, and does not serve as a main focus of attention. Schweiger is more concerned with policy considerations and international relations, and thus the press is not mentioned. The general theme of these books is bilateral cooperation between the two countries, and examination of the press will therefore allow us to see if an alternate narrative exists.

\footnotetext{
${ }^{9}$ Sabine Lee, Victory in Europe? Britain and Germany since 1945 (New York: Longman, 2001), 201. ${ }^{10}$ Jonathan Grix and Chantal Lacroix, "Constructing Germany's Image in the British Press: An Empirical Analysis of Stereotypical Reporting on Germany," Journal of Contemporary German Studies 14, no. 3 (2006): 373.
} 
On this note, a further purpose of this thesis is to fill holes in the existing literature. As previously noted, there is a lack of combined works dealing with AngloGerman press relations and European integration, but works written on British press attitudes towards Germany in the postwar era are also in short supply, as are works written on German press views of Britain in general. With regards to the second point, much time has been devoted to studies of the British press and Germany prior to 1945, and these tend focus on fascism. ${ }^{11}$ Fewer works exist that look at the postwar era, although it is true that some works related to my topic have emerged more recently. However, most lack the specific focus of this thesis. Worthy of mention is John Ramsden's previously-mentioned work Don't Mention the War: The British and the Germans since 1890 (2006), which focuses on relations between the two countries but not press attitudes specifically, and Peter Anderson and Anthony Weymouth's Insulting the Public? The British Press and the European Union (1999), which looks broadly at the portrayal of the European integration project in the British press.

Most similar to this project, and to which I am indebted for a number of ideas is Jonathan Grix and Chantal Lacroix's "Constructing Germany's Image in the British Press: An Empirical Analysis of Stereotypical Reporting on Germany" in the Journal of Contemporary European Studies (December 2006). This work examines British newspaper coverage of Germany over the course of the year 2001 with the intent of determining whether the commonly held belief that British newspaper coverage of Germany is negative, and stereotypical, holds true or not. The main differences between Grix's work and this thesis are in focus and scope: while Grix discussed Germany's EU

\footnotetext{
${ }^{11}$ Patrick Major, "Britain and Germany: A Love-Hate Relationship?" German History 26, no. 4 (2008): 465.
} 
image, it is not a major focus, and further, where Grix only examines one year of newspaper coverage, this project looks at events occurring over the course of several. Additionally, as is the case with all of the sources that have been mentioned thus far, Grix's work contains no examination of German press attitudes regarding Britain. This brings us to the final gap which this project hopes to fill, namely that little has been written on the attitudes of the German press towards Britain in any time period.

Returning to the overall purpose and relevance of this project, the final and perhaps most important point is that, by examining press attitudes and themes over time, this thesis will allow us to witness the construction and maintenance of national images in Britain and Germany as they relate to European integration. As Grix and Lacroix have noted, the image of one nation within another is constructed in large part through the media, and especially print media, which is a principle method by which individuals learn about their environment. ${ }^{12}$ Based on a constructivist approach, recurring themes (or stereotypes) in print media can become imbedded in a nation's psyche, and therefore affect how a nation's citizens view reality. ${ }^{13}$ Ultimately, this means that this thesis goes beyond simply being an examination of press attitudes to becoming an examination of the shaping of the national attitudes of Britain and Germany towards the other country in the European integration process. Of course, for this last point to apply, we must subscribe to the view that individuals can be affected by the information that they read, which is a position not accepted by all scholars. ${ }^{14}$

\footnotetext{
${ }^{12}$ Grix, 374 .

${ }^{13}$ Grix, 376.

${ }^{14}$ Grix, 375.
} 
Background Information: The British and German Press

Newspapers in Britain can boast of a long history, having been an important facet of British life since the early 1700 s, when numerous titles emerged following the relaxing of publication controls which followed the Civil War of the previous century. ${ }^{15}$ Even today, with questions having been raised regarding the continuing relevance of print media in an increasingly digital world, it has been found that newspapers continue to constitute one of the key channels through which a majority of British citizens choose to educate themselves and form opinions on a given topic. In fact, Sanna Inthorn has noted that, along with audiovisual material, printed media is the most common source that the British use for information on the EU. ${ }^{16}$ Newspaper readership remains relatively high, and according to a poll in the year 2001 some $87 \%$ of males and $82 \%$ of females had read one within the previous week. ${ }^{17}$

Compared to Britain, Germany has a much younger national press and a much more fragmented press sector in general. This first point reflects her late unification and subsequent political history, both of which hindered the development of the free press as it arose in Britain. All of the German newspapers used in this project were founded after the elimination of Nazi press controls following Second World War, with some being established quite quickly, and others like FOCUS and the Tageszeitung emerging only decades later. The fragmented nature of the German press speaks to Germany's history of, and tendency towards, regionalization, with Germany boasting approximately 1,500 newspapers overall. ${ }^{18}$ Even those newspapers with national circulation tend to have their

\footnotetext{
${ }^{15}$ Mick Temple, The British Press (New York: Open University Press, 2008), 1.

${ }^{16}$ Sanna Inthorn, German Media and National Identity (New York: Cambria Press, 2007), 41.

${ }^{17}$ Grix, 374, 377.

${ }^{18}$ Inthorn, 27.
} 
editorial offices in regional cities rather than the national capital. ${ }^{19}$ Newspaper readership remains relatively high in Germany, with the country ranking fifth in the world for overall newspaper sales in 2005 , and 2006 figures indicating that 305 newspapers are sold for every 1,000 inhabitants. $^{20}$

Although the specifics of each newspaper used in this thesis are discussed later, it is important to note that, generally speaking, Britain and Germany hold differing viewpoints regarding the European integration project, and this difference tends to be reflected in the press of each country. According to a recent article run by the Economist,

In much of Europe people look to the EU as a higher authority able to rescue them from dysfunctional local rulers, notes one ambassador. Britain, he says, is one of the few countries whose voters assume domestic administration is superior to the EU's...The British debate on Europe is also affected by a raucous popular press that lazily presents the EU as a nefarious plot to do the country down. National newspapers on the continent are overwhelmingly pro-establishment and therefore pro-EU. British newspapers may reflect a more Eurosceptic public opinion. ${ }^{21}$

These assertions are borne out by evidence from scholarship on the topic. Anderson and Weymouth have noted that a majority of British newspapers are weighted towards the right-of-centre, with 11 of the 19 major daily newspapers being unequivocally rightwing, and that "due to the concentration of ownership and the dominance of the right in this media sector, Eurosceptic voices are in the majority." ${ }^{22}$ By contrast, Sanna Inthorn notes that "West German broadsheets have been favourable towards European integration for decades, presenting it as a platform through which German sovereignty can be

\footnotetext{
19 “The Press in Germany," BBC News Europe, http://news.bbc.co.uk/2/hi/europe/3414139.stm (accessed August 1, 2010).

${ }^{20}$ Ibid.

${ }^{21}$ Charlemagne, "Perfidious Albion again," Economist, week of May22-28, 2010.

${ }^{22}$ Peter Anderon and Tony Weymouth, Insulting the Public? The British Press and the European Union (New York: Addison Wesley Longman, 1999), 60-61.
} 
retained. ${ }^{, 23}$ It therefore becomes an objective of this project to determine the degree to which general attitudes towards European integration in these two countries affect the press coverage of the other when discussing the topic.

\section{Goal and Scope of this Project}

To answer the basic question posed by this thesis (How have the British and German press each portrayed the role of the other country in the European integration project?), I use data collected from newspaper sources surrounding key events (focal points) in the history of European integration. Guiding my research are a number of hypotheses and goals. In terms of the former, some are based on general assumptions that exist within the current scholarship, and some are simply findings that can reasonably be expected to be true:

- Based on scholarly assumptions and findings so far, I expect that overall press coverage (particularly in the British press) will be negative;

- Given that much has been written on Britain's obsession with Germany, I expect the British press to show more concern with Germany than the German press shows with Britain;

- I expect that a newspaper's stance on the EU will affect its attitudes regarding the opposing country; and finally

- I expect attitudes within an EU context to differ markedly from those in non-EU coverage.

\footnotetext{
${ }^{23}$ Inthorn, 40.
} 
The goals that have been set are in line with the multiple purposes of this project, as mentioned in the "Project Justification" section above:

- Through my 5-point coding methodology (discussed later), I seek to measure the amount and degree of negativity and positivity that exists in each press group;

- Within an EU context, I intend to look for common themes and stereotypes, and examine the ways in which these are portrayed over time;

- I seek to examine and comment on the particular nuances of each newspaper under examination; and

- I intend in the conclusion to comment on the relevance of this project for national image construction and identity.

This work is predominantly descriptive, in that my main focus is to answer my research question and address my hypotheses through the gathering and interpretation of data. However, in certain places I also insert analysis and explanation in order to provide context and greater depth; I attempt to build a "thick description," to use Clifford Geertz's term. Under examination are key events in European integration that affected both Britain and Germany, and the responses and attitudes to these events that manifested in the opposing countries' press. For the sake of clarity, "Germany" in this project defines the Federal Republic of Germany from 1949 until 1989, and the entirety of the reunited country thereafter.

In order to limit the size of the project, and due to the availability of primary sources, only events occurring between 1989 and 2005 have been selected as focal points. By this time, both Germany and Britain had been members of the European Community 
(EC) for a significant amount of time, and both were taking interest in the actions of the other country in relation to this. The events under examination were selected based on the likelihood that the press in both Britain and Germany would have discussed the position of the other. The focal points covered include:

i) The Amsterdam summit, 1997

ii) The Nice summit and Irish rejection, 2000/2001

iii) The European Constitution and French rejection, 2004/2005

Additionally, two test cases are examined that do not concern the European integration project. These are intended to act as reference points against which the findings in the above cases may be compared. These test cases are:

i) British press coverage of German reunification, 1990

ii) German press coverage of the British Foot-and-Mouth Disease outbreak, 2001

\section{Sources \& Methodology}

The primary source data for this project comes from the coverage of these events by five national newspapers from both Britain and Germany. These sources have been selected according to online availability, and each is consistently available in each country for each time period under examination. ${ }^{24}$ The British newspapers (including, where relevant, their Sunday publications ${ }^{25}$ ) that this project is centered around consist of the more respectable centre-left Guardian, the more conservative Times, and the

\footnotetext{
${ }^{24}$ With one exception: Berliner Zeitung data is not available for coverage of the Treaty of Amsterdam in Chapter 2.

${ }^{25}$ Data from the Times and Daily Mail include information gathered from the Sunday Times and Mail on Sunday.
} 
Independent. To add breadth, the weekly business and international affairs publication the Economist and the tabloid Daily Mail have been used as well. The German national newspapers used include the centrist Süddeutsche Zeitung, the centre-left Berliner Zeitung, and the independent Tageszeitung, with the highly popular Der Spiegel and more conservative FOCUS included as weekly international affairs publications. It is believed that the sources which have been selected have both significant readerships and different political stances, so that they might be taken together to form a sufficient cross-section of the British and German press.

The newspaper articles that were used for this project were all retrieved electronically using the internet search database Factiva, which had the advantage of being both fast and allowed for standardized searches across all sources. Relevant articles for a given focal point were found through the use of a multiple keyword search. For the British sections, the selected newspapers were always searched for articles containing the key root word "German*" along with additional situation-specific keywords (e.g. "Amsterdam treaty") within a specified timeframe, which was usually a period of two to three months surrounding the event in question. This had the effect of generating articles that discussed both the event in question and Germany or the Germans. To search German newspapers, a more complex search containing situation-specific keywords along with the numerous nouns and adjectives that might refer to Britain and the British was used. All generated articles were then visually scanned, with irrelevant ones being discarded, and relevant ones being assigned a numerical value according to preestablished coding criteria for positivity and negativity (explained below). 
It should be noted that all articles that contained reference to either the Germans or the British and a given focal point were considered to be relevant to this project, regardless whether it was the main focus of the article or not. Many articles consisted of the latter type, and in these cases the coding of an article was consistent with the coding of a limited number of statements. In cases where an article was lengthy and contained numerous or even opposing sentiments, it was coded according to the feeling that it produced overall.

Relevant articles were coded by being assigned one of five possible numerical values on the scale from -2 and 2 (decimal values were not used), with positive numbers indicating the degree of positivity, and similarly with negative numbers indicating the degree of negativity. ${ }^{26}$ This scale was selected in an attempt to offer a more nuanced understanding of the attitudes presented in a given newspaper than a simpler scale might offer. A value of 2 represents the extremes of the scale, and these were assigned when the author of a given article went beyond the simple reporting of a given issue in order to either emphasize a factor (such as economic performance) or provide an editorial opinion that was unambiguously positive or negative.

\section{Example of a Positive Statement}

Britain should welcome German unity without reserve. We have no reason to fear a Germany which is democratic and rich. The new giant will be the locomotive of Europe, propelling our continent towards its second economic miracle since the war. $^{27}$

\footnotetext{
${ }^{26}$ It should be noted that this 5-point coding scale is an expanded version of the more traditional 3-point coding scale (positive, negative, neutral) used by political scientists. To the best of my knowledge, the 5point system is my own creation.

27 "Kohl and the Iron Lady," Daily Mail, March 30, 1990.
} 
Example of a Negative Statement

I find it hard to believe in the idea of a united Germany as a dutiful partner in Nato. It is an idea that is not in line with the Zeitgeist of the last decade of the 20 th century, which is increasingly nationalist. ${ }^{28}$

A value of 1 was assigned both to articles that either reported on positive or negative events without indicating a strong preference, or to articles that contained undercurrents of positivity or negativity, but which were not directly stated.

Example of a Neutral-Positive Statement

The Germany of 1990 ought to be an amiably self-confident place. It is about to become one country again. ${ }^{29}$

Example of a Neutral-Negative Statement

German unification has put on another burst of speed in recent days. But the bow waves from that swiftly-moving vessel continue to disturb the sheltered harbours of foreign ministries throughout Europe. ${ }^{30}$

Finally, a value of zero was assigned to articles that were neutral in nature. Neutral articles were generally those that passively reported on events that were neither positive nor negative in nature, although there were rare cases where an article was coded as neutral due to a balance of positive and negative statements.

\section{Example of a Neutral Statement}

The future of Germany was also an issue in the talks between Mr Gorbachev and Mr Baker. ${ }^{31}$

\footnotetext{
28 "Russia's German Dilemma," Times, February 9, 1990.

29 "Unification with W Germany should not mean an end to the American Connection," Economist, February 10, 1990.

30 "German Unification: Making Waves," Independent, February 8, 1990.

31 "Gorbachev proposes new troop deal," Independent, February 10, 1990.
} 
After all articles were coded, the data generated in this manner was then interpreted separately for each newspaper under examination, in order to reveal particular trends. Once this step was completed, newspaper coverage within a given country was then compared in order to ascertain more general trends or lack thereof.

It is hoped that the use of this five-point methodology will allow for a greater understanding of the examined press sources than might be possible if only a three-point model (positive, negative, neutral) were used. The five-point model allows, for example, the reader to note the difference between newspapers that takes a predominantly negative attitude towards the opposing country by means of a strong editorial line, as opposed to those which takes a negative attitude by merely reporting on the negative happenings in that country. In using any sort of coding methodology, the author is aware that there is still room for ambiguity, although it is hoped that any issues will be largely resolved in the discussion of the individual press coverage itself.

\section{British Newspapers}

\section{Times}

The Times is a national British daily that has existed in various forms since its founding as the broadsheet Daily Universal Register in 1785. The Times and its sister newspaper, the Sunday Times, are Murdoch publications and fall under the category of the so-called Tory press, and are therefore examples of the previously-mentioned newspapers that tend to be weighted towards the right-of-centre in their reporting. Circulation numbers for the Times from 2001-2006 indicate a daily readership of approximately $600,000 .{ }^{32}$ Regarding European integration, the newspaper has been found to take a broadly Eurosceptic line,

\footnotetext{
${ }^{32}$ Grix and Lacroix, 377.
} 
rejecting European Monetary Union and containing recurring themes of economic and social anxiety when the issue is discussed. ${ }^{33}$

\section{Guardian}

The Guardian (formerly Manchester Guardian, founded in 1821) is the most significant British national daily that attracts a left-of-centre readership. Daily circulation is somewhat lower than that of the Times, although higher than that of the Independent, with approximately 375,000 in 2002 , although that number had dropped to around 360,000 in $2006 .{ }^{34}$ The Guardian can be classified as Europhile in its stance regarding European integration, ${ }^{35}$ and although it is known to comment on the problems that integration raises, Anderson and Weymouth were unable to find evidence of a hard Eurosceptic presence during the time period they examined. ${ }^{36}$ As a further point that may be relevant to this project, Grix has found in his study that the Guardian tends to be more positively disposed towards Germany and the Germans than does the Times. ${ }^{37}$

\section{Independent}

The Independent is a highly successful independent daily newspaper that was launched in 1986 as an alternative to Thatcherite conservatism and the Murdoch press. ${ }^{38}$ Generally considered a left-of-centre publication, the Independent has no true political affiliation, although the majority of its approximately 240,000 readers are Liberal Democrats. ${ }^{39}$ On

\footnotetext{
${ }^{33}$ Anderson and Weymouth, 65 .

${ }^{34}$ Grix and Lacroix, 377.

${ }^{35}$ Peter Anderson, "A Flag of Convenience? Discourse and Motivations of the London-based Eurosceptic Press," Journal of European Studies 20 (2004): 151.

${ }^{36}$ Anderson and Weymouth, 98.

${ }^{37}$ Grix and Lacroix, 385.

${ }^{38}$ Temple, 80.

39 Temple, 81, 191.
} 
European integration, Anderson and Weymouth have found that the Independent is predominantly pro-European with Eurosceptic undertones lingering in certain of its aspects, including the single currency. ${ }^{40}$

\section{Daily Mail}

The Daily Mail and its sister publication, the Mail on Sunday, are widely-read black-top tabloids, boasting a circulation of approximately 2.3 million. ${ }^{41}$ Generally professional and well-written for a tabloid, the Daily Mail tends to take a conservative line, and it has been noted that the Mail's readership "forms the largest concentration of 'swing voters' who can be reached through a single newspaper. ${ }^{, 42}$ Like the Times, this newspaper takes a broadly Eurosceptic view of European integration. ${ }^{43}$

\section{Economist}

The Economist is a weekly international affairs publication based in London and boasts a readership of approximately 1.6 million. It is generally considered to have conservative leanings, although this is not always evident due to its many and varied contributors. Its articles often have a strong editorial line, and in general the Economist favours economic liberalization by advocating globalization and free trade. The publication accepts British participation in the European integration project, although its vision of Europe is based more on economic cooperation than political integration. Since the mid 1990s, the

\footnotetext{
${ }^{40}$ Anderson and Weymouth, 94-95.

${ }^{41}$ Temple, 81 .

${ }^{42}$ Temple, 91.

${ }^{43}$ Anderson, 151.
} 
Economist has striven for a decentralized model of Europe based on this principle, as well as that of democratic accountability. ${ }^{44}$

$\underline{\text { German Newspapers }}^{45}$

Süddeutsche Zeitung

Founded in late 1945, the Süddeutsche Zeitung is one of the best-selling German national broadsheet newspapers, boasting a circulation of approximately 450,000 nationwide, although it takes much of its readership from Bavaria, and particularly from Munich, the place of its publication. The newspaper is considered left-of-centre and generally favours a liberal social outlook and supports democratic and social reforms. ${ }^{46}$

\section{Berliner Zeitung}

The Berliner Zeitung is a centre-left daily published in Berlin and sports a national readership of 170,000. Founded in the same year as the Süddeutsche Zeitung, this newspaper is the only East German publication to become nationally prominent since German reunification. Said to contain contributors from both East and West Germany, the newspaper styles itself as a young, modern and dynamic newspaper for the entire country. ${ }^{47}$

\footnotetext{
${ }^{44}$ Juan Diez Medrano, Framing Europe: Attitudes to European Integration in Germany, Spain, and the United Kingdom (Oxford: Princeton University Press, 2003), 129, 139.

${ }^{45}$ Unless otherwise noted, all German newspapers are taken to be pro-European.

${ }^{46}$ Inthorn, 28.

47 "The Press in Germany," BBC News Europe, http://news.bbc.co.uk/2/hi/europe/3414139.stm (accessed August 1, 2010).
} 


\section{Tageszeitung}

Like the British Independent, the Tageszeitung is a national newspaper founded in 1979 as an alternative to the mainstream press. It is a cooperatively owned daily based in Berlin, and it is known for its frequent support of left-wing issues in general and the German Greens in particular. Daily circulation as of 2006 was approximately $60,000{ }^{48}$

\section{Der Spiegel}

Der Spiegel is a highly popular weekly German news magazine that boasts a circulation of 970,000 in Germany. Well known for its uncompromising and investigative journalism, Der Spiegel has had a history of championing democracy and uncovering political scandals since its establishment in 1947. Although it is generally considered a left-wing publication, it has been noted that the magazine tends to take a critical view of any topic which it happens to discuss, and until his death in 2002, its founder Rudolf Augustein occasionally allowed space for more conservative articles. ${ }^{49}$

\section{FOCUS}

Considered an alternative to Der Spiegel, FOCUS is a weekly magazine with a circulation of approximately 714,000 . However, where Der Spiegel is renowned for its investigative journalism and political commentary, FOCUS is more lifestyle-oriented, containing shorter articles and greater use of graphics. Although it does provide limited social commentary, the magazine has been accused of offering its readers insufficient

\footnotetext{
48 “The Press in Germany," BBC News Europe, http://news.bbc.co.uk/2/hi/europe/3414139.stm (accessed August 1, 2010).

${ }^{49}$ Inthorn, 30.
} 
information to allow for an independent opinion. Like the British Economist, FOCUS is considered conservative, and tends to favour economic liberalism. ${ }^{50}$

\section{Project Layout}

In terms of structure, this thesis is divided into three main chapters and a conclusion. Each of the main chapters is further divided into three sections. The first is intended to provide the reader with some brief background information in order to place the event in its historical context, while the second and third section respectively examine the British and German press coverage of the event. The first chapter examines the test cases that are external to the European integration project, namely British coverage of German unification and German coverage of the Foot-and-Mouth Disease outbreak in Britain. This chapter serves as a reference point against which the findings of the later chapters can be compared, and is intended to increase the relevance of this project by ensuring that the findings from the chapters on European integration do not exist in a vacuum. The second chapter examines two focal points together, specifically the Amsterdam and Nice summits. These have been combined because both can be considered important but not earth-shattering events in the history of European integration, and further because the amount of press coverage for each summit was not sufficient to warrant that each be given its own chapter. Conversely, Chapter 3 examines the press coverage of the European constitutional project, a major event that was controversial enough to easily generate the most newspaper coverage of any focal point examined in this thesis. Finally, the conclusion summarizes the findings in this thesis and comments on their implications.

\footnotetext{
${ }^{50}$ Inthorn, 30-31.
} 


\section{Chapter 1: Press Attitudes Outside the Field of European Integration}

Before we approach the heart of the subject matter under examination in this thesis, that is, the press attitudes in both Britain and Germany regarding the other country in the European integration project, it is necessary to examine press attitudes in areas that are not directly related to this process. Doing so allows us to establish a baseline against which attitudes surrounding European integration can be compared, thus increasing the overall relevance and impact of this project. Accordingly, this chapter is divided into two parts, each of which examines the national press coverage of a non-integration event that took place in the other country. The first section looks at British coverage of the German unification process as it unfolded in the months of February and March 1990, and the second section looks at German press coverage of the Foot and Mouth Disease epidemic in Britain, ${ }^{51}$ from its outbreak in February 2001 until it ceased to be headline news in late April of the same year. These events were chosen based on the idea that they were important enough to draw significant press coverage in the opposite country when they occurred. Furthermore, they were also selected based on the idea that the events themselves were powerful enough that their coverage in the press would draw out the attitudes or stereotypes, whether positive or negative, which existed towards the opposing country that might otherwise have been masked by a certain degree of professionalism during the coverage of more mundane subjects. Admittedly, the impact of German unification cannot be truly matched in its scope by a similar event during British history that falls into the time period under examination. Nonetheless, it is believed that these two events will be adequate in achieving the proposed purpose.

\footnotetext{
${ }^{51}$ Hereafter referred to as FMD; called Maul-und-Klauenseuche (MKS) in German.
} 


\section{Background in Brief}

The years 1989-91 were arguably the most groundbreaking in recent history, as they bore witness to the unexpected and rapid demise of communism, ultimately resulting in the end of the Cold War, the existence of which had dominated international politics for the previous fifty years. Following the opening of the Hungarian border to Austria in late summer of 1989 , citizens of East Germany were able to freely travel to the West, and the subsequent chain of events culminating in the fall of the Berlin Wall on 9 November 1989 once again brought the "German Question" to the fore in Europe. Ultimately the two Germanies would be reunited in short order, although the process by which this was achieved was far from painless. The newspaper articles that are examined in this section come from a time when the decline of Soviet power and the seemingly inevitable pace of reunification raised questions both inside and outside Germany about what form the reunited country would take, and what role a unified Germany would play both in Europe and the wider world. Under specific focus in this chapter are the reactions of the British press to these events in the months of February and March 1990, during which the Ottawa Conference on German reunification and the first democratic elections in the German Democratic Republic respectively took place. Also occurring in March was the so-called Chequers-Ridley affair in Britain, which followed directly from the Ottawa Conference.

The Ottawa Conference followed a decisive meeting between Chancellor Helmut Kohl of West Germany and Mikhail Gorbachev, the General Secretary of the Communist Party of the Soviet Union, in Moscow on February 10. During this meeting, Gorbachev had indicated that the Soviet Union would not stand in the way of German reunification, 
greatly increasing the likelihood that it could be carried out in practice. ${ }^{52}$ Within a few days of this concession, the Allies had agreed to take part in a conference in Ottawa, Canada, where negotiations on this process would take place. ${ }^{53}$ Present at this conference were representatives from the two German states, plus the four occupation powers, Britain, France, the Soviet Union, and the United States, thus beginning the "two plus four talks." It was at this conference that all participants first formally accepted German reunification, with the external aspects being dealt with and discussed by the four occupation powers, and the internal aspects being left to the two Germanies. ${ }^{54}$

Bilateral political relations between Britain and Germany were relatively tense at this time. British Prime Minister Margaret Thatcher openly expressed her concerns regarding German reunification on more than one occasion, and the frequent criticisms emerging from both the British and French delegates during the conference resulted in intense frustration on the part of the Germans ${ }^{55}$ For her part, the Prime Minister attempted to justify her stance on reunification by calling on British and American experts to a meeting at Chequers in order to discuss the pitfalls of the process and how Britain should respond. ${ }^{56}$ The leaked minutes from this meeting contained frequent use of negative German stereotypes, and this, combined with anti-German comments made by the British Secretary for Trade and Industry Nicholas Ridley, became known as the Chequers-Ridley Affair, which further cooled political relations.

\footnotetext{
${ }^{52}$ Pekka Kalevi Hamalainen, Uniting Germany: Actions and Reactions (Boulder: Westview Press, 1994), 115-116.

${ }^{53}$ Sabine Lee, Victory in Europe? Britain and Germany since 1945 (New York: Longman, 2001), 203.

${ }^{54}$ Hamalainen, 117-118.

${ }^{55}$ Hamalainen, 119, and Lee, 203.

${ }^{56}$ Lee, 204.
} 
This cooling of bilateral relations is not expected to significantly impact the attitudes expressed by the British press towards Germany at the time period in question, thus limiting the risk of a skewed test case. As Grix and Lacroix have noted, the political relations between the two countries tend to be quite unconnected to the attitudes towards Germany expressed in the British press. ${ }^{57}$ In any case, the attitudes expressed during this period may now be examined, so as to provide general data against which the findings in other chapters may be compared.

\section{Eye on Germany: The British Press and German Reunification, February-March 1990}

Newspaper Coverage and Interpretation Overall

The data upon which this section is based comes from a total of 276 articles from the five newspapers mentioned above. Figure 1.1 shows how this information compares overall, while Figures $1.2 \mathrm{a}$, and $1.2 \mathrm{~b}$ display the breakdown per paper.

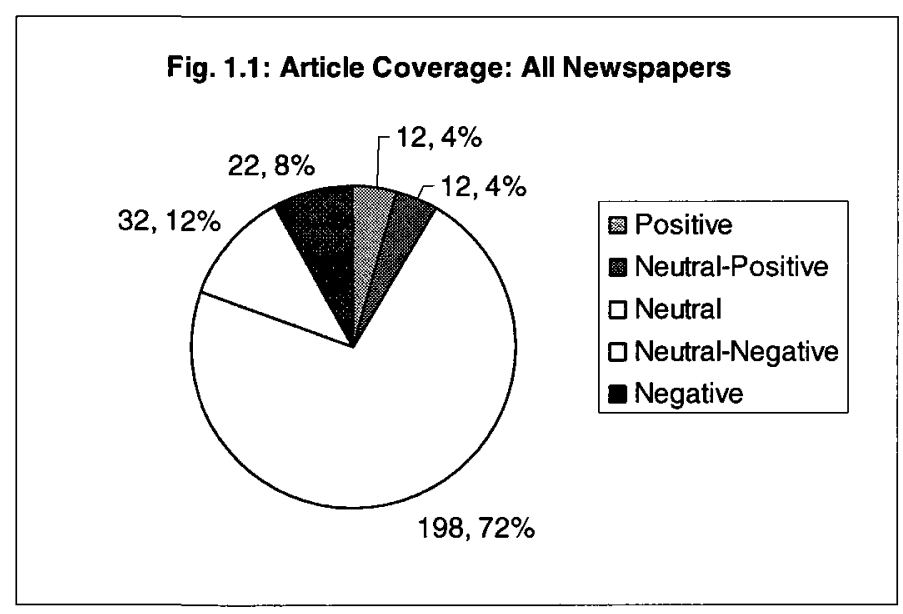

\footnotetext{
${ }^{57}$ Jonathan Grix and Chantal Lacroix, "Constructing Germany's Image in the British Press: An Empirical Analysis of Stereotypical Reporting on Germany," Journal of Contemporary German Studies 14, no. 3 (2006): 374.
} 

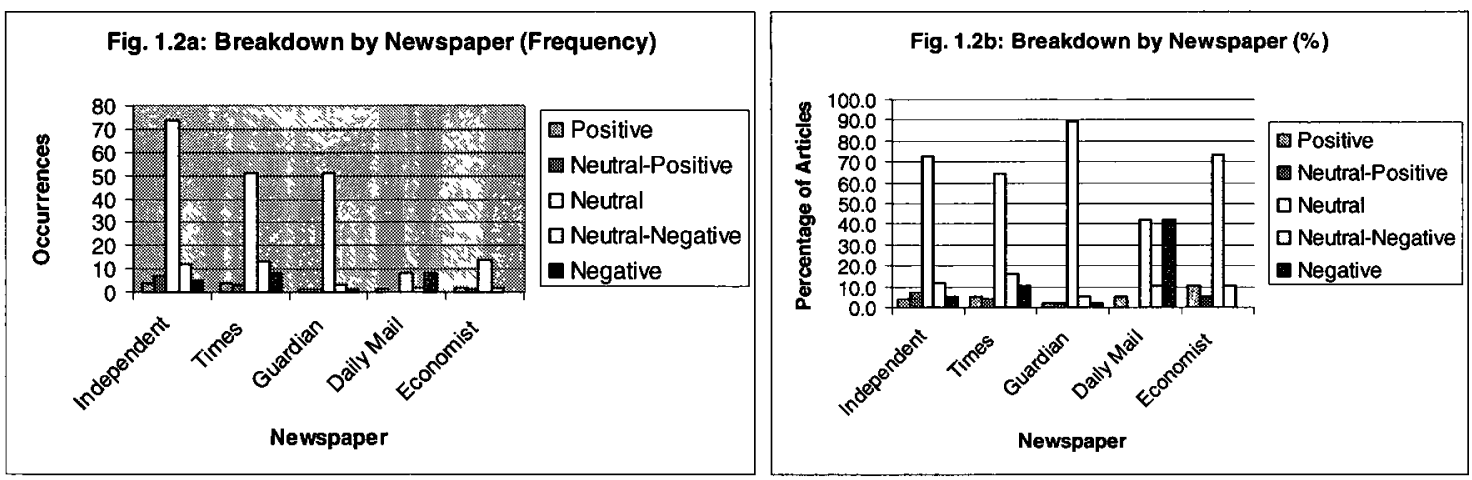

Looking at these graphs, four general conclusions can be drawn about British press attitudes towards Germany at this time.

\section{1) The majority of press coverage was neutral.}

Comparing these figures, we can see that the majority of articles concerning Germany that were written at the time of German unification were neutral in nature, amounting to a total of $72 \%$ overall. Figure $1.2 \mathrm{~b}$ shows that the five newspapers were quite similar in their proportional coverage, with the high and low end of this scale respectively made up by the Guardian (89.5\%) and the Daily Mail (42.1\%), while the remaining three newspapers stuck within $10 \%$ of each other (Independent $72.5 \%$, Times $64.6 \%$, Economist 73.7\%). Despite the frequent tendency of newspapers to take an editorial stand on a given topic, this high number of neutral articles is to be expected as a result of the passive relay of information.

2) When neutral articles are discounted, press coverage was generally negative.

Despite the high percentage of neutral articles, overall there were twice as many negative articles as positive, and three times as many neutral-negative articles as neutral-positive (see Fig. 1.1). Combining these two values, there were more than twice as many negative 
articles as positive. Looking to Figure 1.2b, we can see that although exact proportions differ, with the exception of the Economist, all newspapers contain more negative articles than positive, and more neutral-negative articles than neutral-positive. We can therefore say that, discounting neutral articles, the British press was generally negatively disposed towards Germany and the Germans at this time. This is in line with my hypothesis in the introduction, which assumes, based on the assertions of various scholars, that antiGermanism in the British press is a general rule.

\section{3) The negativity was not necessarily blatant.}

With the exception of the Daily Mail, all newspapers contained more neutral-negative articles than negative, meaning that negativity was more likely to be subdued (appearing as reports on negative happenings, or as an undercurrent) than blatant (editorial or specifically emphasizing a negative factor). The use of my 5-point coding methodology has brought out this distinction, and if this trend holds in subsequent chapters, it will prove to be an important qualification to pre-existing scholarly assumptions about negativity.

4) We are able to determine the relative negativity of each newspaper.

Among the press sources examined in this focal point, the Daily Mail was proportionally the most negative, with as many negative articles as neutral, and the Economist was the most positive with no negative articles at all. The overall order of descending negativity is therefore the Daily Mail, Times, Independent, Guardian, and Economist. Although the sources and focus of this thesis differ somewhat from Grix's work, these results are to some extent supported by his findings. This is particularly true with reference to the 
relative negativity levels between the Times and Guardian (the Daily Mail, Independent, and Economist did not appear in his study). Grix found the Guardian to score proportionally low in negative stereotypes of Germany, and high in the most positive, thus possibly accounting for its relatively low negativity here. He further found the Times to be more negative. ${ }^{58}$

These general findings can thus form a basis against which articles taken from events concerning European integration can be compared, although it will also be helpful to take a more detailed look at individual press trends, in order to determine if common themes and concerns about Germany arise. This may allow us to confirm or refute some existing assumptions about British press treatment of Germany, and further give us some idea about how the image of Germany in the British press is generally constructed.

\section{Individual Trends and Themes}

There are some interesting trends that should be mentioned among individual newspapers. The Daily Mail, which contained relatively few articles (19) in the twomonth period under examination, was nonetheless the most openly negative towards Germany, containing as many negative articles as neutral (8). As can be seen from Figures $1.3 \mathrm{a}$ and $1.3 \mathrm{~b}$, the average trend of articles remained unambiguously negative for the two months being examined, with none of the positive fluctuations evident in most of the other newspapers under examination.

\footnotetext{
${ }^{58}$ Grix, 385 .
} 

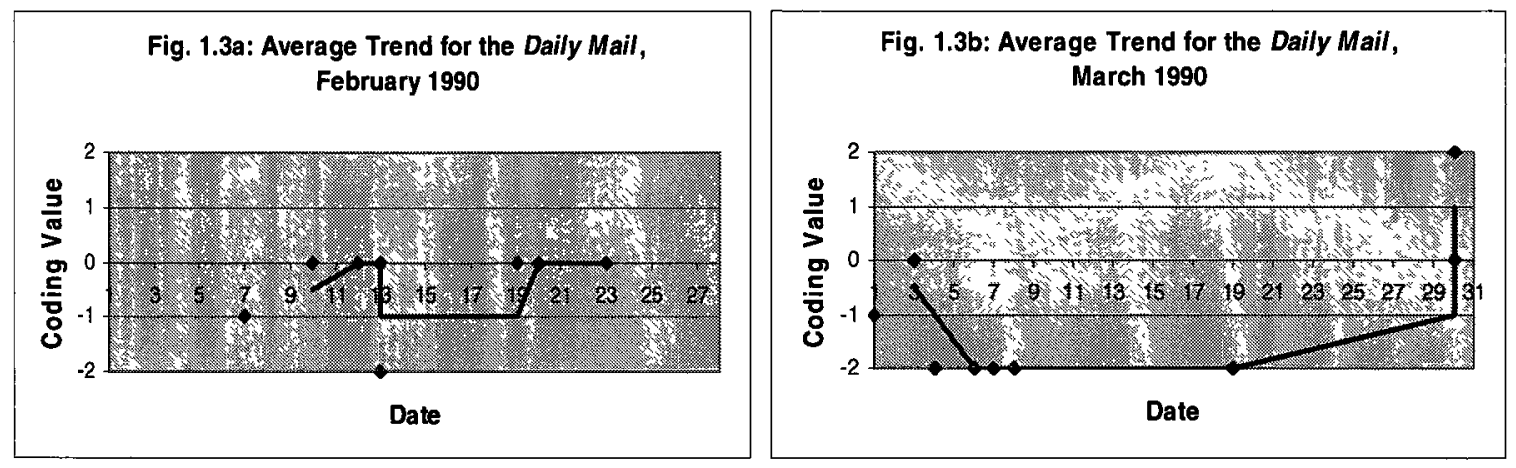

The focus of articles coded as neutral and neutral negative tended to focus on the security of Europe in light of German unification, and often contained comments made by Margaret Thatcher on this topic. Apprehension was evident in most of these articles, which sometimes made reference to the Second World War:

The rush to one Germany should not leave East or West Europe feeling `any less secure,' went on Mrs Thatcher. Negotiations on that unity must centre on Germany's present rather than pre-war borders. ${ }^{59}$

Generally however, the Daily Mail did not rely on passive reporting in order to convey its negative attitudes towards Germany, as this was accomplished by articles containing a strong editorial line. The most common negative articles presented a negative view of growing German power and often made allusions to the Nazi period, confirming the continued existence of this stereotype. One of the most blatant stated:

As events unfold in Europe and Germany becomes ever more powerful and ever more flag wavingly nationalistic, don't you sometimes feel you are watching the re-run of a Thirties black and white movie ? ${ }^{60}$

Further articles reported negatively on the actions of Kohl, and further questioned the trustworthiness of the Germans. In light of articles such as these, the appearance of a positive article at the end of the period under examination that stated "We have no reason

\footnotetext{
59 "Maggie: Beware and Unseen Enemy; Danger of Peace that Follows Cold War," Daily Mail, February $19,1990$.

60 "The John Junor Coumn," Mail on Sunday, March 4, 1990.
} 
to fear a Germany which is democratic and rich. The new giant will be the locomotive of Europe, propelling our continent towards its second economic miracle since the war," seemed entirely out of place. Although this article may be confusing, it perhaps indicates a willingness to look positively at the role of Germany in an interconnected Europe, and it will be up to the rest of this study to determine if this is true. In any case, the overall negativity of the Daily Mail towards Germany, at least at the time of unification, is obvious.

Of all the newspapers under examination in this period, the most interesting observations can perhaps be made with regard to the Times. As in most of the newspapers examined, coverage of German unification in the Times consisted of a large number of neutral articles (51), which most often relayed the news in a passive manner, reporting on the actual process of German unification, or relaying speeches by various politicians. A seemingly primary concern of the Times that emerged in these articles was the security of Europe, specifically with regards to the possibility of German neutrality, or the country's relationship with NATO. Consideration of Germany's place in the European Community (later EU) formed a secondary theme that was often discussed.
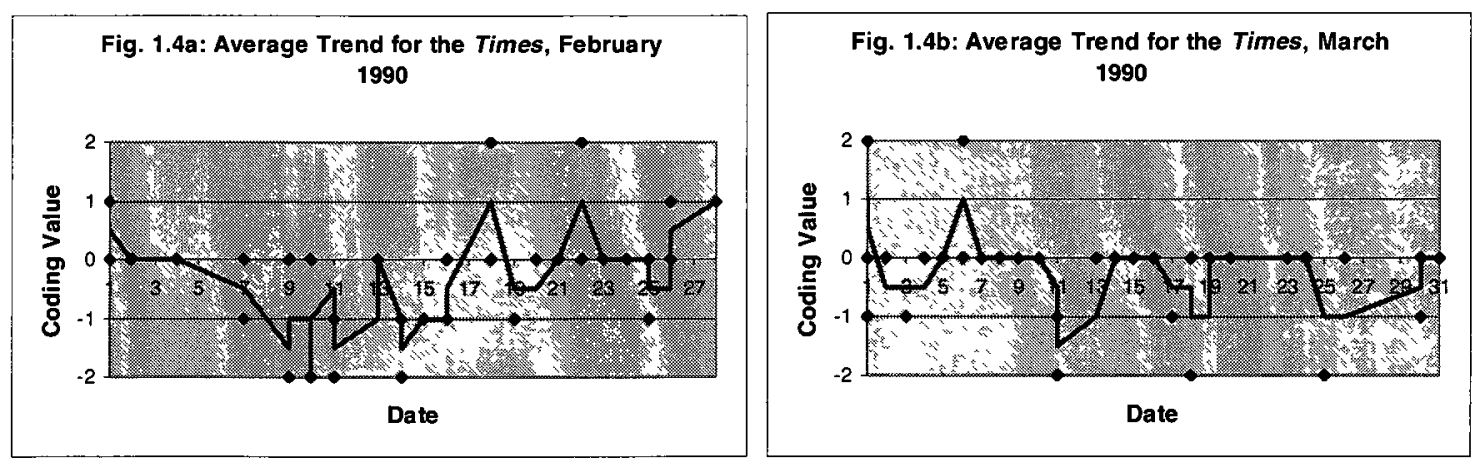

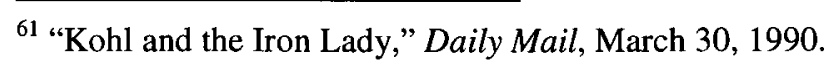


Moving beyond neutral articles, we can see that negative and neutral-negative articles outweighed those that were positive and neutral-positive, allowing us to say that the Times was generally negative in its coverage of Germany during the time period in question. Referring back to Figure 1.2b, we can see that the Times ranked second in terms of percentage of purely negative articles, but first in the percentage of neutral-negative articles. By comparison, there were very few neutral-positive articles ( 3 in total) that relayed positive sayings about Germany. Based on this information, it seems that emphasizing negativity in secondhand reporting was the preferred method used by the more respectable Times to indicate its attitudes towards Germany, in contrast to the tabloid Daily Mail, which preferred to be more blatant. Neutral-negative articles of this sort in the Times usually reported on Margaret Thatcher's anti-German comments, although interestingly this practice stopped rather abruptly around the time of the Chequers-Ridley Affair (considered below).

Articles that were unambiguously negative towards Germany also appeared in sufficient quantity, and often dealt with European security concerns, sometimes tied in with economic considerations. As with the Daily Mail, these articles sometimes contained reference to the Nazi period:

The real danger about German unification is now becoming clear. It is not that a united Germany will become an expansionist military power, continuing where Hitler left off. That is just a fantasy of ignorant politicians and Channel 4 television producers. The real risk is that Germany will imitate Japan, its old Axis ally [in reducing military spending]...German pacifism could destroy Nato and leave Western Europe without any effective protection against the Soviet Union's nuclear might. ${ }^{62}$

Although generally possessing negative attitudes towards Germany, attitudes in the Times showed the greatest amount of fluctuation in the time period in question.

62 "Nato dreads the end of the affair," Sunday Times, March 18, 1990. 
Looking to Figures $1.4 \mathrm{a}$ and $1.4 \mathrm{~b}$, we can see that the generally negative trend turned upwards towards the end of February and beginning of March, before sinking back down. This trend is very interesting, as it seems to be a rather obvious attempt by the Times to appear less anti-German at the time of the Chequers-Ridley Affair, and is in line with Sabine Lee's assertion that this affair prompted more positive (or less negative) views in the British press. ${ }^{63}$ It is at this point that most of the articles that dealt positively with Germany appeared, with one actually referencing Thatcher's actions:

The negative attitude of Mrs Thatcher's government is well on the way to turning a tried friend into a suspicious, anxious and perhaps inward-looking country. It is putting at risk the friendship established between people in the two countries...We should embrace German unity as a demonstration of the self-determination of a people who have given great things to civilization. ${ }^{64}$

This article, and others like it that deal with Germany in positive terms, seem artificial when compared to the usual negative coverage. It becomes clear that Nazi imagery still played a significant role in the Times' view of Germany, even existing in positive coverage:

The federal republic has changed character utterly since 1945 , and she has absorbed the best lessons of British political ways. She has been a great success economically, and denazification has been total. There is nothing whatever to fear from Germany once she is reunited. ${ }^{65}$

This odd tendency towards positive coverage declined as March progressed, and the Times coverage of Germany resumed its negative character.

\footnotetext{
${ }^{63}$ Lee, 205.

64 "Victims of a new prejudice- German reunification," Times, February 22, 1990.

${ }^{65}$ Professor Norman Stone, "No threat from a unified country," Sunday Times, February 18, 1990.
} 

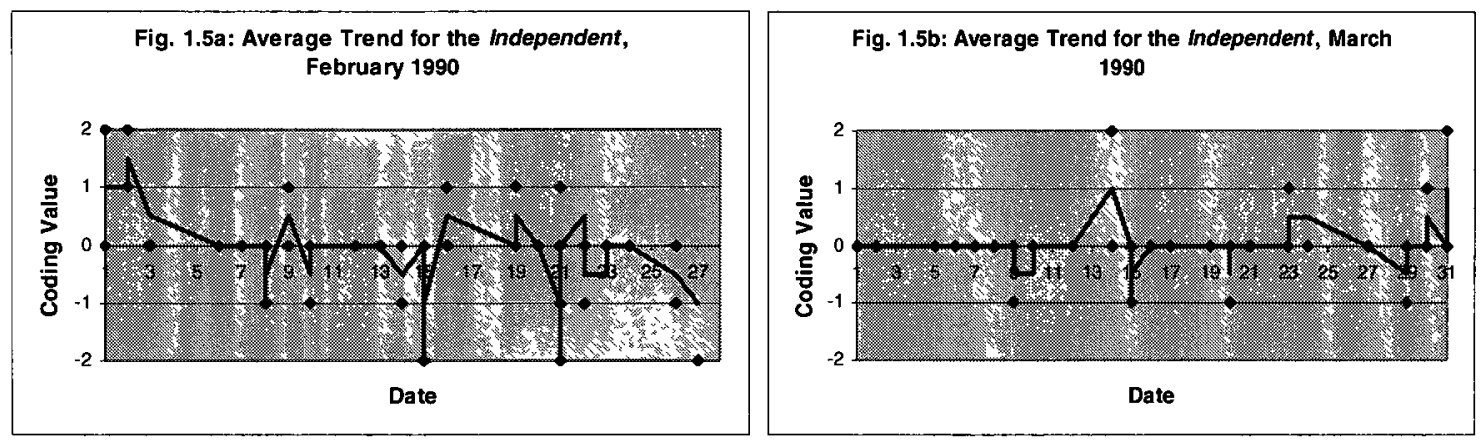

Aside from having the greatest number of articles (102) that dealt with the unification of Germany, the trend of attitudes in the Independent was generally unremarkable. As can be seen from Figures 1.5a and 1.5b, initial positive attitudes towards the unification of Germany quickly gave way to more neutral and negative expressions in the remainder of February, followed by a generally neutral trend in March. Referring to Figure $1.2 \mathrm{~b}$, it can be seen that the percentage breakdown of articles in the Independent was similar to that of the Times, although with slightly less negative coverage. Unlike the Times, where neutral articles tended to centre around the theme of security in Europe in light of German unification, neutral articles in the Independent dealt with a wide variety of issues involved with the unification process, from political speeches, to security and economic considerations. However, neutral-negative articles often lamented the speed of the unification process and the problems it created, while negative articles dealt with the same central theme of security that we saw in the Times:

A neutral Germany would be a bad idea from everybody's point of view. It has superficial appeal as a protection against the militarism of the past, as people instinctively equate neutralism with peace. But a neutral Germany would not be an unarmed Germany...[NATO] memberships involve obligations and impose restraints on the exercise of national sovereignty and are the best protection against a united Germany growing too powerful. ${ }^{66}$

66 “Talks on Reunification," Independent, February 15, 1990. 
This article as well as others also contained reference to past German militarism, which, as we can see, is becoming a central theme in the negative attitudes conveyed in the British press.

One area where the Independent differed from the Times was in its attitude towards the EC, which it regarded as important for containing German power. Several neutral-negative articles lamented the fact that the unification process might cause Germany to ignore the integration process:

There remains lingering concern that, as Bonn diverts its attention to unification, it will have less energy to devote to the Community. Last week, the Belgian EC Commissioner, Karel Van Miert, said that West Germany was already only "paying lip service" to Brussels. ${ }^{67}$

This assertion seems to be borne out by the fact that the majority of articles that spoke of Germany in positive terms also referenced either the EC or Germany's importance in Europe:

A united Germany is the jewel in the crown of a reunited Europe. Geopolitical misgivings are out of date and should be out of court. ${ }^{68}$

The linkage between German unification and European integration constitutes a solid base for optimism. ${ }^{69}$

The Independent, then, contained several of the same negative attitudes towards

Germany that were also contained in the Times. The noticeable difference between the two, however, was the Independent's willingness to discuss Germany in more positive terms in relation to the European Community. The remaining chapters in this study will therefore be able to examine just how far this trend holds.

67 "Delors says unification must be linked to EC," Independent, March 20, 1990.

68 "No time for misgivings about German reunification," Independent, February 1, 1990.

${ }^{69}$ No title, Independent, March 14, 1990. 

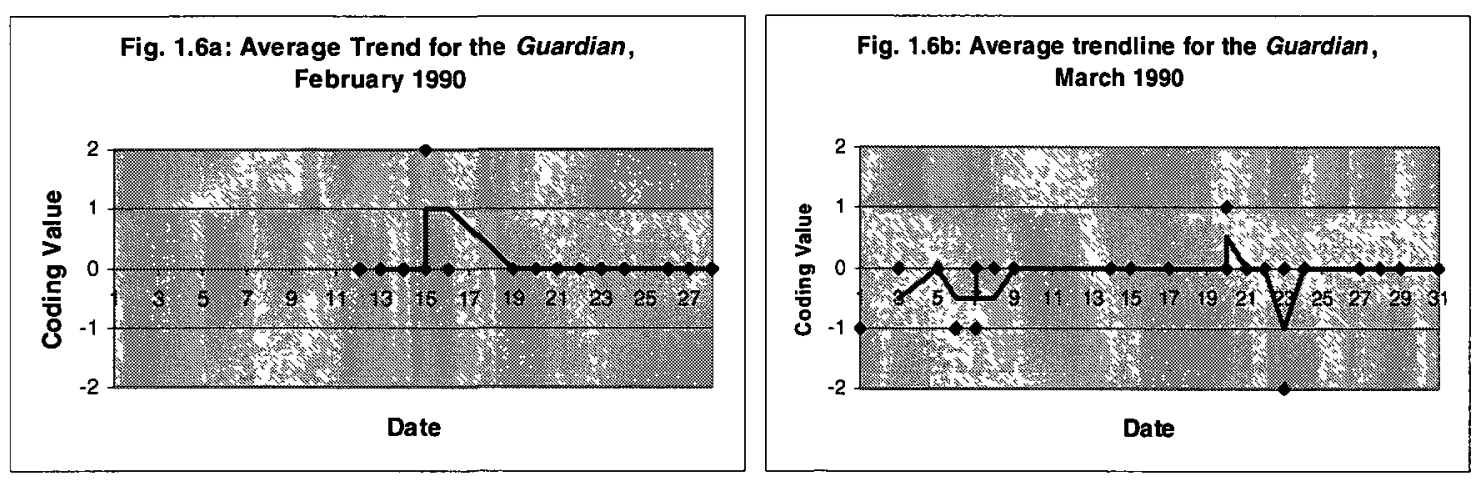

Regarding the attitudes towards German unification contained in the Guardian, the most remarkable aspect for the months in question was the overwhelming degree of neutral articles $(89.5 \%)$. Looking to Figures $1.6 \mathrm{a}$ and $1.6 \mathrm{~b}$, it can be seen that the trend line was remarkably stable over a long period, especially when compared to those of both the Times and Independent. Like the Independent, the neutral articles in the Guardian dealt with a wide variety of topics with no particular emphasis, unlike the focus on security that was evident in the neutral articles of the Times.

Articles that strayed from a tendency towards neutrality were rare and it is therefore difficult to determine common positive or negative themes. The only negative article that appeared in the time period in question did not deal with the character of Germany or Germans, but rather only mentioned that unification was placing "severe strains on the economic system." ${ }^{, 70}$ Likewise, one positive article appeared, stressing a certain amount of faith in Germany with regards to European security, by expressing the idea that "The new Germany and the new Europe will grow up, initially at least, within the outlines of the old arrangements. As they do so, choices that appeared crucial in the past reveal themselves as either not really choices at all or as fundamentally

\footnotetext{
${ }^{70}$ No title, Guardian, March 23, 1990.
} 
unimportant." ${ }^{, 71}$ Like the Independent, this may indicate a tendency in the Guardian to view Germany positively when intertwined with Europe.

Pure neutral-negative and neutral-positive reports were similarly rare, although the former shared a theme in that they tended to deal with the concerns raised by Kohl's actions in the unification process. The relatively low number of either positive or negative articles, combined with the general weakness of comments made in articles coded as either negative or positive, further reinforces the neutrality of the Guardian in its attitudes towards Germany.

Finally, the Economist, despite being the most relatively positive publication in this selection, offers no particularly interesting trends. Like the Daily Mail, it contained relatively few articles (19) during February-March 1990, although the fact that it is a weekly publication rather than a daily can be taken to mean that the Economist had a proportionally greater interest in German unification. This perhaps is nothing groundbreaking, as the focus of the publication is both international news and business. The majority of articles that referenced German unification (14) were neutral, focusing on the process itself or its possible consequences for NATO or the EC. None of the articles made direct negative comments about Germany, while the low number of both the neutral-negative and neutral positive articles tended to contain hypothetical economic consequences of unification, whether positive or negative.

71 "Progress towards unity with the GDR and implications on NATO and defence," Guardian, February 15, 1990. 

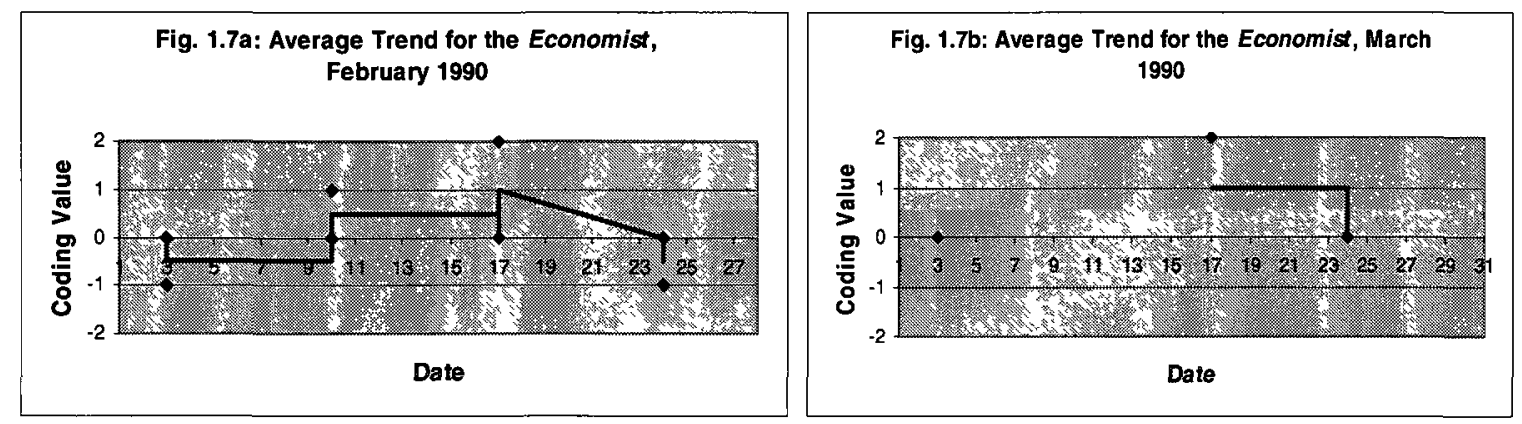

Two positive articles were present, one of which was a reaction against Margaret Thatcher's foreign policy and suggested that German unification would allow Britain to improve links with non-German members of the $\mathrm{EC},{ }^{72}$ while the other indicated a willingness to treat Germany as an equal among nations, "By most of the tests of a civilised life-open politics, lively culture, a plump countryside and peaceful cities-today's Germany makes Hitler's Reich seem a ghost from an inexplicable past." ${ }^{, 73}$ It is interesting to note in this last excerpt that, despite being a generally positive article, the Economist could not resist making reference to Germany's warlike past.

\section{$\underline{\text { Section Conclusions }}$}

By examining British press attitudes towards Germany at the time of German reunification, both in general and specific terms, we are now able to create a tentative basis against which British press attitudes in later chapters can be compared, and further comment on our hypotheses from the introduction. For the most part coverage of Germany reunification was neutral in nature, and once this is discounted, negative attitudes outweigh the positive. This is in line with our hypothesis from the introduction, as well as general scholarly assumptions regarding Germany in the British press.

\footnotetext{
72 "Mrs. Thatcher's foreign policy is leaving the country marooned," Economist, February 17, 1990.

73 "Unification with W Germany should not mean an end to the American connection," Economist, February 10, 1990.
} 
However, as an important qualification to this, we found that this negativity was most often not blatant in nature. While tabloids like the Daily Mail produced stronger, editorial-type articles, the majority of newspapers under examination contained negative reports that were more subdued.

Reviewing the quirks of each particular newspaper further allowed us to examine where specific concerns about Germany lay, and this information will be useful for direct comparisons between the same sources in later chapters. We have seen that common themes shared by these papers included European security concerns in conjunction with growing German power, with common reference to the Nazi period emerging in all manner of articles. We therefore begin to get the sense that Germany exists as a somewhat sinister identity in the British psyche, and the existence of the Germans-asNazis stereotype has been confirmed. It remains for the rest of this thesis to examine how far these findings hold true with regards to German actions in the field of European integration, but for now we may turn to the second portion of this chapter, which examines German press coverage of the British FMD epidemic.

\section{Eye on Britain: The German Press and the British Foot and Mouth Disease Epidemic, February-April 2001}

\section{Background in Brief}

On 19 February 2001, the behavior of livestock at a slaughterhouse in Essex, England, led to the suspicion of an FMD infection, a fact which was confirmed the next day. This immediately led to a ban on the export of British agricultural products, including livestock and meat. At the time of discovery, it is suspected that nearly 60 farms in England were already infected, and from here the disease spread with alarming 
rapidity to infect a total of 44 English counties and also spread to Scotland and Ireland in an epidemic that lasted much of the year. ${ }^{74}$ The disease raged in a near-uncontrolled state in Britain until mid-April, and was not completely stamped out until September.

The scale of the British 2001 FMD outbreak was and remains unprecedented, and to fully understand its nature and its treatment in the German press, more background information is necessary. FMD is a highly contagious virus that affects cloven-hoofed mammals (most importantly sheep, cattle, goats and pigs), causing blisters to appear on the mouths and feet, and leading to crippling and reduced milk production over time. The disease is particularly damaging to farmer livelihood, as it prevents the moving of livestock and the decreased milk production and culling of infected animals often has a negative financial impact. ${ }^{75}$ The disease does not affect humans, who may safely eat the meat of infected animals, or most animals lacking a cloven hoof, although many species, including humans, can act as carriers.

Until 1968, the year in which the last large FMD epidemic was stamped out in Britain, the country had a long history of dealing with periodic outbreaks. After this time, precautionary measures including vaccinations led to a long period of FMD freedom for Britain, and by the 1980s endemic FMD was mostly eradicated in continental Europe as well. ${ }^{76}$ In 1992, the European Council of Ministers changed their recommended policy on FMD policy from preventative vaccination to a slaughter program combined with a ban on infected livestock in the case of an outbreak, thus largely ending the practice of

\footnotetext{
${ }^{74}$ Report by the Comptroller and Auditor General. HC 939: The 2001 Outbreak of Food and Mouth Disease (London: House of Commons, 2002), 2.

${ }^{75}$ Abigail Woods, A Manufactured Plague? The History of Foot and Mouth Disease in Britain (London: Earthscan, 2004), xiii.

${ }^{76}$ Woods, 131-133.
} 
vaccination in Europe. ${ }^{77}$ The British Ministry of Agriculture, Fisheries, and Food (MAFF) placed its faith in the slaughter/product ban method of containment, and paid little attention to other precautions, including developments in new vaccines, for a disease that had been a non-issue for three decades. As a result, the 2001 outbreak (eventually traced to contaminated pig swill) caught British authorities unprepared, a fact that would have implications for the scope of the epidemic. ${ }^{78}$ Following the outbreak in February 2001 , the government instituted a slaughter policy similar to that advised by the European Council of Ministers in 1992. By the end of the epidemic, approximately 6 million animals had been slaughtered in efforts to contain the disease, with close to 10,000 veterinarians, soldiers, and other staff being employed to assist with the crisis at its height. $^{79}$

The sheer size of the epidemic meant that the German press reported on it regularly from the time of the outbreak in late February until the situation improved in late April, and these months therefore provide the timeframe examined in this chapter. Coverage during this period tended to alternate between the situation in England and worries of a similar outbreak in Germany. However, despite concerns of an outbreak on the European mainland, only scattered cases emerged in France and the Netherlands. ${ }^{80}$ Armed with this information, It is now fitting that we turn to how this event was handled in the German press.

\footnotetext{
${ }^{77}$ Woods, 134.

${ }^{78}$ Woods, 137.

${ }^{79}$ Report by the Comptroller and Auditor General. HC 939: The 2001 Outbreak of Food and Mouth Disease (London: House of Commons, 2002), 2.

${ }^{80}$ Woods, 138.
} 
Newspaper Coverage and Interpretation Overall

The data upon which this section is based comes from a total of 162 articles from the five previously-mentioned German national newspapers. Figure 1.8 shows how this information compares overall, while Figures $1.9 \mathrm{a}$, and $1.9 \mathrm{~b}$ display the breakdown per paper.

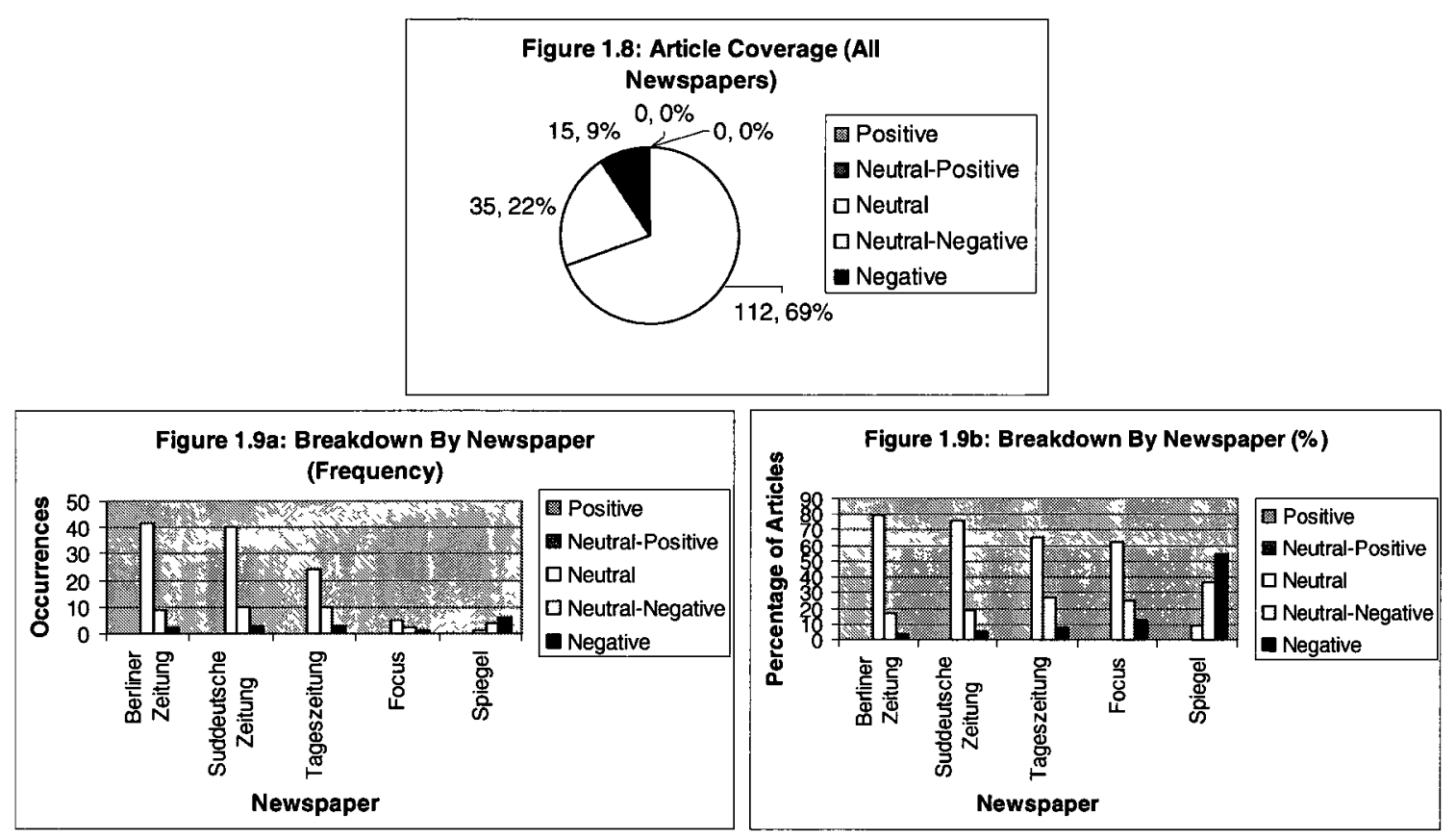

As is to be expected, Figure 1.9 a tells us that the most articles were run by daily papers, while the weekly publications had relatively few, much the same as in the British case. By itself, this data tells us five things about German press attitudes regarding the British.

\section{1) The majority of press coverage was neutral.}

Looking at these figures, we can see that the majority of articles concerning Britain and the FMD were neutral in nature, with Figure 1.8 showing $69 \%$ of all articles being coded as such. Moving to Figure $1.9 \mathrm{~b}$, we can see that, with the exception of Der Spiegel, all of the newspapers under comparison were broadly proportional in their coverage. The 
difference between the high and low values for the neutral coverage for the remaining four papers was relatively low at $16.7 \%$, with the Berliner Zeitung and Süddeutsche Zeitung comparing at $79.2 \%$ and $75.5 \%$ respectively, while the Tageszeitung and FOCUS were also similarly proportional at $64.9 \%$ and $62.5 \%$. As in the British case, this high number of neutral articles is to be expected as a result of the passive relay of information.

\section{2) There are no positive articles to be found.}

None of the five newspapers under examination contained articles that cast Britain in a positive or even semi-positive light. This is an interesting finding, and it conflicts with the hypothesis put forth in the introduction, which predicted more negativity in the British press than German. Explanations as to why this is the case will remain purely hypothetical until the test data for later cases is analyzed. It is possible that the German press runs few positive articles in general, or that it is generally negatively disposed towards Britain, or that merely there was little positivity to be drawn from the disease epidemic. In any case, this point leads directly into the next:

3) When neutral articles are discounted, press coverage was entirely negative.

Given the absence of positive or neutral-positive articles, the remaining articles which are not neutral are necessarily negative in nature. Recalling the hypotheses from the introduction, it was predicted that both press groups would contain more negative reporting than positive, although this extent of negativity in the German press was not expected. Looking to Figure 1.8, we can see that at $31 \%$, negative and neutral-negative articles make up almost a third of the total coverage, although, as mentioned above, the exact reasons for this is not obvious. 
4) This negativity was rarely blatant.

With Der Spiegel once again being taken as the exception, we can see that neutralnegative reports always outweighed the purely negative by a factor of at least two to one.

This was the case with the coverage in FOCUS, which ran in total one negative article and one neutral-negative. The remaining newspapers, the Berliner Zeitung, the Süddeutsche Zeitung, and the Tageszeitung, all carried at least three times as many neutral-negative articles than purely negative. Although no pre-existing assumptions about negativity in the German press exist, this finding still sheds light on the manner of its presentation.

5) We can determine a scale of relative negativity for these newspapers.

Among the five German sources, Der Spiegel was the most unambiguously negative, with the percentage of negative and neutral negative articles (54.5\% and $36.4 \%$ respectively) dramatically outweighing the neutral $(9.1 \%)$. The remaining four newspapers were much closer to each other in their proportional negativity, with a difference of no more than $10 \%$ separating the high and low values for both negative and neutral negative article coverage. ${ }^{81}$ In order of decreasing negativity, the scale therefore goes Der Spiegel with an overall $90.9 \%$ of articles coded as negative or neutral-negative, followed by FOCUS with $37.5 \%$, the Tageszeitung close behind with $35.1 \%$, the Süddeutsche Zeitung with $24.6 \%$ and finally the Berliner Zeitung with $20.8 \%$. The political partisanship of each newspaper does not appear to have played a part in this scale. Through these findings, we have formed a general basis against which later cases

\footnotetext{
${ }^{81}$ In negative articles, FOCUS is proportionally the highest with $12.5 \%$, and the Berliner Zeitung the lowest with $3.8 \%$. For neutral-negative articles, the Tageszeitung is proportionally highest with $27 \%$, and the Berliner Zeitung is again the lowest with $17 \%$.
} 
may be compared. The task now is to look at coverage in each of the five newspapers individually, in order to determine if common trends or themes concerning Britain and the British were present in German press coverage.

Individual Trends and Themes

Let us begin the examination of individual newspapers by examining Der Spiegel, which has been referenced numerous times already as the exception to otherwise similar trends. No articles concerning both FMD and Britain were run during the month of February 2001, so the data for this section comes from March and April.
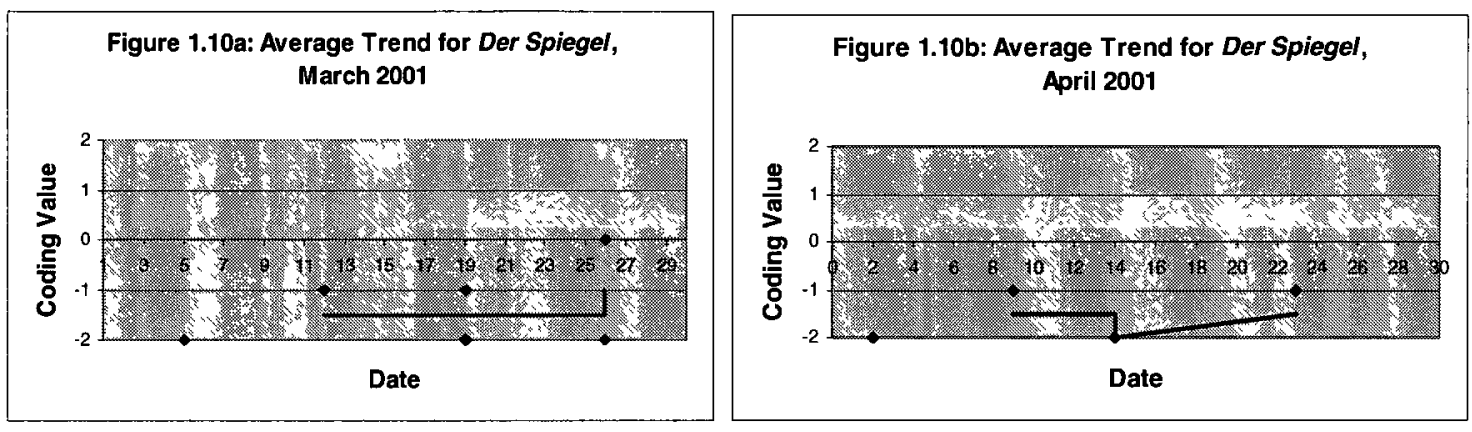

The most fascinating finding from Der Spiegel is that, while there were relatively few articles run (11 in total), they were mostly unambiguously negative. The number of openly negative articles (6) outnumber the number of neutral and neutral-negative articles combined ( 4 and 1 respectively), in a trend that is the complete inverse of the other 4 newspapers under examination, where the number of neutral articles always outnumbered the neutral-negatives, and the neutral-negatives outnumbered the openly negative. One can further see from Figures $1.10 \mathrm{a}$ and $1.10 \mathrm{~b}$ that the trend line carried an approximate average value of -1.5 , beyond the neutral-negative coding value of -1 . In fact, the lone neutral article was not extensively devoted to an examination of FMD and Britain, but merely made a passing reference to the experiences in England. 
The neutral-negative articles in Der Spiegel all carried a similar theme, in that they were devoted to indirectly criticizing British control measures or painting a rather dark picture of the situation caused by the epidemic. In the former case, a Spiegel interviewee commented that, in case of an outbreak in Germany:

There will be no funeral pyres [for slaughtered animals]. That is forbidden for reasons of environmental protection, and is, in fact, not effective. What is happening over in England is terrible. The soil under such burning places is contaminated with diesel oil for years to come. ${ }^{82}$

While neutral-negative articles were by no means flattering to England and the English, the negativity was at least indirect, either being supplied by a non-Spiegel source or by implication only. However, as previously mentioned, Der Spiegel did not often rely on indirect negativity in order to get its point across, preferring instead to take a strong editorial stance on the events in England. Some of the comments made by those articles coded as purely negative were particularly withering, blaming the British as the culprits behind the disease, or suggesting incompetence in its handling. One particularly noteworthy article states:

London's chaotic battle against Foot and Mouth Disease has revealed that Tony Blair's attempt to modernize the United Kingdom was no more than an advertisement. Complacency, inefficiency, and narrow-mindedness still dominate the land. ${ }^{83}$

Interestingly, Der Spiegel also made relatively frequent use of anti-British stereotypes in its negative articles, something which was generally not found in the other newspapers under examination. This can be seen to some degree in the previous excerpt, which noted

\footnotetext{
82 "Die Tiere leiden schrecklich," Der Spiegel, March 12, 2001. German: Scheiterhaufen wird es nicht geben. Das ist aus Umweltschutzgründen verboten und im Übrigen auch nicht effektiv. Was sich da in England abspielt, ist furchtbar. Der Boden unter solchen Brandstellen ist auf Jahre hinaus mit Dieselöl kontaminiert.

83 "Der englische patient," Der Spiegel, April 14, 2001. German: Londons chaotischer Kampf gegen die Maul-und Klauenseuche offenbart: Tony Blairs Versuch, das Vereinigte Königreich zu modernisieren, hat sich in Ankündigungen erschöpft. Selbstgefälligkeit, Schlendrian und Krämergeist beherrschen nach wie vor das Land.
} 
the "narrow-mindedness" of the land. This notion that the British are an eccentric people appeared, "even more dramatic is the situation in the FMD stronghold of Great Britain. Above all the equestrian events, always popular among the English, can hardly be found." 84 The pride of the British people was also mocked in an article which stated "proud Britain no longer has enough experts to help herself," 85 and one final article commented on the tendency of the British towards self-pity and blame-shifting:

Given [the FMD situation], the English are tending, as usual, towards self-pity: the Daily Mail identifies the British as the "Pariahs of Europe"...It is no wonder that the British are once again making out foreign countries to be the authors of the debacle. ${ }^{86}$

It can therefore be said that Der Spiegel was negatively disposed towards Britain and the British at the time of the FMD outbreak, and the newspaper did not shy away from negative stereotypes in order to highlight perceived shortcomings. However, it remains to be seen if this negativity was merely because of the FMD situation in Britain, or if the newspaper is negatively disposed towards Britain and the British in a broader sense. It will also be interesting to see if similar stereotypes emerge in focal points concerning Britain and European integration.

The next newspaper to be considered here is FOCUS. As with Der Spiegel, coverage of the outbreak of FMD in Britain did not begin in FOCUS until March 2001, so data for this section was drawn from the months of March and April.

\footnotetext{
84 "Athleten im Sperrbezirk," Der Spiegel, April 14, 2001. German: Noch dramatischer ist die Lage in der MKS-Hochburg Großbritannien. Vor allem die bei den Engländern so beliebten Military-Prüfungen, die in der freien Natur ablaufen, finden kaum noch statt.

85 "Dann machen wir euch dicht," Der Spiegel, March 26, 2001. German: Das stolze Britannien hatte nicht mehr genug Experten, um sich selbst zu helfen.

86 "Ruin im Sperrbezirk," Der Spiegel, March 5, 2001. German: Angesichts dieser Kettenreaktion neigen die Engländer wie meistens zum Selbstmitleid: Als "Parias Europas" identifizierte die "Daily Mail" ihre Landsleute...Kein Wunder, dass die Briten wieder einmal das Ausland als Urheber des Debakels ausmachen.
} 

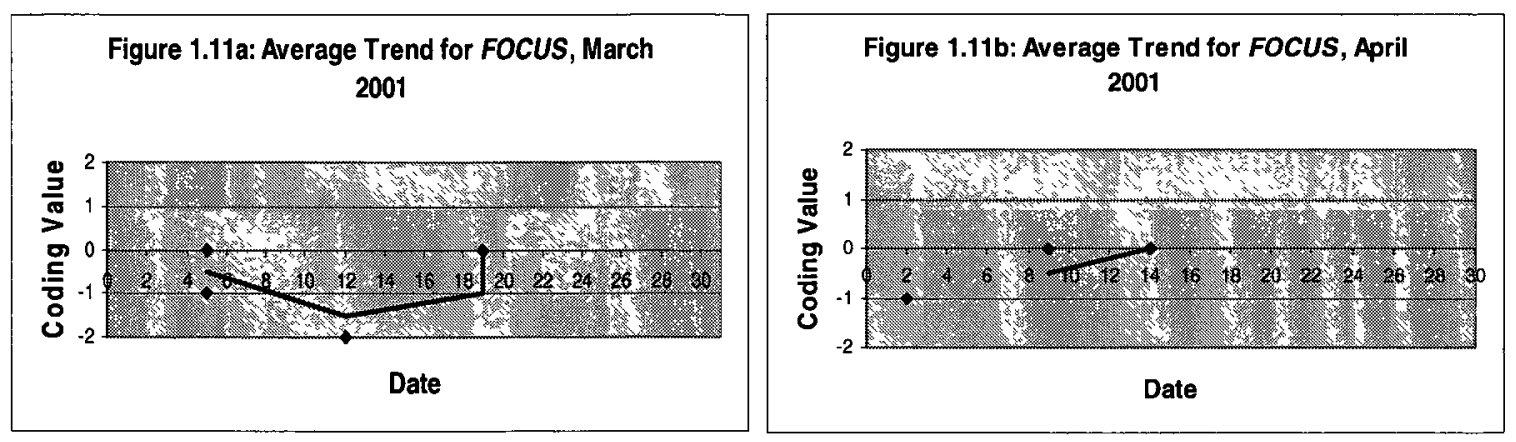

Compared with Der Spiegel, FOCUS' coverage of the FMD epidemic was generally unremarkable. In the two months under examination here, the newspaper ran only 8 articles that contained reference to both Britain and FMD, making any long-term trends difficult to discern. Of these articles, five were neutral, two were neutral-negative, and one was negative. Referring back to Figure $1.9 \mathrm{~b}$, we can see that the article breakdown in FOCUS was similarly proportional to the coverage in all newspapers except Der Spiegel, and almost identical to that of the Tageszeitung. The neutral articles dealing with FMD and Britain in FOCUS tended to cover the usual topics that one might expect from the coverage of a disease epidemic, with the majority ( 3 articles) discussing the spread of FMD and new cases that had emerged. The two remaining neutral articles discussed the history of the FMD outbreak and the decision of the British government to postpone the general election in light of the outbreak.

Although FOCUS was proportionally one of the more negative newspapers under examination here, it is perhaps important to note that this negativity seemed to arise more from the tendency of the newspaper to occasionally resort to exaggerated or sensational language, as opposed to any real anger or annoyance with Britain or the British. Both articles coded as neutral-negative might otherwise have been coded neutral if not for the seeming desire to make the situation in Britain appear hellish or hopeless. An article from 
March 5 noted that "the British feel cursed by God...for many farmers are fighting for a bare existence," $" 87$ while one from April 2 stated "Food and Mouth Disease is out of control. It has already damaged tourism and affected the election date...The British are set to lose the battle against FMD." ${ }^{, 8}$ It is even possible that the only article coded as negative was intended to be humorous, although the words themselves appear negative: "After BSE, TBC, and FMD, all unpleasantness seems to have three letters and come from either Great Britain or Bavaria." ${ }^{, 89}$

Compared to the articles collected from Der Spiegel, it is therefore obvious that FOCUS contained much less genuine negativity. Stereotypes of the sort found in Der Spiegel were absent, as were direct attacks on Britain and the British. Negativity came more through the use of emotional language, and all of it stemmed directly from the FMD situation. It is perhaps not too rash to hypothesize that FOCUS, due to its lack of resort to negative stereotypes, is generally neutrally disposed towards Britain and the British.

As previously mentioned, the article breakdown in FOCUS was quite similar proportionally to that of the independent daily Tageszeitung. The Tageszeitung did run one article on the FMD situation in February, but since there were no others, and because the article was coded as neutral, the data for this section once more comes only from the months of March and April 2001.

\footnotetext{
87 "KRISE- Dort, wo die Seuche tobt," Focus, March 5, 2001. German: Die Briten fühlen sich von Gott verflucht...Denn viele Bauern in Großbritannien kämpfen um die nackte Existenz.

88 "Grossbritannien- Ein Virun regiert das Land," Focus, April 2, 2001. German: Die Maul-und Klauenseuche ist außer Kontrolle. Sie schadet bereits dem Tourismus und beeinflusst sogar den Wahltermin...Die Briten sind dabei, den Kampf gegen das MKS-Virus zu verlieren. 89 "Spruche- Nach BSE," Focus, March 12, 2001. German: Nach BSE, TBC und MKS scheint alles Unangenehme drei Buchstaben zu haben und aus Großbritannien oder Bayern zu kommen.
} 

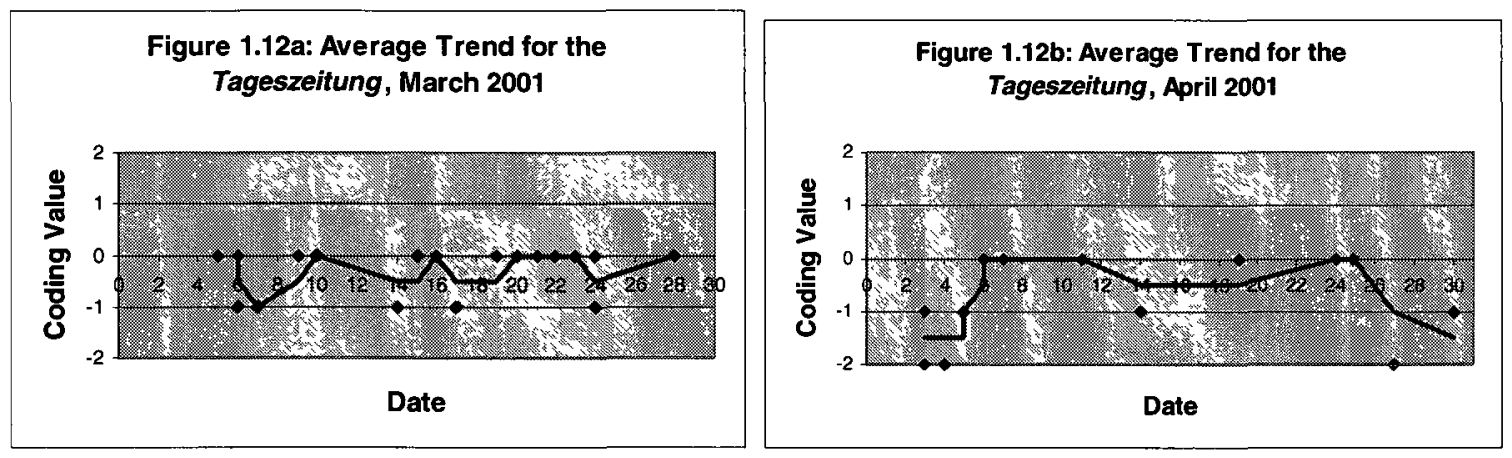

As can be seen from figures $1.12 \mathrm{a}$ and $1.12 \mathrm{~b}$, the Tageszeitung generally fluctuated between neutral and neutral-negative articles in March and for much of April, with more negative stories appearing at the beginning and end of the latter month. As previously mentioned, this newspaper was approximately equal to FOCUS in its proportionally high negativity, with $64.9 \%$ of articles being coded as neutral, $27 \%$ as neutral-negative, and $8.1 \%$ as wholly negative.

In terms of neutral stories, the Tageszeitung reported on similar topics as the other newspapers under examination, such as the spread of the disease, the cullings in England, the movement of animals and immunization measures, but it did not report on them with the same frequency as the Berliner Zeitung and Süddeutsche Zeitung. Most of the neutralnegative stories, which made up the majority of the negative coding for the Tageszeiting, carried a similar theme in that they tended to criticize British disease control procedures, generally through interviews or indirect reports. In both of these cases, the negativity came from non-Tageszeitung sources. For example, an interviewed German farmer was noted as saying "when I see the many British FMD pyres on the evening television, I can only switch it off. Now it turns out that the mass graves of culled animals threaten the 
groundwater there. That is madness." 90 Some reports were indirectly critical of British procedures, for example by noting that "Ireland is far more vigorous in fighting the disease than Britain."91

The negative dips in the graph at the beginning and end of April were not in response to events in the course of the epidemic that were more important to others; they were merely cases when criticism of disease control was more direct than the usual neutral-negative method. The first of these singled out Tony Blair and criticized his handling of the crisis. The second noted an outbreak of FMD on the continent and complained that "the British recognized the virus much too late." 92 The final article at the end of April lamented the millions of animals that "found a miserable end on British pyres,"93 while further noting that a white calf named Phoenix had escaped his British butchers. As a closing note on the Tageszeitung, we can further note that, like FOCUS, all of the negative articles were directly related to the FMD outbreak, and that no stereotypes regarding Britain or the British were encountered. This would seem to indicate that, while we have seen Germany portrayed in sinister terms in Britain, there is no similar apprehension of Britain in the German psyche.

The last two newspapers under consideration, the Berliner Zeitung and Süddeutsche Zeitung, are examined together here, because of their significant similarities. Both newspapers began their coverage of the FMD outbreak in late February, and

\footnotetext{
90 "Wir leiden an den Altlasten," Tageszeitung, April 14, 2001. German: Und wenn ich abends im Fernsehen die vielen britischen MKS-Scheiterhaufen sehe, dann kann ich nur noch abschalten. Nun zeigt sich, dass die Massengräber gekeulter Tiere dort das Grundwasser gefährden: Das ist der pure Wahnsinn. 91 "Irland bekampft den Tierschmuggel," Tageszeitung, April 30, 2001. German: Irland geht weit rigoroser als Britannien gegen die Seuche vor.

92 "Verdacht ganz hart," Tageszeitung, April 4, 2001. German: Briten haben Virus viel zu spät erkannt

93 "Was feht," Tageszeitung, April 27, 2001. German: Während mehr als zwei Millionen Tiere auf britischen Scheiterhaufen ein klägliches Ende fanden, entkam das kleine weiße Kalb Phoenix seinen Schlächtern.
} 
followed its spread until mid-March. During this time, each newspaper ran 53 relevant articles, and referring once more to Figure $1.9 \mathrm{~b}$, we can see that the article breakdown of each paper was almost identical. The majority of neutral articles in both newspapers concerned the spread of FMD in Britain and the culling methods that were employed there, although the Sïddeutsche Zeitung differed from the Berliner Zeitung (and all other newspapers under examination here) in that it routinely commented on FMD's impact on sports. Additionally, each newspaper reused the phrase "raging disease" $" 94$ numerous times in these articles. Looking to the following figures, we can see that the only real difference between the newspapers' coverage was the differing dates of the neutralnegative articles, with the Süddeutsche Zeitung concentrating such reports during the month of March, while the Berliner Zeitung spread them out throughout the months of March and April.
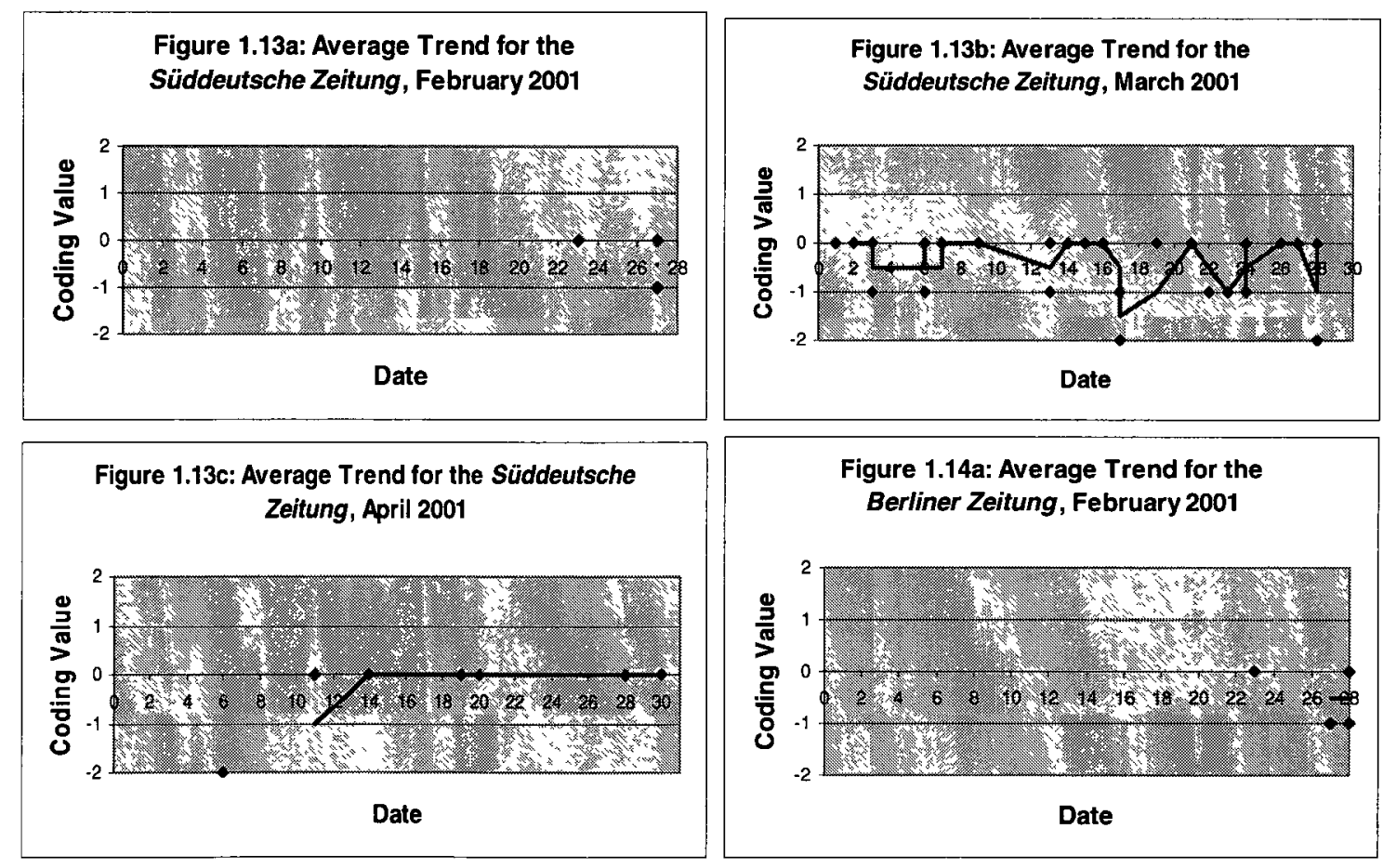

\footnotetext{
${ }^{94}$ German: grassierende Seuche
} 

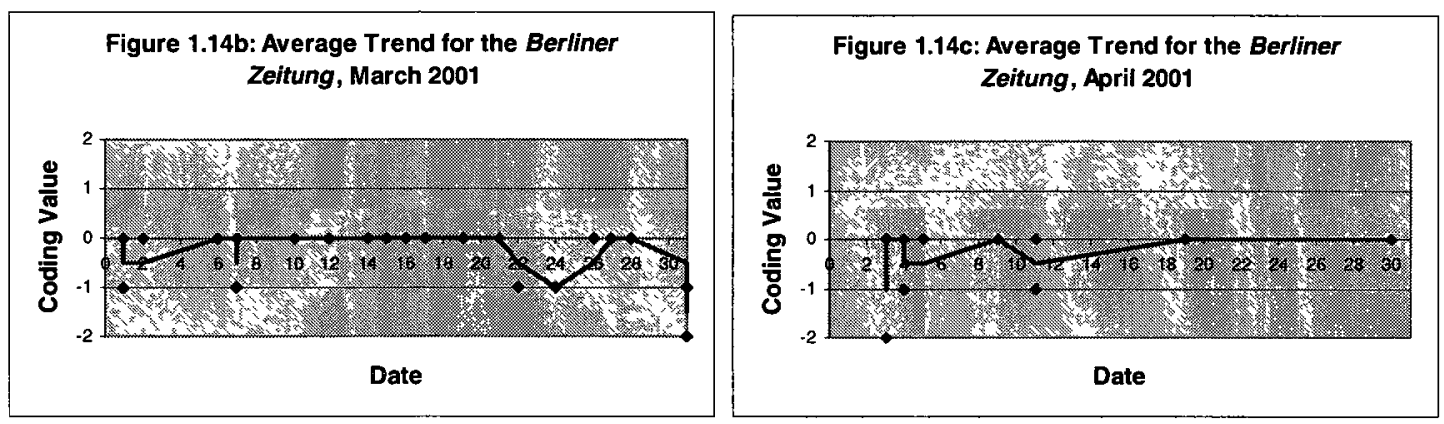

Like the neutral-negative articles in the Tageszeitung, such reports in the Berliner Zeitung and Süddeutsche Zeitung most often contained indirect criticisms of British disease control methods, using reports from third parties or implications to get the point across. The similarities that these types of reports bear, not only to each other, but to those in the Tageszeitung, make the use of additional examples here unnecessary.

Although the Berliner Zeitung and Süddeutsche Zeitung were rarely blatantly negative, with the former having only $3.8 \%$ of its total articles conform to the given definition, and the latter $5.7 \%$, these articles nonetheless deserve consideration. In the case of the former newspaper, the negativity did not appear to be deep-seated. One article was coded as negative rather than neutral negative because of its vivid language, which referred to the "British apocalypse" and the destruction of the countryside in England, ${ }^{95}$ while the other contained moderate though direct criticism of the British government, stating that "If [Blair's] government does not succeed in getting a better grip on FMD than it has so far, it is expected that the election in June will mutate into a censure vote. ${ }^{96}$

\footnotetext{
95 "Die Ställe sind für Touristen tabu - Eingefleischte Bauernhof-Fans buchen dennoch," Berliner Zeitung, March 31, 2001.

96 "Tony Blair geht auf Risiko," Berliner Zeitung, April 3, 2001. German: Wenn es seiner Regierung nicht gelingt, die Maul-und Klauenseuche bis Mitte Mai deutlich effizienter in den Griff zu bekommen als bislang, dann dürfte der Urnengang im Juni zu einer Misstrauensabstimmung mutieren.
} 
The negative articles in the Süddeutsche Zeitung, however, seemed slightly more sinister. Although only three of these articles were coded as directly negative, all of them contained hints of a slightly cooler attitude towards Britain and the British. One article run on April 6 bluntly referred to Britain as "the source of the calamity." $" 97$ The two remaining articles also contained, like Der Spiegel, a willingness to stereotype the British. The first article of this type, tellingly called "Drink Tea and Persevere," incorporated the stereotype of soccer hooliganism with the sinister notion that the English are plague-bearers:

The English fans could possibly have brought something completely different from their pugnacity. Bacon provisions, shoe soles and clothing could hide that virus that has fuelled the fires of the pyres on the island for weeks: FMD. ${ }^{98}$

The last of the three coded as negative criticized the "lax British control of animal feed," and poked fun at the British and their "vaunted splendid isolation, that often takes, in times of crisis, the character of sacred isolation." ${ }^{.99}$ The same article also referenced the British as animal-lovers. These articles show a willingness to resort to stereotypes, indicating that perhaps the Süddeutsche Zeitung takes a more negative view of Britain and the British than does the Berliner Zeitung, where such stereotypes were absent. It should be noted, however, that the Süddeutsche Zeitung was generally inclined to voice its negativity in an indirect way via neutral-negative articles, and that negative articles containing stereotypes made up only 3 of 53 articles.

\footnotetext{
97 "Impfung nur im Notfall," Süddeutsche Zeitung, April 6, 2001. German: Ausgangsort der Kalamitäten.

98 "Tee trinken und durchhalten," Suddeutsche Zeitung, March 17, 2001. German: Möglicherweise könnten die englischen Fans noch etwas ganz anderes mitgebracht haben als ihre Rauflust. Versteckt im BaconProviant, an Schuhsohlen und in den Kleidern könnte sich jener Virus verstecken, der seit Wochen die Scheiterhaufen auf der Insel befeuert: MKS, Maul-und Klauenseuche 99 "Gelbe Gefahr," Sïddeutsche Zeitung, March 28, 2001. German: Großbritannien ist lange gut gefahren mit seiner viel beschworenen splendid isolation, die gerade in Zeiten der Krise häufig den Charakter einer sacred isolation annimmt.
} 
$\underline{\text { Section Conclusions }}$

Having examined five major German newspapers and their coverage of the British FMD outbreak, we have been able to create a tentative basis against which German press attitudes towards Britain and the British in later chapters can be compared, and we have further provided some new information on how the German press reports on Britain. We have generally found that the majority of German articles that dealt with Britain were neutral, as is to be expected, although we have also found that, when these neutral articles were discounted, the remainder was purely negative. Whether this is a result of a general trend in German press reporting, or whether it was specifically the case for reports on the FMD outbreak, is unclear. As a qualification however, this negativity was found to be rarely direct, and we have seen how neutral negative articles tended to heavily outweigh the purely negative articles in most newspapers.

By examining individual newspapers, we have been able to determine a number of quirks as well. Newspapers such as Der Spiegel and the Süddeutsche Zeitung have indicated a tendency to resort to stereotypes in their negative articles, although the majority of newspapers have not, suggesting that Britain does not factor as large in the German psyche as in the reverse case. Much of the negativity that came from FOCUS seemed to be more due to a tendency to use sensational language than to any real deepseated anger or annoyance with the British. In terms of common trends, most of the neutral-negative reports between the five newspapers concerned the handling of the disease by the British, which could suggest that the generally negative disposition of the German press towards Britain was, in this case, dependent on the situation. 


\section{Chapter Findings: The British and the German Press}

Using the information that has been gathered in this chapter on both the British and German press, we may now make some comparisons and draw tentative conclusions about how each group reports on the other country outside the field of European integration. These findings will be used as a basis against which the following chapters that deal with events in the history of European integration will be compared, so that differences or similarities in press coverage in this particular situation can be observed. Regarding events not concerning European integration, we can say:

\section{1) Both the British and German press run a similar proportion of neutral articles.}

Despite the fact that some newspapers (notably Der Spiegel, the Guardian, and the Daily Mail) contained neutral article counts that were proportionally much higher or lower than the other newspapers under examination, the overall average for neutral articles found in both the British and German press was similar. In the first case, the average proportion of neutral stories run in the five newspapers examined was $68.5 \%$, while in the latter case the number was $58.24 \%$, a difference of only about $10 \%$. Paying attention to the proportion of neutral articles run during events concerning European integration will allow us to gauge how much emotion, relatively speaking, that the topic elicits in both countries. A higher neutrality count will theoretically speak to a more passive interest, while a lower count will suggest that the topic is more volatile. 
2) While neither country's press is favorably disposed towards the other country, the German press is proportionally the more negative of the two.

We have seen from the data gathered in this chapter that, while the British press tended to run more negative articles than positive, the German press did not tend to run any manner of positive articles at all. While the overall percentage of negative articles run in the British press was $19.6 \%$, the value in the German press was $31 \%$. This conflicts with our hypothesis from the introduction, although the findings from the German section of this chapter seem to suggest that the high negativity count here was because of the negative situation caused by the FMD outbreak.

3) The negativity in both countries' newspapers was generally not blatant.

With the exception of the Daily Mail in the British press and Der Spiegel in the German press, use of a 5-point coding methodology has allowed us to break down the notion of "negativity" and shown us that all newspapers contained more neutral-negative articles than negative, meaning that general negativity was more likely to be subdued (appearing as reports on negative happenings, or as an undercurrent) than blatant (editorial or specifically emphasizing a negative factor).

4) The British press is more inclined to use stereotypes.

While we have seen that certain German newspapers, such as the Sïddeutsche Zeitung and Der Spiegel are inclined to use British stereotypes, this phenomenon appears to be more widespread in the British press, where four of the five newspapers have been shown to use stereotypes to some extent. As previously mentioned this would seem to indicate that the image of Germany factors larger in the British psyche than the image of Britain 
does in the German. Additionally, we have seen that, while images of a militaristic or Nazi Germany in Britain tend to inspire apprehension or fear, images of Britain in Germany tend to emphasize the eccentricity of the British, painting them as isolationists, tea-drinkers, or soccer hooligans. The quantity of newspaper articles (276 British to 162 German) would also seem to indicate a greater British interest in Germany than in the reverse case. This last finding is in line with the hypothesis from the introduction.

\section{5) It seems that the British press has more potential to be directly negative than the} German press.

A re-examination of Figures 1.1 and 1.8 tells us that the total percentage of negative articles in the British press was $8 \%$, only slightly below the German press' $9 \%$. Given the extreme negativity of Der Spiegel, the ambiguous negativity of FOCUS, and the generally negative nature of the FMD breakout overall, it is not hard to imagine that the proportion of directly negative articles in the German press is slightly skewed. This would go some way towards redeeming our hypothesis that the British press is the more negative of the two. However, the German press is still clearly the more indirectly negative of the two (and still the most negative overall), having of total of $22 \%$ neutralnegative articles to the British press' $12 \%$. Finally, as a point of interest:

6) There seems to be little correlation between negativity and a newspapers' political affiliation.

While we may later find that a newspaper's attitudes towards the opposing country is coloured by its attitudes towards European integration or a given event, attitudes do not seem to be affected merely by a newspaper's position on the political spectrum. In the 
British case, the Times as well as the Economist have shown opposing attitudes to Germany despite both being conservative publications, while in the German case, the right-wing FOCUS has been shown to be similar in its attitudes to the left-wing Tageszeitung.

Having examined press attitudes and drawn some tentative conclusions in cases not directly dealing with European integration, we may now move forward with the main task of this project: to determine the nature of press attitudes towards the opposing country in the European integration project. The following chapters examine press coverage of three events in the history of European integration: the Treaties of Amsterdam and Nice, as well as the ultimately failed attempt to create a constitution for the European Union. The information collected on these topics will be compared and analyzed, with the data from this chapter will provide benchmarks against which the findings in future chapters will be compared, hopefully serving to draw out particular nuances that might not be obvious otherwise. 


\section{Chapter 2: Anglo-German Press Attitudes during the Amsterdam and Nice Summits}

Having looked at the press coverage of certain events outside the field of European integration in order to establish a baseline against which other information may be compared, we may now begin our examination of Anglo-German press attitudes in the field of European integration. For the sake of easier comparison, and also because of the relatively light press coverage of both focal points (especially compared to that of the European Constitution examined in the next chapter), both the Amsterdam and Nice summits are examined concurrently in this chapter. In each case, the time period from which press coverage is drawn is two months; in the case of the Amsterdam summit this is May-June 1997 (the month of the conference itself and the month preceding it), and for the Nice summit it is December 2000 (the month of the summit) and June 2001 (the month of the treaty's rejection in an Irish referendum). In terms of layout, this chapter is arranged in a similar manner as the last, beginning with a section containing some background information and moving to an examination of English press attitudes, which is then followed by a similar section concerning the German sources. The final section compares the findings from each case and draws some conclusions about the press attitudes of each country concerning the other in the European integration project.

\section{Background Information}

\section{The Summits}

The summits at Amsterdam (16-18 June 1997) and Nice (7-10 December 2000) both concluded lengthy intergovernmental conferences (IGCs) concerning European integration and eventually produced the Treaties of Amsterdam and Nice. These 
contained respectively the first and second round of amendments made to the Treaty of Maastricht, which had created the European Union upon its coming into force on 1 November 1993. In terms of the scope of the envisioned changes, Amsterdam was the greater of the two. The IGC and concluding summit were primarily concerned with reforms to be made to European institutions in order to prepare for the expansion that would take place as countries from the former Eastern Bloc joined the EU, but they also aimed to measure the progress that European integration had made since the Maastricht Treaty and attempted to take steps towards the further political integration of member states. ${ }^{100}$ In the event, there was little agreement reached on various issues during the IGC, which had the effect of leaving many contentious issues to be discussed at the final summit. ${ }^{101}$ In Amsterdam, while numerous policies were developed concerning areas such as asylum, visas, and border controls, and agreements were made in the field of EU foreign policy, the summit generally failed to meet the expectations that had been set. Little was achieved concerning further political integration, and only modest modifications were made to the structure of the EU to allow for Eastern enlargement. ${ }^{102}$ The resulting Treaty of Amsterdam was signed in October 1997 and came into effect in May 1999.

In February 2000, a new IGC round began, the purpose of which was to concentrate on the institutional issues that had not been resolved at Amsterdam. Major areas of focus included the future composition of the European Commission and

\footnotetext{
${ }^{100}$ John McCormick, Understanding the European Union: A Concise Introduction (New York: Palgrave Macmillan, 2005), 74.

101 Jan Grunhage, "The 1996/97 Intergovernmental Conference: A Survey of the Process," in The European Union after the Treaty of Amsterdam, ed. Jörg Monar and Wolfgang Wessels, 9-30 (New York: Continuum, 2000), 21.

${ }^{102}$ McCormick, 74.
} 
European Parliament, as well as the redistribution of votes in the Council of Ministers, the last of which proved to be one of the most contentious issues. Other important areas concerned reform of the European Court of Justice and discussions on the Common European Security and Defense Policy. ${ }^{103}$ The IGC efforts culminated in the December 2000 Nice summit which produced the Treaty of Nice. ${ }^{104}$ After its signing in February 2001, the Treaty of Nice was initially rejected by Ireland in a referendum in June 2001 due to the belief that it would cause the surrender of too much national control to European bodies. The issue was clarified, and the treaty was then accepted by the Irish in another referendum in October of the following year. ${ }^{105}$ The treaty finally came into effect in February 2003.

While the Treaty of Nice succeeded in making some of the reforms that were its major focus, like Amsterdam these failed to achieve their intended scope. Negotiating member states fiercely guarded there own interests and special privileges, and Jörg Monar notes in his article "Continuing and Building on Amsterdam" that "emphasis at Nice was clearly on the protection of acquired interests against the effects of enlargement rather than a constructive preparation for enlargement." ${ }^{106}$ Much in the same way that the Nice summit was intended to resolve leftover issues from Amsterdam, many of the leftovers from Nice were intended to be included in the Draft Treaty of the Constitution, which is examined in the next chapter.

\footnotetext{
${ }^{103}$ Jörg Monar, "Continuing and Building on Amsterdam: The Reforms of the Treaty of Nice," in The European Union after the Treaty of Amsterdam, ed. Jorg Monar and Wolfgang Wessels, 321-344 (New York: Continuum, 2000), 321.

${ }^{104}$ McCormick, 74.

${ }^{105}$ McCormick, 75.

${ }^{106}$ Monar, 333.
} 
British and German Perspectives on European Integration

Before the British and German press coverage of the Amsterdam and Nice summits can be examined, it is necessary to discuss briefly the attitude that each country takes regarding European integration, both in general terms and at the times of the summits in question. Doing so will perhaps provide us with greater insight into the way that each country reports on the other during the integration process.

In general, it can be said that German political leaders have favoured European integration since its beginnings in the post-WWII era, when West Germany became a founding member of the European Coal and Steel Community that has evolved into the present European Union. Initially, this came from a desire to integrate Germany economically into Western Europe, so as to avoid the destruction caused by the expansionist wars of the previous half-century. With the reunification of Germany in 1990 , it continued to be the belief of all political forces that there was no alternative to the country's integration into the European system. ${ }^{107}$ Since the creation of the European Union in the early 1990s and throughout the summits of Amsterdam and Nice, German leaders have supported a model of Europe that aims for increased political integration to match the level of economic integration achieved thus far. Writing on the Treaty of Amsterdam, Helmut Kohl, the German chancellor and head of the German negotiating team during the summit itself, emphasized this desire for increased integration,

The Treaty of Amsterdam has shown that the unification of Europe is not to be held up or reversed, even by hesitant members... The common house of Europe is not finished yet; the basic structure is right, but further construction is needed.

\footnotetext{
${ }^{107}$ Rita Beuter, "Germany: Safeguarding the EMU and the Interests of the Länder," in The Amsterdam Treaty: National Preference Formation, Interstate Bargaining, and Outcome, ed. Finn Laursen, (Odense: Odense University Press, 2002), 94.
} 
The Treaty of Amsterdam opens the door- which is a decisive aspect for me- to the expansion of the European Union. ${ }^{108}$

Support for European integration among German citizens has generally matched that of their political leaders, although Rita Beuter has noted that, during the IGC and Amsterdam summit in 1996/97, support was relatively low, however, it rose again towards the end of 1997 . She suggests that this fall could be explained by the situation in Germany at the time, which was experiencing economic recession, relatively high unemployment, and a crisis related to outbreaks of Bovine Spongiform Encephalopathy (BSE, commonly called Mad Cow Disease), and further suggests that public debates on entry into the single currency could also have soured public opinion. ${ }^{109}$

On the opposite side of the Euro-coin is Britain, which has historically had an ambivalent relationship with Europe, and has been, according to Andrew Duff, an unreliable and often negative negotiating partner as well as "the single largest obstacle to reform of the EU."110 The British position on European integration has been summarized as follows,

Inherently and historically singular, the British relationship with the European Union is perceived as one which strives perpetually to occupy two positions at once: on the one hand, an inevitably very influential position in the shape and the 'beat' of the heart of Europe, sometimes even despite itself, and on the other, a position 'in orbit' of EU developments, painstakingly trying to maintain a 'safe distance'. ${ }^{11}$

\footnotetext{
${ }^{108}$ Helmut Kohl, "Foreword," in The European Union after the Treaty of Amsterdam, ed. Jorg Monar and Wolfgang Wessels, xi-xiii (New York: Continuum, 2000), xii-xiii.

${ }^{109}$ Beuter, 113-114.

${ }^{110}$ Andrew Duff, "Britain and Europe: The Different Relationship," in The European Union Beyond Amsterdam: New Concepts of European Integration, ed. Martin Westlake, 34-46 (New York: Routledge, 1998), 37-38.

${ }^{111}$ Clive Needle, "Foreword," in The European Union and Britain: Debating the Challenges Ahead, ed. Vassiliki Koutrakou and Lucie Emerson, (New York: St. Martin's Press, 2000), xvii.
} 
To varying degrees, the political leadership in Britain has displayed Eurosceptic tendencies, and this is especially true of the British Conservatives, who held power nearly unbroken for two decades from 1979 until Labour's election victory in May 1997, shortly before the Amsterdam summit. Among the British populace as well there is a lingering Euroscepticism, and it has been noted that most Britons do not identify with the European project. $^{112}$ Scholars such as Jeremy Rand have hypothesized various reasons for this, including Britain's historically peculiar relations with the continent, its special relationship with the United States, and misconceptions regarding British sovereignty and the perception of European integration as a zero-sum game. ${ }^{113}$

During the IGC preceding the Amsterdam summit, Britain's credibility as a European partner reached new lows as the Conservatives under John Major displayed an ambivalent and semi-hostile European policy, fighting against deepening political integration by stressing that "National Parliaments remain the primary focus of democratic legitimacy in the European Union," 114 and also opposing any form of further integration that did not also bring practical benefit. ${ }^{115}$ However, with the victory of Labour under the relatively youthful Tony Blair in May 1997, Britain was widely seen to reject the Euroscepticism, xenophobia and sleaze that were associated with the defeated Conservatives, and there came a renewed optimism regarding Britain's status as a negotiating partner in European affairs shortly before the Amsterdam summit. ${ }^{116}$ While

\footnotetext{
${ }^{112}$ Edward Best, “The United Kingdom: From Isolation Towards Influence?" in The Amsterdam Treaty: National Preference Formation, Interstate Bargaining, and Outcome, ed. Finn Laursen (Odense: Odense University Press, 2002), 376.

${ }^{113}$ Jeremy Rand, "British Identity and European Integration," in The European Union and Britain: Debating the Challenges Ahead, ed. Vassiliki Koutrakou and Lucie Emerson, 24-43 (New York: St. Martin's Press, 2000), 31.

${ }_{114}$ Best, 362.

${ }^{115}$ Best, 359-361.

${ }^{116}$ Sabine Lee, Victory in Europe? Britain and Germany since 1945 (New York: Longman, 2001), 225.
} 
scholars such as Andrew Duff and Edward Best have shown that the Labour leadership did in fact display much continuity with the previous government in terms of its goals concerning European integration, ${ }^{117}$ the rise of Labour nonetheless allowed Britain to take a more active and less reactive role in defining Europe, and further allowed for "reconciliation between the UK and its EU partners by allowing for achievements that would not have been possible under the previous government." ${ }^{118}$ Britain's active role in the EU continued through the summit at Nice, although over time it became increasingly obvious that the Europhile activities of British Labour were coming into conflict with a still-Eurosceptic British public. ${ }^{119}$

\section{Anglo-German Politics at the Time of the Summits}

The 1990s were a period of easing tensions in Anglo-German relations following a time of bilateral crises caused by the reunification of Germany and Margaret Thatcher's Euroscepticism and general dislike of Germans. ${ }^{120}$ In November of 1990, John Major replaced Thatcher as leader of the British Conservatives and began efforts to move Britain away from isolationism and towards more cordial relations with Europe, and particularly Germany. ${ }^{121}$ During this period, Major achieved a reasonable degree of friendship with the German Chancellor Helmut Kohl, who headed the conservative Christian Democratic Union (CDU), and who proved to be a staunch supporter of British aims during the negotiations on the Maastricht Treaty in the early 1990s. ${ }^{122}$ Despite a

\footnotetext{
${ }^{117}$ Duff, 45 and Best, 368.

${ }^{118}$ Best, 45.

${ }^{119}$ Claudia Crawford, "The Relations Between Great Britain and Unified Germany," KAS International Reports 9 (2010): 101.

${ }^{120}$ Lee, 219.

${ }^{121}$ Lee, 216.

${ }^{122}$ Lee, 217.
} 
more positive approach to European affairs than his predecessor, a position appreciated by the Germans, Britain under John Major still remained an awkward partner in the European integration project and especially in the IGC preceding the Amsterdam summit, as discussed in the previous section. The Anglo-German relationship also continued to be wracked by a series of minor crises, including the ejection of Britain from the Exchange Rate Mechanism in the early 90s and the BSE crisis in 1996.

Immediately preceding the conference in Amsterdam, in May 1997, John Major's Conservatives were defeated in a landslide victory for British Labour under Tony Blair, and, as mentioned previously, the promise of a more pro-European Britain was viewed favorably in many countries. At this time, prospects for more positive Anglo-German relations seemed likely, with the Blair government demonstrating more flexibility than its predecessor, for example, by allowing the incorporation of the EU Social Charter into the Treaty of Amsterdam, a document that Thatcherite Britain had rejected outright and John Major had prevented from inclusion in the Treaty of Maastricht. ${ }^{123}$ Relations improved again in 1998, when Helmut Kohl's CDU was replaced by the more left-leaning Social Democratic Party (SPD), and Gerhard Schröder became the new chancellor of Germany and quickly developed a close friendship with Tony Blair. In the following year, British Labour and the SPD published a joint paper entitled The Middle Way, which indicated that it was the intent of both parties to pursue rapprochement. ${ }^{124}$ Although Anglo-German relations would ultimately cool because of differing perspectives on the 2003 invasion of Iraq, ${ }^{125}$ at the time of the Nice summit and IGC, relations were cordial.

\footnotetext{
${ }^{123}$ McCormick, 199.

${ }^{124}$ Lee, 226.

${ }^{125}$ Crawford, 102.
} 


\section{Eye on Germany: British Press Coverage of the Amsterdam and Nice Summits}

Newspaper Coverage and Interpretation Overall

We may now turn to an examination and interpretation of the data provided by the British press during the time periods in question. This data comes from 104 newspaper articles that were taken from the months of May-June 1997, at the time surrounding and including the Amsterdam summit, and from 116 articles taken from December 2000 and June 2001, the months of the Nice summit and the subsequent treaty's rejection in the Irish referendum. At this point, it is important to note that the Daily Mail contained no relevant article for the time period surrounding the Amsterdam summit. Figures 2.1a and 2.1b show how the article coding compares overall.
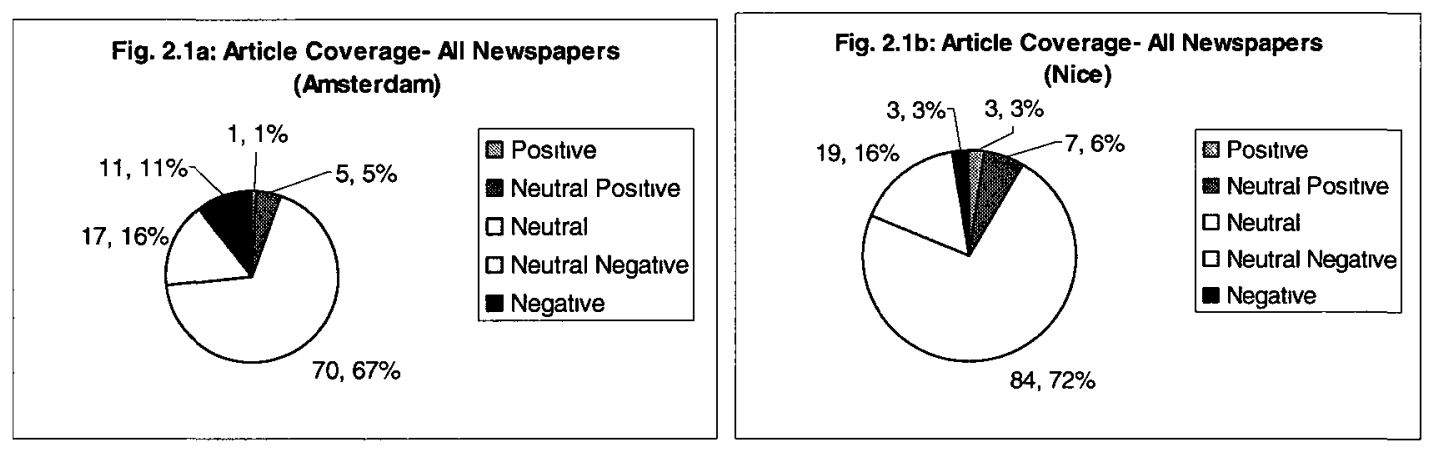

Immediately we can see that the coverage from both focal points concerning Germany was remarkably similar, both in terms of article quantity (104 to 116) and article coding. For most coding values, the proportional difference between each case was no more than $5 \%$, with the exception being in the purely negative articles, where there was a difference of $8 \%$ between Amsterdam and Nice, with Amsterdam being the more negative of the two. Combining neutral positive and pure positive articles, as well as neutral negative and pure negative in each case, we find that in relative terms the overall coverage of Amsterdam was more negative (27\% to $19 \%$ ) and the coverage of Nice was more 
positive ( $9 \%$ to $6 \%$ ), although this difference in positive articles was less pronounced.

Overall, we may thus state that:

British press coverage of Germany during the Amsterdam and Nice focal points was remarkably similar overall, with Amsterdam containing the higher percentage of purely negative coverage.

Comparison of these findings with those from the test case currently suggests that British press attitudes towards Germany within an EU context differ little from attitudes towards Germany expressed in other contexts, an interesting finding which runs counter to our hypothesis in the introduction. Recall Figure 1.1 from the previous chapter regarding German reunification:

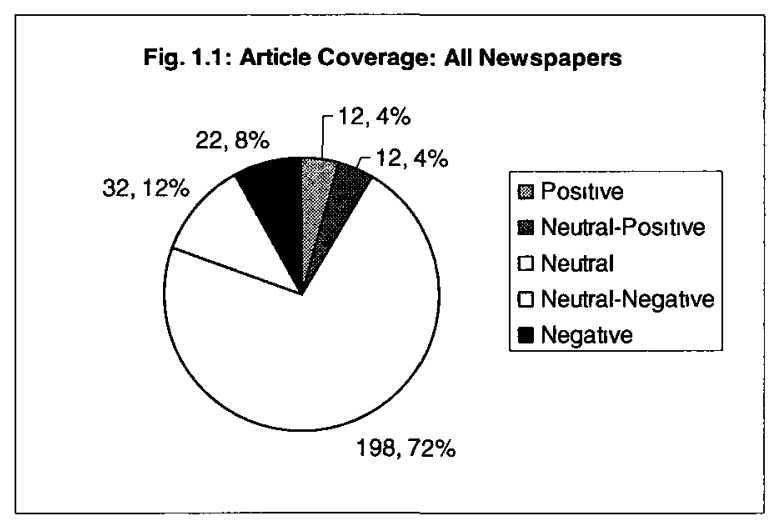

We can see that there were many more articles that concerned reunification than there were for the events of either Amsterdam or Nice, but that is to be expected because of the relative magnitude of the event. Besides the difference in quantity of articles, the data that this graph contains is not significantly different from that obtained from the Amsterdam and Nice focal points. In fact, this graph fits nicely between the graphs for Amsterdam and Nice in terms of proportional, overall negativity: when positive articles are combined with neutral-positive, and negative article with neutral negative in each graph, 
Amsterdam is more negative than Reunification, which is more negative than Nice.

Correspondingly and also rather oddly, the reverse is also true, with Nice being more positive than Reunification, which is more positive than Amsterdam. Given that the Amsterdam and Nice graphs were similar to begin with, this allows us to tentatively state that:

The amount of positivity and negativity in the British press concerning Germany is similar regardless of context.

Other general conclusions must be sought by moving on to article breakdown by newspaper:
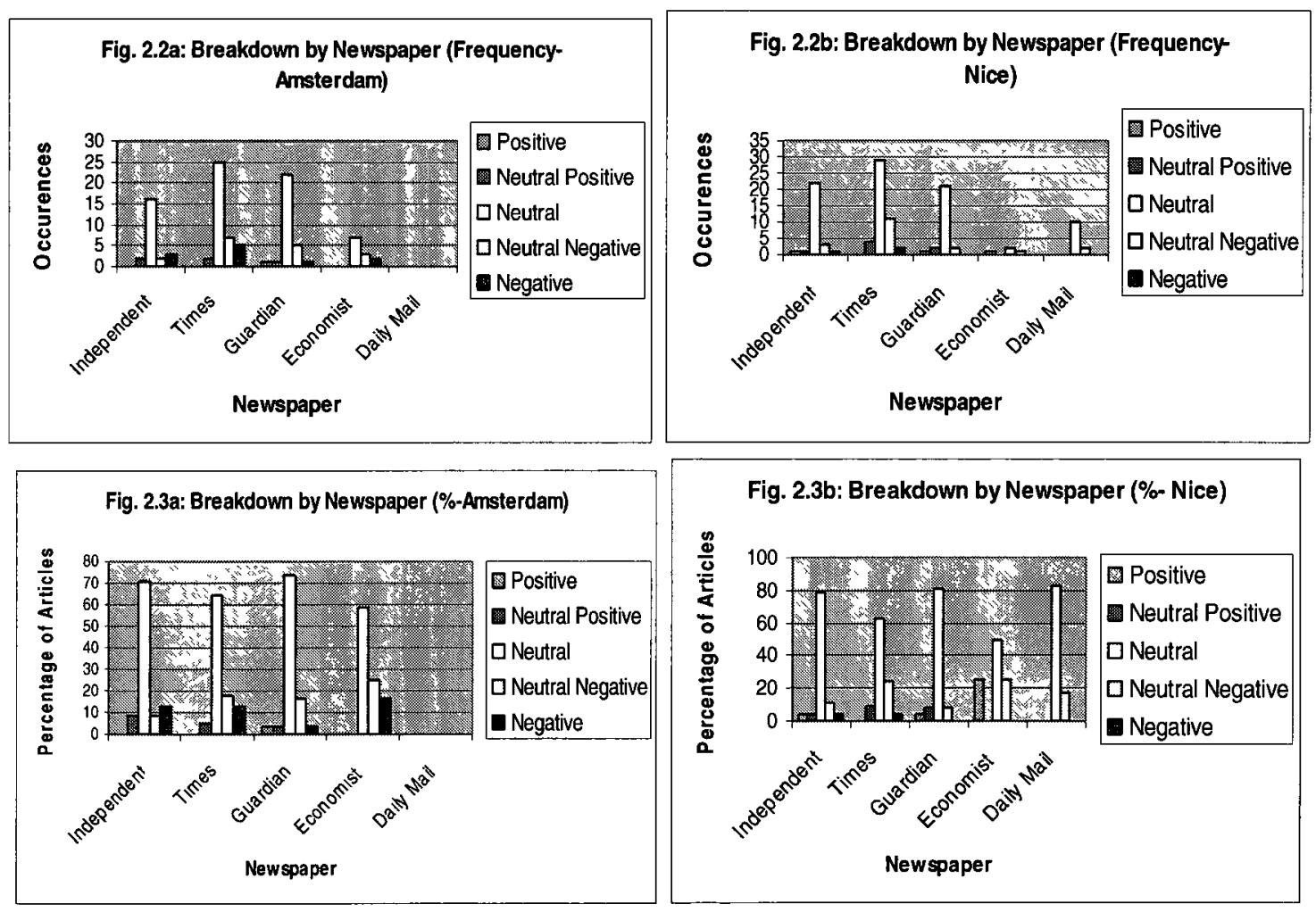

From this data, we can draw the following additional conclusions:

The attitudes that each of the three daily broadsheets (Independent, Times, Guardian) display towards Germany are generally consistent for both EU focal points. 
Examining Figures 2.3a and 2.3b, it can be seen that the percentage of articles assigned a given coding value are similar, and, in fact, that the relative negativity between the three remains the same. ${ }^{126}$ Regarding the first point, while the differences between the degrees of negativity or positivity (pure or neutral-pure) occasionally fluctuate significantly between the same newspaper for the focal points for Amsterdam and Nice, the ratios of Positive: Neutral: Negative remain similar. With regards to relative negativity, the total percentage of negative articles descends in both focal points from the Times (30.7\% and $28.2 \%$ for Amsterdam and Nice respectively) to the Independent (21.7\% and $14.3 \%$ ) to the Guardian (20\% and 7.7\%). The attitudes of the Economist and Daily Mail are more problematic to compare across both focal points, because of the relatively few articles of the former and lack of data for the latter.

Compared with the findings from the test case, there is once again no significant difference arising as a result of context. The attitudes of the three broadsheets are found to remain consistent across the three focal points, and their descending negativity relative to each other is also constant. Below, for the sake of comparison, is Figure $1.2 \mathrm{~b}$ from the previous chapter:

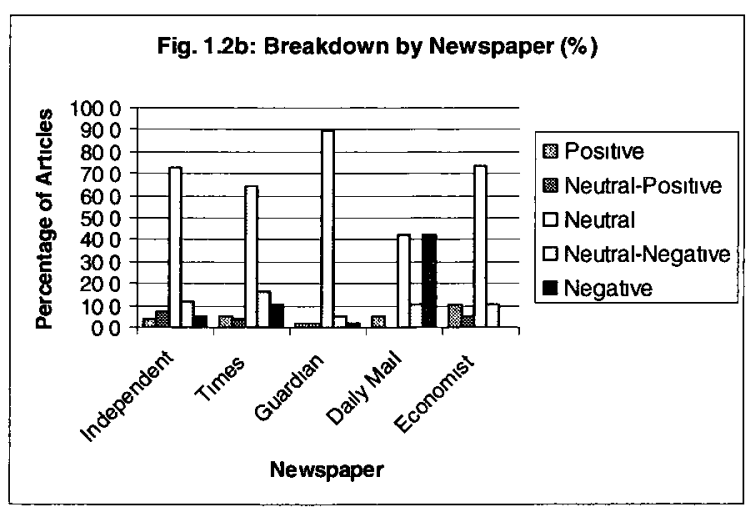

\footnotetext{
${ }^{126}$ Overall descending negativity for Amsterdam is Economist, Times, Independent, Guardian, (Daily Mailno articles), and for Nice is Times, Economist, Daily Mail, Independent, Guardian.
} 
The majority of press coverage by each newspaper during the time period for both Amsterdam and Nice was neutral.

As can be seen from Figures $2.2 \mathrm{a}$ and $2.2 \mathrm{~b}$, as well as $2.3 \mathrm{a}$ and $2.3 \mathrm{~b}$, the majority of articles concerning Germany that were written at the time of the Amsterdam and Nice summits were neutral in nature. In both cases, neutral articles made up at least $50 \%$ of the reports per individual newspaper, and in many cases this value was significantly higher. This is in line with previous findings and is to be expected, so it will not be dwelt on.

For both Amsterdam and Nice, when neutral articles are discounted, press coverage was generally negative.

Referring back to Figures 2.1a and 2.1b, it can be seen that when neutral articles are discounted, the combination of negative articles outweighs the combination of positive articles by more than 2:1 for Nice and more than 4:1 for Amsterdam. An examination of Figures $2.3 \mathrm{a}$ and $2.3 \mathrm{~b}$ shows this to generally be the case for most individual newspapers as well, with exceptions being in the coverage of the Guardian and Economist during the time period for Nice. Once again, this is in line with the findings from the test case, and in line with our hypothesis concerning the general negativity of the British press.

For both focal points, the negativity was not necessarily blatant.

We can see from Figures 2.2a and 2.2b that, with the exception of the Independent during the Amsterdam summit, all newspapers contained more neutral-negative articles than negative, meaning that negativity was more likely to be subdued rather than blatant. Referring back to the test case, this was also found to be true. This allows us to qualify 
existing notions of negativity in the British press by stating that, regardless of context, negativity regarding Germany tends to be subdued rather than blatant.

Ultimately, all of these findings tell us that there is an overall tendency within the British press to report on Germany in a consistent and (when neutral articles are discounted), generally negative manner when discussing the European integration process. However, as has been indicated, this was also found to be the result in the test case, and as of this point we are unable to say with certainty that coverage of Germany with regards to European integration is any different than coverage of Germany in general. The final decision on this point must wait until the data from the following chapter concerning the EU constitution is considered.

\section{Individual Trends and Themes}

To assist in our examination of (German) image construction in the British press during the European integration process, all relevant articles run by all individual newspapers during the Amsterdam and Nice focal points were examined, and a list of commonly emphasized themes (or stereotypes) ranging from broad to specific was created. There were seven such themes discovered in coverage of the Amsterdam summit, and most of these were found to recur during coverage of the Nice summit (and Irish rejection), which added one additional theme that was not generally present during the Amsterdam coverage. With some exceptions, these themes generally did not correspond to a given positive, neutral, or negative coding value; this was determined instead by the manner in which a given newspaper reported on them. Additionally, the number of occurrences of these themes did not necessarily bear any relation to the 
number of articles being examined, as some articles contained multiple themes, while others contained none. The common emphases regarding Germany were found to be:

1) References to the "Franco-German axis," motor, or mentions of France and Germany as a pair, or within the same sentence.

2) The use of militaristic language when discussing Germany, portraying Germany as a bully, or referencing the Nazis of Second World War.

3) The characterization of Germany as ambitious, overly ambitious, or "federalist" in the context of the EU.

4) Germany as an opponent of Britain or British desires (usually EU-related).

5) Germany as an ally or friend of Britain, or sharing British desires (usually EUrelated).

6) Positive references to the German economy, or "sound" German money.

7) Negative references to the German economy.

The theme present during the Nice focal point that was not generally present during in the Amsterdam coverage was:

8) References to German power or dominance, by itself or in conjunction with other states.

The frequency with which a particular newspaper used a given theme, whether or not it recurred between focal points, and in what light it was presented allows us to gauge the concerns of a newspaper with regards to Germany and the manner by which its image was constructed both within, and outside of, the European integration context. 
Recalling that for the test case, the Daily Mail was the most unambiguously negative newspaper in its attitudes towards Germany, it is somewhat surprising to note that, while the newspaper ran no articles relevant to this project during the Amsterdam summit, thereby limiting our ability to compare attitudes towards Germany within the integration project, the findings for Nice are nonetheless striking. In the test case, purely negative articles equaled the number of neutral ( 8 each), with neutral and neutralnegative articles found to focus on the security of Europe in light of German reunification, and negative articles generally referencing the threat of growing German power and making direct linkages to Second World War and the Nazis. Although the number of relevant articles run for the test case and the Nice focal point was reasonably similar (19 and 12 respectively), for the Nice case the Daily Mail scored the highest neutrality percentage of all newspapers, with 10 article or $83.3 \%$, where previously it scored the lowest (42.1\%). The remaining two articles (16.7\%) were neutral negative, and there was a noticeable lack of purely negative articles.

Figure 2.4 shows the relatively neutral trend line for the December summit in Nice. No trend has been included for the Irish rejection in June 2001, as only two relevant articles were run during this time period (on the $10^{\text {th }}$ and $21^{\text {st }}$ ), both of which were neutral.

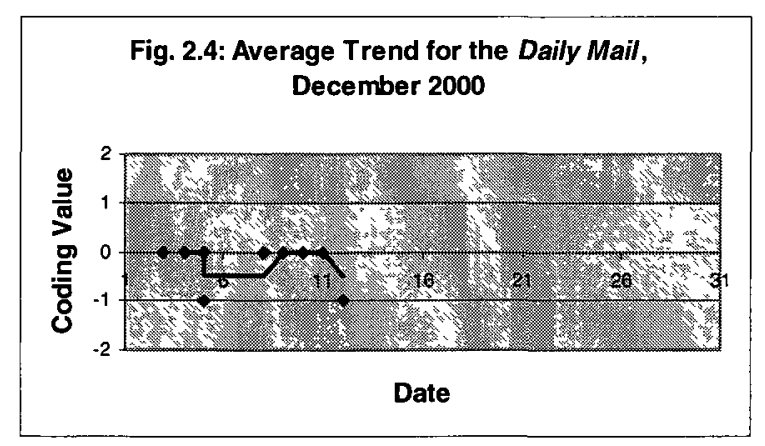


In terms of the themes mentioned above, the Daily Mail scored as follows:

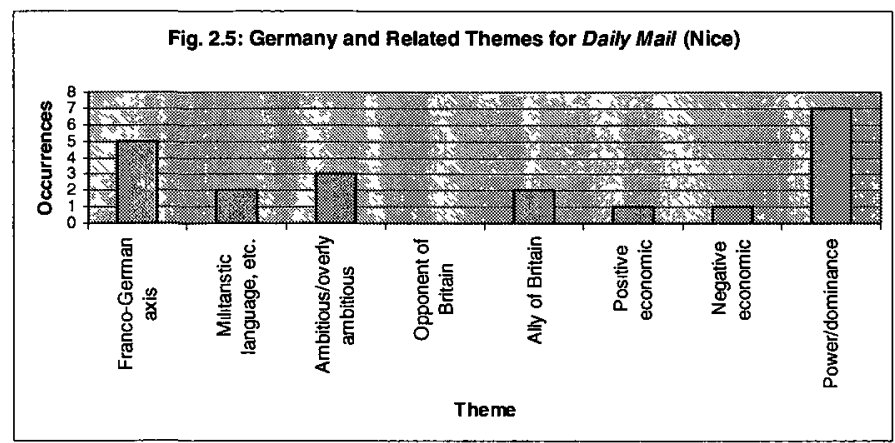

We can see that two of the principle focuses of the Daily Mail concerned German power and dominance, similar to the findings in the test case, and the Franco-German partnership. However, German power and dominance was not treated in the same negative and apprehensive way that it was in the test case, rather it revolved around the reweighting of votes in the Council of Ministers (a principle concern of Nice) to reflect the increase in German population as a result of reunification. Referring back to the discussion of article coding mentioned above, the neutral articles generally covered the summit happenings, and both neutral-negatives were similar in that they contained apprehension about the actions of France and Germany, not German power. The first neutral-negative article mentioned a Franco-German fight, stating, "the signs are the summit could be the stormiest yet, with France and Germany also locked in a row over their relative voting strengths." ${ }^{127}$ The second such article contained a report on fears about France and Germany and the speed of integration:

And the insistence of states on defending their national interests raised fears that as the EU is enlarged, a two-tier Europe is inevitable with a core of integrationist states led by France and Germany going forward faster than the rest. ${ }^{128}$

127 "Prodi veto attack fails to sway Blair," Daily Mail, December 5, 2000.

128 "Hague says Blair has sold us short at summit," Daily Mail, December 12, 2000. 
Overall, these findings indicate that the Daily Mail had shifted away from its concerns regarding a reunified Germany threatening the security of the continent in concrete and militaristic terms, to instead viewing Germany in conjunction with France as being a vaguely sinister force within the framework of the European project. It should be noted, however, that while the image of Germany has changed, it remains a semi-sinister entity. It was hypothesized in the previous chapter that the Daily Mail might be more willing to view Germany favorably (or less negatively) if it were integrated into Europe, and current findings seem to suggest that this was the case. That the Daily Mail continued to be wary of Germany within this context can perhaps be attributed to the newspaper's generally Eurosceptic nature, although we must compare these findings to those contained in the next chapter to see if these assertions are borne out.

It has already been shown that the Times remained relatively consistent in its treatment of Germany in both the Amsterdam and Nice focal points as well as in the test case. Figure 2.6 shows this correlation:

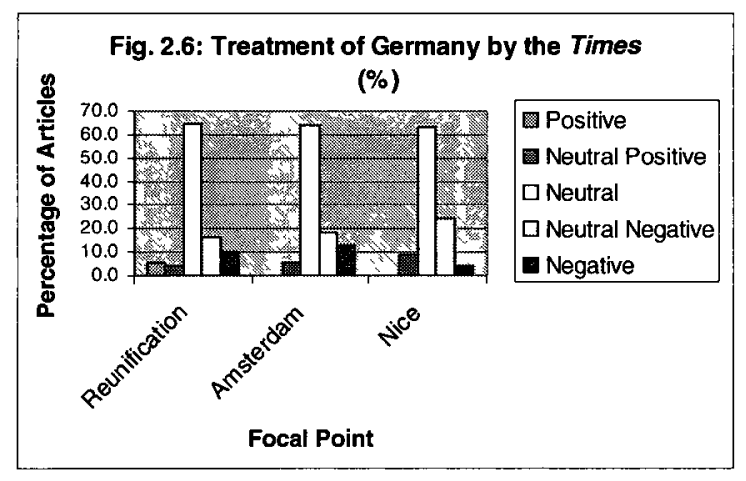

The only real difference seen here is that there were no pure positive articles run during either focal point relating to European integration, which we can hypothesize to reflect the Times' Eurosceptic nature and its feelings towards Germany in the process.

Discounting neutrals, reporting on Germany remained generally negative, with neutral- 
positive and pure positive articles always being outnumbered by neutral-negative and pure negative articles respectively. Neutral-negative articles, generally containing second-hand reports, remained the preferred method of negative reporting on Germany.

Figures 2.7a and 2.7b show the trends for Times reporting during the Amsterdam summit. Note the generally negative trend that becomes even more marked surrounding the conference (16-18 June). Figures $2.8 \mathrm{a}$ and $2.8 \mathrm{~b}$ show the trends for the Nice summit and the Irish rejection. The trend is more sporadic for the time period surrounding the Nice summit, but is still clearly more negative than positive. Times coverage of Germany during the Irish rejection remains generally negative.
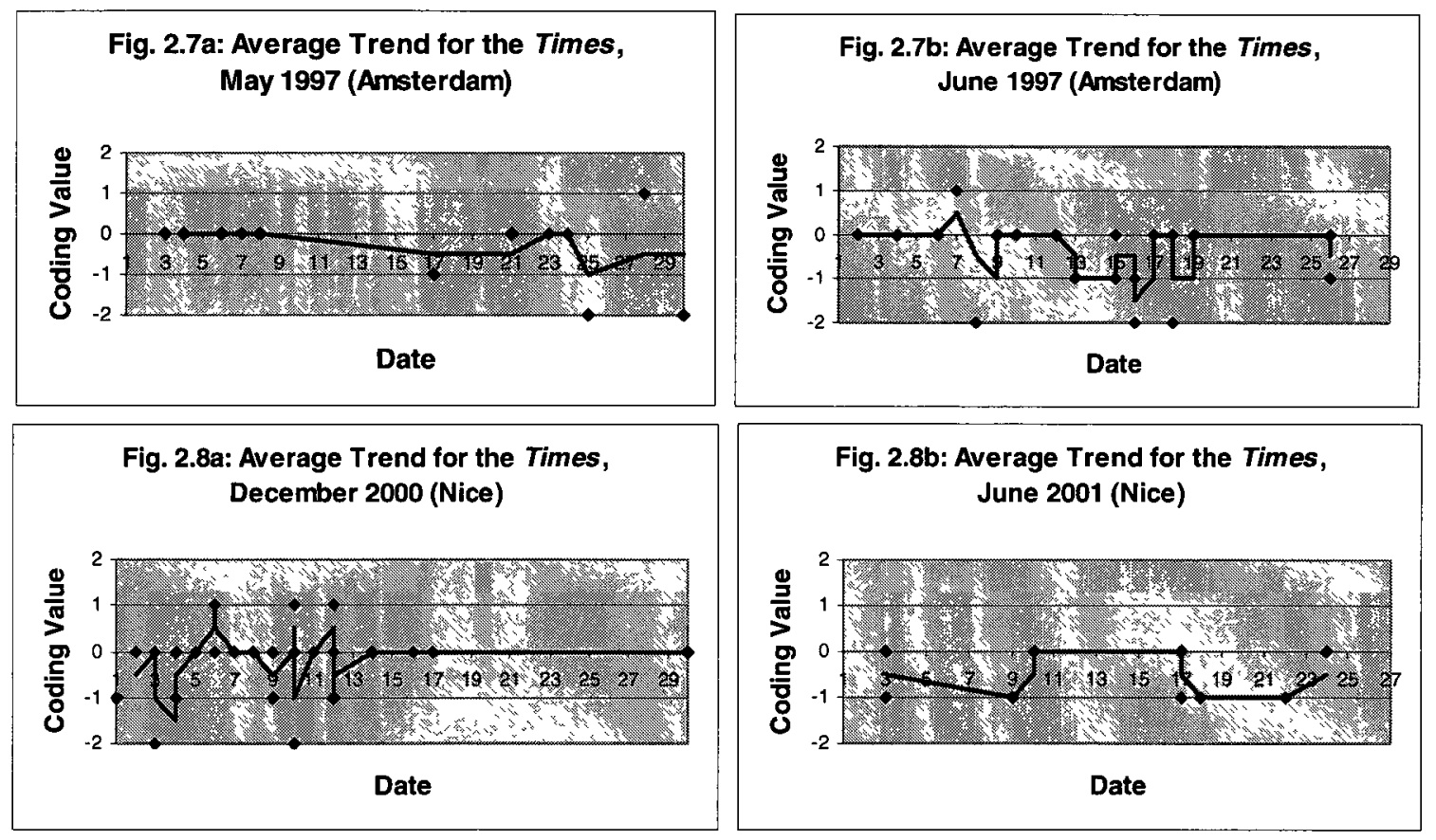

These findings all suggest an inclination in the Times to view Germany negatively both within and outside the context of European integration, but there are indications at this point that coverage in the latter case is more inclined to be negative, in that there is a relative lack of pure positive articles, and this reinforces our hypothesis that a 
newspaper's position on integration will affect its coverage of a given country within the process.

Recalling that, in the test case, the primary concern of the Times revolved around Germany and the security of Europe, specifically relating to German neutrality and its relationship with NATO, and that negative articles generally referred to this as well as the Nazi period and occasionally economic concerns, it can now be asked if and how these emphases changed when discussing European integration. Referring to the themes mentioned above, the Times scored as follows for Amsterdam and Nice:
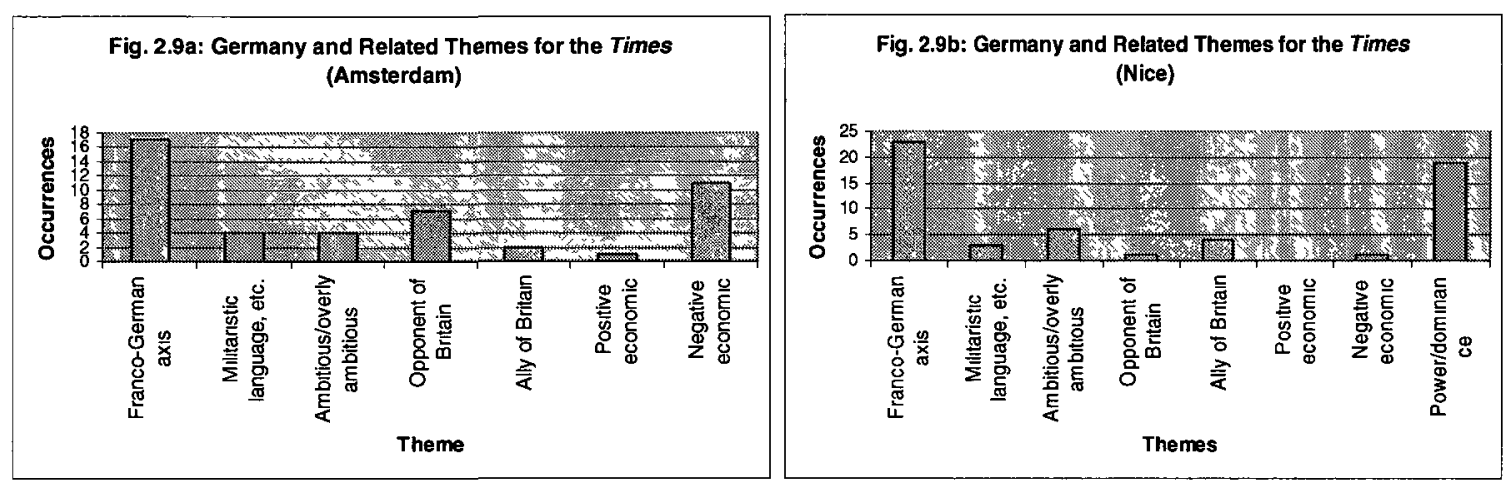

From these graphs, it becomes clear that the Times assigned much importance to the Franco-German relationship in both cases, but beyond this, there is little correlation between other themes. Negative economic conditions were the secondary concern at Amsterdam, while they almost disappeared at Nice and were instead replaced by themes of German power or dominance, similar to the reporting of the Daily Mail.

Turning to an examination of individual articles, we find for Amsterdam that most of the neutral articles simply discussed events that were related to the Amsterdam agenda and the progress being made in such areas. Two neutral positive articles existed but were not linked by a common theme; one reported on Germany's ability to create jobs as being 
superior to Britain's, ${ }^{129}$ and the other discussed a warming of relations between the two countries. ${ }^{130}$ Neutral negative articles almost always focused on the Franco-German relationship, portraying it in a similarly sinister manner as the Daily Mail, and often suggesting that it would press on with future integration despite the desires of other nations (like Britain):

France and Germany are pressing for the EU to take over the Western European Union, the European wing of Nato, but the scheme is likely to be diluted in the face of opposition from Britain and neutral states...The [Blair] Government is more sceptical than John Major's team about setting up a system that would let states club together with new joint policies, leaving out unwilling members. ${ }^{131}$

Tony Blair faces an ambush at the summit by France and Germany over plans to create a two-speed Europe which could scupper his drive to win a seat for Britain at the EU's top table. ${ }^{132}$

These articles also tended to focus on economic problems more often than not:

"France and Germany may be in bed together but they are having very different nightmares," said Dominique Moisi of the French Institute for International Relations. "Germany's are about inflation. France's are about unemployment." 133

Articles that were coded as purely negative tended to be more diverse, but these also tended to include an economic aspect, thus retaining some continuity with the findings from the test case:

Forced into a humiliating climb-down over his ill-conceived plans to revalue the country's gold reserves, the right-of-centre German leader sees little hope of rescue. Unemployment, which at $4.4 \mathrm{~m}$ has become the chief of Kohl's woes, soared by another 56,000 to a new record last week... [The French government]looks set to serve notice at today's meeting in Luxembourg of its plans to unpick the Stability Pact, a German-inspired economic straitjacket which will bind those countries who sign up for monetary union to tough limits on government borrowing. ${ }^{134}$

\footnotetext{
129 "Open a new chapter for the workers of Europe- Opinion," Times, May 28, 1997.

130 "Blair tells Kohl- Our borders must stay," Times, June 7, 1997.

131 "Tough bartering begins on 'son of Maastricht' pact," Times, May 17, 1997.

132 "EU ministers seek job deal to save euro." Sunday Times, June 15, 1997.

133 "Franco-German marriage feels the strain of menage-a-trois," Sunday Times, June 15, 1997.

134 "Kohl and Chirac bow to new socialist order across Europe," Sunday Times, June 8, 1997.
} 
Like with the Daily Mail, these findings show that the Times has now become less inclined to portray Germany as a force which could threaten the European order militarily, and more of a semi-sinister opponent that might drive European integration beyond those limits desired by Britain, and whose economic decisions were at odds with those of the newspaper itself. Both of these things are likely to be explained by the Eurosceptic position of the newspaper, and its liberal position on finance and economics.

Turning to individual articles from the Nice summit and Irish rejection, we find that there is some continuity and some rupture with the findings for Amsterdam. Like Amsterdam, most of the neutral articles tended to deal with the agenda for Nice, specifically vote reweighting and its consequences for Germany. There was also a continued interest of the Times in the Franco-German relationship. In terms of differences, however, all four of the neutral-positive articles from the Nice summit contained the common theme of Germany as an ally of Britain, at least in the context of EU negotiations, where previously there was no real link between these types of articles.

As can be seen from Figure $2.9 \mathrm{~b}$, there was also a preoccupation with German power and dominance, similar to those findings from the test case, but different from those findings from Amsterdam. This theme was scattered throughout articles assigned various coding values, but was generally portrayed negatively at the time of the summit itself and was often found through second-hand reporting in articles coded as neutral negative. The Franco-German relationship was also mentioned in many articles coded as neutral-negative, but generally this was in more neutral terms, and often discussed a disagreement between the two countries in terms of voting weights, with some articles giving the impression that this special relationship was falling apart. More often than not, 
the focus was on the reassertion of German power, although occasionally France was included in this equation:

A Jospin minister this month openly accused M Chirac of complicating the hard grind of treaty negotiation by painting grand visions of a Union dominated by France and Germany. ${ }^{135}$

In Italy, the mood was especially bleak. La Republica suggested that the summit had been hijacked by what amounted to a German plot to reassert its dominance in Europe. ${ }^{136}$

GERMANY emerged yesterday as the main victor in the marathon battle of Nice, winning more power and most of its other objectives in a new EU treaty that was widely decried in Europe as a disappointing minimum... The Greeks left the summit grumbling about a new German-led "directorate" at the European helm. ${ }^{137}$

This theme of German power was also present in one of the two pure negative articles, one of which discussed the privileges of the "big four," (Britain, France, Germany and Italy), and stated that "Germany wants to become the "big one" instead." 138 The remaining negative article was an editorial that complained about the possible future of integration and contained numerous negative stereotypes about the Germans, although this was generally not typical of Times reporting during the Nice summit.

It should be noted at this point that all articles run by the Times during the period of the Irish rejection were either neutral or neutral-negative in nature, with the neutralnegative articles containing more diverse themes than the threat of German power found in those articles surrounding the Nice summit. Of the five articles from this time period, one did indeed reference German (and French) power, commenting on Irish fears that "larger countries such as France and Germany are gaining power at the expense of the

\footnotetext{
135 "Scandal erodes Chirac's influence as EU negotiator- The Nice Summit," Times, December 4, 2000.

136 "Europe's press blames 'fiasco' on Chirac- Nice Summit," Times, December 12, 2000.

137 "Germany triumphs on the EU battlefield- Nice Summit," Times, December 12, 2000.

138 "Europe's leaders prepare to fight for future of EU dream- EU summit at Nice," Sunday Times, December 3, 2000.
} 
smaller countries." 139 The remaining neutral-negative articles dealt with economic problems, the undemocratic nature of German decisions on the Euro, and several also returned to the theme of France and Germany forming a vaguely sinister and overly ambitious core of Europe. This was generally absent during the Nice summit while the two countries were in a state of disagreement, but otherwise this seems to be a common representation in the Times.

Overall, these findings show us that the Times has generally reported negatively on Germany both within and outside of the European integration project. We have seen that economics is a theme that is discussed in all focal points, and that Germany is frequently portrayed as a powerful and menacing entity, whether by itself outside an EU context, or paired with France within one, similar to Germany's treatment in the Daily Mail. Some themes do tend to shift based on their relevance at the moment; for example, the German economy was suffering at the time of the Amsterdam summit and thus economics was emphasized, while considerations at Nice concerned the reweighting of votes, and thus German power and dominance was the key theme.

Like the Times, the Independent has previously been shown to remain consistent in its reporting on Germany between the Amsterdam and Nice focal points as well as the test case.

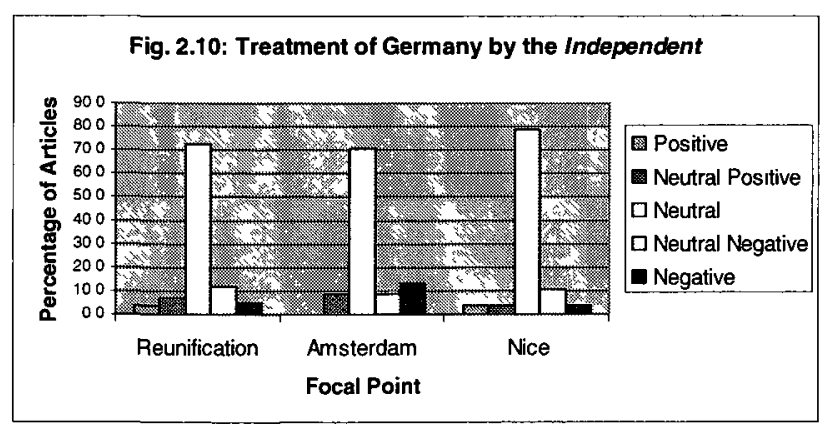

139 "Fear fuels rebels' campaign," Times, June 9, 2001. 
It is evident that there is some degree of discrepancy between reporting for Amsterdam and the other two focal points, notably in the higher count for purely negative articles and in the lack of pure positives at Amsterdam. Other than this, negative articles always outweigh positive, although compared with the same graph from the Times, the number of both neutral-negative and pure negative articles is much lower. We can thus say that, like the Times, the Independent is generally negatively disposed towards Germany regardless of the focal point, but unlike the Times, there is little indication that reports concerning European integration are any more negative or positive than otherwise. Below are the trend lines for both the Amsterdam and Nice focal points. There is no trend for the June 2001 Irish rejection, as only two relevant articles were run during this period, both of which were neutral. We can see that the trend for May 1997 is generally neutral, dropping to negative in the lead-up to the Amsterdam summit, and then becoming more positive during the summit itself. The trend for the Nice summit is more erratic and the heavier concentration of articles makes it harder to interpret.
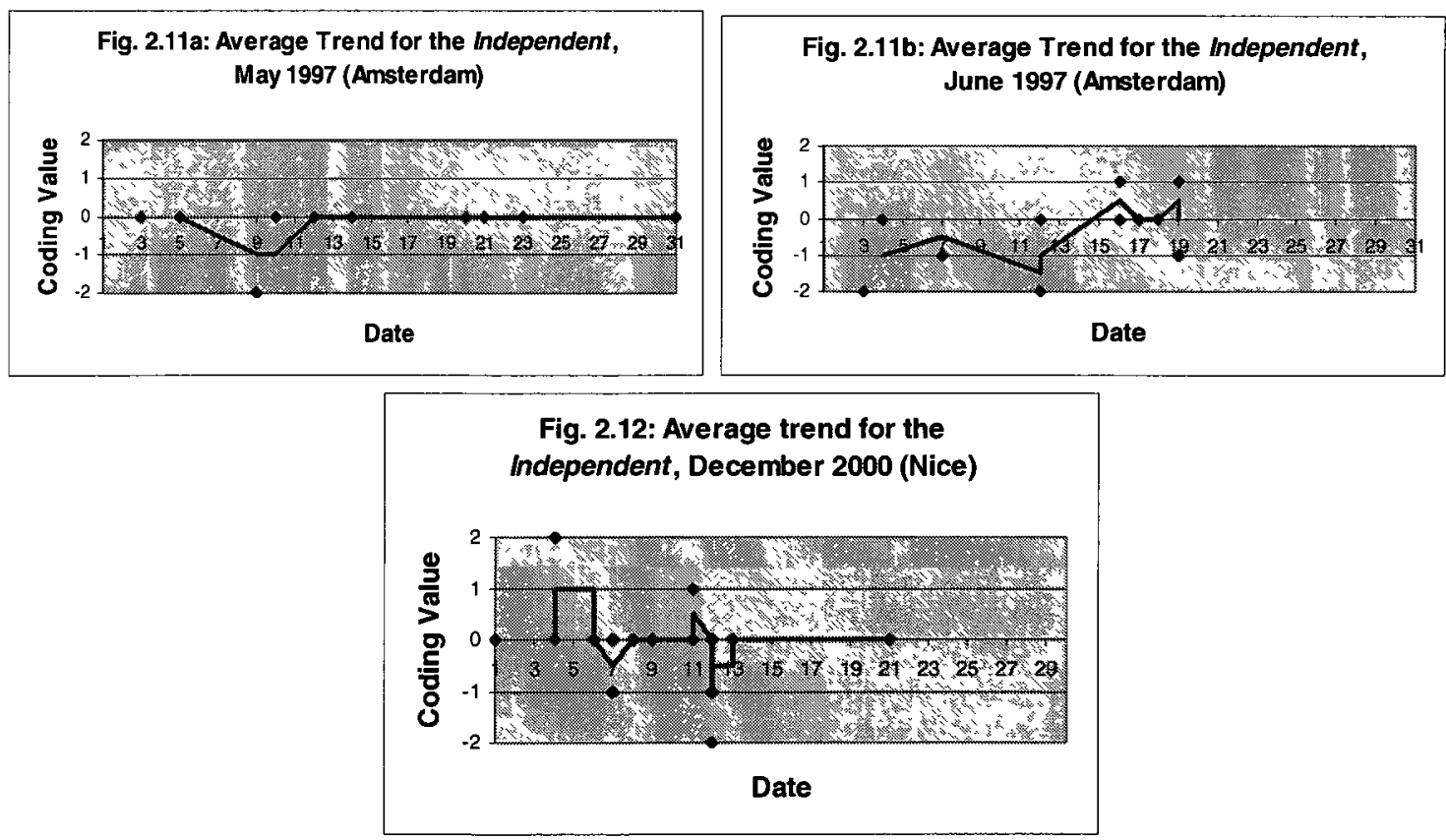
Referring back to the findings from the test case, we found that neutral articles in the Independent discussed a wide range of topics; neutral-negatives tended to discuss the problems of the speed of German reunification while negatives dealt with security issues and the threat of German militarism. Positive articles spoke well of Germany in an EU context, although we can currently say that from within an EU context, non-neutral Independent reporting tends to be predominantly negative. How this is manifested, and what other themes emerge, will be examined now.

Referring to Figures 2.13a and 2.13b, and recalling our findings for the Times, we see that there is a remarkable correlation between the themes present in both newspapers for both summits.
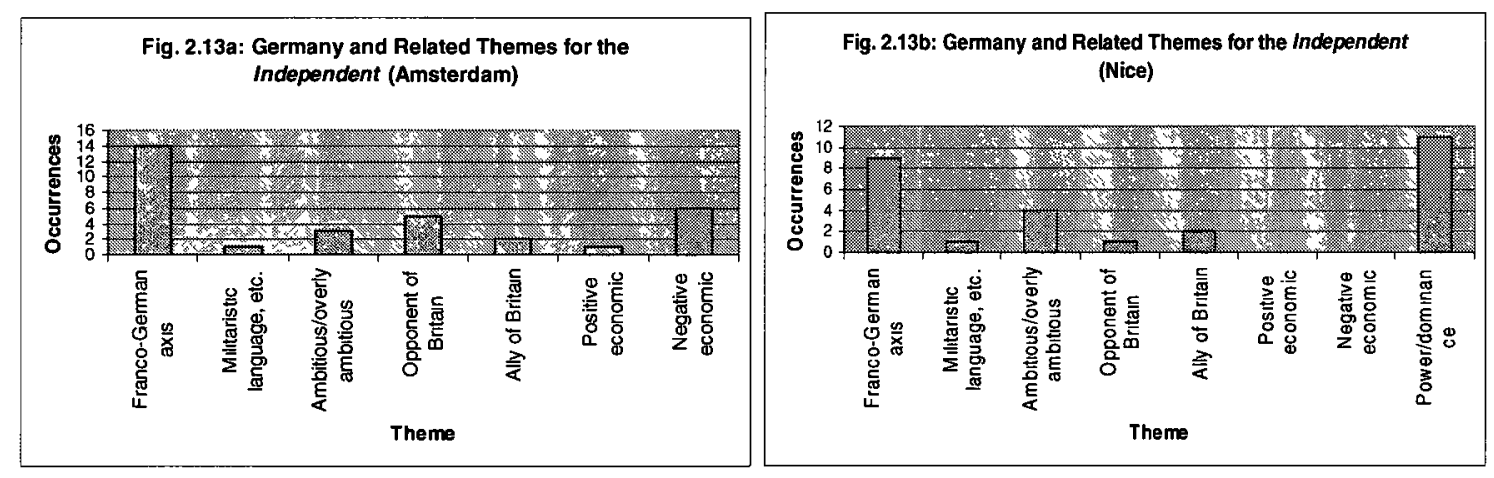

On an individual article basis, during the Amsterdam summit most neutral articles focused on finances, summit happenings, or discussions of the EU defence plan and its relationship to NATO. In these articles, France and Germany were almost always paired and generally advocating something with which Britain disagreed. Only two neutralpositive articles existed, which were balanced by two neutral-negatives, neither of which shared common themes. One neutral positive article approved of German financial measures, saying "there may be times in the future when it will make perfect sense for 
Europe to think similarly to the way that Germany is thinking today," ${ }^{140}$ and the other noted that, thanks to German actions, the British had had to give up less in the negotiations than they had initially intended. The neutral-negative articles respectively reported on the state of the German economy, and the "extravagantly integrationist hopes of the Germans and the Benelux countries just a few months ago."

In terms of the three negative articles from Amsterdam, two of these shared a common theme of negative economic behavior on the part of the Germans, both referring to dubious actions related to the single currency (similar to the coverage in the Times), while the last viewed the Franco-German axis as something of a bully:

Handling the British problem is only one of Mr Kok's concerns as he drives the EU presidency towards Amsterdam. He must also keep an eye on the FrancoGerman engine and ensure that the rights of smaller member states are not trampled on. ${ }^{142}$

Turning to the time period of the Nice summit, we find that, in terms of negative coverage, economic considerations have been replaced by a focus on German power, however, unlike the coverage in the Times, what the Independent viewed negatively here was not German power on its own, but the fact that Nice had reinforced the superiority of the big powers, of which Germany was a member, over the small. This was the main focus of the articles coded as negative and neutral negative, and within the article coded as negative, the theme of the German bully appeared again, as it did at Amsterdam, although Britain was also portrayed in a negative light here,

An 11th-hour rebellion led by Belgium, was put down by brute force as Britain Germany, France and Italy embedded their dominance of European decisionmaking while enhancing the power and influence of the next biggest nation, Spain...At one point, officials said, Tony Blair, the Prime Minister, and Gerhard

\footnotetext{
140 "French demands would not mean a weaker euro," Independent, June 16, 1997.

141 "Nevermind the Nerd, vote for Old Rustbucket," Independent, June 19, 1997.

142 “Kok serves Blair his hot potatoes," Independent, May 9, 1997.
} 
Schroder, the German Chancellor, confronted and bullied their Belgian and Portugeuse counterparts in a display of raw power politics. ${ }^{143}$

Coverage of Nice also contained one pure positive and one neutral positive article. The former commended the Franco-German "ideal of peace"" that lay at the heart of European integration, and the latter reported on cooperation between Britain and Germany in the negotiations. As one final point, it is interesting to note that within coverage of Nice, France and Germany were rarely paired as they were in coverage of Amsterdam (though this was possibly due to the Franco-German dispute over voting weights).

Overall, the findings here allow us to say that, while the Independent remains negative in its coverage of Germany in general, in the context of European integration, there is some shift in themes. The newspaper has dropped its concerns with security, but like the other newspapers examined so far, the Independent still portrays Germany as a somewhat threatening and powerful force through references to power politics and bullying. Like the Times, it also seems that emphasis for the Independent is to a certain extent based on an issue's relevance at the moment, with economics dominating the Amsterdam focal point, and German power that of Nice.

By way of differences with individual newspapers, it is interesting to note that the Franco-German partnership in general was not treated the same way as in either the Daily Mail or the Times. As we have seen, both of these newspapers are Eurosceptic publications and tended to portray France and Germany as vaguely sinister forces pushing integration along faster than they should and possibly leaving unwilling

143 "Nice Summit- The Deal- Big Four emerge triumphant after diplomatic 'coup'," Independent, December 12, 2000.

144 "A historic week for Europe- but it does not feel like it," Independent, December 4, 2000. 
members behind. In the Independent, criticism of these two arose more from concern of them damaging, stalling or otherwise acting less European than they should in the European project. This is very likely because of the Independent's relatively proEuropean stance, and this lets us hypothesize that the newspaper would report more positively on Germany in situations where it acted in a more EU-friendly way. If this is the case, findings from the next chapter may shed further light on this.

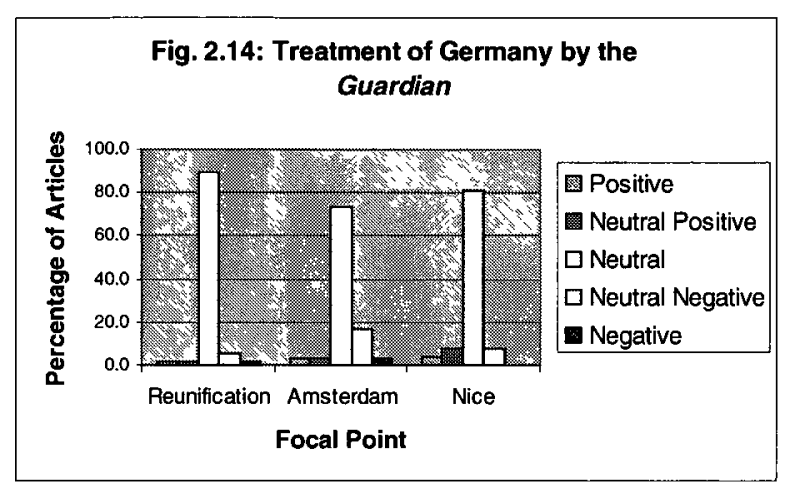

The Guardian perhaps shows the most discrepancy between focal points of the three broadsheet publications. It is clear from Figure 2.14 that coverage of German reunification was heavily neutral, and this degree of neutrality is not matched by either of the summits. It is also clear that the Nice focal point contains more positive articles than negative, which contrasts with the findings for Amsterdam.
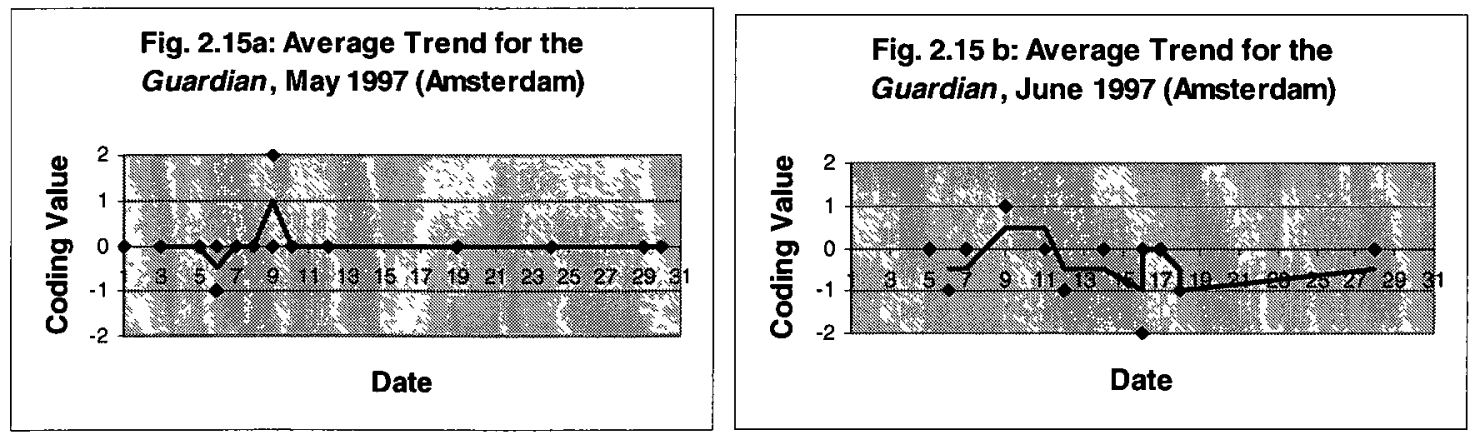

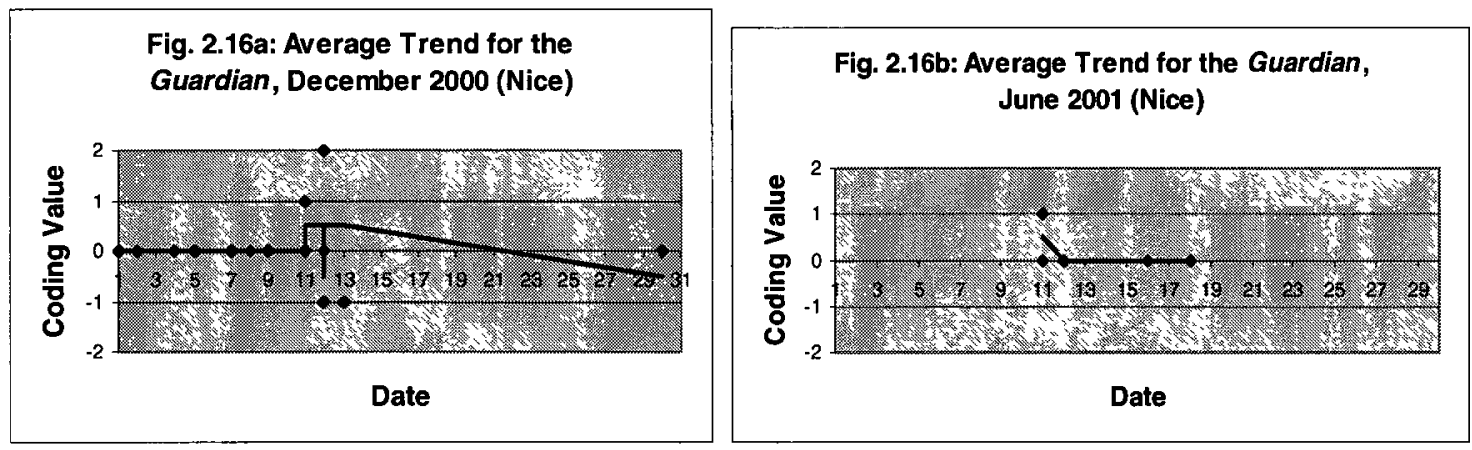

The above trends for the Guardian tell us little, besides the fact that coverage of Germany tended to be negative surrounding the Amsterdam summit and positive at the time of Nice. In terms of the general themes connected to Germany during discussions of the European integration project, Guardian coverage surrounding the Amsterdam and Nice focal points was as follows:
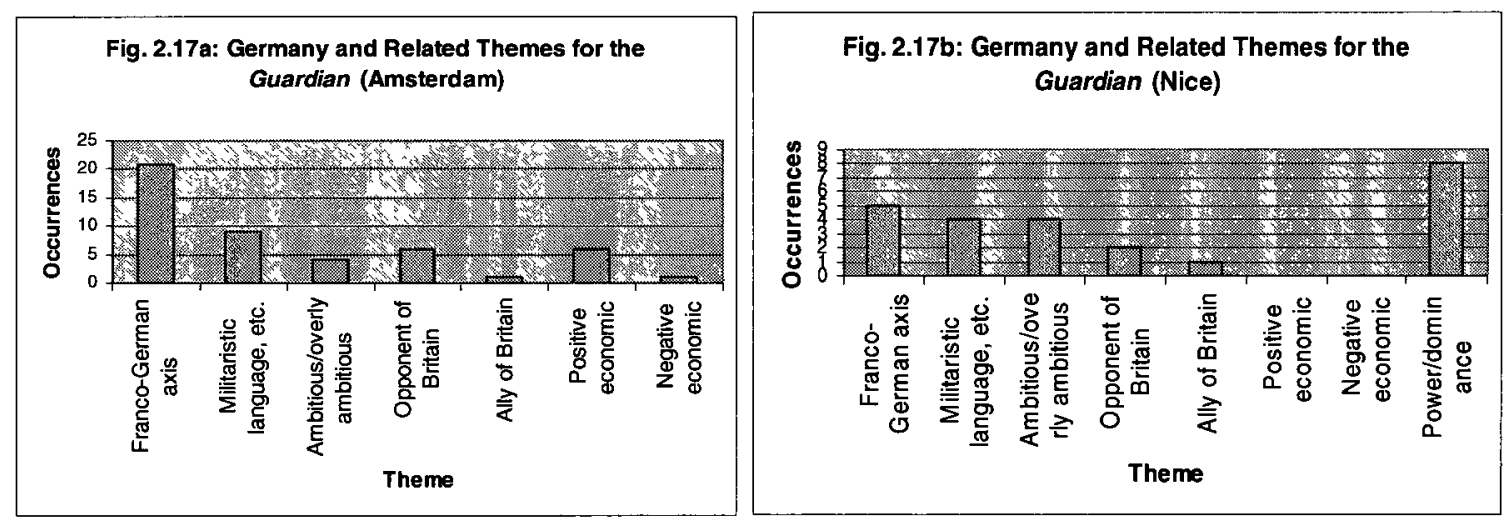

While focus on the Franco-German relationship remains high in both focal points, and German power is featured at Nice, as has been the case with previous individual newspapers, it is interesting to note that, unlike the Times and Independent, the Guardian contains few negative economic references for Amsterdam, rather having a reasonable quantity of positive or "sound money" references instead.

Neutral articles from the Amsterdam summit time period generally concerned summit happenings, but also placed a significant focus on the a Franco-German defence 
proposal, as well as the power of the Franco-German axis in general, which was taken to be the dominant force in the EU. Neutral-negative articles also focused on the FrancoGerman relationship, hinting that it either had too much power, or that it was in the best interests of Britain to oppose its desires:

TONY BLAIR arrives in Bonn today for critical talks with Chancellor Helmut Kohl, seizing the opportunity of converging British and German interests to undermine the Franco-German axis which has dominated the European Union...The Franco-German alliance remains the core of Mr Kohl's European project. It is an axis which, as a rule, weathers political storms regardless of who is in power on either side of the Rhine. ${ }^{145}$

On the other hand, the Guardian also noted in its only neutral-positive article that some ideas of France and Germany were "sensible enough." ${ }^{146}$ Generally, however, the actions of the Franco-German axis attracted more scorn than praise. Of the two articles coded as purely negative from the Amsterdam focal point, one picked up this theme as well (the other commented on Germany's economic performance, as similar to other newspapers), suggesting that the relationship had a stubborn and destructive single-mindedness:

The summit will conclude with [the leaders of France and Germany] insisting that...it is still full speed ahead for a single currency...This is typical of the arrogant way in which Europe's political class has ploughed on with monetary union, despite a mountain of evidence that it is bureaucratic, riddled with design flaws, and rides roughshod over Europe's economic, geographic, linguistic and cultural diversity. ${ }^{147}$

It is surprising to note, for this focal point at least, that the Guardian, despite being a pro-

European newspaper, treated the partnership of France and Germany more like the

Eurosceptic Daily Mail and Times. Finally, the one article coded as positive from the

Amsterdam focal point came from a month before the summit itself and was merely a favourable comparison of Germany's government to Britain's, stating “as Britain begins

\footnotetext{
145 "Blairs aims to skew Bonn-Paris axis," Guardian, June 6, 1997.

146 "All of us together now," Guardian, June 9, 1997.

147 "Road from Amsterdam must take sharp turn," Guardian, June 16, 1997.
} 
to experiment with a more decentralized domestic system of government, it has much to learn from Germany.",148

As previously mentioned, Guardian coverage of the Nice focal point was generally more positive than negative, and in fact there were no articles coded as purely negative. Neutral articles from the Nice summit focused on summit happenings, and particularly on Germany and the contentious issue of vote reweighting in the Council of Ministers. On this topic, articles run by the Guardian indicated that the Germans were justified in asking for increased voting weight in order to reflect a greater population, and French stubbornness was questioned. Although the number of non-neutral articles for the Nice focal point was low in general, some observations can be made nonetheless. Whereas coverage from Amsterdam often portrayed France and Germany together and in generally sinister terms, coverage from Nice tended to deal with the two separately, and in this context, the newspaper was generally well-disposed towards Germany. There were two articles coded as neutral-negative from the time surrounding the Nice summit, both of which complained about German power, but in the context of the big powers reinforcing their position over the small, much the same as in the Independent. Neutral-positive articles tended to view Germany as a helpful or benevolent partner in the EU:

In this [Tony Blair] has an ally in the German chancellor, Gerhard Schroder. A double-ally in Nice yesterday as they devoted much of the day to sorting out the injured feelings of smaller EU states angry at the reweighting of voting strength... They had spent most of yesterday thrashing out the `bigs" versus `smalls" voting issue in which the bigs - notably Britain and Germany - weighed in to play a helpful role having already got what they wanted. ${ }^{149}$

148 "Relief at Labour triumph starts to melt Europe's ice," Guardian, May 9, 1997.
149 "A long, long, weekend on the Med," Guardian, December 11, 2000. 
Although it can be seen from Figure 2.16b that relevant coverage was limited and generally neutral during June 2001, there was nonetheless a continuation of this theme in a neutral-positive article that stated, "the [Irish] Republic has benefited mightily from subsidy, mainly courtesy of German taxpayers."150

The article coded as pure positive from the Nice summit noted that "Germany made a heroic sacrifice, unimaginable from France or Britain, in not insisting on the highest weight, to reflect its $20 \mathrm{~m}$ extra population" and, recalling the wariness displayed toward Franco-German integration plans during the Amsterdam summit, went on to say "an IGC, led by Germany, to establish the borderlines between the EU and national governments in this federation of nation states is an opportunity not a threat." ${ }^{, 151}$ The positive treatment of Germany in this case leads us to hypothesize that the Guardian is more negatively disposed towards Germany in the context of the Franco-German axis than it is otherwise, or that by this point Anglo-German relations had warmed to the point where the Guardian generally reported favourably on Germany. Examination of the findings in the next chapter will allow us to see to what extent either of these positions hold up.

Guessing at trends for the Economist over the three focal points examined so far is somewhat problematic because of its low number of relevant articles for the European integration focal points ( 12 for Amsterdam and 4 for Nice). Examination of the following figures indicates that there exists no real correlation, although it does show that, like the Guardian, non-neutral coverage of Germany at Amsterdam was generally negative, while that at Nice was more positive. Figures $2.19 \mathrm{a}$ and $2.19 \mathrm{~b}$ indicate that Economist coverage

150 "Emerald Escape- Stop the treaty, we want to get off," Guardian, June 11, 2001.

151 "Everyone was a winner at the Battle of Nice," Guardian, December 12, 2000. 
was neutral prior to the Amsterdam summit, and became negative during the event itself.

No trend line exists for the Nice focal point, as there were not enough relevant articles to generate one. In terms of article focus, the themes are similar to those found for other newspapers so far.
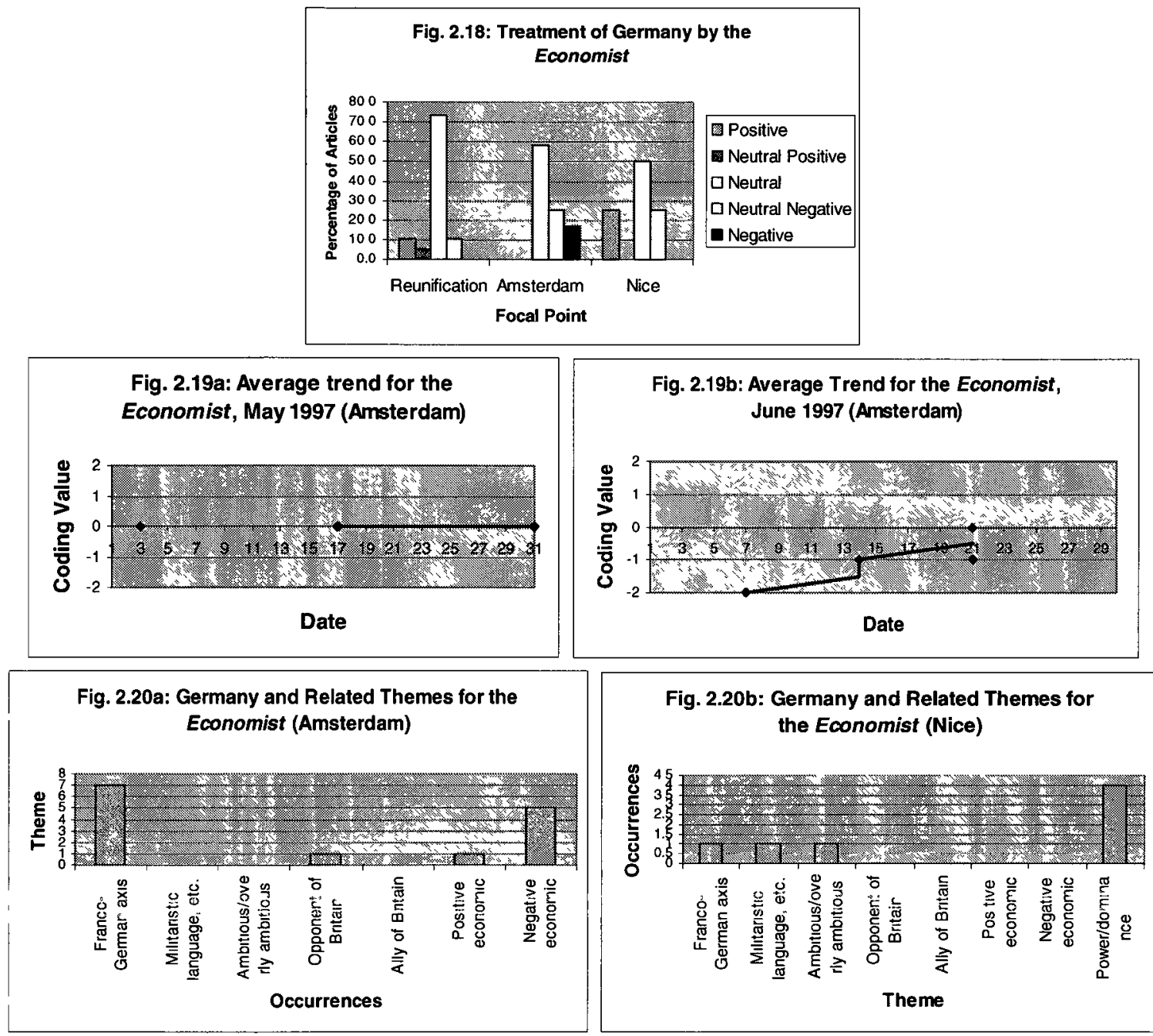

Fig. 2.20b: Germany and Related Themes for the Economist (Nice)

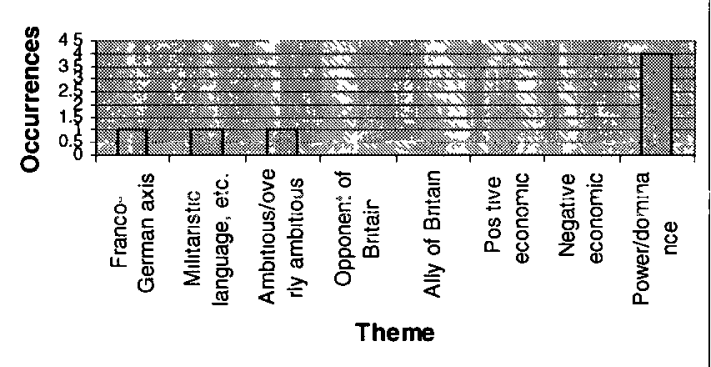

Articles from the Amsterdam focal point contained the common theme of finances, and all negative and neutral-negative articles concerned German economics. Articles from the Nice summit concerned German power, which was viewed positively at the time of the summit itself: 
France will have to accept, under the new dispensation, that it will less often be able to set the agenda for the entire club, while Germany, for its part, has rightly gained power in keeping with its population size. Nobody should be afraid of that. ${ }^{152}$

As can be seen, however, there is within this article a hint that German power generates fear, and indeed we have seen that it is common among all the newspapers examined here to portray Germany as a powerful and potentially threatening entity. One neutral-negative article from the time of the Irish referendum referenced the Nazi period, as the Economist was noted to do during the test case:

Given that some of Germany's most traumatic and triumphant experiences this century have involved their currency-the hyperinflation of 1923 that helped bring the Nazis to power and the inexorable rise of the D-mark after 1945-it is certainly bold to go ahead with so far-reaching a change without first legitimising [the introduction of the Euro] through a referendum. ${ }^{153}$

In sum, despite the relative lack of relevant articles, it can be said that Economist attitudes towards Germany are not generally set as has seemed to be the case with other newspapers. Attitudes here seem to ebb and flow with the situation at a given time, although some themes such as references to the Nazi period continue to recur. A focus on financial and economic concerns also remains evident, although this is expected given the nature of the publication. It should be noted that, despite attitudes of the Economist, Nazi imagery was generally rare in British press coverage of Germany within an EU context, although we have seen that a mistrust of German power, especially in conjunction with France, was generally common.

152 "For all its shortcomings...," Economist, December 16, 2000.

153 "The no vote in Ireland's referendum...," Economist, June 16, 2001. 
$\underline{\text { Section Conclusions }}$

In this chapter, we have made numerous findings regarding the British press and its coverage of Germany on both an overall and individual basis, and from these findings we have been able to arrive at some concrete conclusions and make hypotheses as to future findings. Overall, we have found that British attitudes towards Germany remained proportional in both focal points regarding European integration, and that these findings also compared well to the test case, which was not expected. This allowed us to posit that the degree of positivity and negativity in the British press concerning Germany seems similar regardless of context. We also discovered that non-neutral press coverage of Germany was predominantly negative, although this negativity was generally subdued and not blatant. These findings are in line with our initial hypotheses, and also lend strength to the current scholarship on British press attitudes towards Germany, which are broadly considered to be negative and unrelated to specific context.

In the context of European integration, we defined numerous common themes that emerged, and tracked their appearance and portrayal in individual newspapers across focal points with a view towards examining the image of Germany as it has been constructed by the British press in relation to this process. We examined the nuances of each newspaper, and found that a key focus in all of them for both focal points was the Franco-German relationship, and that this relationship was portrayed as semi-sinister, even in Europhile papers. We saw that in some cases, treatment of Germany improved when it was considered by itself and without its French partner. Themes that remained common to newspapers between the test case and the European integration focal points were also looked at, and we were able to note that there was much less fear of militarism 
and references to World War II in the EU cases, although a certain wariness regarding German power remained. Finally, we were able to make some guesses concerning a newspaper's portrayal of Germany and its stance on European Integration, although nothing clear can be said at this point. Ultimately, the validity of all findings and conclusions made so far will be tested in the following chapter, which concerns the EU constitution.

\section{Eye on Britain: German Press Coverage of the Amsterdam and Nice Summits}

\section{Newspaper Coverage and Interpretation Overall}

We may now turn to the other side of the equation and analyze German attitudes towards Britain as they appeared in the press during the Amsterdam and Nice focal points. It should be noted that according to online availability issues, data from the Berliner Zeitung is not available for the Amsterdam focal point. This data comes from 38 newspaper articles gathered from the time of the Amsterdam summit, and from 90 taken from the month of the Nice summit and the month of the Irish rejection of the treaty in 2001. Although a comparison between British and German press coverage will be undertaken in greater detail at the end of this chapter, from this information it is immediately obvious that in both cases the German press ran fewer articles mentioning Britain than the British press did mentioning the Germans during the same time period. This difference is more noticeable for the Amsterdam focal point, when the British press ran 104 articles to the German press' 38 , and although the coverage of Nice is more comparable at 90 article to 116 , this agrees with the former hypothesis that the British are more interested in Germany's role in the EU than the Germans are in Britain's. 

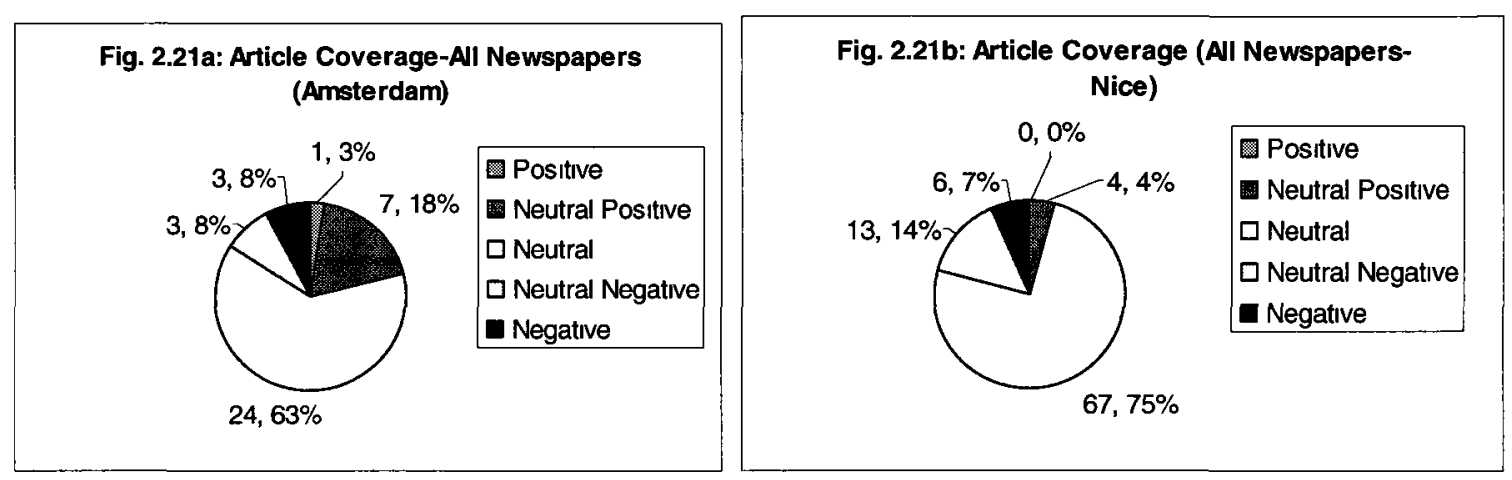

Examination of Figures $2.21 \mathrm{a}$ and $2.21 \mathrm{~b}$ shows that there is limited correlation between press attitudes during each focal point. The percentage of pure positive and pure negative articles is similar ( $3 \%$ to $0 \%$ and $8 \%$ to $7 \%$ respectively), although there is significant difference between the neutral-positives ( $18 \%$ to $4 \%$ ) and neutral negatives ( $8 \%$ to $14 \%$ ), and it is clear that non-neutral coverage tends towards the positive at Amsterdam and towards the negative at Nice. The majority of press coverage continues to be neutral, although there is a significant difference between the numbers here as well (63\% to 75\%). These findings only allow us to state that:

Unlike the reverse case, German press coverage of Britain during the Amsterdam and Nice focal points suggest that attitudes within an EU context generally do not remain consistent and vary over time.

In fact, this assertion seems to be borne out regardless of any context. Recall how Figure 1.8 from the previous chapter illustrated that the test case contained no articles that were remotely positive: 


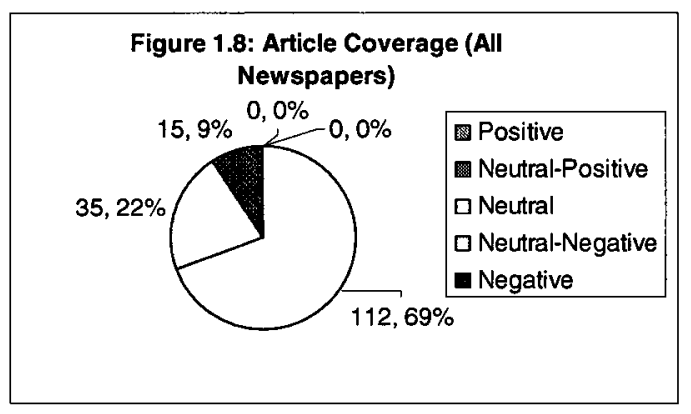

Again, we can see that although the majority of coverage was neutral, Figure 1.8 bears little resemblance to Figures 2.21a and 2.21b. This comparison allows for some interesting findings, the most obvious of which is:

The degree of positive and negative attitudes that the German press expresses towards Britain is generally inconsistent and variation exists even within an EU context.

Despite the above statement however, it seems that:

Although the percentage of positive, neutral-positive, and neutral negative coverage can vary greatly, the percentage of pure negative coverage is remarkably consistent from case to case.

Although this finding may be discredited by the information contained in the final chapter, it is interesting to note that the percentage of pure negative articles from each of the 3 cases examined so far differ only by a maximum of $2 \%$ from each other $(9 \% 8 \%$, and $7 \%$ respectively). Why this would be the case is unclear. Finally,

It seems that the German press is more inclined to view Britain positively within an EU context than outside of it, although this cannot be proven definitively.

This is in line with the hypothesis which guessed that reporting within an EU context would somehow differ from non-EU coverage. However, with only one non-EU test case, we cannot say for certain that this is a general truth, as it may be that the test case was 
more negative than would have been desired, as was hypothesized in the previous chapter.

Moving on to an attitude breakdown by newspaper, once again the only clear trend is that the majority of coverage from each newspaper in each focal point, with the exception of Der Spiegel, is neutral,
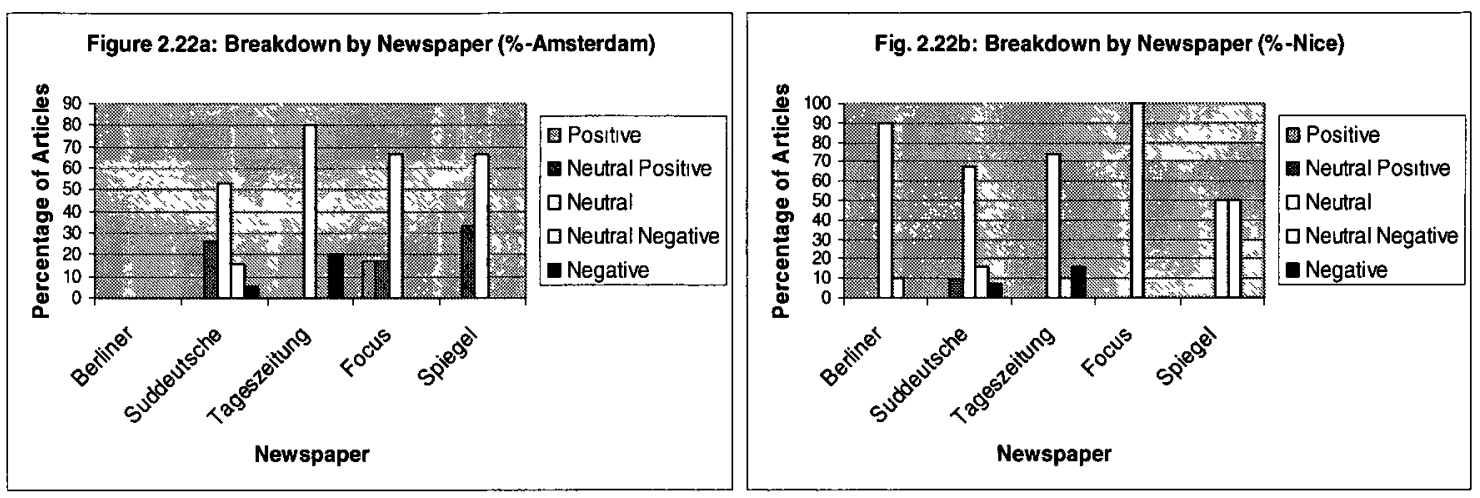

This finding is also consistent with Figure $1.9 \mathrm{~b}$ from the test case:

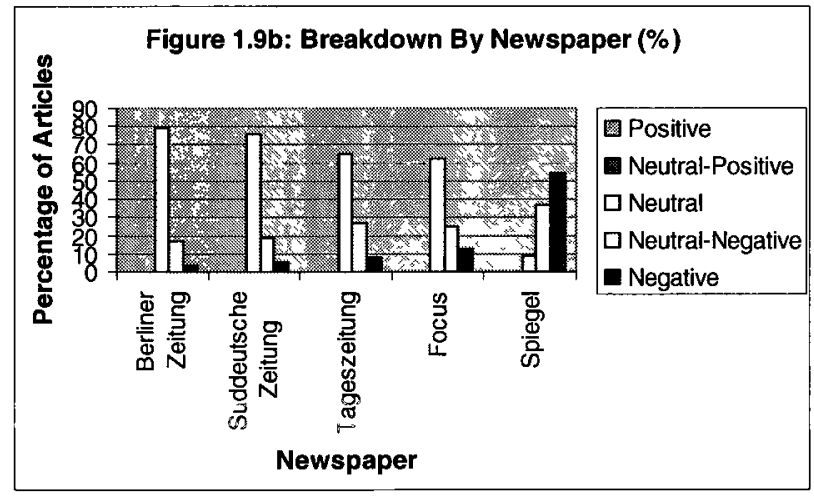

We are thus able to say,

With the exception of Der Spiegel, the majority of press coverage for each newspaper during the time period for all three focal points was neutral.

However, recalling the findings for the German press from Chapter 1, we cannot agree that when neutral articles are discounted that press coverage is generally negative for a given focal point, as we have seen that coverage from Amsterdam would be more 
positive than negative. We can also no longer say with certainty that negativity or positivity is subdued (i.e. mostly neutral-positive or neutral-negative), as there are numerous examples in the figures shown above where pure positive or pure negative articles equal or outweigh the neutral-positive or neutral-negative, but we can say that this still generally seems to be the case. This lets us say

The degree of positive and negative attitudes that each newspaper expresses towards Britain is also generally inconsistent from one focal point to the next, and variation exists even within a similar context, although a tendency towards subdued attitudes is still evident.

Although it might not be immediately apparent from the graphs, however, the relative negativity of the three broadsheets (Berliner Zeitung, Süddeutsche Zeitung, and Tageszeitung) remains consistent across all three focal points, as was found to be the case in the British section. In each case, the Tageszeitung ran proportionally more negative articles overall than the Süddeutsche Zeitung, which ran more than the Berliner Zeitung. The negativity of FOCUS and Der Spiegel is more inconsistent, and thus the newspapers do not fit into this scale. We can thus also include as a general finding that

The relative negativity of three daily broadsheets (Berliner Zeitung, Siiddeutsche Zeitung, Tageszeitung) remains consistent through all focal points, although the actual percentage of attitudes may vary greatly from one to the next.

Ultimately these findings tell us that there is little consistency regarding attitudes towards Britain in the German press, even within an EU context. This differs markedly from the findings of the British section above, and suggests that German journalists are more likely to portray the British according to a given situation rather than according to 
previously-held attitudes and beliefs, which would seem to be the case with British journalists.

\section{Individual Trends and Themes}

As was the case in the British section of this chapter, a similar list of broadly emphasized themes has been created for the German press for the Amsterdam and Nice focal points, in order to assist in our assessment of image construction in the German press. There were five such themes found to be shared between the Amsterdam and Nice summits (and Irish rejection), though there was one additional theme that was present during the Amsterdam coverage but not for that of Nice. The common emphases regarding Britain were found to be:

1) Britain as an opponent of Germany or Germany desires.

2) Britain as an ally or friend of Germany.

3) Britain as a potentially constructive partner in the European integration process.

4) Britain as being a general laggard, inhibitor, or blocker of European integration initiatives.

5) The British people as isolationist, Eurosceptic, or anti-EU.

The emphasis at Amsterdam that did not recur at Nice was:

6) The British as being stingy with their money.

The first publication to be examined here is Der Spiegel. Analysis of this magazine for the Amsterdam and Nice focal points is somewhat problematic due to the 
very low number of relevant articles found in each case ( 3 for the Amsterdam summit and 4 for the Nice focal point). This lack of data means that it is not possible to create charts that display clear trends over time, but what is clear is that Der Spiegel shows little consistency in its attitudes towards Britain either between these two focal points, or with reference to the test case. This finding is in line with our previous findings for the German press overall. Recalling that this was the most unambiguously negative publication in the test case, it is somewhat surprising to note that neither coverage of the Amsterdam nor Nice focal points contained pure negative or pure positive articles. Figure 2.23 illustrates this:

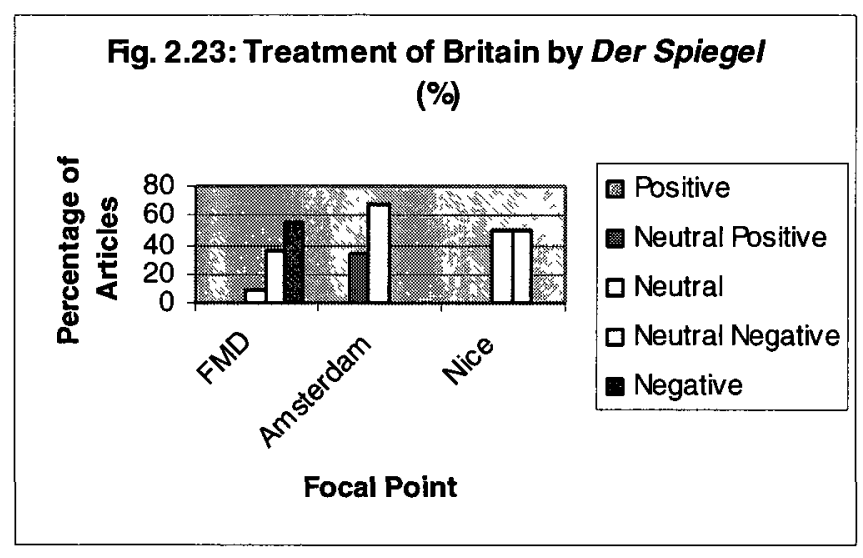

We can also see that Der Spiegel portrays Britain in a moderately positive light during the Amsterdam summit, and in a more negative light during the Nice focal point. This finding also coincides with our overall findings for the German press, as mentioned at the beginning of this section. What does remain constant in coverage between focal points is Der Spiegel's tendency to use stereotypes when describing the British. This will become evident upon a closer examination of the articles from Amsterdam and Nice.

Coverage from Amsterdam was made up of 3 articles only, two of which were neutral, and one of which was neutral-positive. Both neutral articles came from June and 
discussed finances and the introduction of the Euro, with one stereotyping the British and their view of the continent as "a bit eccentric,", 154 which is in line with our findings from the previous chapter. The remaining neutral-positive article came from May and applauded the British government's decision to become more involved in Europe, and once again stereotyped the British, this time casting them as typically isolationist and anti-EU,

How happy the nation seemed to break out of the Splendid Isolation towards which the eurosceptic Tories had tended. Instead of the stereotypical "No", Great Britain's partners heard Douglas Henderson, its Minister for Europe in Brussels, suddenly assure cooperation, with the continent to enjoy "top priority" status with his government in the future. ${ }^{155}$

This suggests a willingness to view Britain more positively when it takes actions that further the European integration project, which is in line with the pro-European nature of Der Spiegel. This seems to be borne out in the coverage of the Nice focal point, which takes the opposite stance when Britain acts against integration. Coverage from this focal point was made up of 4 articles, two of which were from the time of the summit itself, and two of which concerned the Irish rejection. Both articles from the December summit were neutral in nature, and both concerned voting weights in the Council of Ministers, where Great Britain was simply mentioned as one of the "Bigs". The two articles from the Irish rejection were neutral-negative and lamented some of Britain's anti-European measures, specifically in providing money for the Irish "no" campaign,

154 "Die Angst vor dem weichen Euro- Vom Euro gejagt," Der Spiegel, June 16, 1997. German: etwas exzentrisch.

155 "Der furiose Start von Tony Blair- jeden Ruckfall verbaut," Der Spiegel, May 12, 1997. German: Wie beglückt schien die Nation aus der Splendid isolation auszubrechen, zu der die euroskeptischen Tories geneigt hatten. Statt des stereotypen "No" hörten Großbritanniens Partner den nach Brüssel entsandten Europaminister Douglas Henderson plötzlich versichern, die Zusammenarbeit mit dem Kontinent genieße künftig "die höchste Priorität" seiner Regierung. 
and Tony Blair's rejection of "stronger institutions or even an EU constitution." "156 This focal point did not contain the same use of stereotyping as did the Amsterdam coverage.

Given the lack of relevant articles, it is hard to say anything definitive concerning Der Spiegel and the list common themes mentioned above, nevertheless, the magazine scores as follows:
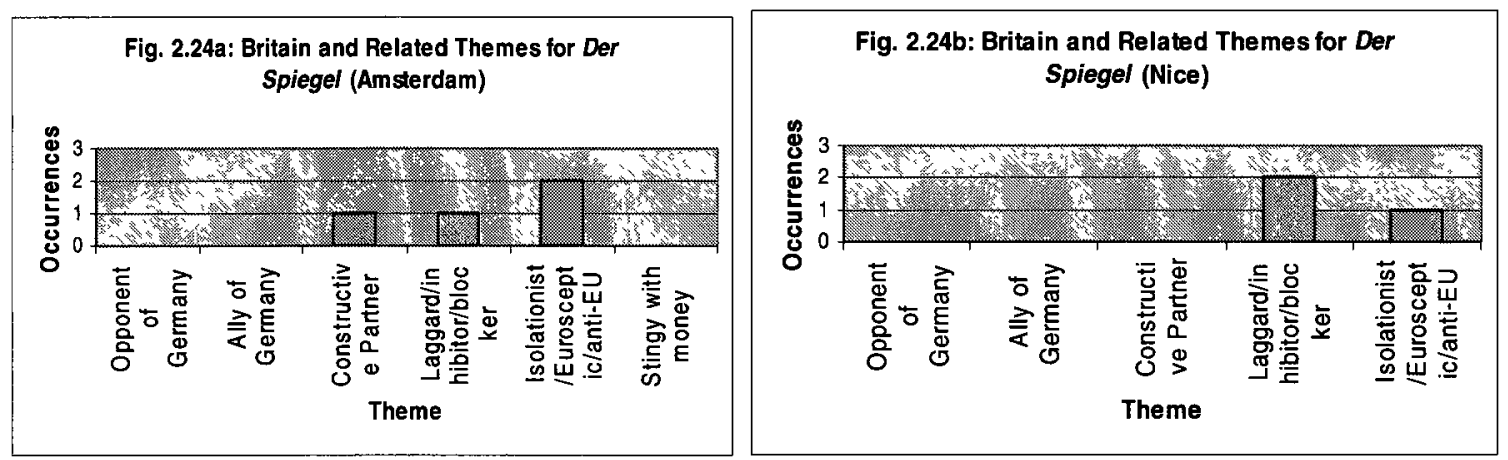

Both focal points therefore portray the British as inhibitors or blockers of the EU, and as we have seen, when this behaviour is reversed, the magazine comments more positively on Britain, and when it recurs it is more negative. This suggests that Der Spiegel's attitudes towards Britain will depend on how that country acts in the integration project. The findings from the next chapter will help to prove or disprove this assertion.

Like Der Spiegel, relevant articles in FOCUS were relatively scarce for the Amsterdam and Nice focal points, with the former having six and the latter having four. There were, however, sufficient relevant articles run during the Amsterdam summit in June 1997 that an average trend could be graphed for this month, although this was the only month where this was the case. Also like Der Spiegel, FOCUS shows little consistency in its attitudes towards Britain either between the Amsterdam and Nice focal points, or with reference to the test case. 

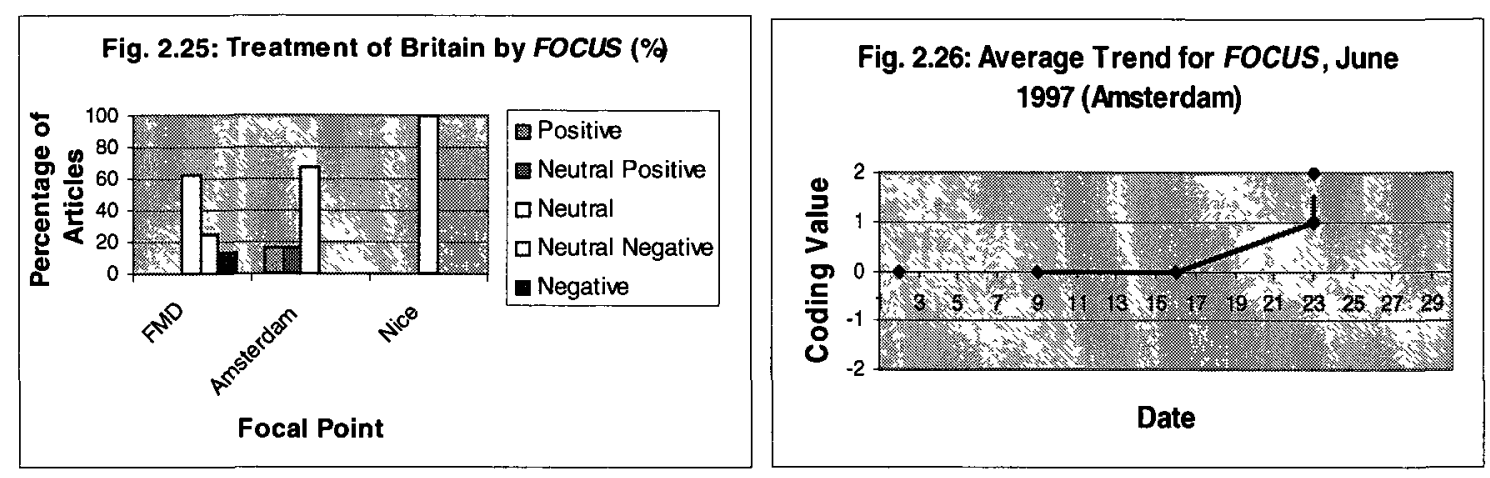

As can be seen from Figure 2.25, non-neutral coverage of Britain during the Amsterdam summit was generally positive, as was the case for Der Spiegel, and the German press in general. Figure 2.26 shows how the trend for this focal point goes from neutral to positive during the events of the summit. Note also that coverage for Nice was entirely neutral. Interestingly, there was no negative coverage for either of the EU focal points, despite the fact that FOCUS was one of the more negative newspapers in the test case. This could be due to the relatively low article count, or it could be the case that FOCUS is generally more neutrally disposed towards Britain than the article coding from the test case would indicate, and recall in fact that this was hypothesized in the previous chapter.

In terms of the common themes listed above, there are no comparisons to be made between the findings for Amsterdam and Nice focal points, as no emphases are shared between the two.
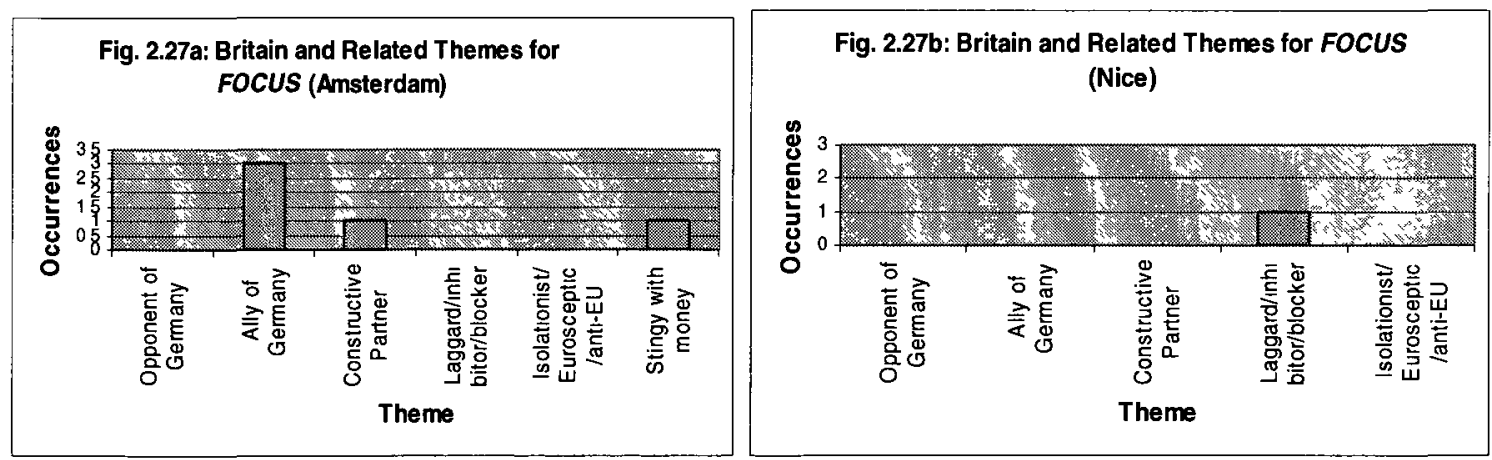
As can be seen in Figure 2.27a, individual articles from the Amsterdam focal point tended to emphasize Britain as an ally or partner of Germany, and in fact most of the six articles specifically focused on Tony Blair. Neutral articles tended to examine what his election meant for Europe, and also discussed Chancellor Helmut Kohl's hopes for British help at the upcoming summit. Amsterdam contained one pure positive and one neutral-positive article, both of which concerned Tony Blair. The pure positive article noted that Blair worked well with Chancellor Kohl, and further complimented the outgoing John Major for his generosity. ${ }^{157}$ The neutral-positive article contained a report on a warming of Anglo-German relations due to Blair's efforts. ${ }^{158}$ From these, we can get a sense of the renewed optimism that Britain's European partners felt after the election of the Labour government in May 1997. This suggests that, like Der Spiegel, FOCUS is willing to comment positively on Britain when it works towards the goal of European integration.

Coverage for Nice was evenly split between December 2000 and June 2001, with two relevant articles appearing in each time period. All of these articles were coded as neutral and passively reported on the events of the summit and Irish rejection, with no clear emphasis or recurring themes. Looking back to Figure $2.27 \mathrm{~b}$, we can see that an article from the Nice coverage contained the theme of Britain as an inhibitor or blocker of EU initiatives, but this also received a neutral coding value. This suggests that, unlike Der Spiegel, FOCUS may not portray Britain negatively if it acts in anti-EU ways. This adds further support to the notion which has been mentioned earlier that FOCUS is generally neutrally or positively disposed towards Britain.

157 “EU Gipfel- Kohls Kehrtwende," FOCUS, June 23, 1997.

158 "Wo die Chemistry stimmt- Kohl und Blair," FOCUS, June 23, 1997. 
The same can not be said for the Tageszeitung. While this newspaper, like Der Spiegel and FOCUS, ran relatively few relevant articles during the time period for both focal points (10 for Amsterdam and 19 for Nice, as compared to 37 for the FMD crisis), it was also the first to remain relatively consistent in its treatment of Britain across both EU focal points as well as the test case, and this treatment was generally negative.

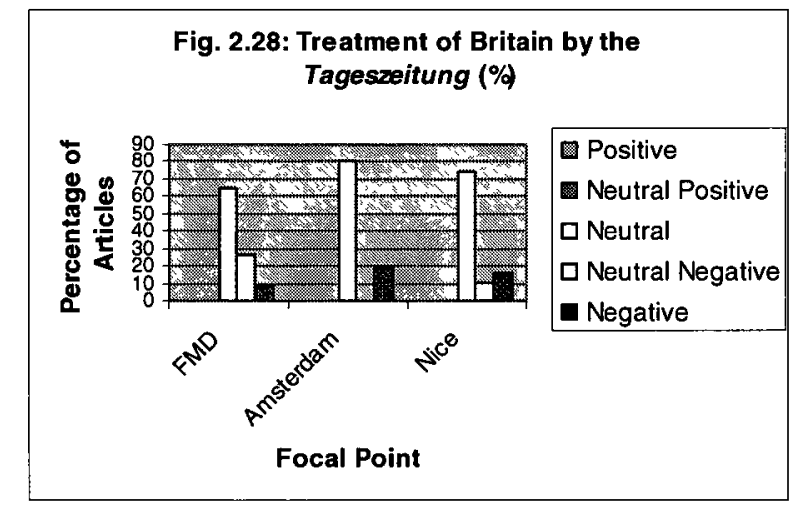

As can be seen from Figure 2.28, none of these three focal points contained any articles coded as positive or neutral-positive, allowing us to say that in general the Tageszeitung seems to be negatively disposed towards Britain when not simply passively reporting on a given situation. Further, this figure also tells us that both EU focal points contained more purely negative articles than neutral-negative, thus differing from the test case. This allows us to say that the Tageszeitung seems more inclined to be blatantly negative when discussing Britain within the context of European integration. Proportionally, coverage of Britain was also more purely negative for the Amsterdam focal point than it was for Nice, which differs from the findings in both Der Spiegel and FOCUS.

Too few articles exist for May 1997 to graph a trend line for this month, but for the sake of accuracy it will be stated that two articles were run, one on 16 May coded as 
negative, and the other on 23 May coded as neutral. The trend lines for the remaining months are as follows,

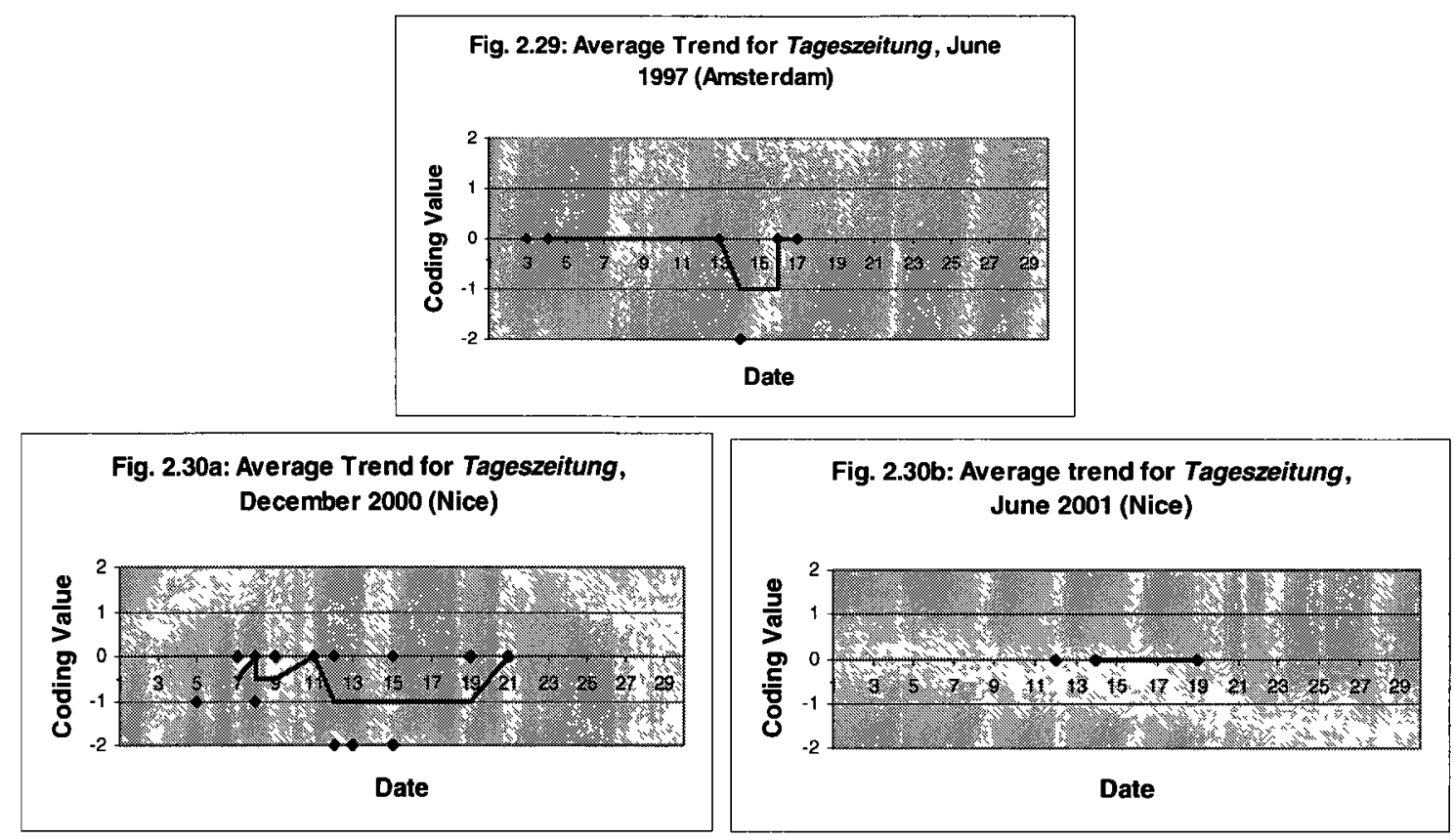

Figure 2.29 shows a relatively neutral trend leading up to the Amsterdam summit, with a sudden brief negative drop during the summit itself (although only one negative article was present). The trend during December 2000 and the Nice summit, as shown in Figure 2.30a, shows coverage that was generally negative for a longer period, while relevant articles from the time of the Irish rejection were entirely neutral. In terms of the common themes listed above, the Tageszeitung scores as follows,
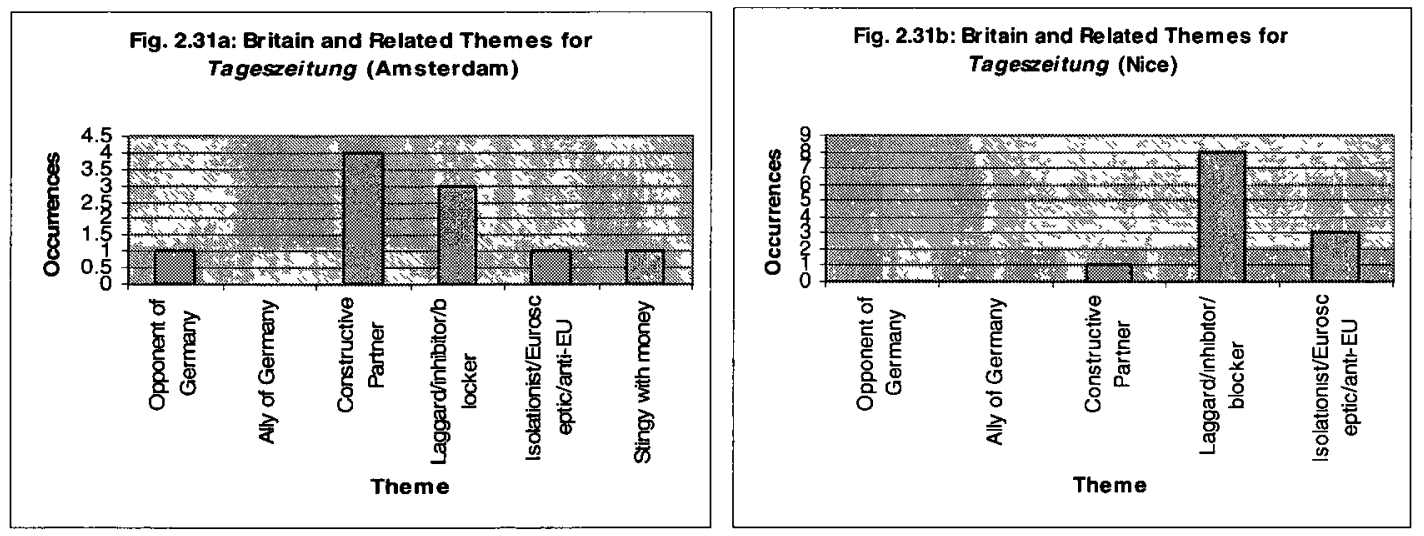
We can see that, although there is a particular emphasis on Britain as a constructive partner during the Amsterdam summit, reference to Figure 2.28 tells us that this did not translate into any positive or neutral-positive articles, and this theme had decreased in importance by the time of the Nice summit. As a side note, it is interesting to find here that while Britain was discussed as a possibly constructive partner in the EU, it was never portrayed as a friend or ally of Germany. Instead, a theme that scored consistently high for both focal points was that of the British as laggards, blockers, or inhibitors in the EU project, which is similar to the coverage we have seen in Der Spiegel. As we shall see, the Tageszeitung chose to display this theme in a negative light.

As mentioned earlier, there were only ten relevant articles run during the time period for the Amsterdam focal point, with eight being coded as neutral and two as pure negative. The neutral articles passively reported on scattered topics from the summit, including Euro entry and plans for foreign policy, while both of the pure negative articles lamented the British lack of enthusiasm for the European integration project. The first article, which was run on 16 May, specifically targeted the British Greens, saying, "not all green parties are motivated by the necessary commitment to Europe- the British and Swedish party friends are even quite chilly about it." ${ }^{, 159}$ The second, which was run shortly before the summit itself, lamented the British backing out of the Social Charter after having promised to deal with it. ${ }^{160}$ We can thus see that the Tageszeitung, a Europhile newspaper, will portray Britain negatively if it perceives a lack of commitment.

\footnotetext{
159 "Die kleine Volksfront fuer ein Euro-Referendum," Tageszeitung, May 16, 1997. German: Nicht alle Grünen-Parteien sind von dem erforderlichen Europa-Engagement beseelt - die britischen und schwedischen Parteifreunde stehen dem gar äußerst frostig gegenüber.

160 "Sozialcharta auf Eis," Tageszeitung, June 14, 1997.
} 
This treatment also continued during the Nice focal point. As mentioned earlier, 19 relevant articles were run for this focal point, three of which were from the time of the Irish rejection and all of which were neutral in nature. Coverage from the summit itself was made up of 16 articles, two of which were neutral-negative, three pure negative, and eleven neutral. The neutral articles once more dealt with scattered topics from the summit, though there was some continued focus on vote reweighting in the Council of Ministers. The two neutral negative articles contained no shared themes, with one reporting with a seeming mild annoyance on certain British newspapers taunting their French rivals before the summit, and the other containing a secondhand report on the dismal state of British healthcare. Two of the three negatives, however, criticized Britain for being stubborn and unwilling to yield national power, with either the direct or indirect implication that this was damaging for Europe. One stated that "the big loser of Nice is Europe. Guilt for this goes above all to the big powers like France and Britain." ${ }^{161}$ The final article was similar, except it only mentioned the Prime Minister and his "intransigence" on tax questions. ${ }^{162}$ It should be noted in the earlier examples that when Britain was being criticized for being anti-European, other countries (such as France) were also mentioned at the same time, suggesting that the Tageszeitung does not specifically single out Britain for negative treatment when it acts in an anti-European manner. In closing with our examination of the Tageszeitung, we can thus say that it is generally consistent in being negatively disposed towards Britain, though it is more likely to portray it (or any country) in a negative light if it acts in a way that is less European than might be desired.

\footnotetext{
161 "Die anderen," Tageszeitung, December 13, 2000. German: Der große Verlierer von Nizza ist Europa. Schuld daran sind vor allem die Großen wie Frankreich und Großbritannien.

162 "das ende des deutsch-französischen gleichgewichts," Tageszeitung, December 15, 2000.
} 
As previously mentioned, because of source availability issues, coverage for the Berliner Zeitung is not available for the Amsterdam focal point. However, a reasonable number of relevant articles exist for the Nice focal point (20), and we are still able to make a number of findings with the available information.

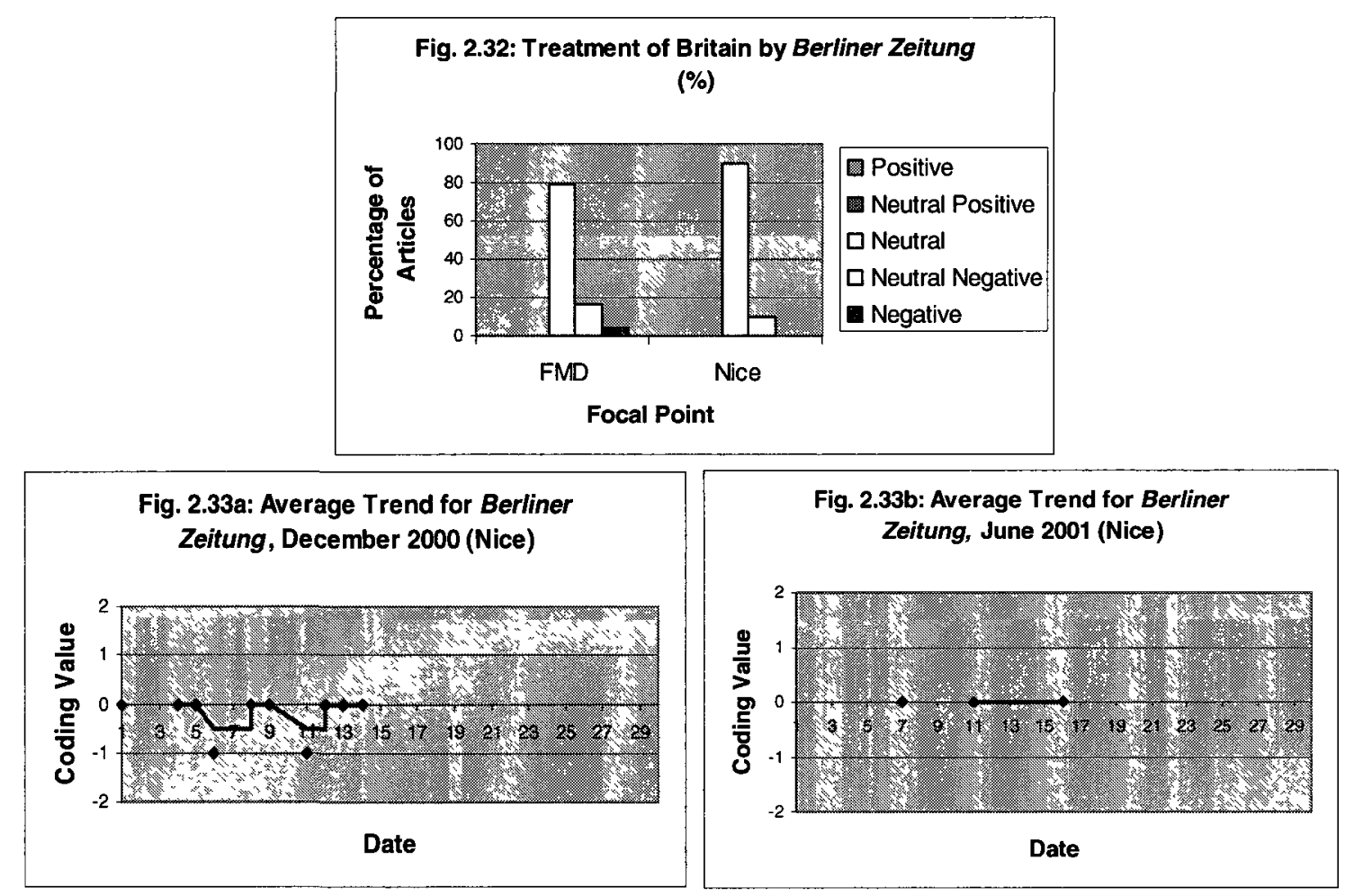

We can see from Figure 2.32 that coverage of Britain remains quite consistent between the Nice focal point and the test case. The latter was overall the more negative case, but we can see that neither contains either neutral-positive or pure positive articles. Both cases are also marked by a very high neutral count, with $80 \%$ of coverage being coded this way for the FMD focal point, and $90 \%$ for Nice. Figure 2.33a from the time of the Nice summit shows an oddly regular trend dipping towards neutral-negative from what is generally a neutral position, while coverage from the time of the Irish rejection is entirely neutral. Even without information from the Amsterdam focal point, we can guess that the Berliner Zeitung is generally neutrally disposed towards Britain, but we can also say that 
it has a tendency to be negatively disposed when not simply passively reporting on a given situation, in much the same way as our findings for the Tageszeitung.

Also similar to the Tageszeitung was the Berliner Zeitung's tendency to portray the British as laggards in the integration process, which it also chose to emphasize negatively, although not to the same degree as the Tageszeitung. At this point, we can begin to see that the image of Britain that is maintained in the German press in this context is one of a country that is at odds with the European integration process.

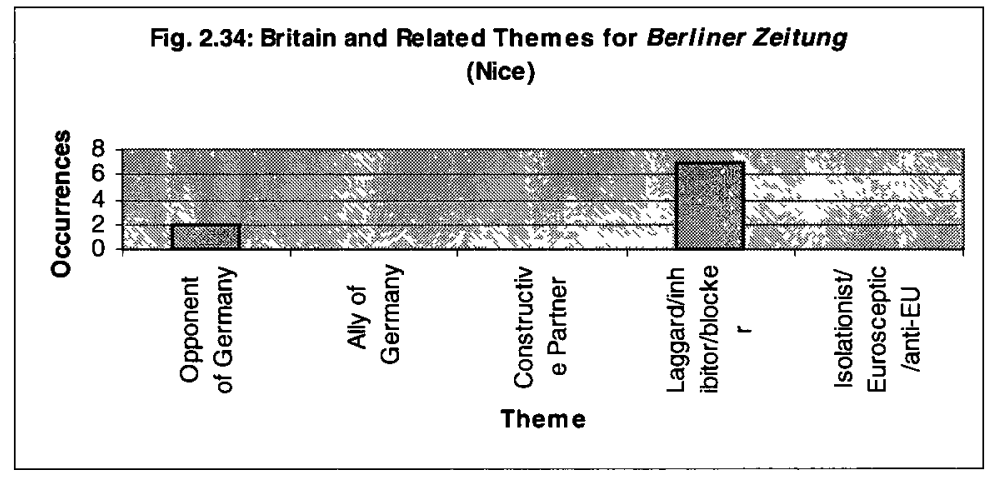

For the Nice focal point, the neutral articles tended to report on the usual summit happenings, although there was also a tendency in these articles to focus on EU measures that Britain had rejected, which was not necessarily a specific focus of the other newspapers under examination. As mentioned previously, the Berliner Zeitung occasionally chose to emphasize Britain's anti-EU measures in a semi-negative light. While this focal point contained no pure negative articles, two neutral neutral-negatives existed. The first of these contained a report of the British denying that they had set up "insurmountable hurdles" prior to the summit, and generally painted the British government as being evasive concerning critical European questions. ${ }^{163}$ The second article indicated displeasure with Britain pursuing its own national interests to Europe's

163 "Großbritannien weist Vorwürfe Prodis zurück - Sprecher umreißt Position Londons vor NizzaTreffen," Berliner Zeitung, December 6, 2000. 
detriment, although, as with the case of the Tageszeitung during the Nice focal point, other powers were cast in a negative light as well.

Despite the relatively limited information, we can thus say of the Berliner Zeitung that it is generally consistent in its attitudes towards Britain both within and outside of a European context. Coverage tends to be overwhelmingly neutral, but there is still a tendency to portray British anti-EU acts in a semi-negative manner, and to cast the country as a laggard within the integration process.

Finally, the Süddeutsche Zeitung contained a higher number of relevant articles for both EU focal points than any other newspaper examined here, with 19 coming from the time of the Amsterdam summit and 43 from the Nice focal point. The Süddeutsche Zeitung is also noteworthy because it contained a reasonable number of articles from the time of the Irish rejection (8) that were also varied with respect to their coding value; we have seen so far how the other newspapers have produced relatively few and mostly neutral articles from this time period. Comparison of coverage across all three focal points shows us that there are both similarities and differences in the ways that the Süddeutsche Zeitung displays attitudes towards Britain:

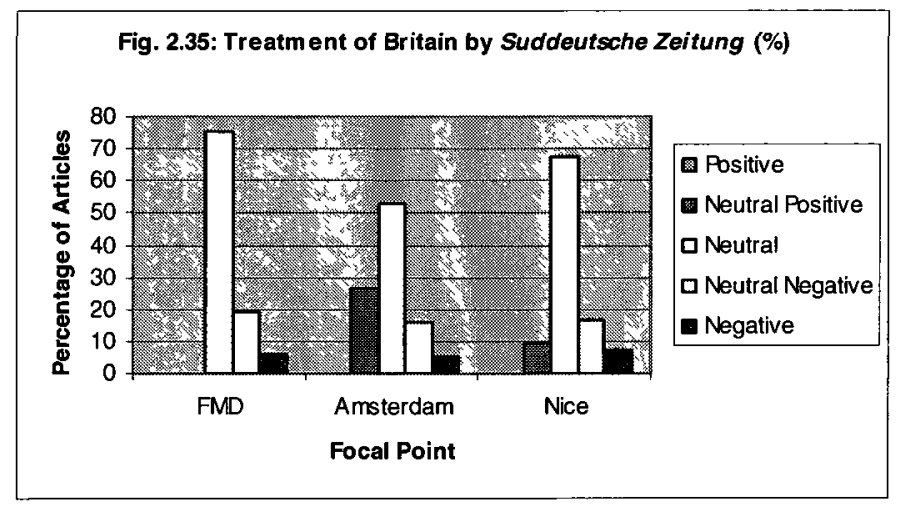

What is noticeable from Figure 2.36 is that while the test case contained no neutral positive or pure positive articles, both EU focal points contained a percentage of neutral 
positives, making it the first of the major German dailies examined here to contain positive reporting of any sort. This also indicates that the Süddeutsche Zeitung is willing to discuss Britain in positive terms within the context of European integration- in fact, the number of neutral-positive articles from the Amsterdam summit outweighs the combined number of negatives, although the negatives outweigh the positives during the Nice focal point. What is also noteworthy is that the proportion of negative and neutral-negative articles remains almost identical in all three focal points. This suggests that while the degree of positivity exhibited by this newspaper towards Britain may fluctuate depending on context, negative attitudes remain constant.

Looking to Figures 2.36 and 2.37, we can see that there is a tendency of the Sïddeutsche Zeitung to report either positively or neutrally on Britain during time periods when European issues are not at the forefront, but there is a definite negative trend that emerges surrounding the time of the summits.
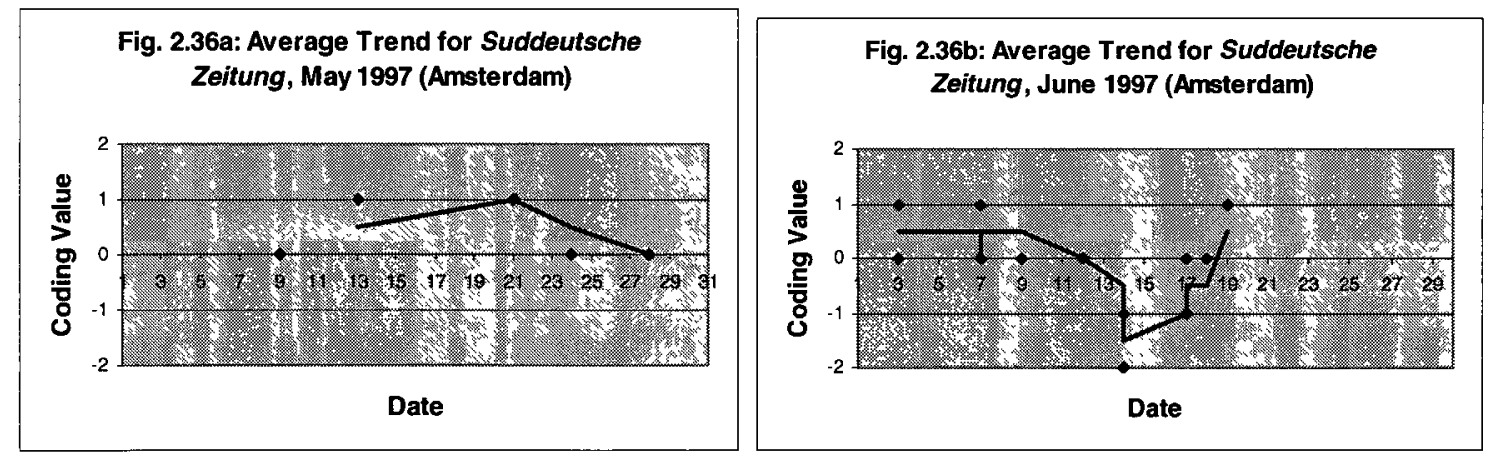

Fig. 2.37a: Average Trend for Suddeutsche Zeitung, December 2000 (Nice)

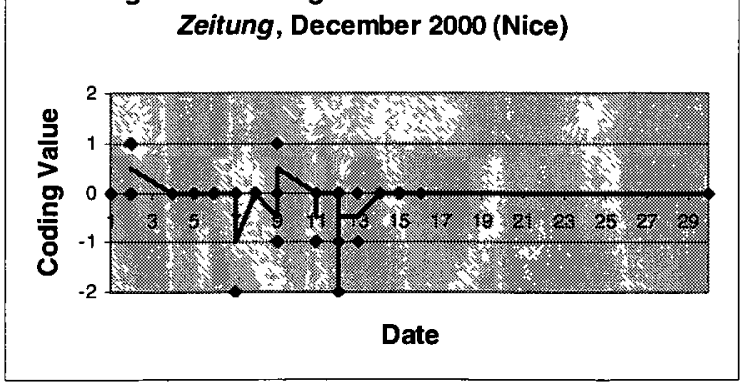

Fig. 2.37b: Average Trend for Suddeutsche Zeitung, June 2001 (Nice)

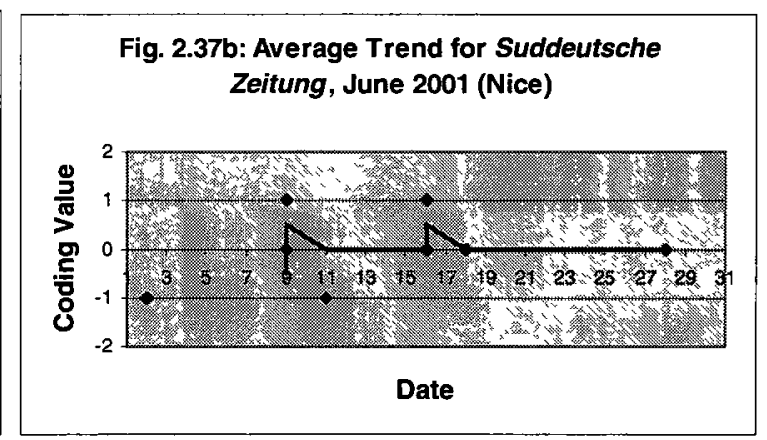

In terms of the shared list of themes, the Süddeutsche Zeitung scores as follows, 

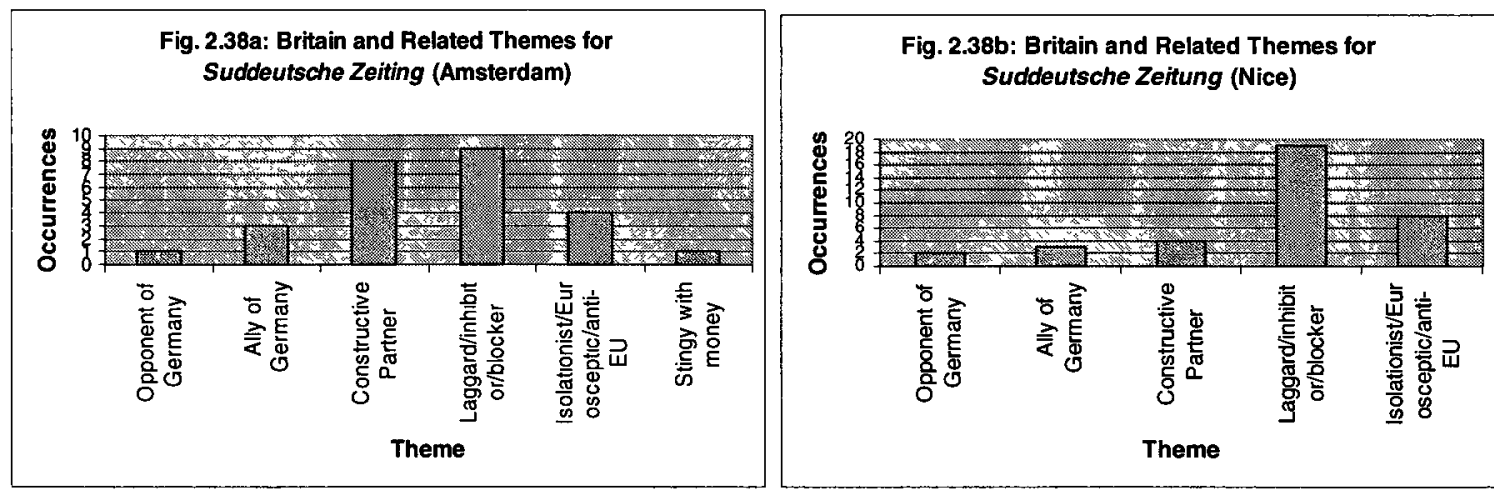

We can see from Figure 2.38a that the Amsterdam summit scores high for portrayals of Britain both as a constructive partner and as a laggard in EU integration. As we shall see shortly, this newspaper is quite unambiguous in its attitudes, with articles concerning the former tending to be coded as positive, and those with the latter tending to be negative. The same is true for coverage at the Nice summit, and looking back to Figure 2.35 , we can see that there is an almost direct correlation between the drop in the "constructive partner" theme and articles coded as neutral-positive. At Nice, the theme of Britain as a laggard in the EU project remains relatively high, and negative coding remains consistent.

In terms of individual article coding, the Süddeutsche Zeitung remained quite consistent and straightforward through both EU focal points. Most neutral coverage at Amsterdam simply dealt with information on the summit, and, as mentioned earlier, the vast majority of neutral-positive articles contained the theme of Britain being a constructive partner in the European project, which was especially intertwined with the new Labour government. Articles like this were either secondhand reports of positive events, or contained an undertone of satisfaction and a willingness to give Britain the benefit of the doubt: 
It almost seems as though the election victory of Labour in London would give the slow negotiations a push. The new British government has set out to work constructively in the EU... Of course, the objective obstacles to the success of reform will not be gone by tomorrow... However, it is too easy to always push the buck to London, as blockers also sit in other European capitals. ${ }^{164}$

In similar fashion to the Tageszeitung and Berliner Zeitung, most neutral-negative articles dealt with British obstructionism. One such secondhand report implied that the British were the main blockers of EU reforms and cast them in a quite negative light:

SZ: Where are the biggest blockers to EU reform currently located?

Brok: Everywhere. Naturally the British have problems with the abolition of border controls or defence policy, like the integration of the Western European Union in the EU treaty, but other countries also have their own preferences and egotistical interests. ${ }^{165}$

The pure negative article continued this theme as well, commenting like the Tageszeitung on broken British promises concerning the Social Charter. ${ }^{166}$

Coverage from the Nice focal point followed generally the same trends, with neutral articles tending to recount events at the summit and neutral positives expressing hope that Britain would play the role of constructive partner. Like previous newspapers, there was a heavy emphasis in neutrally-coded articles on the measures that had been rejected by Britain. Neutral-negatives once more portrayed the British as obstructing European initiatives, and a hint of the stereotyping that we saw in the test cases emerges again. A report on attitudes towards Europe noted that "the British naturally behave as

\footnotetext{
164 "Faule Kompromisse," Süddeutsche Zeitung, May 21, 1997. German: Fast scheint es so, als hätte der Wahlsieg von Labour in London den schleppenden Verhandlungen einen Schub gegeben. Die neue britische Regierung ist mit dem Anspruch angetreten, konstruktiv in der EU mitzuarbeiten... Freilich sind die objektiven Hindernisse für das Gelingen des Reformvorhabens nicht von heute auf morgen verschwunden...Außerdem ist es zu einfach, den Schwarzen Peter stets nach London zu schieben. Die Blockierer sitzen auch in anderen europäischen Hauptstädten.

165 "Die Blockierer sind uberall," Süddeutsche Zeitung, June 14, 1997. German: SZ: Wo sitzen derzeit die größten Blockierer der EU-Reform? Brok: Überall. Natürlich haben die Briten Probleme mit der Abschaffung der Grenzkontrollen oder der Verteidigungspolitik sowie der Einbindung der Westeuropäischen Union in den EU-Vertrag. Aber auch die anderen Länder haben ihre Präferenzen und egoistischen Interessen.

166 "Blair will EU-Sozialcharta erst spater umsetzen," Süddeutsche Zeitung, June 14, 1997.
} 
the 'most nationalistic,' with $67 \%$ against any surrendering of sovereignty to the EU."167

The articles coded as negative were more vocal but carried the same theme as the neutralnegatives:

Britain still can't decide whether it wants to play a constructive roll in the future of Europe or not. The British have stubbornly defended their veto right like no other EU member at Nice. ${ }^{168}$

These positive and negative themes were maintained for the period of the Irish rejection.

In closing our consideration of the Süddeutsche Zeitung, we can say that the newspaper was quite consistent in its treatment of Britain during both EU focal points, portraying the country in a positive light when it is perceived to be furthering the European project, and in a negative light when it takes action against this. This latter point was also found to be the case for the other dailies that have been examined, but unlike these newspapers, we have seen that the Süddeutsche Zeitung is more willing to treat Britain positively within an EU context, with positive reporting occasionally outweighing the negative. In terms of negativity, the newspaper is consistent seemingly regardless of the context, and we have seen how a tendency to resort to stereotypes is maintained with the test case.

\section{$\underline{\text { Section Conclusions }}$}

In closing this section, we have discovered a number of things. We have seen overall that positivity and negativity in German press attitudes is inconsistent from one focal point to the next, although the majority of coverage tends to remain neutral. In

\footnotetext{
167 "Die Angst der Europaer vor Europa," Süddeutsche Zeitung, December 9, 2000. German: Am "nationalistischsten" gebärden sich natürlich die Briten, die zu 67 Prozent keinen Souveränitätsverzicht zu Gunsten der EU leisten wollen.

168 "Salad Nicoise," Süddeutsche Zeitung, December 12, 2000. German: Großbritannien kann sich immer noch nicht entscheiden, ob es im künftigen Europa eine konstruktive Rolle spielen will. Wie kaum ein anderes EU-Mitglied haben die Briten in Nizza hartnäckig ihre Vetorechte verteidigt.
} 
terms of qualifying negativity in German press coverage of Britain, we cannot say that negativity or positivity is always subdued, as we have seen examples where this is not the case, although we can still say this is a general truth. On the level of individual newspapers, we have seen that there is significant difference between the findings for the weeklies for each focal point, and while the three broadsheet dailies tend to be consistent in their degree of negativity, the positivity fluctuates. Newspapers such as Der Spiegel and the Süddeutsche Zeitung that were found to use stereotypes in the test case were also found to continue this practice within an EU context. A recurring theme shared by most newspapers within both EU focal points was that of Britain as a laggard or inhibitor of European integration, suggesting that this is a popular image of Britain within this context. In a related point, we have seen that most newspapers portrayed Britain negatively when it acted in anti-EU ways, although on the other hand pro-EU initiatives by Britain were not always seen as positive. Nonetheless, it seems evident that the proEU position of German newspapers does generally affect their reporting on Britain within the integration process.

\section{Chapter Conclusions}

The findings within the German section allow for some interesting comparisons with the findings from the British section. First of all, the inconsistent attitudes in the German press contrasts with those of the British; we previously saw that that British press coverage of Germany was remarkably consistent across both EU focal point as well as in the test case, and that in almost all cases, non-neutral coverage was more negative than positive. This strengthens the arguments advanced by others that British press attitudes 
regarding Germany are generally negative regardless of context, while further allowing us to say that the same is not true of Germany, as we have seen that there is a willingness within some newspapers to treat Britain more positively within an EU context. However, despite its capacity for positive treatment and variation in attitudes, we can see by now that German press coverage can be just as negative towards Britain as British press coverage can be towards it. Within the Nice focal point, for example, the German press ran a higher percentage of combined negative articles (21\%) than the British (19\%). This negativity was expressed in different terms, of course, but it is nonetheless an important finding, as the scholarship so far tends only to comment on British negativity towards Germany.

Another finding that contrasts with those from the British section regards degrees of negativity. We have seen that while attitudes in the British press are most often neutral-positive or neutral-negative rather than pure positive or negative, and therefore relatively subdued, this is not a consistent finding in the German press. In terms of similarities, the broadsheet dailies from each country were found to remain consistent in their attitudes relative to each other over time, while the weeklies and tabloids tended to fluctuate significantly.

More generally, we can posit that the view that a newspaper takes on European integration does affect its portrayal of the other country in the process, although there is a clearer trend towards this in the German press. We have seen that Europhile German papers consistently portray Britain negatively when it acts in its own interests rather than those of Europe, and some portray it positively in the opposite case. On the other hand, the British Eurosceptic Daily Mail has been shown to report less negatively on Germany 
within an EU context, while the Eurosceptic Times reports more negatively, while trends among the Europhile British papers are hard to ascertain at this time.

As one final point, we have also seen by comparing the number of relevant articles run in the press of each country that Britain has a greater interest in Germany within an EU context than Germany has in Britain. Recall that this was hypothesized in the introduction and also found to be true for the test case. This finding has implications for British identity, which will be examined in the concluding chapter, although before this can happen, the findings so far will be tested against the findings from one final EU focal point, which concerns the EU Draft Constitution. 


\section{Chapter 3: Anglo-German Press Attitudes and the Treaty Establishing a Constitution for Europe}

We may now move into the final chapter of this thesis, which concerns AngloGerman press attitudes and the Treaty Establishing a Constitution for Europe, which is commonly called the Constitutional Treaty (CT) or European Constitution. The findings in this chapter will be compared against those of the previous chapters, and particularly the one concerning press attitudes during the Amsterdam and Nice focal points. This will allow us to confirm or refute hypotheses that have been made so far, and provide us with some solid conclusions about Anglo-German press attitudes in the field of European integration. The time periods that make up this final focal point are June 2004 and MayJune 2005. June 2004 is the month which saw the final version of the draft treaty emerge, and May-June 2005 focus primarily on the rejection of the constitution by France, although these two months also contain several other relevant occurrences, including the treaty's ratification by Germany, its rejection by the Netherlands, and the postponing of a referendum which would decide the issue in Britain.

\section{Background Information}

\section{The Constitutional Process}

After the rather disappointing results of Amsterdam and Nice, which produced only minor changes to EU structure and have been described as " 3000 mile oil changes for an automobile with rapidly accumulating mileage," it was widely accepted that an overhaul was needed in order to address the general problems of the EU and particularly 
its perceived democratic deficit. ${ }^{169}$ In December 2001, it was decided that a Convention on the Future of the European Union would be established, and that this convention would produce a draft treaty for a European constitution that would tidy up and replace all existing treaties, establish the division of powers between EU bodies and national governments, increase democratic transparency and efficiency, and prepare the union for additional enlargement. $^{170}$

The convention met between February 2002 and July 2003, and during this time period, many different proposals for the form of this treaty were considered. Richard McAllister has observed that during these negotiations the British position concerning new or expanded areas of competence for the EU was generally intergovernmentalist, and stood in opposition to the desires of the majority of member states, including Germany, which desired increased political integration. ${ }^{171}$ Following the convention, two meetings of the European Council (in December 2003 and June 2004) produced a lengthy and contentious draft treaty that was nonetheless agreed to by all parties. The treaty was signed on 29 October 2004 by representatives from all 25 member states, and thereafter it went to each member state for individual ratification. ${ }^{172}$ As mentioned in previous chapters, many of the leftover ideas from Amsterdam and Nice were incorporated into this treaty.

Ratification could take the form of a public referendum or government vote, depending on the desires of individual governments and the laws of the country. Over the

\footnotetext{
${ }^{169}$ Richard McAllister, European Union: An Historical and Political Survey (New York: Routledge, 2010), 216.

${ }^{170}$ John McCormick, Understanding the European Union: A Concise Introduction (New York: Palgrave Macmillan, 2005), 76.

${ }_{171}$ McAllister, 225.

${ }^{172}$ McCormick, 76-77.
} 
course of the seven months following the signing of the treaty, it was ratified by various means in a number of EU member states including Germany, where it was passed by large margins in the Bundestag and Bundesrat respectively on May 12 and May 27, 2005. The success of the constitutional treaty was doubtful in Britain, where Tony Blair had nonetheless promised to take the question to the people. However, the British referendum never materialized, as France rejected the treaty in its own referendum on 29 May, followed by the Netherlands on June 1. This sparked a crisis within the European Union, with some member states insisting that the ratification process continue, while others argued that it was a lost cause. On 17 June, the European Council officially suspended the ratification process, calling for a "period of reflection". ${ }^{173}$ Although Luxembourg chose to hold its own symbolic referendum in July 2005, the attempt to create a constitution for Europe was defeated for the time being.

\section{Anglo-German Politics, 2001-2005}

Despite the cordial environment that existed between Britain and Germany during the Amsterdam and Nice summits, bilateral relations had begun to deteriorate as the new millennium progressed. At this time, the heads of government in each country were experiencing their own domestic problems, and disagreements between the two countries emerged in the field of foreign policy and European integration. As mentioned earlier, Blair's pro-European stance during the Amsterdam and Nice summits had increasingly put him at odds with British public opinion. After this period, it therefore became necessary for the Labour administration to refocus on its own country and the opinions of its citizens. Although he desired to participate in the single currency project, Blair was

\footnotetext{
${ }^{173}$ McAllister, xxviii.
} 
unable to win over his Finance Minister, Gordon Brown, and the economic policy of the former regime was therefore retained. As a result, Britain was not one of the $12 \mathrm{EU}$ member states which saw Euro coins and notes enter circulation in January 2002.

With Britain experiencing considerable growth while adhering to its own economic model, politicians such as Brown began to view continental models, particularly that of Germany, as outdated. ${ }^{174}$ Across the channel, it had become clear even before the Nice summit that Schröder was an unpopular leader, with criticism emerging even from within his own party, the SPD. ${ }^{175}$

Relations between Britain and Germany became particularly frosty during the 2003 invasion of Iraq. In March of this year, Britain under Blair joined its traditional ally, the United States, in its attack on the country. This move was vehemently opposed by both France and Germany, and particularly by Schröder, laying bare the inability of Europe to establish a common foreign policy, and bringing out the tensions between the so-called "new Europe" and "old Europe" that would remain contentious until long afterwards. ${ }^{176}$ It was at this time that the Convention on the Future of the European Union was taking place, and clashes took place here as well. There were disagreements between both countries regarding the process itself, which found wide support in Germany and heavy opposition in Britain. ${ }^{177}$ Although bilateral tensions would eventually ease with the changing of the German government in November $2005,{ }^{178}$ the political relations between

\footnotetext{
${ }^{174}$ Claudia Crawford, "The Relations Between Great Britain and Unified Germany," KAS International Reports 9 (2010): 101.

${ }^{175}$ Crawford, 100 .

${ }^{176}$ Crawford, 102.

177 Crawford, 102.

${ }^{178}$ Following the defeat of Schröder's SPD by Angela Merkel's CDU.
} 
Britain and Germany during the time period included in this focal point were, to quote Claudia Crawford, “at rock bottom."179

\section{Eye on Germany: British Press Coverage of the European Constitution}

\section{$\underline{\text { Newspaper Coverage and Interpretation Overall }}$}

The data for this chapter comes from 331 newspaper articles collected from the previously mentioned three months that make up the focal point. Readers will note that the quantity of relevant articles is several times greater than it was for both the Amsterdam and Nice focal points, which made use of 104 and 116 articles respectively. While it may be argued that this increased number could be a result of the inclusion of an additional month to the time period of this focal point (the focal points for both Amsterdam and Nice were made up of only two months), it is clear that the average number of articles per month is greater for the current focal point, thus indicating a greater interest in this aspect of the European integration project. This should come as no surprise, as it has been previously mentioned that Amsterdam and Nice amounted only to tinkerings with the structure of Europe, while the European constitution aimed for a more far-reaching overhaul. Figure 3.1 shows the breakdown of coding for all articles:

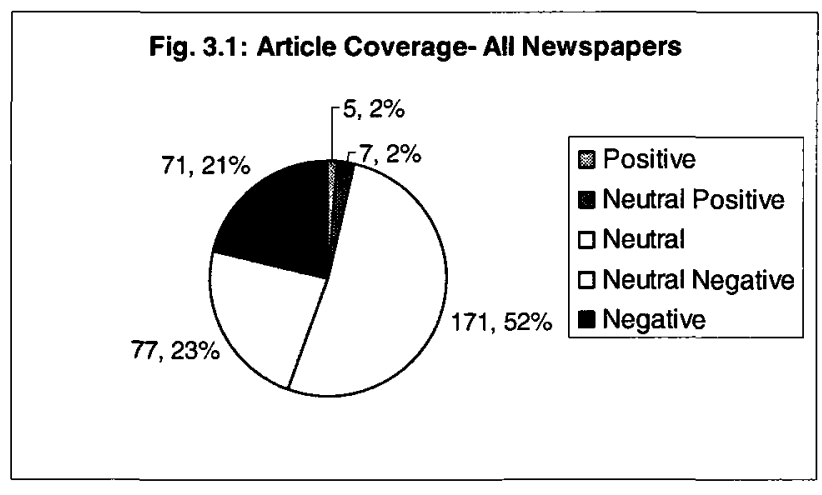

${ }^{179}$ Crawford, 102. 
It immediately becomes apparent that, although a majority of articles are coded as neutral (52\%), this focal point contains a high percentage of neutral-negative and pure negative articles, and their combined total rivals this count (44\%). It is also clear that there are very few articles receiving a positive or neutral-positive coding value, with the combined percentage totaling only $4 \%$. Figure 3.1 also makes it apparent that this focal point is significantly different from the three examined so far. Recall the similar graphs from previous chapters:

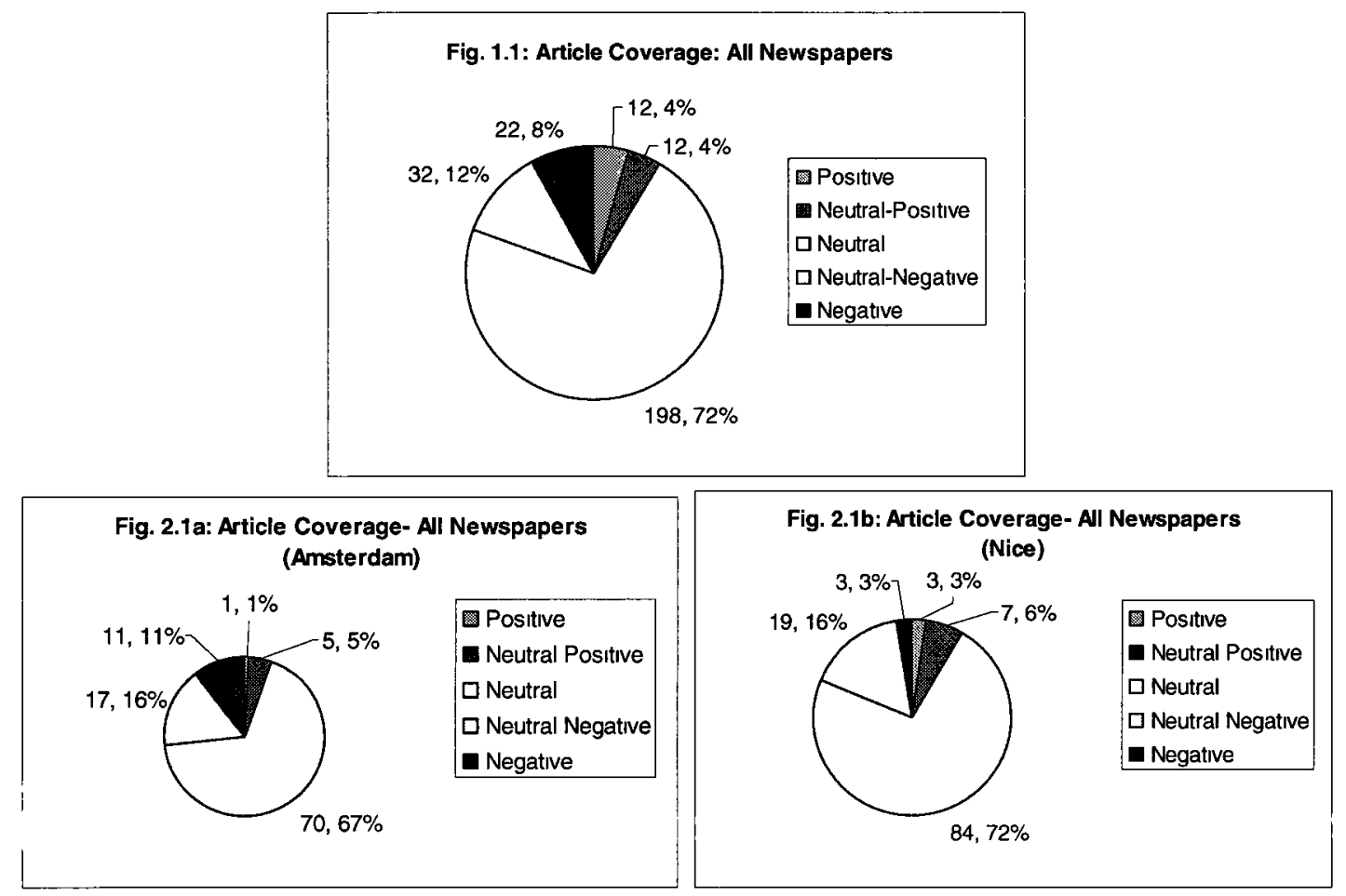

While the proportion of positive and neutral-positive articles is reasonably similar across all four focal points, ranging between $1-4 \%$ and $2-6 \%$ respectively, there is significantly less neutral coverage for the focal point concerning the EU constitution, and considerably more articles coded as either negative or neutral-negative. This comparison tells us several important things. First, these findings refute the hypothesis made in the previous chapter which guessed that the amount of positivity and negativity in the British press 
concerning Germany would be similar regardless of context. However, given that the combined values of positive and neutral-positive articles in all focal points is less than $10 \%$, we can now concretely say that:

The amount of positivity concerning Germany in the British press is similarly negligible regardless of the context.

We can also say that:

In general, the majority of British press coverage regarding Germany is neutral, and A significant percentage (19-44\%) of coverage tends to be either negative or neutralnegative in nature, with neutral-negative articles generally outweighing pure negative articles.

Overall, this means that the accepted view that the British press is negatively disposed towards Germany is broadly true, but requires some qualification. We have seen that this is only the case when neutral articles are discounted, and it is therefore more accurate to say that the press is more inclined to be negative than positive. Further, the use of a 5point coding scale has also shown us that negativity within the British press is most often subdued, rather than blatant. Both of these findings are important, as they provide a more nuanced understanding of what was previously a broad assumption.

Given that the primary focus of this thesis involves press attitudes in the field of European integration, we can also say that

There is no indication that coverage of Germany within an EU context has a consistent effect on British press attitudes. 
This is an interesting finding, and was not expected to be the case. Other general and specific conclusions can be drawn by moving on to an article breakdown by newspaper.
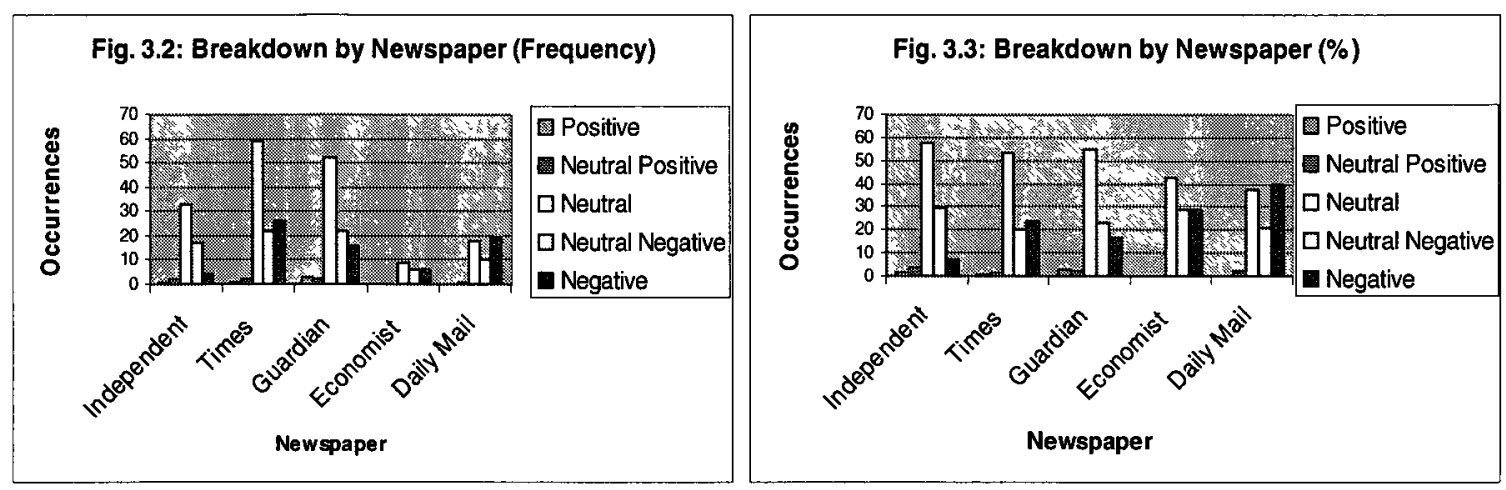

We can see that, with the exception of the Daily Mail, a majority of articles are coded as neutral for every newspaper. Beyond this, we can see that each newspaper contains a significant number of negative and a low number of positive articles, though each shows its own unique variation in proportion of pure and neutral-pure. This means that no two newspapers can be easily compared, although it can be said that the three daily broadsheets (Independent, Times, Guardian) are more similar to each other than to the weekly Economist and tabloid Daily Mail, for which the reverse is also true.

Once again, a comparison with earlier findings highlights the difference between this focal point and the previous ones.

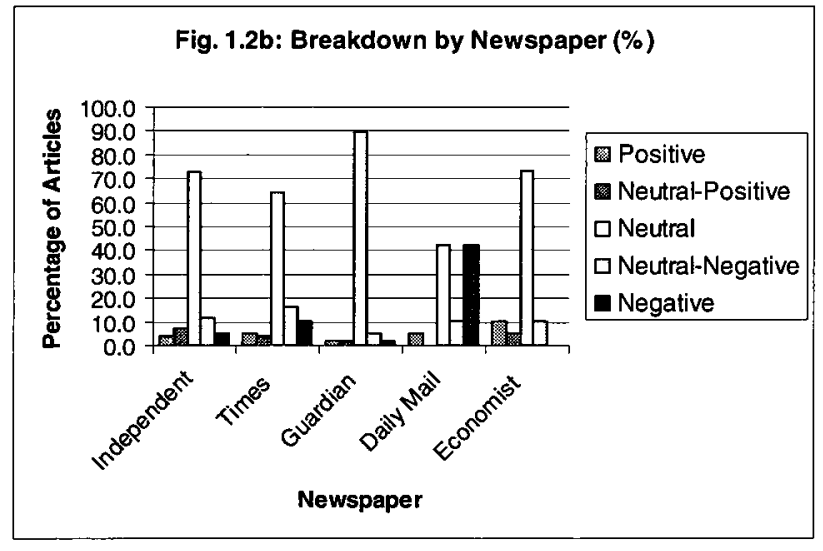



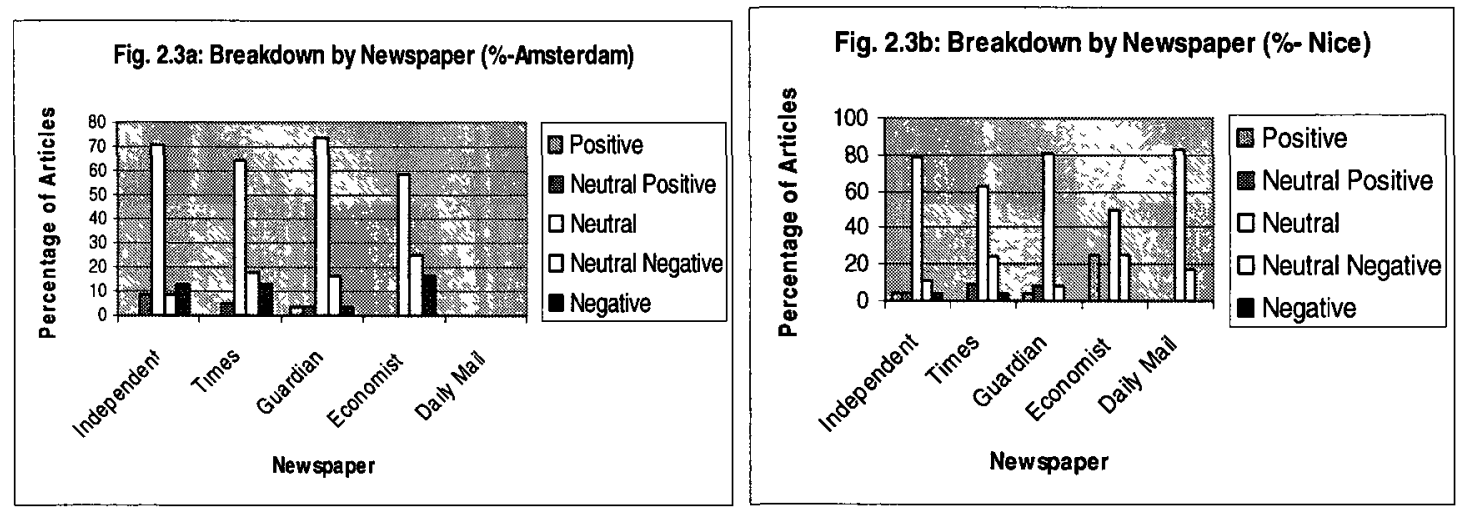

We can observe that the pure negatives for this focal point are higher than has been the previous norm, with three of five newspapers containing pure negative counts that are equal or greater to its neutral-negative count. Thus, we cannot say that negativity towards Germany in individual newspaper coverage is always more subdued than blatant (although this is a general truth for the British press as a whole), as coverage for this focal point has a tendency to be more blatant. In fact, this focal point is by far the most negative of the four contained in this thesis, with every newspaper displaying more negativity than has previously been the case. Combining negative and neutral-negative coverage, we find that even the most relatively positive newspaper (the Independent) contains $35 \%$ negative coverage, with the Times and Guardian higher than that, and both weeklies even containing a majority of negative coverage. Why this might be the case is considered in the conclusion of this thesis.

Additionally, the findings here have bucked the trend of relative negativity that had been found to exist between the three broadsheets. Whereas for the previous three focal points the order of descending negativity ran Times, Independent, Guardian, for this focal point it runs Times, Guardian, Independent. Admittedly, the difference between the Guardian and Independent is not great, and we may state as a final conclusion that: 
The relative, descending negativity displayed towards Germany by the Times, Independent, and Guardian, in any context, is remarkably consistent.

Furthermore, to provide a more nuanced understanding of the general conclusions above, the conclusions that can be drawn from these graphs for individual newspapers both within and outside of an EU context are as follows:

The British broadsheets, the Times, Independent and Guardian, consistently run a majority of articles coded as neutral when discussing Germany.

When discussing Germany, the Independent, Times, and Daily Mail consistently run more negative articles than positive, and the same is generally true of the Guardian, which did the same in 3 of 4 cases.

The Economist does not have set attitudes towards Germany.

Individual Trends and Themes

As has been the case in previous chapters, a list of common emphases appearing in the British press during the time period for this focal point has been created, in order to assist us in examining image construction as it relates to Germany. We have seen many of these themes previously in the focal points for Amsterdam and Nice, and an examination of their occurrences during the EU Constitution focal point will make differences and similarities obvious. There are a total of five emphases, and they are as follows:

1) References to the "Franco-German axis," motor, or mentions of France and Germany as a pair, or within the same sentence. 
2) The use of militaristic language when discussing Germany, portraying Germany as a bully, or referencing the Nazis or Second World War.

3) The characterization of Germany as "federalist" or otherwise pro-integration in the context of the EU.

4) Germany as an opponent of Britain or British desires, or Germany as otherwise representing an entity that is contrasted with Britain.

5) Economic references.

As before, the frequency with which a particular newspaper uses a given theme and in what light it is presented will allow us to gauge the concerns of a newspaper with regards to Germany in the European integration context.

Recall that the coverage of Germany within the Daily Mail was found to be considerably different between the test case and the Nice focal point, with the former being unambiguously negative and the latter highly neutral, and that this led us to hypothesize that the newspaper might be willing to view Germany less negatively within an EU context. With this in mind, the findings from this focal point are once again striking:

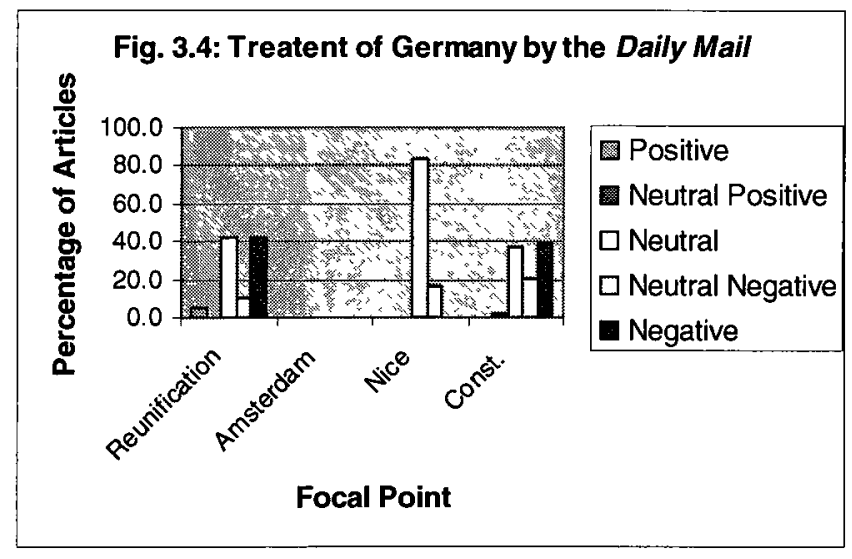


Figure 3.4 shows us that attitudes towards Germany from the EU Constitution focal point are remarkably similar to those displayed during German Reunification, with the Nice focal point appearing to be some sort of anomaly. Proportionally, the Daily Mail has once again become the most unambiguously negative newspaper of the five under examination, displaying the lowest neutrality count, along with very few positive articles and the highest number that are purely negative. There is even a recurrence of Nazi imagery and the theme of German militarism (examined later), which was present during coverage of the test case. Figures 3.5a-3.5c show the trend lines for the current focal point, which fluctuate between neutral and varying degrees of negative.
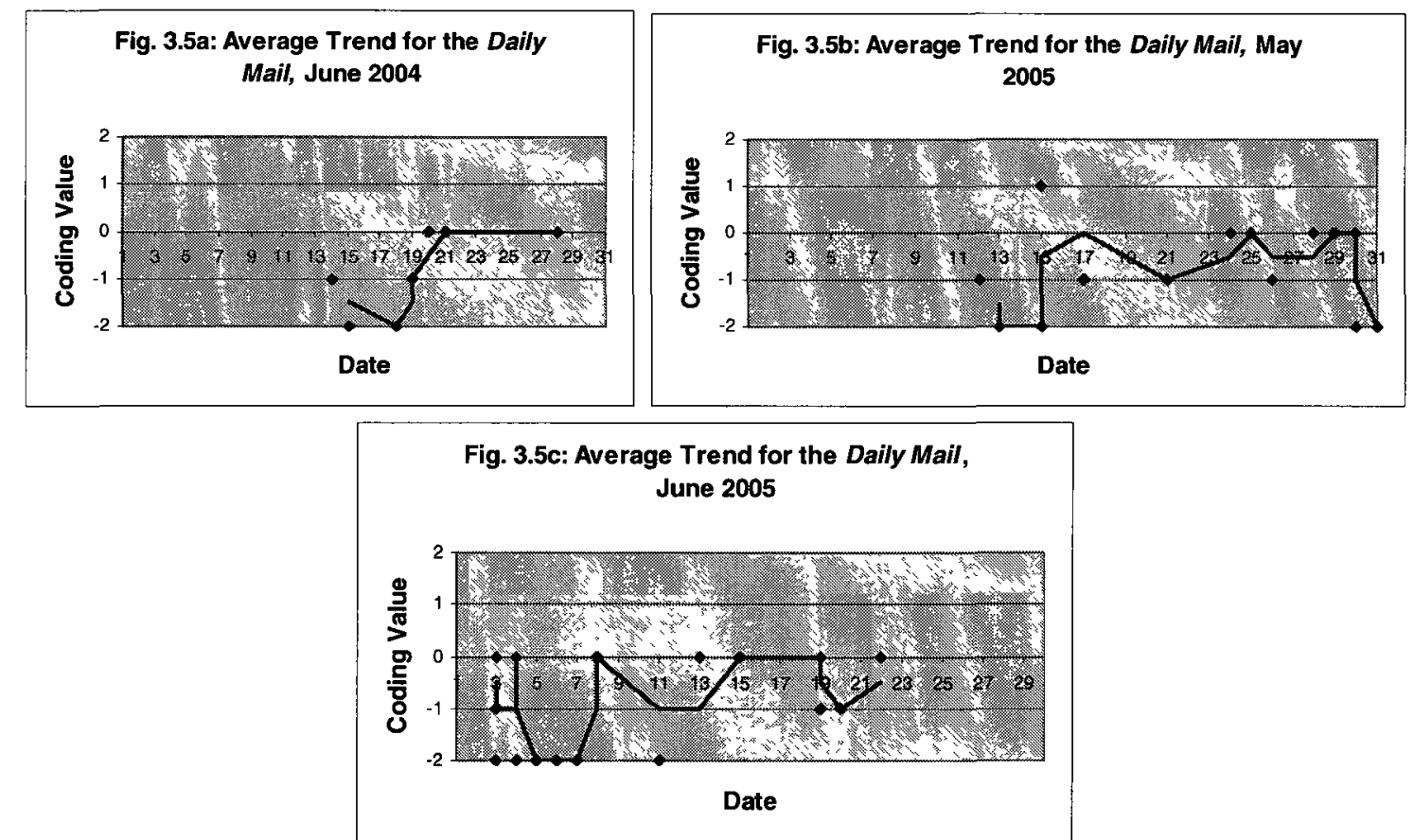

These findings disprove our earlier hypothesis and allows us only to say that the Daily Mail has the capacity to treat Germany in an overly negative way both within and outside of the context of European integration, although attitudes displayed within an EU context can be varied. Figure 3.6 shows the breakdown of common emphases for the newspaper: 


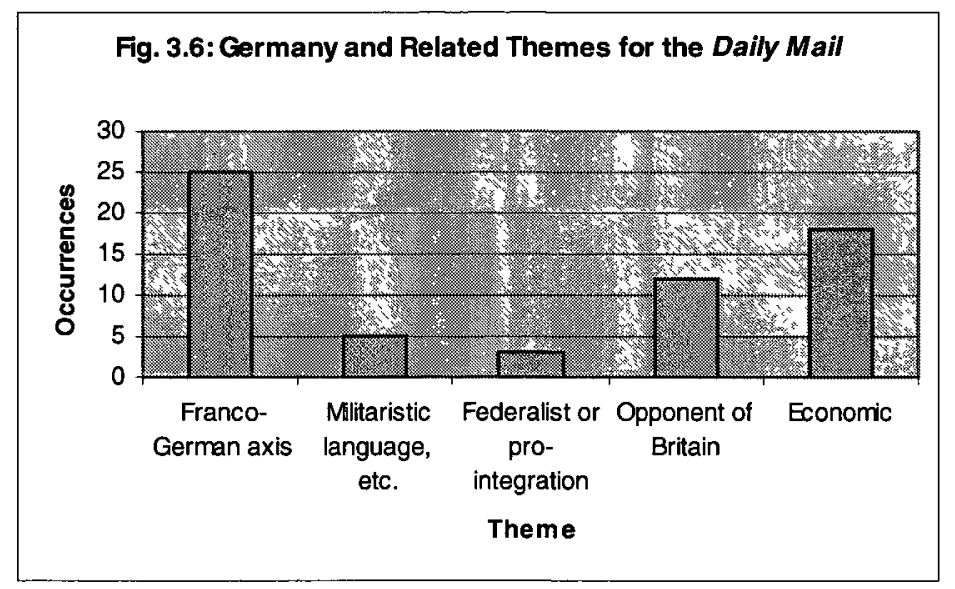

We can see that emphasis on the Franco-German partnership remains high, as was the case for Nice, and that articles concerning economics or that represent Germany as an opponent of Britain score high as well.

Turning to an examination of individual articles, we find that articles coded as neutral were engaged in passively relaying the news of the moment, with no particular importance assigned to any one thing. Articles from June 2004 contained references to Germany and its actions the negotiation process, while those from May-June 2005 covered such things as the ratification of the constitutional treaty by Germany, Schröder's efforts to save the constitution following the French "non," and rumours that followed of Germany leaving the euro area. No pure positive articles were present, and only one neutral-positive existed, and this did not mention anything positive in the present, but rather discussed the past success of the German economic miracle.

A total of 10 articles from this focal point were coded as neutral-negative, and these tended to either comment on Germany's dire economic situation, or to make unflattering or vaguely threatening comments about the Franco-German partnership:

Now, however, the French and Dutch referendums have presented [Blair] with a golden opportunity for a palace revolution, to assemble a rival power base to knock France and Germany off their European perch -- and replace the creaking 
EU economy with a British- style market model, on the basis that by their 'no' votes the peoples of Europe have sent a clear message that the old order has to change. $^{180}$

This rather sinister portrayal of the Franco-German partnership and references to its power is consistent with the neutral-negative coverage of the Daily Mail from the Nice focal point, and is very likely due to the Eurosceptic views of the newspaper. The idea that Britain can provide better economic alternatives offers further proof of this.

As previously mentioned, the Daily Mail is the most proportionally negative newspaper in this focal point, with about $40 \%$ of articles (there were 17 in total) being coded as pure negative. The same themes that appeared in neutral-negative articles appear more strongly phrased here, with negative economic references continuing to be popular, and there is also a definite and sustained attempt to portray France and Germany as enemies or opponents of Britain:

TONY BLAIR was struggling to hang on to crucial concessions last night in a bitter struggle over the new EU constitution. France and Germany insisted that the allowances given to Britain had gone too far...France was not alone - German Chancellor Gerhard Schröder and Belgian Prime Minister Guy Verhofstadt joined the anti-British assault over tax...As the summit quickly turned sour, European officials declared they were 'not surprised' at the Franco- German led backlash, which set the scene for a split between old Europe - led by Paris and Berlin - and new Europe, led by Britain and the ten nations that joined the community on May $1^{181}$

As mentioned earlier, there was a resurgence of Nazi imagery through the mention of "the deflation of the early Thirties which brought Hitler to power," 182 although this is linked to Germany's economic problems and by itself is not overly offensive. However,

\footnotetext{
180 "The Greatest Political Cross-Dresser of All Time has Once Again Stolen his Opponent's Clothes," Daily Mail, June 20, 2005.

181 "You've gone too far," Daily Mail, June 18, 2004.

182 "How the Euro unites nations in disaster," Mail on Sunday, June 5, 2005.
} 
while Nazi imagery did not itself appear in a more blatant form, the theme of German militarism did:

The EU is popular here because it pays, and because it leaves the French alone. It is also beloved because the French have no Channel to divide them from Germany, that clanking, unpredictable monster of blood and iron that sits hugely just over their eastern horizon...So it is more than surprising to find that France is now thinking seriously of wrecking the planned new European Constitution. ${ }^{183}$

To be fair, these references only occurred in a minimum of articles, but what is important is that fact that they re-emerged at all. It does not seem to be a stretch to imagine that this negativity, (particularly with its references to the "old" and "new" Europe, as seen earlier), to some extent reflects the poor diplomatic relations between Britain and Germany at the time. In fact, referring back to Figure 3.4, it would seem that negative coverage in the Daily Mail fluctuates according to the tone of political relations. This would make sense given the newspaper's status as a tabloid, but unfortunately, this case cannot be proven concretely here.

What can be said about the Daily Mail overall is that the amount of negativity which is manifested towards Germany is not affected by a particular topic. This is evidenced both by the similarities displayed by the attitudes from the Reunification and EU constitution focal points, and by the differences that the latter point shares with the Nice focal point. Within an EU context, we have seen that the newspaper consistently portrays the Franco-German partnership as a sinister force within Europe that often acts against the wishes of Britain. Themes such as German power and militarism also appear regardless of context. These findings have important implications regarding British image construction as well as identity, which is discussed in the conclusion.

183 “Peter Hitchens reports from Paris..." Mail on Sunday, May 15, 2005. 
Previously, attitudes in the Times have been shown to be reasonably similar across all focal points, and while coverage from the current focal point is somewhat different from that of previous cases, it can still be said to possess reasonable similarities as well.

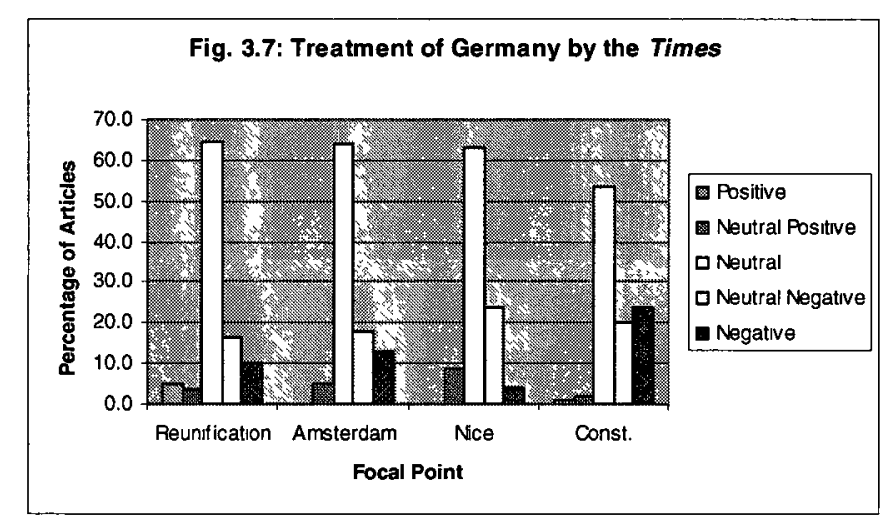

The major difference between this focal point and previous ones is that here pure negative articles outweigh neutral-negatives, which is not typical for the quality papers in general and the Times in particular. However, the proportion of neutral-negative articles remains similar to previous focal points, and neutrals still account for a majority of coverage, allowing us to claim some degree of consistency. We can also say at this time that the Times shows a definite tendency to report more negatively on Germany within an EU context than outside of it. This is evidenced by the fact that the three EU focal points individually contain a higher combined negative count than the test case, which in turn contains a higher combined positive count than any one of the EU focal points. The consistency here is almost certainly due to the fact that the Times is a Eurosceptic publication, and the fact that coverage does not mirror the state of diplomatic relations between Britain and Germany, as the Daily Mail appears to do, may point to the difference between a Eurosceptic tabloid and a Eurosceptic broadsheet. Figures 3.7a-3.7c show the trend line for the Times: 

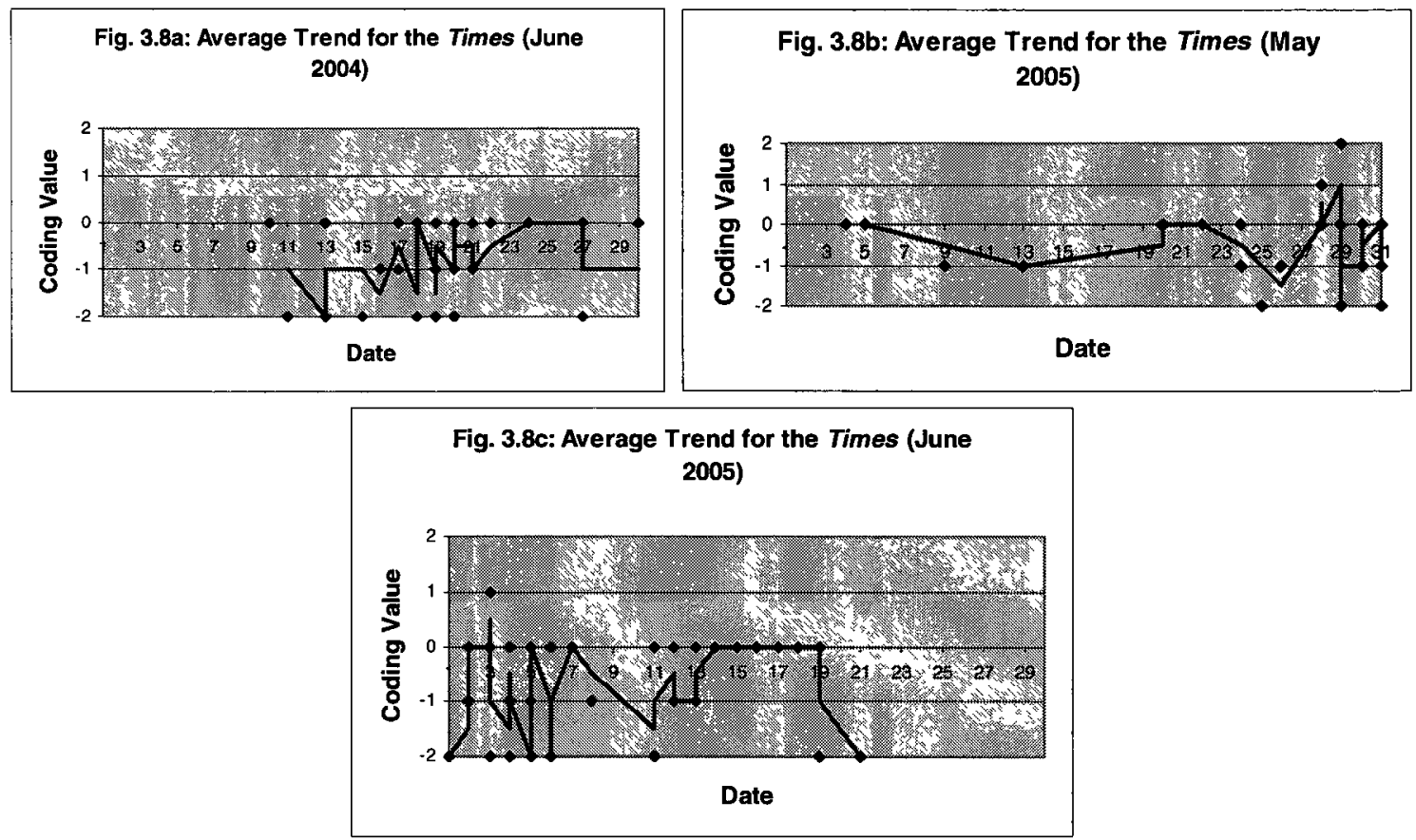

It is clear from these graphs that Times coverage of Germany is generally negative, and that the most negative articles line up almost exactly with the dates of major events in the timeline of the European Constitution. We can see that at other times coverage is generally more neutral, which lends further strength to the argument that the Times is more negatively disposed towards Germany within an EU context.

Referring to this list of common emphases, the Times scores as follows:

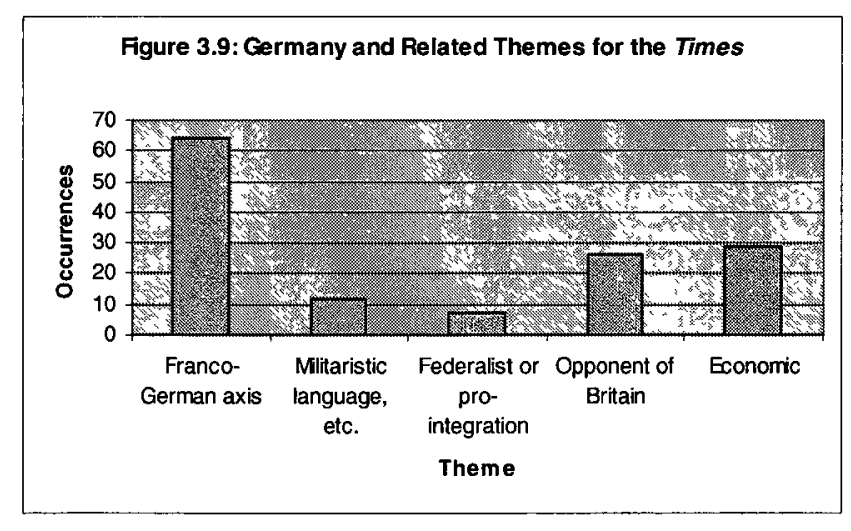

It can be seen here that the Times shares similarly proportional emphases with the Daily Mail, as both devote the most consideration to the Franco-German relationship, followed 
by articles focusing on economics or where Germany is an opponent of Britain. Referring back to the Amsterdam and Nice focal points, we find that there is a consistently high mention of the Franco-German partnership, although other themes do not necessarily correlate. Economics were featured at Amsterdam but not at Nice, and the same is true of articles portraying Germany as an opponent.

In individual articles, mention of France in conjunction with Germany featured frequently in articles coded as neutral, although these were not otherwise marked by common features, the Times tending mostly towards passive reporting on events concerning Germany (and France) as they occurred. Like the Daily Mail, the Times ran a low number of positive and neutral-positive articles, although these did exist for this focal point. One pure positive article appeared on 29 May 2005, and commented on the strong state of German exports. ${ }^{184}$ Two neutral-positive articles also appeared, but were not linked by a common theme. One contained a secondhand report on how the constitution (a Franco-German initiative) would help to strengthen and democratize Europe, and the other suggested that a change of government in Germany might be positive, as it would weaken France. This last article is important, as it suggests that Britain's real European enemy is France, not Germany, which will be discussed later.

As mentioned earlier, the Times ran a significant number of neutral-negative and pure negative articles (22 and 26 respectively). Almost every article coded as neutralnegative discussed France and Germany together, painting them as a vaguely sinister force, often standing against Britain.

TONY BLAIR is facing a Franco- German ambush this week over Britain's Pounds 3 billion annual European Union budget rebate after signalling his determination to kill off the European constitution...The Franco-German meeting

184 "Why a French no could boost your portfolio," Sunday Times, May 29, 2005. 
was being watched closely in Downing Street for signs of any plans to resurrect the notion of an "inner core" of fast-track member states, which might exclude Britain . ${ }^{185}$

Economics was also a common theme in these articles:

The British Government had always championed the enlargement of the EU because it believed that new Europe would prove a solid ally in the battle against the Franco-German push for more political integration, and would share a freemarket vision of independent nation states. ${ }^{186}$

Articles coded as pure negative carried the same themes in stronger terms, often

portraying France and Germany as bullies, while also commenting on the dismal state of their economies and suggesting that Britain could provide a better alternative.

[Chirac and Schröder] were determined to show that the "Franco-German couple" offered the best lifeline for Europe as it struggled to overcome the double rejection of the constitution that they had for years been promoting...however, it seemed they had lost the battle as other countries, tired of being dictated to by economically stagnant behemoths at Europe's core, looked instead to guidance from Britain...Complaints have been multiplying about how the Franco-German duo used to lord it over the others and brazenly shift the goal posts when it suited them, as they did by defying the growth and stability pact's cap on budget deficits...After their experience under the Soviet yoke, these countries were wary of Franco-German domination. Even better, they were sympathetic to the economic liberalism upheld by Britain.. ${ }^{187}$

Traditionally, France and Germany agree a way forward that is then imposed on all other countries but Britain is challenging that arrangement, hoping that it has enough allies in the enlarged EU to ensure the first significant defeat for the combine in 40 years. ${ }^{188}$

In concluding our examination of the Times, a number of things can be said. First, as we saw earlier, there is ample evidence to suggest that the newspaper is more negatively disposed towards Germany within an EU context, which is in line with its Eurosceptic nature. Second, we have seen that general themes of economics and power are common

\footnotetext{
185 "Blair faces EU budget ambush," Sunday Times, June 5, 2005.

186 "Shifting loyalties in Brussels highlight the new shape of Europe: EU summit," Times, June 19, 2004.

187 "Old Europe dithers while Blair plots; Euro crisis," Sunday Times, June 5, 2005.

188 "Battle lines drawn up as leaders get ready for a war over EU," Times, June 6, 2005.
} 
when discussing Germany, and this does not depend on the topic being examined. Third, it is apparent that the Times is extremely interested in the Franco-German relationship, high coverage of which appears in all three EU focal points, and it is also clear that it sees this bloc as an opponent and portrays it in negative terms.

It is important to note on this last point that it seems that what the Times sees as more negative is the combination of France and Germany, not Germany alone. This coverage from the Times in this thesis provides ample evidence that Germany is viewed in less negative terms when France is not a part of the equation. Recall that for the Amsterdam and Constitution focal points, the Times ran a significant number of articles portraying Germany as an opponent and also portrayed the Franco-German relationship in menacing terms. This last point was also true for the Irish rejection portion of the Nice focal point. These themes coincided with periods of good relations between France and Germany. In the only time period where this was not the case, during the Franco-German quarrel concerning voting weights at the Nice summit, we saw that the Times ran a series of articles portraying Germany positively as an ally and was silent on the Franco-German menace. It is also perhaps important to note at this time that the Nice focal point also contained far fewer articles portraying Germany in purely negative terms. Why the combination of France and Germany would evoke more negativity than Germany by itself would is uncertain, perhaps suggesting a more negative view of France, but I argue in the conclusion that is because of the old notion of the balance of power.

As with the Times, Independent coverage from the EU Constitution focal point displays both differences and similarities with previous findings. 


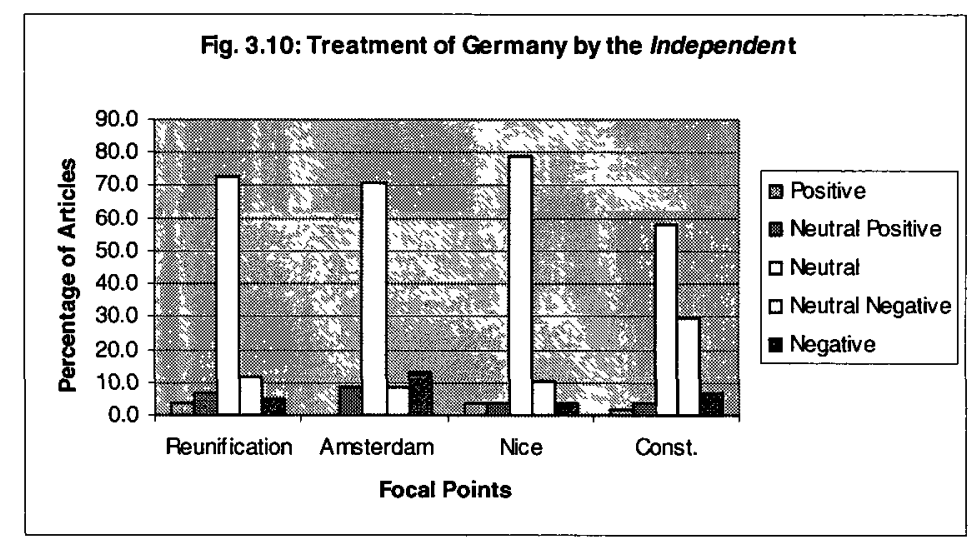

The most notable difference is in the increased neutral-negative count, which corresponds to the decrease in the number of neutral articles. Despite this, however, neutral articles still account for a majority of Independent coverage, and the proportions of positive, neutral-positive, and pure negative articles remains comparable to previous focal points. Very little can be said at this point for the Independent by way of overall conclusions, except that there is no indication that an EU context has any effect on the amount of negativity that the newspaper displays towards Germany.

The Independent displays an interesting trend line, though this is largely because it is the only newspaper where the trend remains positive for any amount of time.
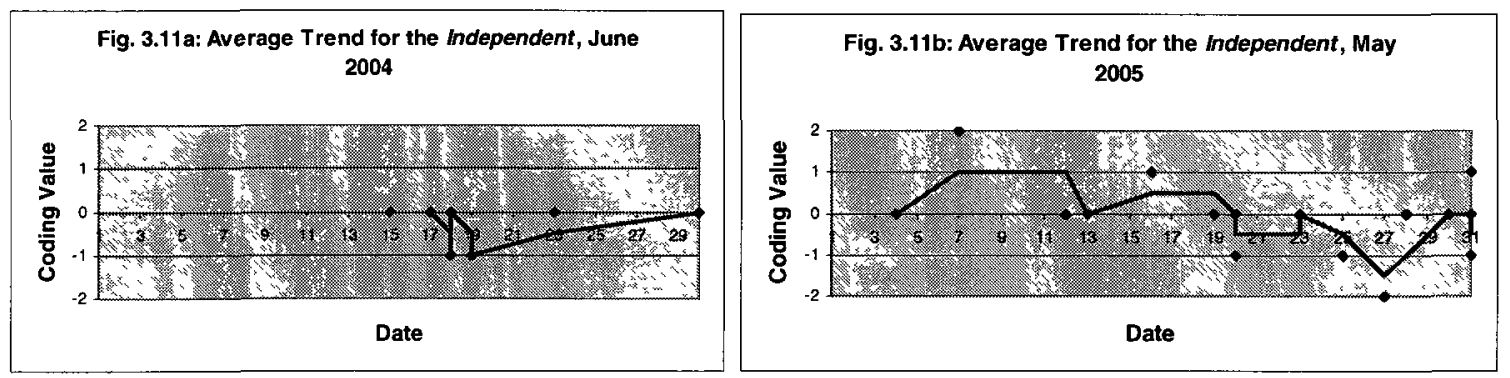


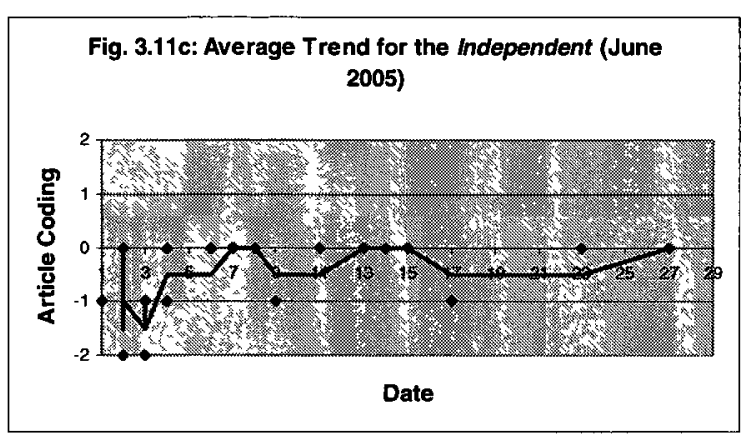

As with the Times, there is clearly more negative coverage of Germany surrounding important dates in the history of the European Constitution, and this becomes more neutral and even positive at other times:

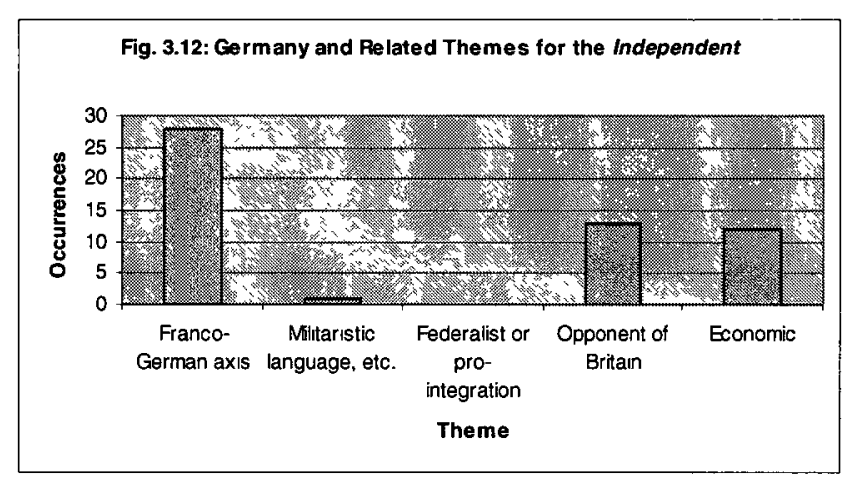

Figure 3.11 shows the breakdown of common themes for the Independent, and we can see from this that the newspaper mirrors the Daily Mail and Times by placing similar emphasis on the Franco-German relationship, Germany as an opponent, and economics. Recalling coverage from the Amsterdam and Nice focal points, we see once again that this newspaper is consistent in its portrayal of France and Germany together, but that little else correlates.

Articles coded as neutral for this focal point followed the standard set by other newspapers thus far and had no particular theme. In positive and neutral-positive articles, where 1 and 2 articles were run respectively, the focus was economic, with the former stating, "Germany, moreover, is well-placed to benefit from its strong trading ties with 
China, which is expected to power the global economy over the next 10 years." ${ }^{189}$ In terms of the remaining neutral-positive articles, one discussed a semi-positive socioeconomic idea originating in Germany, and the other commented favourably on the German economy. These bear little comparison to the positive articles of previous focal points.

In terms of neutral-negative articles, the Independent ran a relatively high number (17), especially compared to the number of pure negatives (4). The neutral negatives followed the tendency of British newspapers thus far by frequently pairing France and Germany together. Recalling that previous Independent complaints about France and Germany tended to come more from their perceived damaging of the European project or un-European actions than from any sinister motives, and it becomes clear that Independent attitudes had shifted slightly to include the latter to a certain extent. On this point, there were many articles that discuss fears of Franco-German actions:

M. de Villepin said France's commitment to European integration remained "unshaken" by the "no" vote on the proposed EU constitution 10 days ago. He added, however, that France would look for ways to establish a "union" with Germany on an unspecified range of policies' reinforcing fears that Paris and Bonn may now seek to create an "inner core" of EU countries. ${ }^{190}$

Some of these included notions of relational power which had been a previous concern for the newspaper. One commented that many Dutch no-voters were "motivated by fears the constitution would increase the powers of the big EU states, notably France and Germany, at the expense of the smaller nations."191 Annoyance regarding the actions of France and Germany and their consequences for Europe were also mentioned, as has previously been the case.

\footnotetext{
189 "Rich pickings for investors happy to channel-hop," Independent, May 7, 2005.

190 "PM promises to create new jobs after French reject constitution," Independent, June 9, 2005.

191 "Dutch sceptics set out to send unpopular constitution up in smoke," Independent, June 2, 2005.
} 
Of the four articles coded as pure negative, all focused on the dismal political and economic situation in Germany, mirroring to a certain extent the negative economicsfocus of articles from the Amsterdam focal point:

That [SPD] defeat, in turn, was precipitated by many factors: a malaise that set in as a result of the economic cost to the western half of the country from reunification; a decline in national morale reflecting Germany"s reduced economic clout within Europe and a flick of dissatisfaction over the government"s arrogance in not giving Germans a vote on the European constitution. ${ }^{192}$

In closing our consideration of the Independent, we can say that the newspaper is generally consistent in its attitudes towards Germany across focal point, as well as in the themes that emerge within an EU context. Unlike the Times, there is no indication that the Independent treats Germany more negatively within an EU context, nor are the themes within the EU focal points repeatedly consistent, although some continuity is present nonetheless. In terms of these themes, this newspaper compares more favourably with other newspapers within the same focal point than it does with itself across time.

It is interesting to note for coverage of the Guardian, that while it follows the usual broadsheet tendency of running more neutral-negative articles than pure negative, the pure negative count is nonetheless much higher for this focal point than it has been for any previous one, and is approximately five times greater than the negative coverage from Amsterdam, which was the next most negative

192 "The real reason for Old Europe's revolt," Independent, May 27, 2005. 


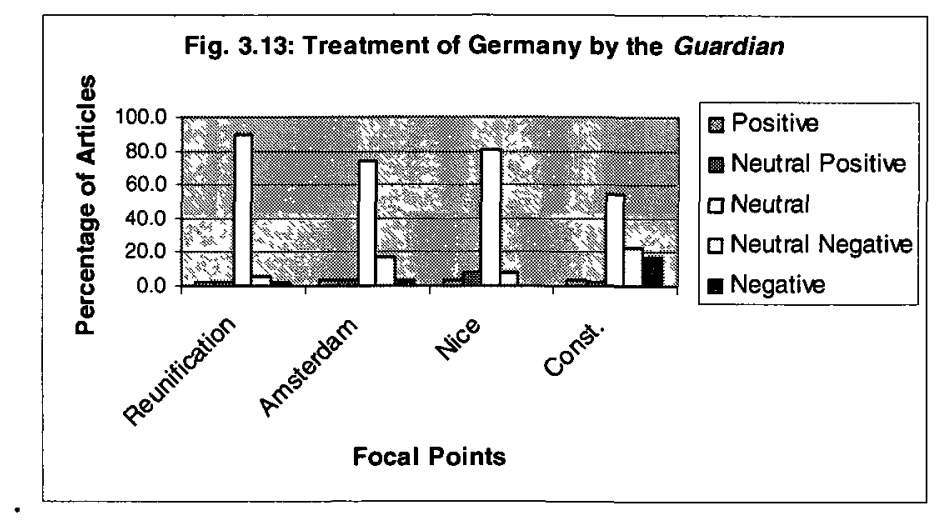

Neutral-negative articles are also significantly higher than in previous focal points, and the neutral count has declined significantly, although it still remains a majority. The proportion of positive and neutral-positive articles remains roughly the same. Like the Times, combined negative coverage for the Guardian is always greater within the EU focal points than it is in the test case, however, the same is also true of combined positive coverage. We cannot therefore say that the Guardian treats Germany more negatively within an EU context, or that its pro-Europe position affects its attitudes towards the country, but we can say that the newspaper is more opinionated than otherwise when it comes to this area. Examining the three EU focal points in Figure 3.12 reveals that coverage of Germany was more positive during the Nice focal point than it was for Amsterdam or the EU Constitution, which was also the case for the Times. Recalling that it was hypothesized in a previous chapter that this might be inversely related to the nature of Germany's partnership with France, and it remains to be seen to what degree attitudes in the Guardian will mirror those of the Times. 

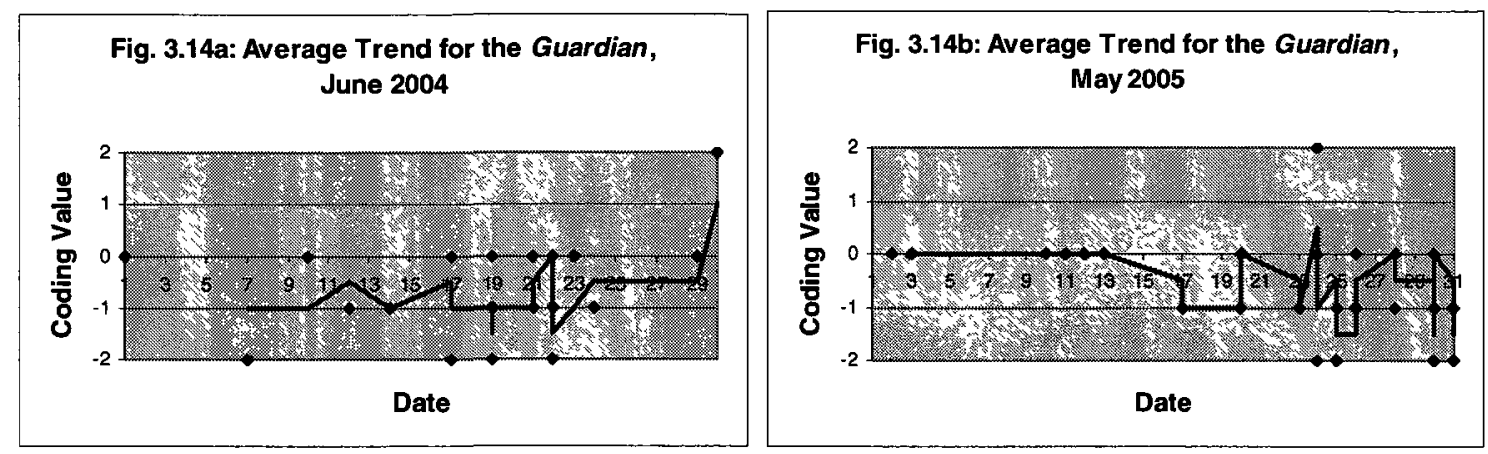

Fig. 3.14c: Average Trend for the Guardian, June 2005

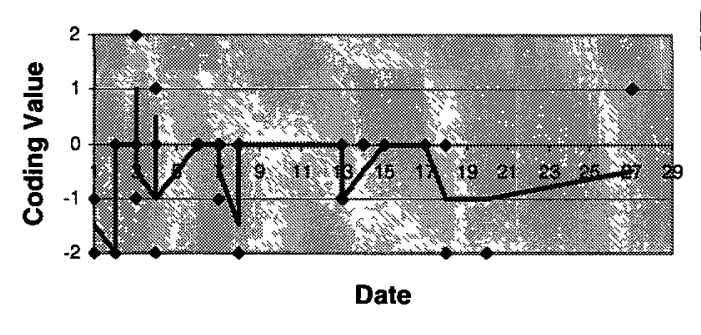

The trend lines for the Guardian show a regularly fluctuating negative-negative tendency that is generally unremarkable. In terms of common emphases, the Guardian is remarkably similar to all the newspapers examined so far, in that it assigns high importance to the Franco-German relationship, followed by economics and Germany as an opponent.

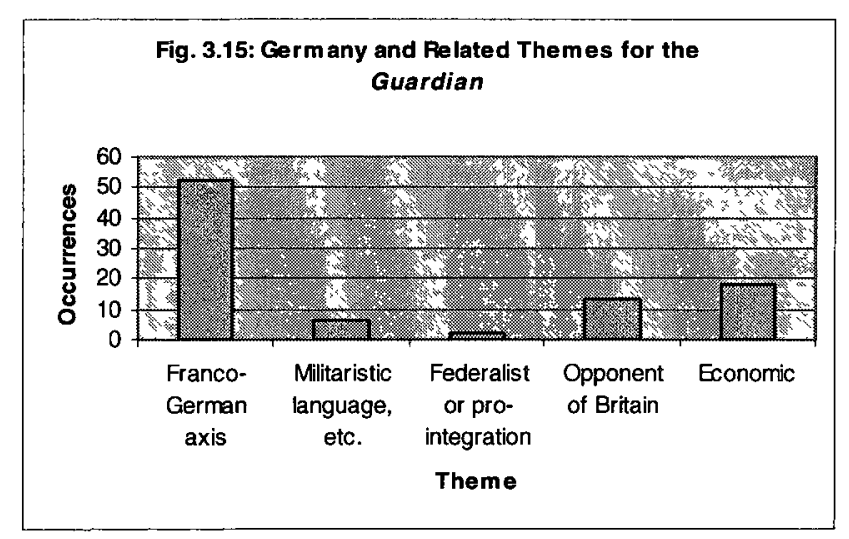

Neutral articles for the Guardian displayed the same tendencies as those of other newspapers, passively reporting on events as they occurred, with no real focus. In terms 
of articles coded as positive or neutral-positive, the newspaper ran 3 and 2 respectively.

The pure positive articles all focused on positive aspects of the German (and sometimes

French) economy, with one also complimenting the German populace as being "highly educated and highly skilled." ${ }^{193}$ The two neutral positives did not share a common theme; one was simply a reprinting of a Times article (mentioned earlier) discussing the benefits of a change in German government, and the other contained a second hand mention of the high quality of German technical education that might benefit all of Europe. ${ }^{194}$

The Guardian ran a high number of articles coded as neutral-negative (22) that discussed a variety of topics, including such things as German economics, political volatility, and general decline. However, as with previous newspapers, many of these did indeed portray France and Germany as a sinister or incompetent force:

It is a constitution now comprehensively rejected by the people of France and the people of the Netherlands. Yet the political dinosaurs at the helm in France and Germany and the army of Eurocrats whose careers depend on the gravy train act as though nothing at all has happened. ${ }^{195}$

In June 2004, there was also focus on the power of big states over the small, and France and Germany were mentioned here as well, sometimes in conjunction with other powers:

Under the leadership of Germany and France, smaller member states have grown increasingly concerned, with good reason, that ultimate EU power will reside in the Paris-Berlin-Brussels axis. ${ }^{196}$

The re-emergence of this theme for this focal point suggests that the previous hypothesis, which guessed that Guardian attitudes towards Germany are linked its role in the FrancoGerman partnership, is indeed accurate. Like the Times, it seems that the Guardian treats Germany more negatively when its relations with France are healthy. The theme of

\footnotetext{
193 "Germany and France are struggling with a new world: Martin Kettle," Guardian, May 25, 2005.

194 "Practical European who will need a strong constitution," Guardian, June 27, 2005.

195 "MPs warn Straw not to smuggle in treaty by back door: Future of Europe," Guardian, June 7, 2005.

196 "Washington Times Editorial, June 21," Guardian, June 22, 2004.
} 
France and Germany as bullies, treaty violators, and economic losers was dominant in the pure negative articles as well, lending further credit to this idea:

The idea of an integrationist Franco-German core emerging from the rubble seems fanciful: what do the two biggest and most underperforming economies in the eurozone have to offer by way of leadership? ${ }^{197}$

As the biggest per capita net contributors to the Brussels budget, [the Dutch] also feel bullied by the bigger countries and let down by the single currency, seen to have brought steep price rises while the currency's rulebook has been flouted with impunity by Germany and France. ${ }^{198}$

Some stereotyping and Nazi imagery also appeared in the purely negative articles,

although this was less common:

He ran through all the ways in which the EU would now control our lives. "New burdens on business and public services!" he shouted. "No!" replied Labour MPs, many of whom are deeply suspicious too, but will support Mr Blair for the time being. European legislation to bring in even more red tape! said Mr Howard. "No!" they roared back. German stormtroopers to seize young British girls from school and sell them into slavery in Namibia. "No!" shouted Labour MPs. I may have made the last bit up, but it does give the flavour. ${ }^{199}$

In concluding with our examination of the Guardian, we can say a number of things.

First, our findings suggest that, due to increased positive and negative coverage within the EU focal points, the Guardian is more interested in German activities than might otherwise be the case. Second, we have seen that there is a recurring tendency to portray Germany as a powerful and sinister entity within an EU context when it is allied with France, and third, like the Times, the Guardian is more inclined to view Germany in less negative terms when this is not the case. As mentioned earlier, possible reasons for this will be discussed in the conclusion.

\footnotetext{
197 "Comment \& Analysis: French referendum: Europe stunned," Guardian, May 30, 2005.

198 "Crushing defeat leaves EU vision in tatters: Massive rejection by Dutch voters likely to bury constitution," Guardian, June 2, 2005.

199 "Myth makers? Look who's tocking!" Guardian, June 22, 2004.
} 
Proportionally, coverage from the Economist for this focal point scores the second highest in both pure negative and neutral-negative articles, and it is moreover the only newspaper that lacks any amount of positive coverage.

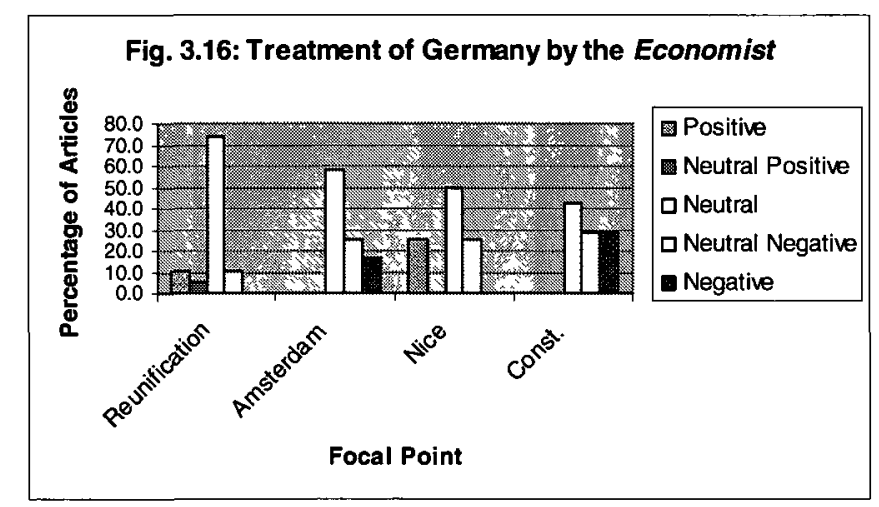

We can see that coverage from the EU Constitution focal point compares best to the Amsterdam focal point, and there is otherwise little continuity that is apparent. The other newspapers in this focal point have shown the same tendency exhibited here, that is, to display more negative attitudes towards Germany for the Amsterdam and EU

Constitution focal points than for Nice, and we have taken this to be related to Germany's relationship with France. For the Economist, it does not seem as likely to be the case, as there was little indication given in the coverage for either Amsterdam or Nice that this relationship was viewed negatively. What can be said of the Economist is that, like the Guardian, there seems to be an increased interest in German activities within the context of European integration, as the proportion of both positive and negative articles tends to be much higher for these focal points than the test case.

The number of articles run by the Economist during this focal point was relatively high (21) when compared to its coverage from other EU focal points (12 and 4), but this is still low when compared to other newspapers. Despite this, it has been possible to create partial trend lines for the three months of this focal point, displayed in Figures 
3.17a-c below. Figure 3.18 shows the breakdown of common themes for the Economist, and we can see at this point that, proportionally, all five British newspapers have been remarkably similar in what they choose to emphasize within this focal point.
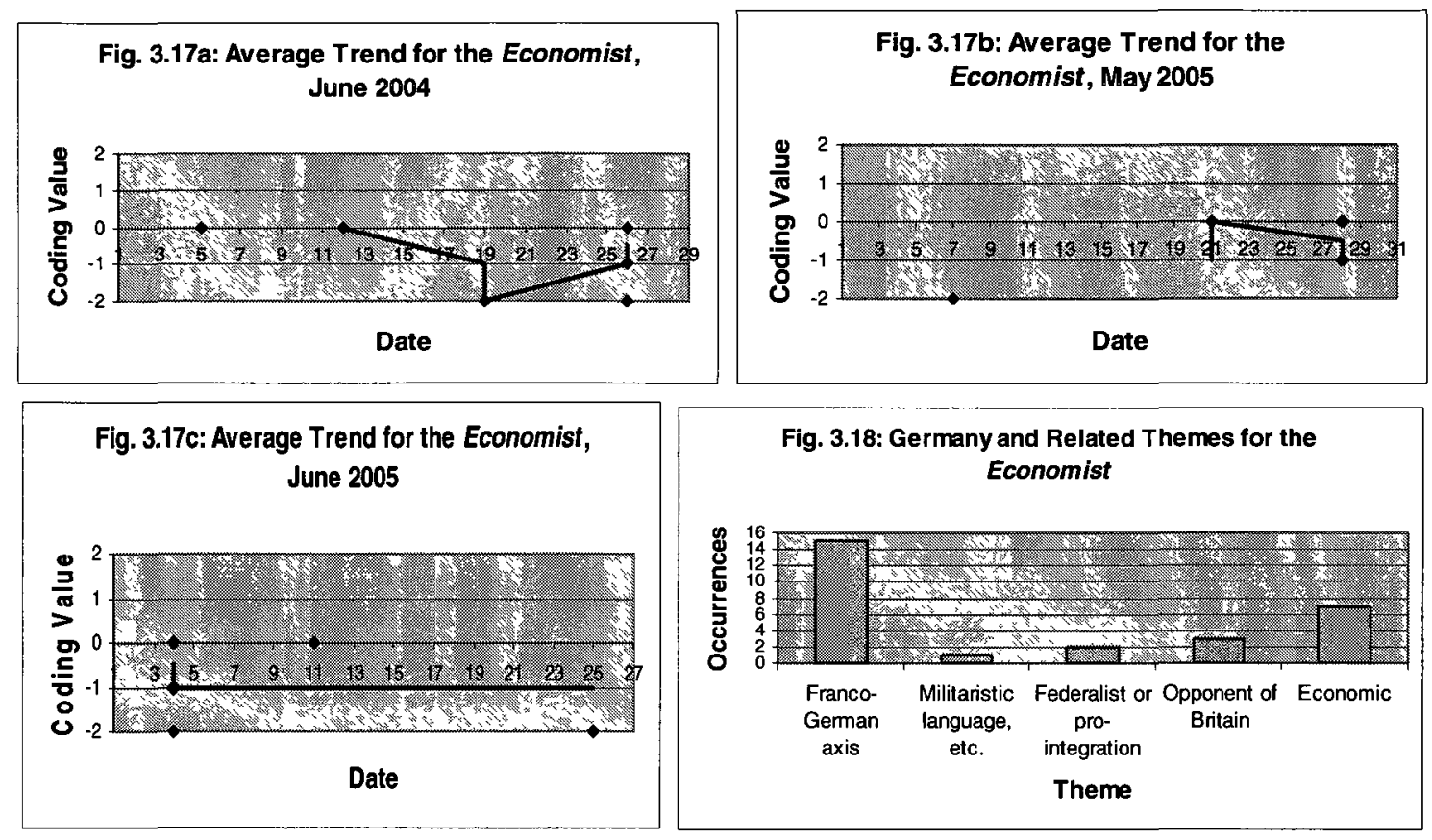

Unlike any other British newspaper in this focal point, the Economist does contain a common theme in its neutral coverage of Germany, which is that of France and Germany mentioned together. We have seen this theme previously emerge in negative coverage, but not as predominantly in neutral coverage. In June 2004, most neutral stories mused that the Franco-German engine might no longer be the force it once was:

If there is no deal on an EU constitution, France and Germany will doubtless fall back on each other to revive closer bilateral integration. But the historical postwar zeal combined with sheer hard work that have made the Franco-German couple endure so far can no longer be taken for granted. ${ }^{200}$

There was no clear theme for the articles run during the French rejection, although these continued to mention France and Germany together. This theme was carried into the

200 "Je t'aime, ich auch nicht- Franco-German relations," Economist, June 5, 2004. 
neutral-negative articles, which portrayed the power of the Franco-German couple as waning. One stated that "One unkind member of Mr Chirac's own party was quoted in Le Figaro this week likening the Chirac-Schröder partnership to one between the 'blind and the crippled'.,201

In these articles, there was also an indication that Franco-German desires were different from those of Britain, and there was a certain amount of triumphalism as well:

IT IS perhaps tactless to point it out, but France's rejection of the European Union constitution is, in lots of ways, a triumph for Britain. For at least 50 years, the British have had two main goals in Europe. The first was to blunt the drive towards European political union; the second, to prevent Franco-German domination of European politics. With the death of the constitution both goals have been achieved at once. ${ }^{202}$

This last article suggests the reason why the Franco-German couple tends to be viewed negatively by the British press, but there has been no indication, present in other papers, that Germany would be viewed favourably by the Economist if it was not a part of this bloc.

The focus of those articles coded as pure negative was economic, which we have found to be the case in the past, and which is in keeping with the theme of the newspaper. This coverage did, however, take two forms, namely criticizing the actions of the FrancoGerman axis, and describing what was perceived as the failure of the German economic model:

Similarly, the stability and growth pact pledges members of the single currency not to run budget deficits of more than $3 \%$ of GDP, a commitment that is again enshrined unchanged in the constitution. Yet France and Germany are on course to violate the ceilings for four years in a row, and seem happy to continue doing so. ${ }^{203}$

\footnotetext{
201 "Dead, but not yet buried- The European Constitution," Economist, June 4, 2005.

202 "The triumph of perfidious Albion- Charlemagne," Economist, June 4, 2005.

203 "Pieces of paper- Charlemagne," Economist, June 19, 2004.
} 
But there might just be a silver lining to this affair. It clearly shows how bad a job German leaders, in both government and opposition (and, it must be said, in business and finance as well) have done of explaining the need for reforms...Germany may have to go through such an episode to understand finally that its economic model is past its prime, and needs an overhaul. The underlying truth is already clear: the country needs a freer, more flexible form of capitalism, not a hunt for scapegoats. ${ }^{204}$

On the Economist therefore, we are able to say that there is proof that the newspaper is more interested in Germany within the context of European integration, but not that this interest consistently manifests in terms that are positive or negative. We have also seen that the newspaper carries on the theme of portraying the Franco-German couple in negative terms, which has been a common feature of every other newspaper in this focal point. However, this theme has not emerged in past coverage of the Economist, suggesting that the attitudes of the newspaper towards Germany ebb and flow over time. Economics does remain a principle issue, but this is to be expected given the nature of the publication.

\section{$\underline{\text { Section Conclusions }}$}

In this section, we have reached a number of conclusions respecting British press coverage of Germany, in general, and with respect to the attitudes of particular newspapers in specific contexts. For the press in general, we have concluded that there is a minimal amount of positive coverage concerning Germany, and that this is consistently true both within and outside of an EU context. We have further seen that the majority of British press coverage of Germany is neutral, although neutral-negative and pure negative articles make up a significant percentage of overall reporting, ranging from approximately $20 \%$ to $45 \%$. With this information, we were able to qualify the currently

204 "Bogus backlash- German capitalism," Economist, May 7, 2005. 
existing notion that the British press is generally negatively disposed towards Germany by noting that this is only true when neutral coverage is discounted, and it is actually more accurate to say that the British press is more inclined to be negative than positive when Germany is discussed. We were also able to measure the degree of this negativity, concluding that it tends to be subdued rather than blatant. Finally, we saw no indication that overall British press attitudes regarding Germany changed within an EU context.

By looking at how the five newspapers within this project compared to each other, we were able to draw further conclusions. We saw that, regardless of context, the three broadsheets, the Times, Independent, and Guardian, remained quite consistent in their relative negativity towards Germany, with the Times routinely displaying the most negativity, and the Guardian the least. We also saw that these three newspapers ran a majority of neutral coverage concerning Germany in all focal points.

On an individual level, we found that the attitudes in the Daily Mail fluctuated and also seemed to reflect political relations between Britain and Germany at a given time. Non-neutral coverage of Germany in this newspaper tended to be particularly negative, and this did not change significantly within an EU context. Within this latter context, we saw that the Daily Mail consistently portrayed the Franco-German partnership as a sinister force within Europe that often acts against the wishes of Britain. Themes such as German power and militarism also appeared, although these were also shared with the test case. For the Times, we were able to conclude that there was ample evidence that the newspaper was more negatively disposed towards Germany within an EU context, very likely because of its status as a Eurosceptic paper. We also saw that the Times was extremely interested in the Franco-German partnership, and consistently 
portrayed this bloc as a negative opponent. Finally, themes such economics and power were found to be common to coverage of the Times when it discussed Germany, regardless of the context.

We found the Independent to be generally consistent in its attitudes towards Germany across all focal points, and like previous newspaper, considerations of the Franco-German relationship factored high, although this was not necessarily portrayed in the same negative terms as for other newspapers. Additionally, the themes and emphases that emerged in each focal point tended to vary. For the Guardian, we concluded that the newspaper was more interested in German activities within an EU context, due to an increase in positive and negative coverage in all related focal points when compared to the test case. We also saw that there was a recurring tendency to portray Germany negatively within an EU context when it was allied with France, and third, like the Times, the Guardian was more inclined to view Germany in less negative terms when this was not the case. Finally, while the Economist was found to be more interested in Germany within an EU context, the attitudes of the newspaper also appeared to ebb and flow with time, meaning that there were no clear positive or negative trends in its coverage. As expected, economics was usually the principle issue discussed.

What can be said of the British press at this point that there is no great difference in attitudes that emerge between discussions of Germany within an EU context, or outside of it. The position of a newspaper regarding European integration does not seem to matter a great deal in its attitudes towards Germany, although we have seen for the Eurosceptic Times that there is evidence of a strengthening of negative attitudes within an EU context. Generally, however, a newspaper's attitudes remained comparable to those 
discovered in the test case. This would seem to indicate that there is a predetermined set of attitudes about Germany that influence the coverage in the five newspapers examined here, with the exception of the Economist, where attitudes were found to fluctuate. We have, however seen some very conclusive evidence, through shared and repeated themes, that the British press is actively engaged in constructing an image of Germany within an EU context. However, consideration of these points must wait until the final conclusion.

\section{Eye on Britain: German Press Coverage of the European Constitution}

Newspaper Coverage and Interpretation Overall

The data for this section comes from 166 newspaper articles taken from the time period of the EU constitution focal point, the specifics of which have been detailed previously. Readers will note that relevant coverage in the German press is significantly higher for this focal point than it was for either Amsterdam or Nice (which ran 38 and 90 articles respectively), but also much lower than relevant coverage in the British press, which was made up of 331 articles. Recalling that this last point was also the case for the Amsterdam and Nice focal points, we can now be reasonably confident in the accuracy of our previous hypothesis, which stated that:

The British are more interested in Germany's role in the EU than Germany is in Britain's.

Moving back to German press coverage, the breakdown of coding for all articles was as follows: 
Fig. 3.19: Article Coverage- All Newspapers

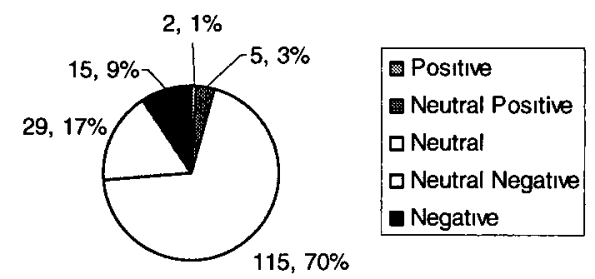

This graph is generally unspectacular when compared to the findings from previous focal points. It contains a high neutrality count, and neutral-pure articles outweigh those coded as either pure negative or pure positive, which has always been the case previously:

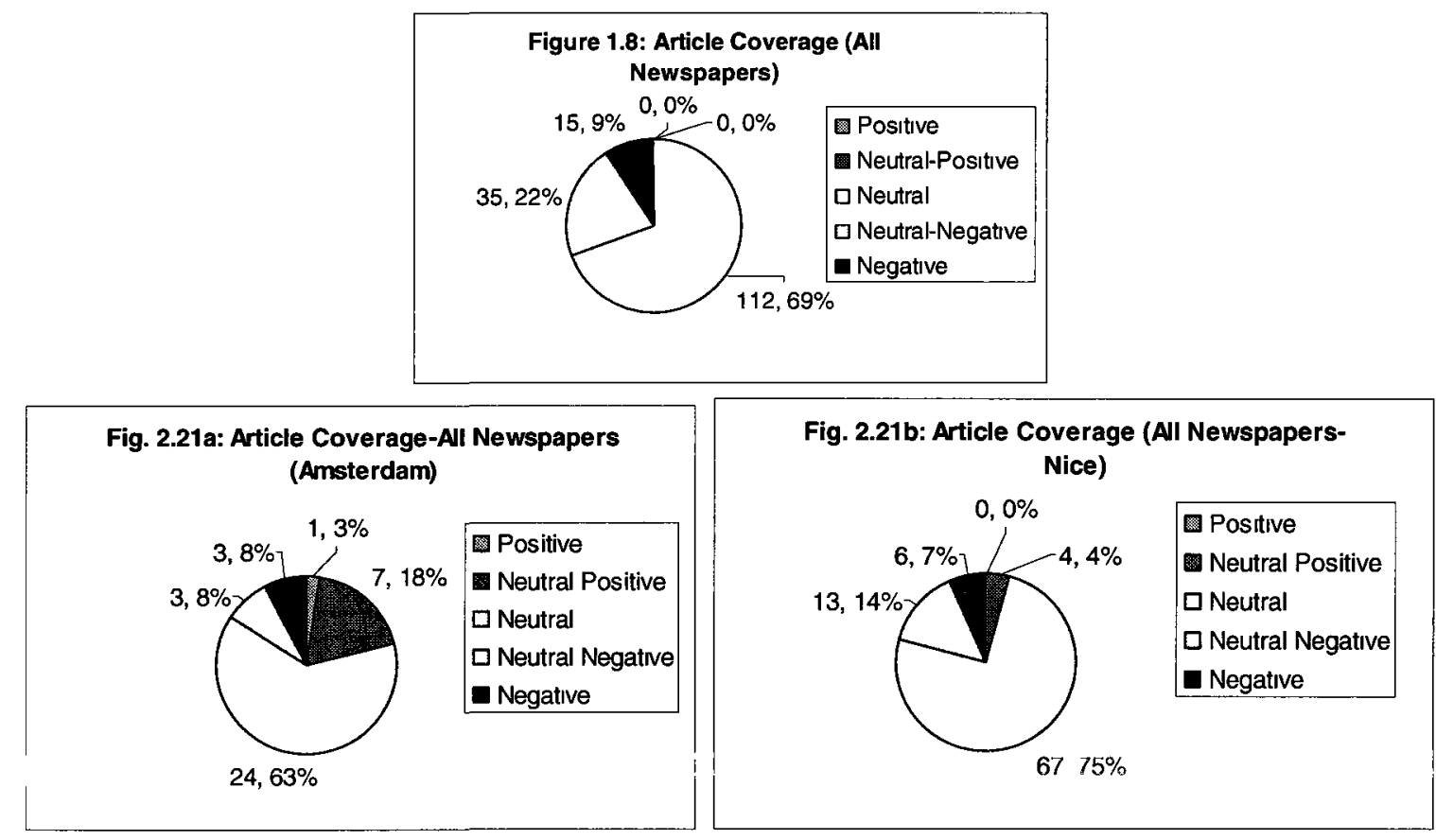

These findings allow us to draw a number of conclusions about the German press in general. Noting that the lowest percentage of neutral articles in any focal point is $63 \%$ and the highest is $75 \%$, we can say that:

Regardless of context, the majority of German press coverage regarding Britain is neutral, and the proportion of neutral articles remains remarkably consistent at approximately $2 / 3$ to $3 / 4$ of all coverage. 
The amount of pure negativity displayed in the German press towards Britain is also remarkably consistent between all focal points, ranging from $7 \%$ at the lowest to $9 \%$ at the highest. The percentage of neutral-negative articles displays more variation, going from $8 \%$ at the lowest to $22 \%$ at the highest, but we can nonetheless state that:

The proportion of negative articles that concern Britain is reasonably consistent, regardless of context.

We are not able to say the same thing about positive articles, which vary between being absent and making up almost $20 \%$ of coverage. As mentioned earlier, we have also noted that neutral-pure articles consistently outweigh pure value articles, meaning that:

Both positivity and negativity are more likely to be subdued rather than blatant when Britain is discussed.

The fact that little research currently exists on the German press as it relates to Britain means that these are important findings. Finally, the fact that all of these conclusions are general rather than specific means that:

There is no indication that German press attitudes regarding Britain are affected by an EU context.

Some further conclusions can be found by examining the data from individual newspapers: 

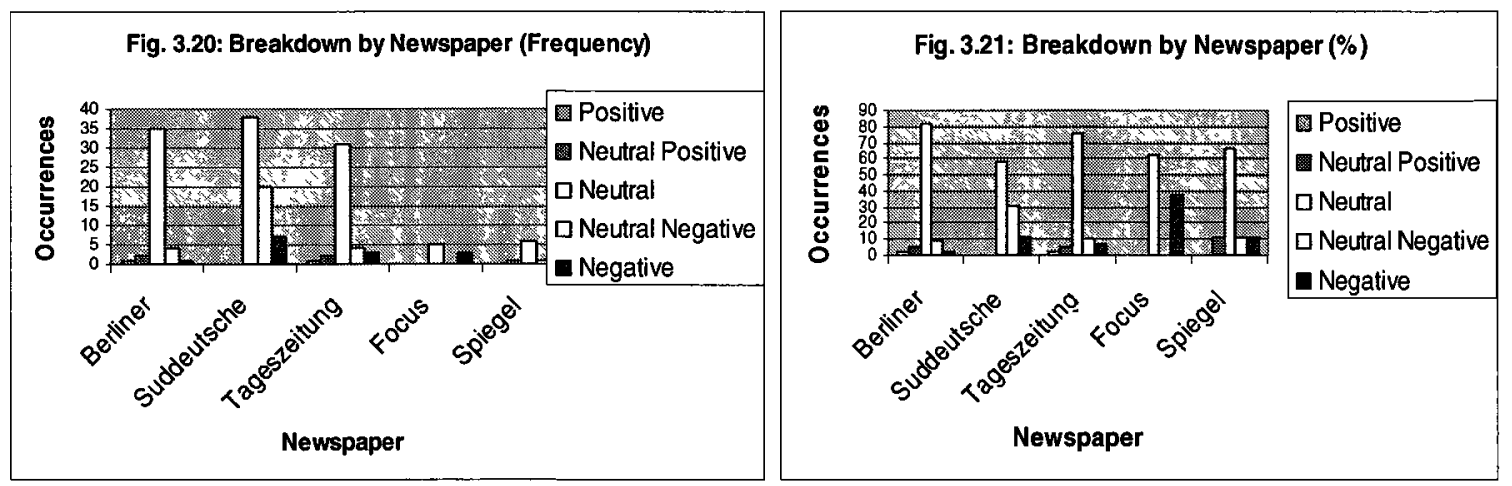

We can see for this focal point that all five newspapers contain a majority of neutral coverage, which is in line with the general conclusions above. We can also see that, in every case, the combination of negative articles outweighs the combination of positive. Beyond this, we can see that the Berliner Zeitung and the Tageszeitung compare quite well in terms of proportional attitudes, although for the remaining three newspapers this is not necessarily the case. Turning to our findings from previous focal points:

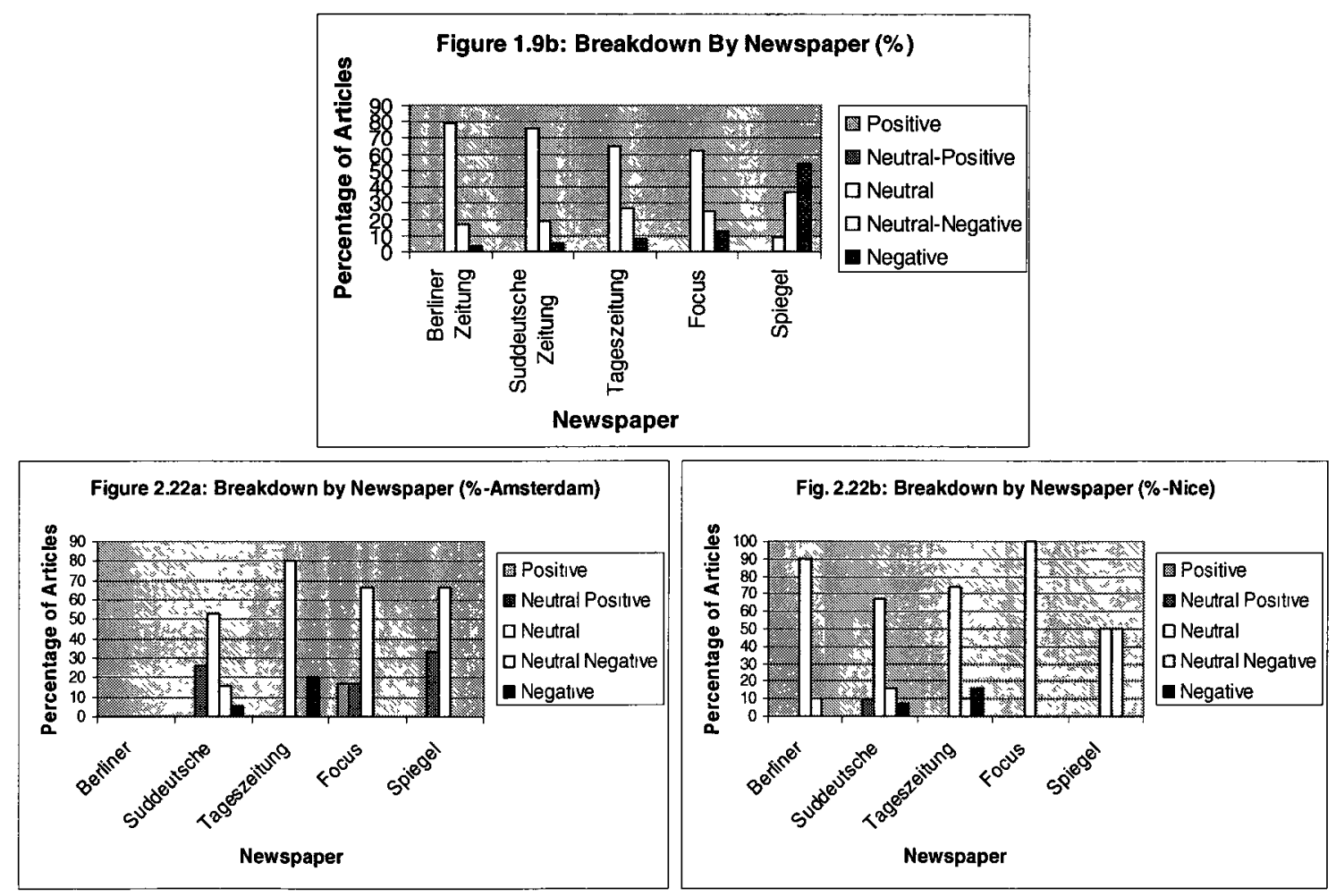

On an individual basis, we can say with certainty that: 
Every newspaper, with the exception of Der Spiegel, consistently runs a majority of neutral articles when discussing Britain.

Referring to the attitudes in Der Spiegel, we can see that they are markedly inconsistent from one focal point to the next, within or outside of an EU context. The same is also true of FOCUS, which, with reference to the EU focal points, varies between more positive stories in one, more negative stories in another, and complete neutrality in a third. We can therefore state:

The attitudes that the weekly newspapers display towards Britain are incredibly inconsistent from one focal point to the next. The broadsheets, by comparison, are more consistent.

Recalling that, in previous chapters, the descending negativity of the Tageszeitung, Süddeutsche Zeitung, and Berliner Zeitung was found to remain consistent, it becomes apparent here that this trend has been bucked, with the Süddeutsche Zeitung outweighing the Tageszeitung in overall negativity. The Berliner Zeitung, however, continues to be the least negatively disposed towards Britain. We can therefore say that:

The relative negativity between the Berliner Zeitung and Tageszeitung remains constant in any focal point, and this is also generally true of the Süddeutsche Zeitung with these two newspapers, which displays this consistency in 3 of 4 cases.

Finally, these graphs tend to confirm our hypothesis from earlier chapters that:

The degree of positive and negative attitudes that each individual newspaper expresses towards Britain is generally inconsistent from one focal point to the next, and variation exists even within an EU context This would seem to indicate a lack of set attitudes on the part of any newspaper. 
Individual Trends and Themes

The list of common emphases that appeared in the German press coverage of the EU Constitution focal point is shorter in this chapter than it has been previously, although all of these are similar to ones that we saw in coverage from the Amsterdam and Nice focal points. There are three themes in total, and they are as follows,

1) Britain as an opponent of Germany or German desires, or Britain as otherwise representing an entity that is contrasted with Germany.

2) Britain as being a general laggard, inhibitor, or blocker of European integration initiatives.

3) The British people as isolationist, Eurosceptic, or anti-EU.

Although these themes in theory do not correspond to a given coding value, it is clear that many of these are more likely to be negative than positive. It should be mentioned, however, that none of these themes are repeated with the same frequency as those in the corresponding British chapter. Where previously we have counts for a given theme that ran as high as 50 or 60 for a single source, here none of these even reach ten occurrences per newspaper. While this is to some extent a result of the lower number of relevant articles than appeared in the British case, it is also clear that the German press does not hammer on the same themes with the frequency of its British counterpart. Referring back to the numbers that appeared in each case from the previous two EU focal points, and this becomes a general truth. We can thus state that: 
Within an EU context, the German press does not resort to common themes when portraying Britain to the same extent that the British press does when discussing Germany.

This finding has ramifications for national image construction in both countries, as well as British identity, both of which will be discussed in the conclusion. For now, however, we turn to an examination of the trends and themes that emerge in individual newspapers.

For the purposes of this section, both Der Spiegel and FOCUS will be examined together. This is because both sources ran a low number of relevant articles for this focal point ( 9 and 8 respectively), and also because we have already drawn some general conclusions about these newspapers, namely that their attitudes towards Britain vary widely from one focal point to the next, and are not set according to a given topic. What remains to be examined is to what extent themes remain consistent, both within this focal point, and with regards to earlier reporting. Figures 3.22 and 3.23 show the extent to which the attitudes of each newspaper vary between focal points:
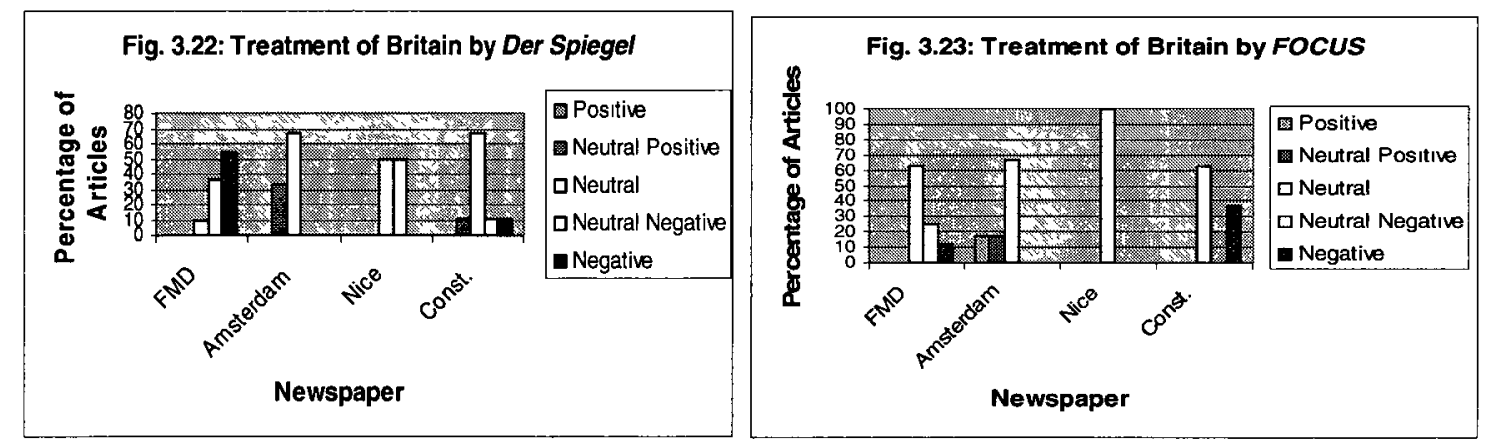

With reference to the EU Constitution focal point, we can see that both sources ran a majority of neutral articles and neither ran any pure positives, but other than that, attitudes were dissimilar. Referring back to Figure 3.21, we can see that FOCUS is proportionally the most negative newspaper in this focal point, while Der Spiegel ranks 
third in negativity but first in positivity. Der Spiegel also ran neutral-pure articles, whereas FOCUS ran none. Comparing the coverage of each newspaper with its coverage in past focal point further indicates that FOCUS is at its most negative during the EU Constitution, while Der Spiegel is at its most moderate. This former finding does away with the hypothesis from the last chapter, which suggested that FOCUS might generally be positively disposed towards Britain.

The low number of relevant articles from each source makes trends over time difficult to gauge, although it has been possible to graph some data from both newspapers. It should be noted that no relevant articles were run in Der Spiegel in the month of May 2005, but the magazine otherwise contained the following trends:
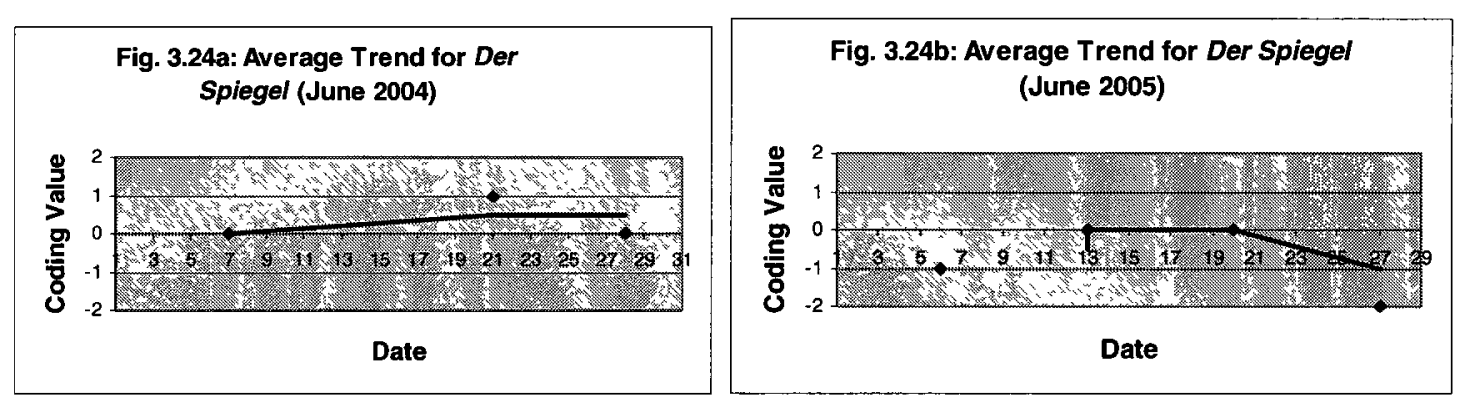

We can see that coverage of Britain ranged between neutral and neutral-positive in June 2004, but that this positivity was exchanged for negativity in June 2005. FOCUS ran relevant articles in all three months of the focal point, but the only month with sufficient data to be graphed was May 2005, where we can see that the trend was predominantly negative. Two articles apiece were run in June 2004 and June 2005, and these were coded as negative/neutral and neutral/neutral respectively. 


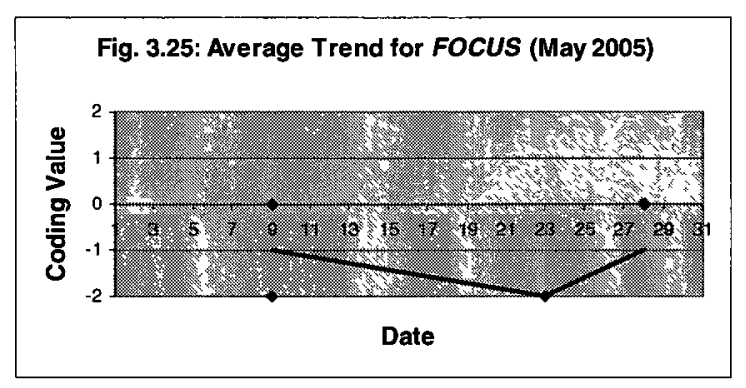

In terms of common themes and emphases, the findings for the two sources were as follows:
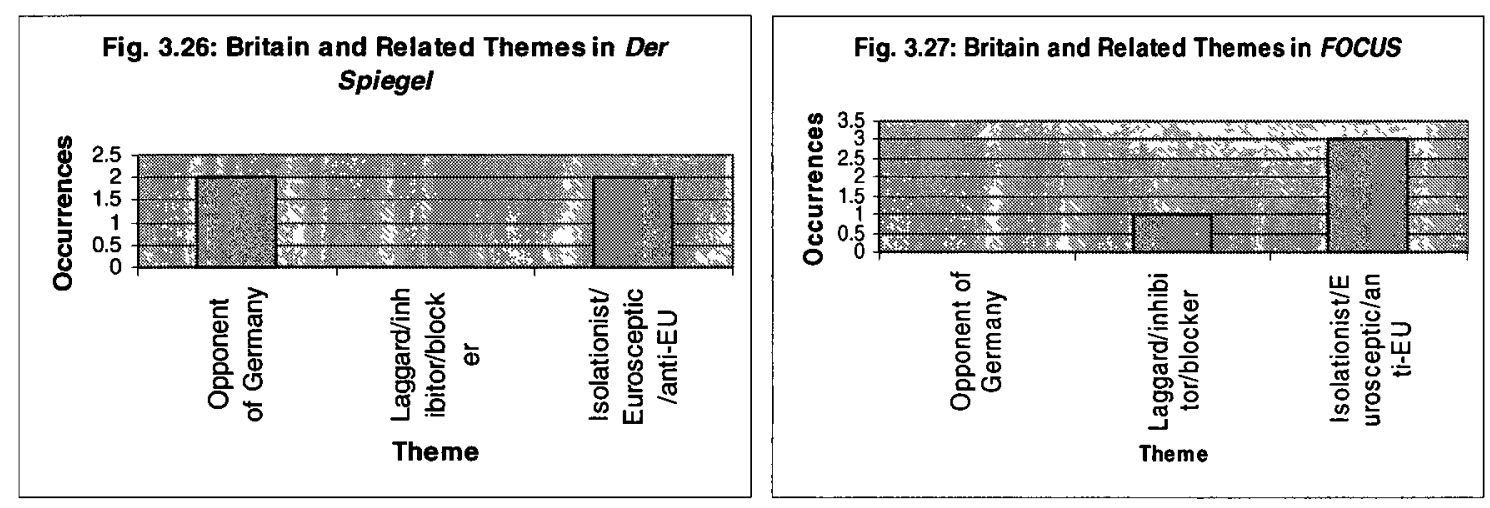

We can see that both Der Spiegel and FOCUS carry the common theme of the British being isolationist, eurosceptic and anti-EU, although the remaining two themes yield different results.

In terms of individual articles for the EU Constitution focal point, it has been mentioned that Der Spiegel ran positive articles, while FOCUS did not. This emerged in the form of one article coded as neutral-positive, which portrayed Britain in a semipositive light for giving some ground to the EU:

For many years the Britons fought against giving the union a legal personality. Now, however, they have agreed that the EU can really rise to become a "global player", as they have made it in their "Strategic Concept."205

205 "Vollig kindisch," Der Spiegel, June 21, 2004.German: Über viele Jahre wehrten sich die Briten dagegen, der Union eine eigene Rechtspersönlichkeit zu geben. Jetzt allerdings stimmten sie zu, dass die EU wirklich zum "global player" aufsteigen kann, wie sie es sich in ihrem Strategiekonzept vorgenommen hat. 
This indicates a willingness of Der Spiegel to view the British more positively when they act in a pro-European manner, which is in line with our findings from the previous EU focal points. It should be noted, however, that the tendency to stereotype the British which also appeared previously was not present to the same extent in this focal point. In terms of neutral coverage, those articles found in both Der Spiegel and FOCUS concerned the same topics. During June 2004, the focus was on the negotiations taking place at the European Council meeting, and in May-June 2005, the emphasis was almost exclusively on the question of the British constitutional referendum. Despite having different particular focuses, the negative articles run by both newspapers also shared a common theme in portraying the British as bad Europeans. In FOCUS, which ran only pure negative articles, the emphasis was on British Euroscepticism. Two of these articles were specific in discussing the ignorance of particular groups of British Eurosceptics, with one discussing UKIP and the EP, and the other stating:

The Eurosceptics in Great Britain are pulling no punches in attacking the mainland, which is forever fueled by erroneous stories in the London tabloids. Some say that the EU wants to forbid singing in football stadiums, another time it was the case that 10-Euro notes caused impotence. ${ }^{206}$

A third and final article was more general in its criticism, stating "from Briton Tony Blair, whose countrymen are Eurosceptic like no others, an initiative to save the constitution is not to be expected."207

The negative coverage in Der Spiegel was similar, in that criticism was often not directed at Britain in general, but rather at Tony Blair. The one neutral-negative article

\footnotetext{
206 "Alarm in Raumschiff," FOCUS, May 9, 2005. German: Die Euro-Skeptiker in Großbritannien schießen aus vollen Rohren aufs Festland, immer gefüttert mit irren Geschichtender Londoner Boulevardpresse. Mal heißt es da, die EU wolle das Singen in Fußballstadien verbieten, ein anderes Mal, 10-Euro-Scheine verursachten Impotenz.

207 "Vielflieger Schröder," FOCUS, May 23, 2005. German: Vom Briten Tony Blair, dessen Landsleute europaskeptisch wie wenige andere sind, ist eine Initiative zur Rettung der Verfassung nicht zu erwarten.
} 
spoke on the hypothetical postponing of the EU constitutional referendum in Britain, suggesting that "if Blair blows off the referendum in order to avoid a defeat, he should be made responsible for the failure of the constitution." 208

Der Spiegel also ran one pure negative article, which cast Blair as a ruthless opportunist and beneficiary of Europe's failure:

Briton-Premier Tony Blair used the crisis of the European Union in order to promote his concept of economic renewal...For eight years he was an outsider on the European stage, largely without influence...then the referendums on the constitutional treaty failed in France and the Netherlands and Blair, coldbloodedly, as he is in truth, exacerbated the crisis of confidence by allowing the Brussels summit to collapse. ${ }^{209}$

It is obvious from these findings that Der Spiegel and FOCUS share common ground in this focal point, in that they both portray Britain negatively when it, or specific actors within it, are perceived to be anti-European. Recall that previous findings from both of these sources during the Amsterdam and Nice focal points were also related to the degree of Britain's europhilism, and we can conclude that the position of both Der Spiegel and FOCUS on European integration affect their attitudes regarding Britain, which fluctuate depending on its actions in the European integration process.

Coverage from the Tageszeitung for this focal point is made up 41 articles, which is significantly more than either Der Spiegel or FOCUS, but also considerably less than the Süddeutsche Zeitung, which contained the highest number of relevant articles at 65 . Recalling that the attitudes in the Tageszeitung have remained relatively consistent in the

\footnotetext{
208 “Europa im Jahr null ,” Der Spiegel, June 6, 2005. German: Wenn Blair das Referendum abbläst, um eine Niederlage zu vermeiden, soll er für das Scheitern der Verfassung verantwortlich gemacht werden. 209 "Pardon wird nicht gegeben," Der Spiegel, June 27, 2005. German: Briten-Premier Tony Blair nutzte die Krise der Europäischen Union, um für sein Konzept wirtschaftlicher Erneuerung zu werben. ...Acht Jahre lang war er Außenseiter auf der europäischen Bühne - weitgehend einflusslos...dann scheiterten die Volksabstimmungen zum Verfassungsvertrag in Frankreich und den Niederlanden, und Blair - kaltblütig, wie er in Wahrheit ist - verschärfte die Vertrauenskrise noch, indem er den Brüsseler Gipfel platzen ließ.
} 
focal points examined so far, and it becomes clear from an examination of Figure 3.28 that there is a certain degree of rupture within the current focal point:

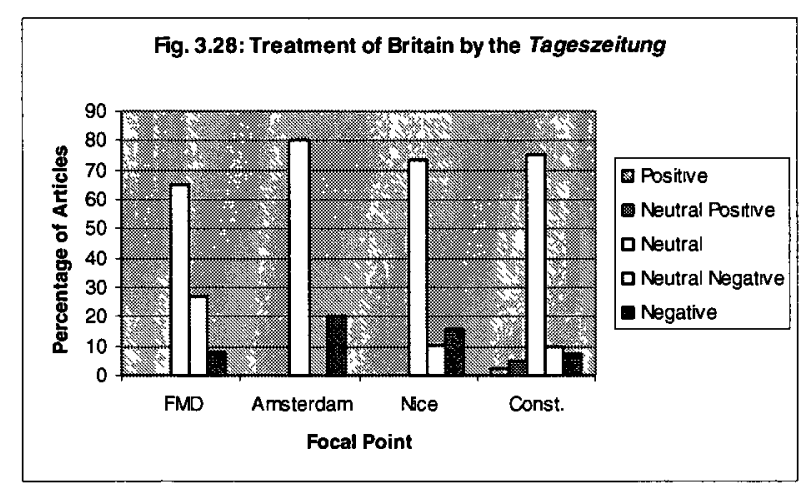

We can see that while the EU Constitution focal point contains the usual high neutrality count $(75.6 \%)$, it is the only one that contains any neutral-positive or pure positive articles, and furthermore, with regards to the other EU focal points, neutral-negative reporting here outweighs pure negative. These findings water down hypotheses from previous chapters, but do not altogether discredit them. Because negative articles still outweigh positive, we can say that positive coverage of Britain in the Tageszeitung is negligible regardless of context, and the newspaper is generally negatively disposed towards Britain when not simply passively reporting on a given situation. Further, we can also say that within an EU context, the Tageszeitung is more likely to be blatantly negative in its coverage of Britain, although this is not always the case.

The trend lines for the Tageszeitung within the EU Constitution focal point are as follows: 

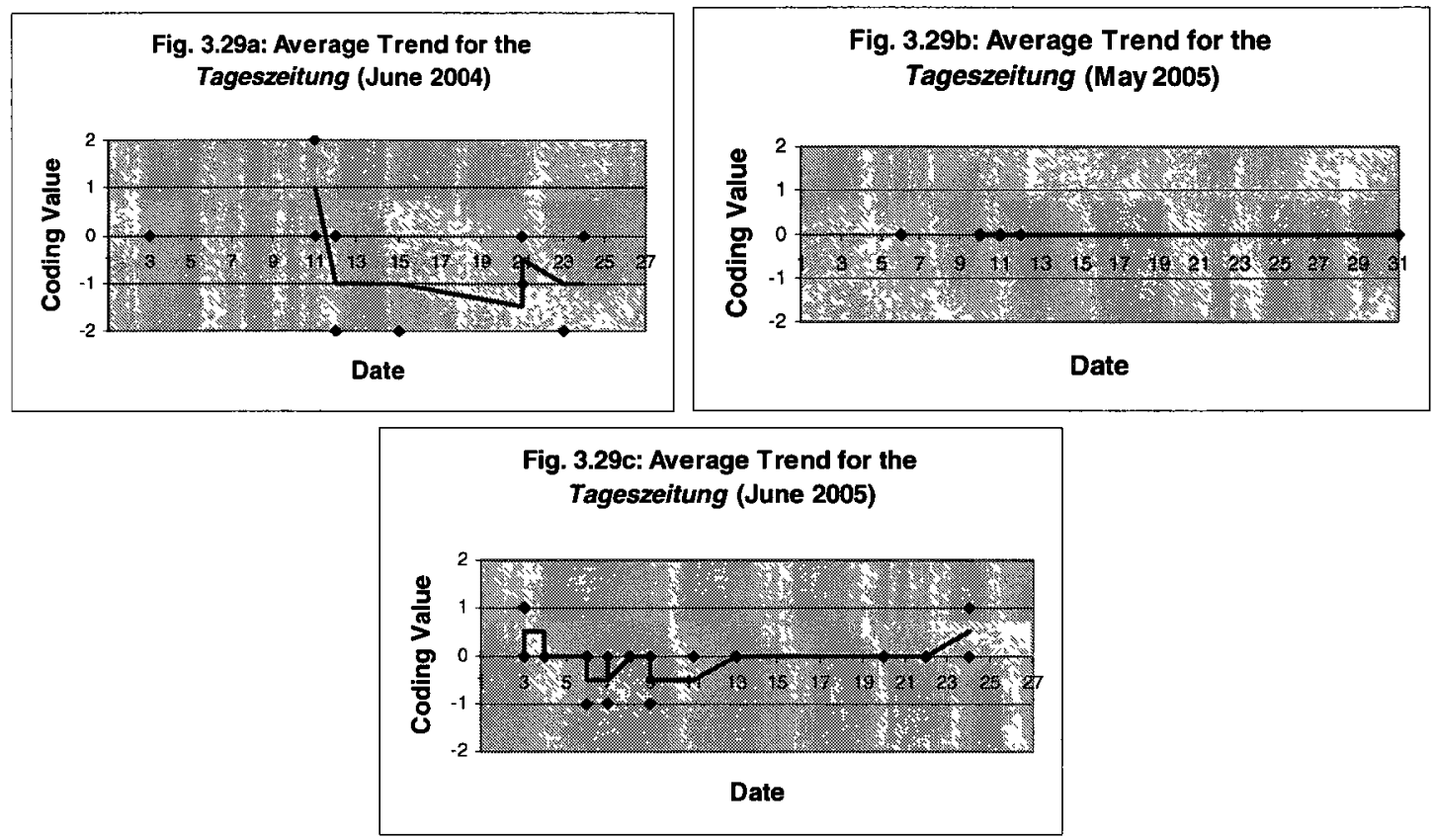

Interestingly, Figure 3.29a shows us that all of the pure negative articles fall within June 2004, the month when the final negotiations on the EU constitutional treaty were taking place. The trend for May 2005 is entirely neutral, and the one for June 2005 shows only minor positive and negative fluctuations around an overall neutral trend. Recalling that coverage for the Amsterdam and Nice focal points was marked by a higher pure negative count than neutral-negative, and that the time period for both of these focal points surrounded the summits themselves, and we can conclude with reasonable certainty that within an EU context, the Tageszeitung is more likely to report on Britain in purely negative terms during summit negotiations than at other times.

In terms of the common themes listed above, the Tageszeitung scores as follows: 


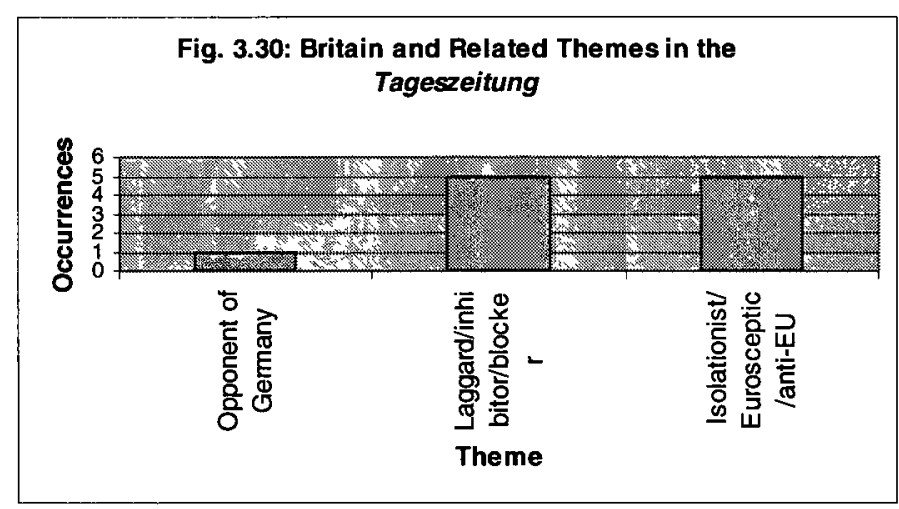

The newspaper scores relatively high for portraying the British as both blockers and laggards in the European integration project, as well as for being isolationist, Eurosceptic, and anti-EU. The finding in the former category is consistent with the Tageszeitung's coverage during both the Amsterdam and Nice focal points, and the latter lines up with the emphases of both Der Spiegel and FOCUS within the current focal point.

It has been previously mentioned that approximately three-quarters of the Tageszeitung coverage that discussed Britain within this focal point was neutral. Within this category, the vast majority of articles were concerned with the British referendum on the EU constitutional treaty. Coverage in June 2004 tended to simply mention that Britain was one of the countries that had announced it would hold a referendum, and coverage from May-June 2005 discussed the possibility of its postponement as well as the eventual reality of this. It has also been mentioned that coverage from the Tageszeitung within the current focal point contained both positive and neutral-positive articles. One of the positives mentioned the British referendum and praised Tony Blair for his diplomatic courage, stating "if the British Prime Minister Tony Blair is now tying his political fate to 
a referendum on the EU constitution, he is in any case showing more democratic courage than all of the EU parliamentarians combined., ${ }^{, 210}$.

There were two articles coded as neutral-posiive, both of which came from June 2005. The first simply followed coverage from a newspaper in the Netherlands, which had stated that the British had come up with the most reasonable idea (by calling for a period of reflection and consultation) following the failure of the constitution in the French and Dutch referendums. ${ }^{211}$ The other article also mentioned Tony Blair and expressed hope in the upcoming British presidency, stating "with Blair, a debate on the future of Europe is instead possible. Instead of speaking on constitutional texts, he wants to talk about real life." ${ }^{212}$ Positive articles in the Tageszeitung thus follow a general trend in praising Tony Blair for pro-European actions. Although no previous positive articles existed within the EU focal points, this complements a previous hypothesis that the Tageszeitung's attitudes are tied to how positively Britain (or its representatives) acts in the European integration project.

The findings for the neutral-negative and negative articles bear this out. The former either tend to emphasize the British as the primary blockers of European initiatives, or lament the cancellation of the British referendum as heralding the death of the EU constitution. Speaking on the draft constitution, an article from the June 2004 negotiation period states:

In fact, the need for unanimity in sensitive areas of interior-and-justice policy, and in all areas of foreign-and-defence policy, has remained. That means, conversely,

\footnotetext{
210 "Verhöhnung der Demokratie," Tageszeitung, June 11, 2004. German: Wenn der britische Premier Tony Blair jetzt sein politisches Schicksal an ein Referendum zur EU-Verfassung knüpft, beweist er jedenfalls mehr demokratischen Mut als alle EU-Parlamentarier zusammen.

211 "die anderen über die eu ohne verfassung," Tageszeitung, June 3, 2005.

212 "Tony Blair, Glücksfall für Europa - Kommentar von Dominic Johnson," Tageszeitung, June 24, 2005. German: Mit Blair wird stattdessen eine Debatte über die Zukunft Europas möglich. Statt über Verfassungstexte will er über das wirkliche Leben sprechen.
} 
that one country can thwart the other 24 governments. That this blocking veto always has to come from the British side is, of course, not found in the constitutional treaty. ${ }^{213}$

On the second topic, an article from June 2005 states:

Now the British have postponed the referendum indefinitely. What consequences will this have? That is practically the third "No" to the constitution. With this, the British strengthen the negative domino effect without even having clearly said "No". We must now expect that the Luxemburgers and Danes will also say no. ${ }^{214}$

As previously mentioned, all of the pure negative coverage from the Tageszeitung came

from June 2004. There were three such articles run during this period, all of which carried on the theme of the British being laggards or anti-European. The most blatant stated:

We are mad to recruit more and more Britons into the EU. We even integrate states that do not want to be integrated. If they only want the economic advantages, they should remain outside. 215

It is clear, then, that the Tageszeitung is consistent, both within this focal point and in others, in treating Britain in a negative manner when it acts in anti-European ways. In closing with our consideration of this newspaper, we can say a number of things. First, we have seen that positive coverage of Britain is negligible regardless of context, and the newspaper is generally negatively disposed towards Britain when not simply passively reporting on a given situation. Second, we have noted that, within an

213 "Berties einzigartiges Erlebnis," Tageszeitung, June 21, 2004. German: Tatsächlich ist der Zwang zur Einstimmigkeit in sensiblen Bereichen der Innen-und Justizpolitik sowie in allen Grundsatzentscheidungen der Außen-und Verteidigungspolitik geblieben. Das bedeutet im Umkehrschluss, dass ein Land die anderen 24 Regierungen ausbremsen kann. Dass dieses blockierendes Veto immer von britischer Seite kommen muss, steht freilich nicht im neuen Verfassungsvertrag.

214 "Die EU hat eine große Zukunft vor sich," Tageszeitung, June 9, 2005. German: Jetzt haben auch die Briten das Referendum auf unbestimmte Zeit verschoben. Was für Folgen wird das haben? Das ist praktisch das dritte Nein zur Verfassung. Damit verstärken die Briten den negativen Dominoeffekt, ohne selbst eindeutig Nein gesagt zu haben. Wir müssen nun damit rechnen, dass auch die Luxemburger und Dänen Nein sagen werden.

215 "Die EU ist schon jetzt zu groß, sagt Peter Glotz," Tageszeitung, June 23, 2004. German: Wir sind verrückt, immer mehr Briten in die EU zu holen. Wir integrieren Staaten, die gar nicht integriert werden wollen. Doch wenn sie nur wirtschaftliche Vorteile wollen, dann sollen sie draußen bleiben. 
EU context, the Tageszeitung is more likely to be blatantly negative in its coverage of Britain, especially during times of summit negotiations. Finally, we have found that this negativity is directly linked to anti-European moves on the part of Britain, and for this reason, the newspaper often portrays the British as inhibitors of further European integration, or simply as anti-European. We have also seen that the newspaper is willing to treat Britain more positively when it acts in a more pro-European manner, and these last findings are therefore consistent with the newspaper's pro-integration position.

Coverage from the Berliner Zeitung for the EU Constitution focal point is composed 43 articles, which is quite similar to the quantity from the Tageszeitung. The Berliner Zeitung is also similar to the Tageszeitung with regards to the breakdown of attitudes in this focal point, as can be seen below:

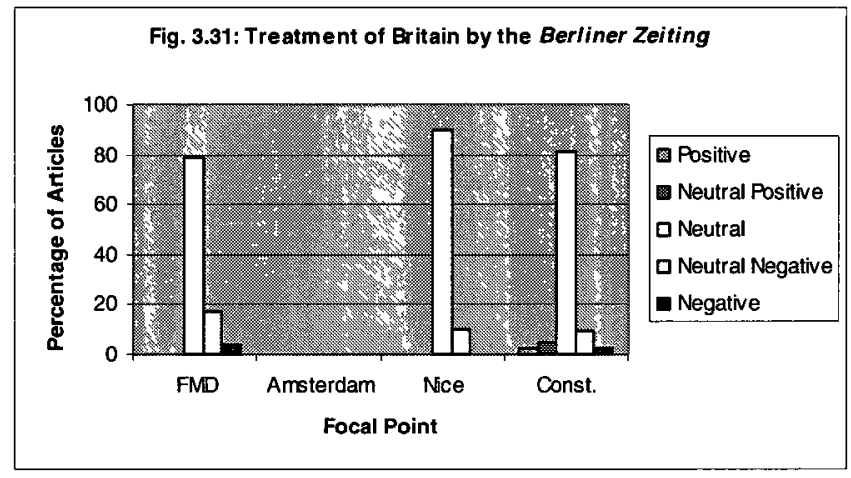

Coverage from this focal point is once again marked by a very high neutrality count (81.4\%, which compares with $80 \%$ from the FMD focal point and $90 \%$ from Nice), making the Berliner Zeitung the newspaper most neutrally disposed towards Britain in this focal point (and also the least negative), as well as the most consistently neutral newspaper overall. Like the Tageszeitung, this newspaper only contained positive and neutral-positive articles within the EU Constitution focal point, though unlike the Tageszeitung, neutral-pure articles consistently outweigh pure-coded articles in all focal 
points. Additionally, the percentage of pure-coded articles, either positive or negative, never rises above $3.8 \%$. The lack of data for the Amsterdam focal point makes a comparison of attitudes within an EU context difficult, but we can nonetheless state with reasonable certainty that the Berliner Zeitung treats Britain in an overwhelmingly neutral manner, regardless of context, and any positive or negative coverage that is present is likely to be subdued and negligible.

Figures 3.32a-c show the trends for the Berliner Zeitung in the EU Constitution focal point, which are generally unremarkable, reflecting the neutrality of the newspaper:
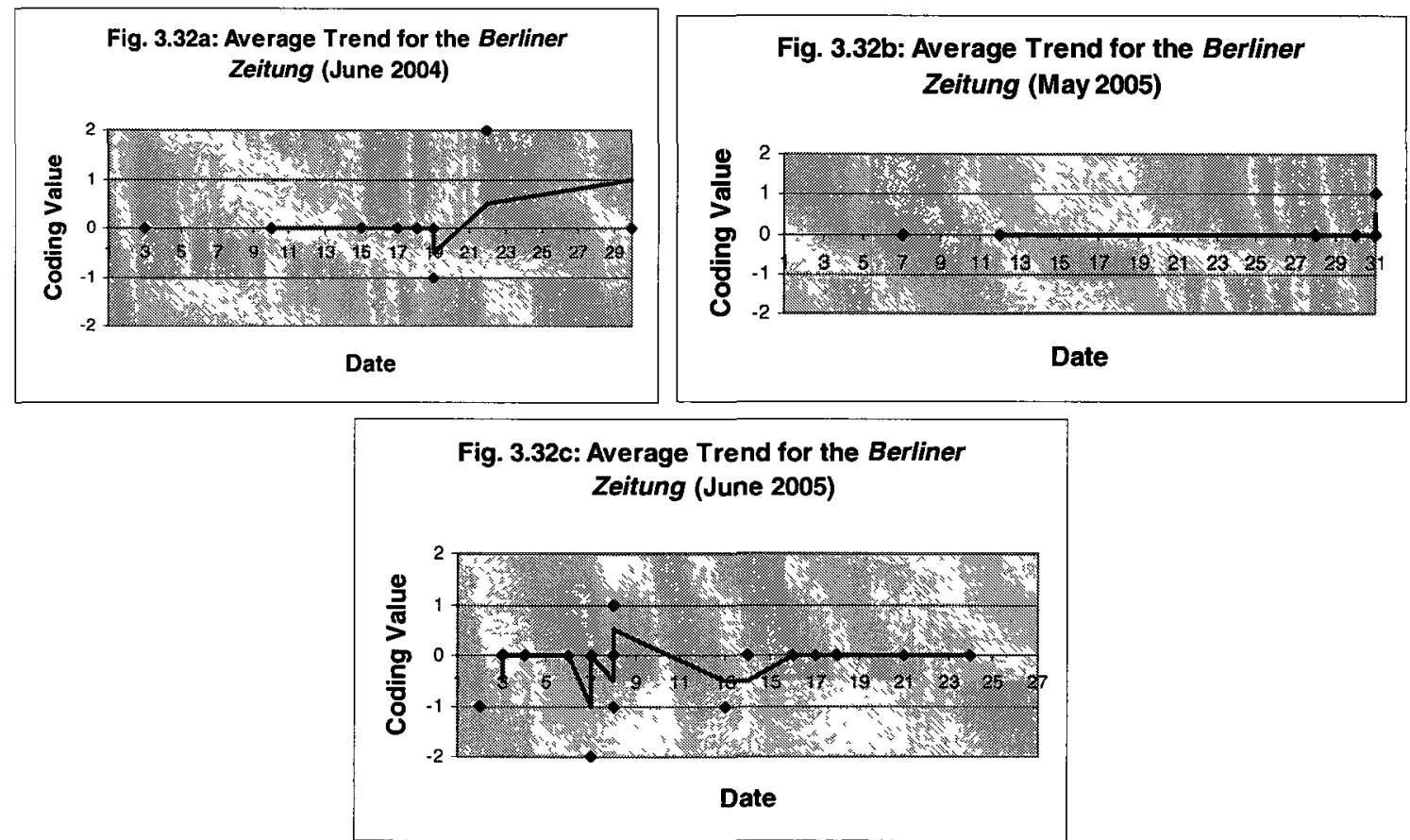

With regards to common themes and emphases, the Berliner Zeitung follows the tendency of the German newspapers in this focal point by portraying the British as either isolationist, Eurosceptic, or anti-EU. This tendency is not shared with findings from the Nice focal point, although there is still the occasional mention of Britain acting as an opponent of Germany. It is worth repeating at this point that these common themes are not present to the same extent that they are in British coverage of Germany. For example, 
of the 43 articles run by the Berliner Zeitung, only 7 suggest that the British are Eurosceptic or anti-EU.

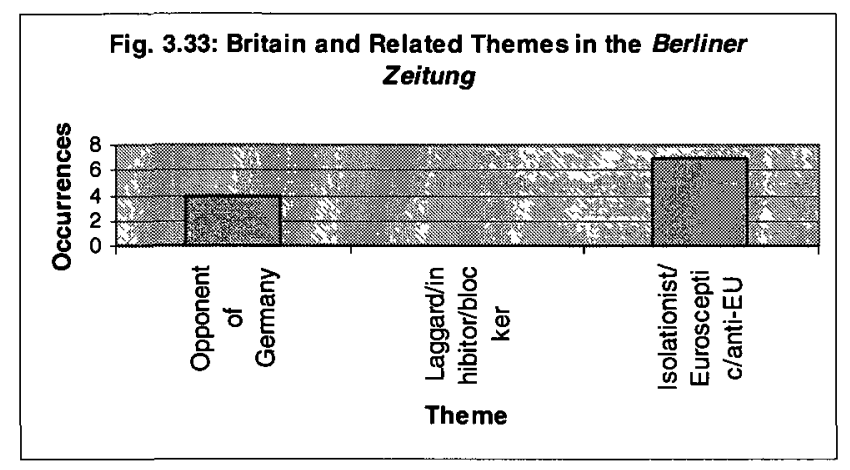

With regard to individual articles, neutral articles during June 2004 dealt with the negotiations taking place of the constitutional draft treaty, while neutral coverage from May-June 2005 was predominantly concerned with the question of the British referendum, as was the case with the neutral articles from the Tageszeitung. Neutralnegative articles, of which there were four in total, also took the British referendum as their subject. Unlike the coverage from previous newspapers, however, these did not tend to lament the British as the killers of the constitution, but rather tended towards stereotyping the British as traditionally Eurosceptic:

But the London government has made it clear that it will not present its traditionally Euroskeptic citizens with a treaty that has already failed in several states. $^{216}$

Similar skepticism has always led the British, who promptly suspended their referendum. ${ }^{217}$

\footnotetext{
216 "Nachschlag aus Holland - Die Niederländer lehnen die EU-Verfassung ab. Nun verschärft sich die Debatte, wie die Gemeinschaft aus der Krise zu führen ist," Berliner Zeitung, June 2, 2005. German: Die Londoner Regierung hat aber klar gemacht, dass sie ihren traditionell EU-skeptischen Bürgern kein Vertragswerk vorlegen wird, das bereits in mehreren Staaten gescheitert ist.

217 "Europaische Rollenspiele," Berliner Zeitung, June 13, 2005. German: ähnliche Skepsis leitet seit jeher auch die Briten, die prompt ihr Referendum aussetzten.
} 
The one article coded as pure negative did not refer to the British referendum, but rather discussed the upcoming British presidency of the EU and commented on the irony of the whole situation, given the British and their anti-European tendencies:

Sir Humphrey Appleby, the hero of the popular British satire "Yes, Minister," once said that Britain had really only followed one foreign policy strategy in the past five hundred years- the division of Europe...From the $1^{\text {st }}$ of July, the country takes over the EU presidency, and Blair must lead the European diplomatic league to a solution [to the constitutional crisis]. Not exactly a British specialty, if one thinks back to Sir Humphrey. ${ }^{218}$

It would at this point be tempting to state that the Berliner Zeitung tends to follow the trends of other German newspapers thus far by painting anti-EU actions in a negative light. However, the newspaper also ran one positive and two neutral-positive articles within this focal point. All of these dealt with the topic of the British constitutional referendum, and unlike the German newspapers examined so far, articles tended to justify British anti-European actions. The one pure positive article, taken from June 2004, openly stated that British skepticism regarding Europe was a good thing:

The question of the British is also completely justified... where is Europe to go? Who really wants a superstate? The skepticism of the British is good. And for it to really be taken seriously on the continent, Blair might have to lose the referendum. Paris and Berlin should be grateful to the British. ${ }^{219}$

The two neutral-positive articles once again dealt with the theme of the British constitutional referendum. The first stated that a British vote would be helpful to gauge popular feeling towards the European project, regardless of which way it went. The second relayed an article that justified postponement. It is therefore clear that the Berliner

\footnotetext{
218 "Großbritannien geht auf Konfrontationskurs - Die Blair-Regierung setzt das EU-Referendum ab / Hoffen auf ein Europa nach britischer Vorstellung," Berliner Zeitung, June 7, 2005.

219 "Einfahrt verboten - Warum die britischen Querelen gegen die Verfassung für Europa nützlich sind," Berliner Zeitung, June 22, 2004. German: Außerdem ist Frage der Briten durchaus berechtigt...Wohin soll Europa gehen? Wer will wirklich einen Superstaat?...Die Skepsis der Briten ist gut. Und damit sie auf dem Kontinent wirklich ernst genommen wird, muss Blair vielleicht das Referendum verlieren. Es wäre nicht der Untergang Europas. Paris und Berlin sollten den Briten dankbar sein.
} 
Zeitung does not follow the trends of the German newspapers expressed so far, in commenting positively on Britain when it acts in a pro-European manner, and negatively when it does not. In closing with our considerations of this newspaper, we can only say that, in addition to the previously mentioned high neutrality displayed by the Berliner Zeitung regardless of context, it also displays a certain amount of objectivity with regards to Britain's actions within an EU context, something that is lacking in other newspapers.

As previously mentioned, the Süddeutsche Zeitung ran the highest number of relevant articles for this focal point, with the total count being 65 . As with many of the German sources examined here, there is a certain amount of disconnect between the attitudes displayed by this newspapers within this focal point, and those that it displayed in others.

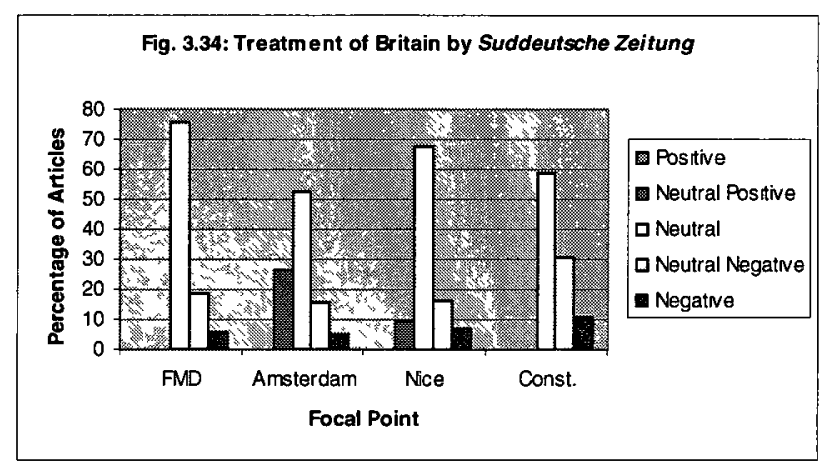

We can see from Figure 3.34 that there is a higher proportion of both neutral-negative and negative articles for this focal point than there have been for any previous one, and the high percentage of the former (30.8\%) in fact makes the Süddeutsche Zeitung the second most negative newspaper in this focal point after FOCUS. Additionally, while the percentage of neutral articles remains in the majority at $58.5 \%$, the Süddeutsche Zeitung is nonetheless the least neutral of the five newspapers examined here, and there is a 
notable lack of the positive reporting that appeared in both the Amsterdam and Nice focal points.

These findings discredit a number of hypotheses from previous chapters, namely that the newspaper may be more positively disposed towards Britain within an EU context, and that the combined negative coverage would remain consistent. It is clear, however, that regardless of context, the Sïddeutsche Zeitung runs a significant percentage of neutral-negative or negative articles concerning Britain, the combined value of which is never less than $20 \%$. Compared to this, pure-positive coverage is generally nonexistent, and the amount of neutral-positive articles is inconsistent. Finally, both negative and positive reporting is consistently subdued, rather than blatant.

Figures 3.35a-c show the trends for the Süddeutsche Zeitung for the EU Constitution focal point:
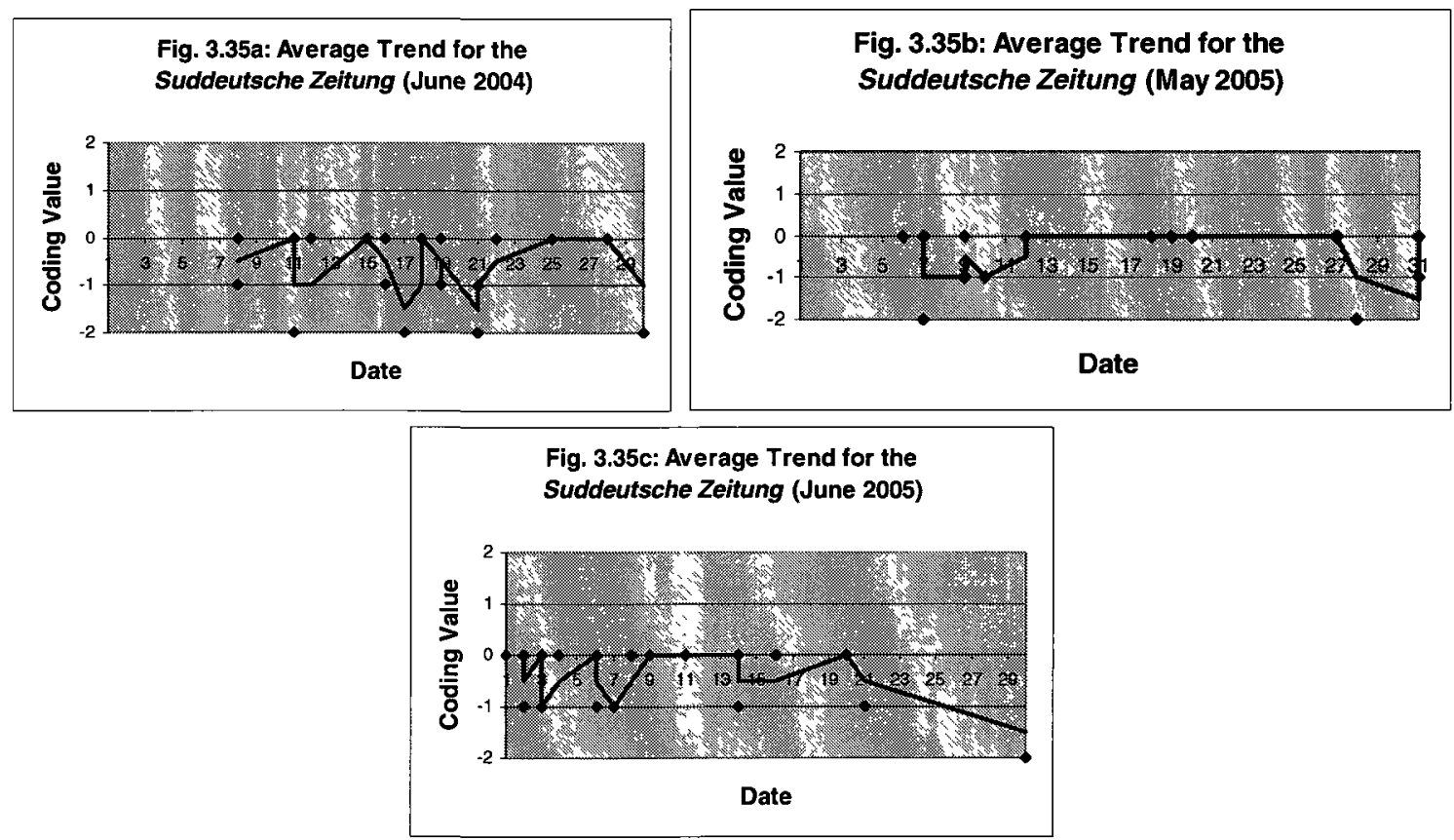

We can see in all cases that the trend alternates between neutral and neutral-negative, and occasionally dips deeper towards pure negative. There is increased activity surrounding 
important dates in the European integration process, but there does not seem to be any relationship between negativity and EU summits, as we found to be the case with the Tageszeitung. Regarding the common themes and emphases, the Süddeutsche Zeitung scores as follows:

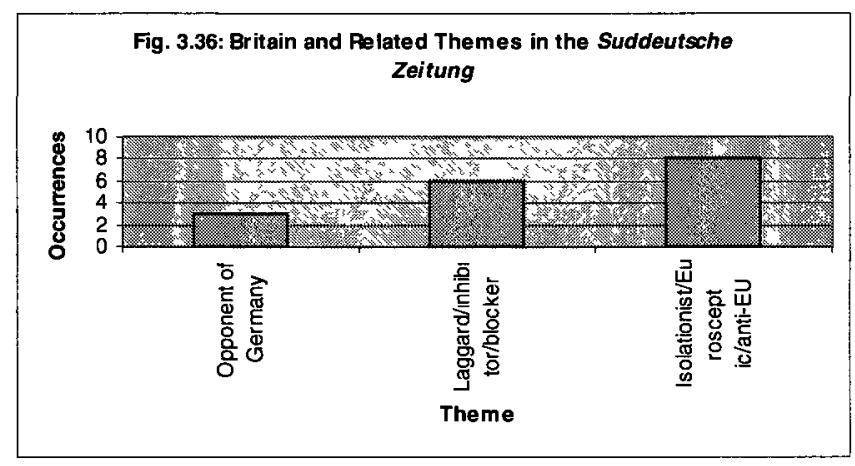

We can thus see that the newspaper followed the trend of most of the German press examined in this chapter, in that it primarily portrayed the British as Eurosceptic and antiEU or as laggards and inhibitors in the integration process. As it had done in the past, the Süddeutsche Zeitung was generally consistent in portraying these themes in a negative light. While articles coded as neutral generally reported on summit happenings in June 2004, and switched focus to the British referendum and upcoming EU presidency in May-June 2005, both neutral-negative and negative articles portrayed the British in terms of the themes mentioned above.

While there were no positive or neutral-positive articles run for this focal point, there were indications that the Süddeutsche Zeitung's attitudes towards Britain were related to how pro-European Britain acted. In both of the time periods that make up this focal point, neutral-negative articles in the newspaper painted Britain as either a worrisome or tiresome anti-EU force. One article from the June 2004 summit described a hypothetical future EU and referred to the British as naysayers: 
Inside would be the alliance for a better and "ever closer union." The naysayers, however, would stand outside the door. British, Danes, and Poles would have to organize their relationship with Brussels in a manner similar to what the Norwegians do now. ${ }^{220}$

Articles from May-June 2005 tended to discuss fears that the British would cancel their referendum on the EU constitutional treaty, thereby killing the constitution, or otherwise indicated that the British were inhibitors of the European integration project:

To make Europe palatable to the British and to persuade them to agree to a referendum on the constitution is about as difficult as selling shampoo to the bald... On the theme of Europe, the islanders traditionally fluctuate between rejection and fatalistic pragmatism. ${ }^{221}$

Articles coded as pure negative were also consistent in portraying the British as antiEuropean, although the particular focus of these varied, and not many referred to the British referendum. One particularly negative article referred to the upcoming British presidency:

Europe has no constitution. Europe may soon have no household. Europe is uncertain because it doubts its future. And as if that weren't enough of a problem, the continent will soon be controlled by a country that is something like the pariah of Europe- Great Britain. ${ }^{222}$

In concluding our considerations of the Süddeutsche Zeitung, we can say with relative certainty that the newspaper follows the tendency of other German newspapers examined here in that its pro-integration position affects its reporting on Britain; the

\footnotetext{
220 “Alles oder nichts," Süddeutsche Zeitung, June 21, 2004. German: Drinnen wären die, die mitmachen wollen bei einer besseren und "immer engeren Union". Die Neinsager jedoch, sie stünden draußen vor der Tür. Briten, Dänen oder Polen müssten ihr Verhältnis zu Brüssel ähnlich organisieren wie derzeit die Norweger.

221 "Douglas Alexander Britischer Europa-Minister in schwieriger Mission," Süddeutsche Zeitung, May 10, 2005. German: Den Briten Europa schmackhaft zu machen und sie zur Zustimmung im Referendum über die Verfassung zu überreden, ist ungefähr so schwierig, wie einem Glatzköpfigen Shampoo zu verkaufen....Beim Thema Europa schwanken die Inselbewohner traditionell zwischen Ablehnung und schicksalsergebenem Pragmatismus.

222 "Blair weckt Hoffnung," Süddeutsche Zeitung, June 30, 2005. German: Europa hat keine Verfassung. Europa wird vielleicht bald keinen Haushalt haben. Europa ist verunsichert, weil es an seiner Zukunftzweifelt. Und als wäre das nicht genug Unheil, wird der Kontinent demnächst von einem Land aus gesteuert, das so etwas ist wie das Schmuddelkind Europas - von Großbritannien.
} 
newspaper reports more positively on Britain if it is perceived to be pro-European, and more negatively if it does not. We have also seen that, in any context, there is a consistent and significant amount of negative coverage that appears regarding Britain, but the same is not true of positive coverage. Regarding this point, we have seen that the majority of both positive and negative articles are almost always subdued. Finally, the Süddeutsche Zeitung also follows the common tendency within the German press to portray Britain within an EU context as either being an inhibitor or simply anti-integration.

\section{$\underline{\text { Section Conclusions }}$}

In this section, we have been able to draw a number of conclusions about the German press and its treatment of Britain, both in a general sense as well specific. We have also been able to make a number of comparisons between the German and British press. While the final conclusion will deal with this information in a more meaningful way, it is necessary to repeat here what we have learned so far.

Regarding the German press in general, we concluded that, regardless of whether or not an EU context was being discussed, the vast majority of articles discussing Britain tended to be neutral, ranging from $2 / 3$ to $3 / 4$ of all coverage. We also found that the percentage of pure negative articles in the German press remained remarkably consistent (and relatively low) regardless of the context, and that both positive and negative reports on Britain were likely to be more subdued than blatant.

In a comparison of the attitudes of individual newspapers, we were able to refine some of these general conclusions. We found that every newspaper except Der Spiegel consistently ran a majority of neutral articles in all focal points, and that the attitudes of the weeklies were far more inconsistent from one focal point to the next than were those 
of the dailies, the latter of which were found to remain reasonably consistent in terms of relative negativity. Finally, the fluctuation in positive and negative attitudes that each individual newspaper expressed towards Britain from one focal point to the next led us to conclude that attitudes towards Britain were not predetermined, and could fluctuate based on the situation.

An examination of the attitudes of individual newspapers revealed that both of the weeklies, Der Spiegel and FOCUS, consistently portrayed Britain negatively when it acted in an anti-EU manner, allowing us to conclude that the attitudes of both newspapers regarding Britain in an EU context were dependent on how pro or anti-European Britain was perceived to be at a given time. For the Tageszeitung, we concluded that the newspaper contained negligible positive coverage of Britain, regardless of context, and moreover that the newspaper was negatively disposed towards Britain when not simply reporting on a given event. We also saw in this newspaper a tendency to run more blatantly negative articles when discussing Britain within an EU context, particularly at times of summit negotiations. Finally, like Der Spiegel and FOCUS, we found that negativity in the Tageszeitung was directly linked to anti-European moves on the part of Britain, and that the newspaper often portrayed the British as inhibitors of further European integration, or simply as anti-European. We also saw a corresponding willingness to treat Britain more positively when it acted in a more pro-European manner.

With the Berliner Zeitung, we were able to conclude that it was the most neutrally disposed newspaper towards Britain in any focal point, and further that any kind of positive or negative reporting tended to be both subdued and negligible. This newspaper did report negatively on Britain when it acted in anti-European ways, but also 
distinguished itself by running positive articles that justified these actions, thus displaying a certain objectivity with regards to European integration that was lacking in the other newspapers. Finally, we saw that the Süddeutsche Zeitung clearly followed the trend of the majority of German newspapers by reporting more positively on Britain when it was perceived to be pro-European, and more negatively when it was not. We also saw that, in any context, there was a consistent and significant amount of negative coverage that appeared regarding Britain, but there was no corresponding amount of positive coverage. Despite this, however, we saw that the majority of both positive and negative articles were almost always subdued.

With regards to comparisons drawn between the British and German press, we were first able to determine from the relative number of relevant articles in the British and German press in all focal points that the British are more interested in Germany's role in the EU than Germany is in Britain's. We also later found that the German press resorted to set themes far less frequently than its British counterpart. Both of these findings have ramifications for national image construction and identity, both of which will now be discussed in the conclusion. 


\section{Conclusions: Anglo-German Press Attitudes in the Field of European Integration}

In concluding this thesis, it is necessary first of all to reiterate what the initial intent was. Recalling the Introduction, the underlying question that guided my work was "how have the British and German presses each portrayed the role of the other country in the European integration project?" By examining press attitudes as the primary means of seeking an answer to this question, my work aimed to do several things:

- First, this thesis aimed to test a number of currently existing assumptions about British press attitudes regarding Germany, particularly within an EU context, but also in more general terms. Specifically at issue was the notion among scholars that the British press is generally negatively disposed towards Germany, and that the Germans-as-Nazis stereotype continues to loom large. Beyond simply testing existing assumptions, the use of a 5-point coding methodology for article coding was intended to show the degree of negative (or positive) reporting, thus providing a more nuanced understanding of British press attitudes than currently exists.

- Second, this thesis aimed to discover the nature of German press attitudes regarding Britain, both within and outside of an EU context. Although much has been written regarding British attitudes towards Germany, very little has been written so far from the opposing side, and this worked aimed to fill this hole in the scholarship by allowing the two to be compared.

- Third, by examining newspaper articles, this work aimed to act as a survey of attitudes regarding European integration within the public sphere, as opposed to 
the more often examined political sphere, thus allowing us to claim the existence of either parallel or diverging narratives.

- Finally, by examining the attitudes and themes that emerged in individual newspapers over time, this thesis aimed to observe the construction and maintenance of national images in Britain and Germany as they pertained to the European integration process, which, based on a constructivist approach, would ultimately provide us with insight into the shaping of national attitudes in both countries.

With regards to the first objective, my thesis has largely been able to confirm the general truth of previously held-assumptions regarding the British press and Germany, although my findings do provide some important qualifications to these. By examining attitudes towards Germany in three EU focal points as well as the test case, I have shown as a general rule that the majority of British press coverage concerning Germany is neutral, followed by a significant percentage of negative coverage (ranging from $19 \%$ to $44 \%$ ), and finally a negligible amount of positive coverage (less than 10\%). Although this reasonably large percentage of negative coverage does confirm a tendency towards negativity in the British press, it is important to note that negative coverage was never in the majority, and therefore to speak of a generally negative disposition towards Germany is somewhat misleading. My findings show that it is actually more accurate to say that non-neutral coverage of Germany in the British press is more likely to be negative than positive. 
On a similar note, although we saw a number of references made to Nazi

Germany within an EU context, thus proving the continued existence of this stereotype in the British press, this type of imagery was far from abundant, providing further qualification to previous assumptions. Finally, my use of a 5-point coding methodology has shown that negative reporting in the British press is most often subdued, manifesting itself in secondhand reports or general undercurrents rather than in blatant, editorial statements. Taking this together with the previous qualifications provides us with a somewhat different view of reporting on Germany. Instead of a hostile, anti-German press corps, we are rather presented with the image of a suspicious yet disciplined and cautious group.

With regards to the second aim, this thesis has provided important information on German press attitudes regarding Britain, which is an area where little research has been conducted thus far. Further, comparison of these findings with those from the British press has yielded some interesting results. First, my findings from all four focal points indicate that German press treatment of Britain is marked by a high percentage of neutral articles, ranging from $2 / 3$ to $3 / 4$ overall, making the German press generally more neutrally disposed towards Britain than vice versa. Second, the German press shows a greater fluctuation in its positive attitudes than the British press, ranging from no coverage to as high as $18 \%$ for the Amsterdam focal point, which is twice the value of the highest positive value in British coverage. Conversely, negative coverage of Britain tends to be more consistent, especially with regards to those articles coded as pure negative. On this last point, it is interesting to note that, in terms of overall attitudes, the German press on occasion showed the capacity to display the same level of negativity towards Britain 
that the British press could display towards Germany, although overall the British press was the more negatively disposed of the two. Finally, as was the case with the British press, my 5-point coding scale demonstrated that both positive and negative reporting tended to be subdued rather than blatant.

With specific reference to an EU context, there was no indication within the German press that set trends in attitudes existed, and these tended to fluctuate significantly from one focal point to the next. By comparison, attitudes in the British press tended to be similar regardless of the focal point, suggesting a similar view independent of context. Finally, within the German press, there was ample evidence to suggest that a given newspaper's position on European integration did affect its coverage of Britain, while this was generally not obvious among the newspapers of the British press.

On the third point, this thesis as a whole can serve as a survey of public-sphere attitudes concerning Britain and Germany in the integration process. As mentioned previously, the majority of works that concern Britain, Germany, and European integration focus on the political realm, and generally tell a story of cordial relations and cooperation. By examining press attitudes in this thesis, we have found that a secondary, less savory narrative exists. We have seen that each country, while running a majority of neutral articles, tends to favour negative reporting rather than positive when discussing the other's actions in the integration process, although there are differing reasons for this. Within the British press, Germany is often portrayed as a sinister and powerful force that operates in conjunction with France in order to further its own pro-European agenda, while in the German press, Britain is portrayed (albeit with less frequency) as an 
awkward partner in European integration, alternating between either blocking European initiatives or rejecting the whole process. These findings lead directly into the fourth point, which is contained in its own section and discusses the implications of these portrayals with regards to national image construction, the shaping of national attitudes, and identity.

Implications for Image Construction and Identity

My examination of recurring themes in the newspapers of both the British and German press has important implications for national image construction in both countries within the European integration process, which goes beyond the press itself and has ramifications for both national attitudes and identity formation. Going back to the Introduction, we recall that newspaper readership is high in both Britain and Germany, and further that this medium is one of the most common ways that British citizens get their information on the EU. Subscribing to the view that an individual's perceptions can be influenced by what he or she reads, and using the constructivist notion that repeated images and themes can over time become part of a nation's psyche, it is clear that the press in both Britain and Germany is engaged in continually constructing and maintaining a national image of the other in coverage of European integration.

Within the British press, we have seen that the theme that most often emerges, even among Europhile publications, is the image of Germany as a vaguely sinister and powerful entity, allied with France and pushing its own pro-European agenda despite the wishes of others. The fact that this theme repeatedly appears with such frequency across most of the newspapers under examination suggests that this is how the British public generally views Germany within European integration, and that the British press is 
engaged in actively maintaining this image. With regards to the first point, Grix and Lacroix have noted that the media tends to rely on easily recognizable traits or stereotypes when reporting on a given country, in order to simplify the information relay process. ${ }^{223}$ Based on this, we can infer from its repeated use that this sinister image of Germany within the European integration process finds resonance within the British public, and we are thereby provided with important information regarding British attitudes towards Germany in this process. On the other side of the equation, the repeated emphasis of Britain as a blocker or opponent of European integration within the German press indicates that this is the attitude prevalent among the German public within this context.

National images and attitudes are of course important in the construction of identity, and the findings in this thesis shed some light here as well. It is generally accepted that the process of identity construction, whether personal or national, is carried out by means of negative comparison against an entity known as the "Other," which serves as a reference point against which we can measure our own qualities. As Rainer Emig has noted in his work Stereotypes in Contemporary Anglo-German Relations, the process of identity construction involves both distrust of the foreign elements of the Other, but also admiration when the Other accepts, admires, or emulates the virtues that we associate with ourselves. ${ }^{224}$ What is perceived as negative in the Other is often qualities that a culture perceives as negative and threatening in itself. ${ }^{225}$ Emig has also

\footnotetext{
${ }^{223}$ Jonathan Grix and Chantal Lacroix, "Constructing Germany's Image in the British Press: An Empirical Analysis of Stereotypical Reporting on Germany," Journal of Contemporary German Studies 14, no. 3 (2006): 376.

${ }^{224}$ Rainer Emig, Stereotypes in Contemporary Anglo-German Relations (New York: St. Martin's Press, 2000), 3-6.

${ }^{225}$ Emig, 8.
} 
noted that identity construction makes use of stereotypes, because "in an environment that is characterized by ever-increasing complexity and multiplicity...established stereotypes offer a security blanket to which one can retreat from complexity."226

Given that our considerations of national image formation and attitudes have provided sufficient evidence of stereotyping of the Other in both the British and German press, the findings in this thesis also show:

The British press is actively engaged in constructing Germany as a threatening European Other as a means of affirming it own sovereign identity,

and

The German press is continuously reaffirming its own integrated European identity by casting Britain as an anti-European Other.

Both of these findings generally support what the current scholarship says with reference to each country and its identity regarding European integration, although this has generally not been undertaken with a specific country acting as the Other, as has been done here. Regarding the first point, we have seen that the most common theme that emerges in British newspapers is that of the Franco-German partnership, and that this partnership is often spoken of in both subdued and blatantly threatening tones. The pairing of Germany with France is important, as it serves to represent an invasive European (not simply German) Other that challenges to British identity through its attempts at what is often referred to as "federalism". What is implied by this term is a loss of sovereignty, which is central to British identity.

\footnotetext{
${ }^{226}$ Emig, 4.
} 
Jeremy Rand notes that the strong attachment that the British have to their sovereignty is a function of their peculiar history. As an island nation, Britain has not experienced a successful invasion from the mainland since 1066, which has led to a high degree of political stability and constitutional continuity that contrasts sharply with the experiences of the European continent. ${ }^{227}$ Thus, British identity is decidedly antiEuropean, and is reinforced in the press by continually casting the European Other in a negative light. Recalling the findings in this thesis, it is thus no surprise to find that British newspapers comment most negatively on Germany (and France) when discussing the EU constitution, which easily had the most implications for British sovereignty of any of the topics examined here. In this focal point, and in others, we have seen both subdued and blatant attacks on the Franco-German couple, with frequent references to economic and political incompetence, which are the very areas that European integration affects most. The unspoken (and sometimes spoken) implication is thus that the British way of doing things is superior.

On the second point, we have seen that German newspapers routinely refer to the British negatively as inhibitors of European integration, or simply as Eurosceptic or antiEU. We have also noted a corresponding tendency within the German press to be positively disposed towards Britain when it acts in a more pro-European way. This shows us the centrality of European integration in German national identity by allowing us to directly observe how the British Other is portrayed when it either opposes or emulates the values that make up this identity. If we accept the assertion that positive reporting in the German press reflects the county's values and negative reporting reflects its own fears,

\footnotetext{
${ }^{227}$ Jeremy Rand, "British Identity and European Integration," in The European Union and Britain: Debating the Challenges Ahead, ed. Vassiliki Koutrakou and Lucie Emerson, (New York: St. Martin's Press, 2000), 25-26.
} 
then we can see that what Germany fears is disconnection from Europe. As in the British case, this is a result of the country's peculiar experiences, and as once again explained by Sanna Inthorn, "Europe offered the chance to ease to burden of the national socialist past and to identify with a concept of European values and peace."228 It is therefore clear that the German press, like the British press, is actively engaged in national identity construction within the context of European integration.

As one interesting final point, this thesis provides some considerations for identity that extend beyond an EU context, the most important of which concerns the position of one country in the opposing country's national identity. There is ample evidence provided in the body of this thesis that allows us to conclude that Germany factors higher as an Other in British national identity than Britain factors for Germany, a fact which has been previously assumed but not confirmed. The findings that lead us to this conclusion are the quantities of relevant press coverage in each country and both the quantity and nature of the recurring themes and emphases.

In terms of quantities, we have seen how the number of German-related articles in the British press is much higher than in the opposite case, indicating a greater interest, and we have also see how there is a greater number of stereotypes utilized in the British press as well. Most of these stereotypes, unlike those found in the German press, do not appear to have been created with an EU context, but rather seem to have been preexisting and applied to Germany within this context. This is supported by the evidence we have seen that British press negativity and positivity is less dependent on context than in the German press. Additionally, Germany in the British press is frequently cast as a real threat, and often appears as an opponent in press coverage. Conversely, Germany

\footnotetext{
${ }^{228}$ Sanna Inthorn, German Media and National identity (New York: Cambria Press, 2007), 34.
} 
more often portrays Britain as a nuisance rather than a genuine threat, and very few articles cast Britain as a direct opponent. All of these findings suggest that Germany factors larger as an Other in British national identity than in the reverse case, which tends to confirm the generally existing notion of a British "obsession" with Germany.

\section{$\underline{\text { Further Considerations }}$}

Outside of the findings concerning the major objectives of this thesis, a number of additional interesting points have been uncovered in this work, and these are briefly considered here. First, we observed a number of shifts in the final chapter which discredited a number of earlier hypotheses. In the British press, we saw an increase in negativity in general, particularly in the Daily Mail, which reverted back to the same level of negativity that it displayed in the test case, and the Times, which broke its tendency towards neutral-negative reporting in favour of more blatant attitudes. In the German press, we saw negativity increase in both FOCUS and the Süddeutsche Zeitung, which had been hypothesized previously to be more positively disposed towards Britain within an EU context. All of these can likely be explained by the high importance assigned to the EU constitution, the country's stance on European integration, and the actions of the other country. As previously mentioned, the spike in negativity within the British press at this time is likely related to the attachment of the country to its national sovereignty. The fact that negativity shifts were observed in newspapers taking a Eurosceptic position, and therefore champions of British sovereignty, adds particular weight to this assertion. In the German press, the increased negativity can be attributed to anti-European actions taken by the British, which conflicted with the generally proEuropean stance of the newspapers in question. 
Second, the evidence uncovered seems to indicate that British Europhile publications are not as predictable in their treatment of the opposing country as those in Germany. We have seen that, while British Eurosceptic newspapers generally behave as expected, Europhile newspapers often carry the same negative themes as these when discussing Germany. This would seem to indicate that a newspaper's position on integration is less important than perceptions regarding Germany. Speaking further of individual newspapers, we have seen in both press groups that the attitudes of the broadsheets tend to remain more consistent than those of the weeklies. This is likely due to the more limited space afforded to a once-weekly publication, which must necessarily give voice to only the most topical issues and attitudes, which may shift significantly from one week to the next.

Finally, there does not seem to be any indication in the findings in this thesis that the attitudes expressed in one press group are related to those in the other. Recalling the Amsterdam and Nice focal points, we found German attitudes to be more positive for Amsterdam while British attitudes were more negative, with the opposite occurring for coverage of Nice. There is, however, evidence to suggest that coverage in the German press reflects the political relations between the two countries more closely than coverage in the British press does. Excluding the test cases, there is an increasing tendency towards negativity in the German press, beginning with the Amsterdam summit and proceeding to the rejection of the EU constitution. Recall that British Labour had taken power shortly before Amsterdam, and that at that time the British prime minister, Tony Blair, shared a close friendship with the German chancellor, Gerhard Schröder. Further recall that this relationship deteriorated over time, eventually reaching rock bottom at the time of the EU 
Constitution, and this observation becomes more compelling. Unfortunately, however, there is no room to develop this argument here, and it must therefore wait for examination by future scholars.

\section{Closing Remarks}

In closing this thesis, we have found that the answer to the initial question,

"How have the British and German presses each portrayed the role of the other country in the European integration project?"'

can be answered,

"In a way that tends to be more negative than positive, and is a function of each country's position on the project in general as well as their perception of the other within it."

This answer of course condenses a great deal of information, but this does not diminish its overall truth. Admittedly, there are areas within this thesis where there is room for improvement, but I believe that the research is sound and that this work may serve at least as a reference or standard to any wishing to bring more clarity to a generally unexplored area. In any case, I leave it to future scholars to further elaborate and improve upon the work that I have begun here, with the eventual hope of allowing more light to be shed on Anglo-German press attitudes in the field of European integration. 
Bibliography

Primary Sources

The Dail Mail \& The Mail on Sunday (79 articles), 1990, 2000-2001, 2004-2005.

The Times \& The Sunday Times (274 articles), 1990, 1997, 2000-2001, 2004-2005.

The Independent (211 articles), 1990, 1997, 2000-2001, 2004-2005.

The Guardian (208 articles), 1990, 1997, 2000-2001, 2004-2005.

The Economist (56 articles), 1990, 1997, 2000-2001, 2004-2005.

Der Spiegel (27 articles) 1997, 2000-2001, 2004-2005.

FOCUS (26 articles) 1997, 2000-2001, 2004-2005.

Die Tageszeitung (107 articles) 1997, 2000-2001, 2004-2005.

Die Berliner Zeitung (116 articles) 2000-2001, 2004-2005.

Die Süddeutsche Zeitung (180 articles), 1997, 2000-2001, 2004-2005.

House of Commons. Report by the Comptroller and Auditor General HC 939: The 2001 Outbreak of Food and Mouth Disease. London, England: House of Commons, 2002.

"Row over spoof Hitler euro advert." BBC News: World Edition.

http://news.bbc.co.uk/2/hi/uk_news/politics/2087261.stm (accessed October 15, 2009).

"The Press in Germany." BBC News Europe.

http://news.bbc.co.uk/2/hi/europe/3414139.stm (accessed August 1, 2010).

\section{$\underline{\text { References }}$}

Anderson, Peter. "A Flag of Convenience? Discourse and Motivations of the Londonbased Eurosceptic Press." Journal of European Studies 20 (2004): 151-170.

Anderon, Peter. and Weymouth, Tony. Insulting the Public? The British Press and the European Union. New York: Addison Wesley Longman, 1999.

Best, Edward. "The United Kingdom: From Isolation Towards Influence?" in The Amsterdam Treaty: National Preference Formation, Interstate Bargaining, and Outcome, edited by Finn Laursen, 359-380. Odense: Odense University Press, 2002.

Beuter, Rita. "Germany: Safeguarding the EMU and the Interests of the Länder." in The Amsterdam Treaty: National Preference Formation, Interstate Bargaining, and Outcome, edited by Finn Laursen, 93-120. Odense: Odense University Press, 2002.

Crawford, Claudia. "The Relations Between Great Britain and Unified Germany." KAS International Reports 9 (2010): 94-108. 
Duff, Andrew. "Britain and Europe: The Different Relationship." in The European Union Beyond Amsterdam: New Concepts of European Integration, edited by Martin Westlake, 34-46. New York: Routledge, 1998.

Grix, Jonathan. and Lacroix, Chantal. "Constructing Germany's Image in the British Press: An Empirical Analysis of Stereotypical Reporting on Germany." Journal of Contemporary German Studies 14, no. 3 (2006): 373-392.

Grunhage, Jan. "The 1996/97 Intergovernmental Conference: A Survey of the Process." in The European Union after the Treaty of Amsterdam, edited by Jörg Monar and Wolfgang Wessels, 9-30. New York: Continuum, 2000.

Hamalainen, Pekka Kalevi. Uniting Germany: Actions and Reactions. Boulder: Westview Press, 1994.

Inthorn, Sanna. German Media and National Identity. New York: Cambria Press, 2007.

Kohl, Helmut. "Foreword." in The European Union after the Treaty of Amsterdam, edited by Jorg Monar and Wolfgang Wessels, ix-xiii. New York: Continuum, 2000.

Lee, Sabine. Victory in Europe? Britain and Germany since 1945. New York: Longman, 2001.

Major, Patrick. "Britain and Germany: A Love-Hate Relationship?" German History 26, no. 4 (2008): 457-468.

McCormick, John. Understanding the European Union: A Concise Introduction. New York: Palgrave Macmillan, 2005.

Medrano, Juan Diez. Framing Europe: Attitudes to European Integration in Germany, Spain, and the United Kingdom. Oxford: Princeton University Press, 2003.

Monar, Jörg. "Continuing and Building on Amsterdam: The Reforms of the Treaty of Nice," in The European Union after the Treaty of Amsterdam, edited by Jörg Monar and Wolfgang Wessels, 321-344. New York: Continuum, 2000.

Needle, Clive. "Foreword," in The European Union and Britain: Debating the Challenges Ahead, edited by Vassiliki Koutrakou and Lucie Emerson, ix-xii. New York: St. Martin's Press, 2000.

Ramsden, John. Don't Mention the War: The British and the Germans since 1890. Great Britain: Little, Brown, 2006.

Rand, Jeremy. "British Identity and European Integration," in The European Union and Britain: Debating the Challenges Ahead, edited by Vassiliki Koutrakou and Lucie Emerson, 24-43. New York: St. Martin's Press, 2000. 
Temple, Mick. The British Press. New York: Open University Press, 2008.

Woods, Abigail. A Manufactured Plague? The History of Foot and Mouth Disease in Britain. London: Earthscan, 2004. 